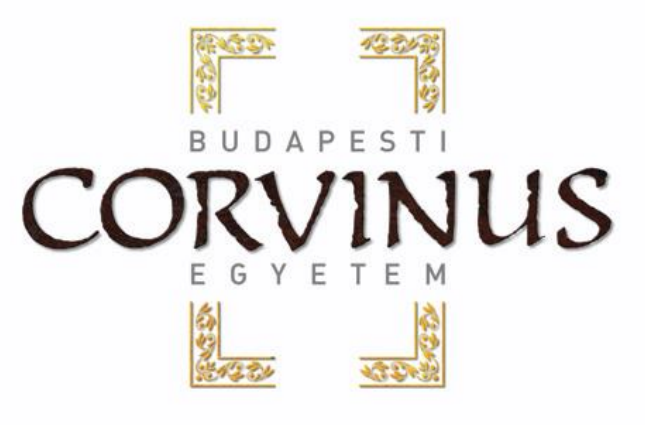

\title{
Élelmiszerromálást okozó Yarrowia csoport biodiverzitása különböző élelmiszerekben
}

\author{
Doktori értekezés
}

\author{
NAGY EDINA SZANDRA \\ Témavezető: Dr. Péter Gábor \\ tudományos fómunkatárs
}

Budapest

2015 


\section{A doktori iskola}

megnevezése: Élelmiszertudományi Doktori Iskola

tudományága: Élelmiszertudományok

vezetője: $\quad$ Dr. Felföldi József, egyetemi tanár, $\mathrm{PhD}$

Budapesti Corvinus Egyetem, Élelmiszertudományi Kar Fizika-Automatika Tanszék

Témavezető: $\quad$ Dr. Péter Gábor, tudományos főmunkatárs, $\mathrm{PhD}$ Budapesti Corvinus Egyetem, Élelmiszertudományi Kar Mezőgazdasági és Ipari Mikroorganizmusok Nemzeti Gyüjteménye

A jelölt a Budapesti Corvinus Egyetem Doktori Szabályzatában elöírt valamennyi feltételnek eleget tett, a mühelyvita során elhangzott észrevételeket és javaslatokat az értekezés átdolgozásakor figyelembe vette, ezért az értekezés nyilvános vitára bocsátható. 
A Budapesti Corvinus Egyetem Élettudományi Területi Doktori Tanácsának 2015. június 9.-i határozatában a nyilvános vita lefolytatására az alábbi bíráló Bizottságot jelölte ki:

BÍRÁLÓ BIZOTTSÁG:

Elnöke

Mohácsiné Farkas Csilla, PhD

\author{
Tagjai \\ Halász Anna, DSc \\ Beczner Judit, CSc \\ Kiskó Gabriella, PhD \\ Belák Ágnes, $\mathrm{PhD}$
}

Opponensek

Dobolyi Csaba, CSc

Sipiczki Mátyás, CSc

Titkár

Styevkó Gabriella 
DOI: 10.14267/phd.2015033 


\section{TARTALOMJEGYZÉK}

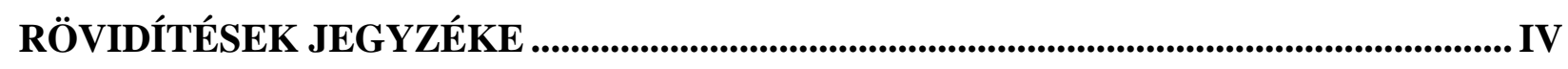

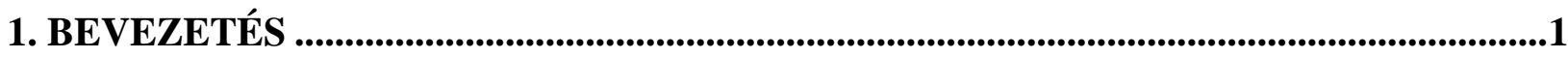

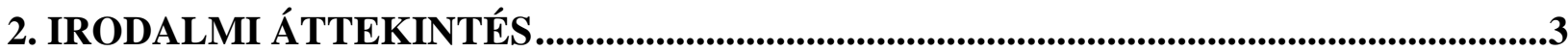

2.1. A YARROWIA LIPOLYTICA ÉS ROKON FAJAI TERMÉSZETES ELÖFORDULÁSA ÉS SZEREPE

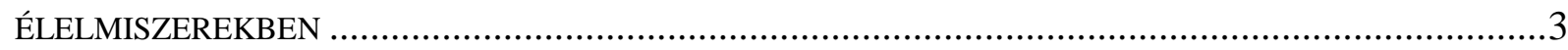

2.1.1. A Yarrowia csoport tagjainak elöfordulása és szerepe tejtermékekben........................4

2.1.2. A Yarrowia csoport tagjainak elöfordulása és szerepe húsokban és

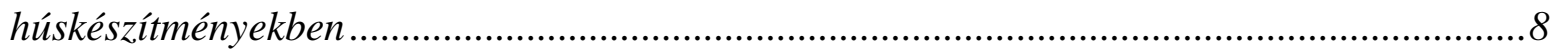

2.1.3. A Yarrowia csoport tagjainak elöfordulása és szerepe egyéb élelmiszerekben ..........11

2.1.4. A Yarrowia csoport tagjainak elöfordulása élelmiszereken kivül ...............................11

2.2. A YARROWIA CSOPORT TAXONÓMIÁJA ÉS DIVERZITÁSA ........................................................ 12

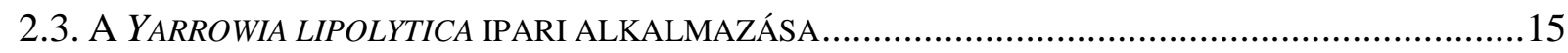

2.4. AZ ÉLESZTŐGOMBÁK RENDSZERTANI AZONOSÍTÁSÁNAK MÓDSZEREI..................................19

2.4.1. Morfológiai és fiziológiai tulajdonságokon alapuló hagyományos azonosítás...........19

2.4.2. Molekuláris módszereken alapuló azonosítás .........................................................21

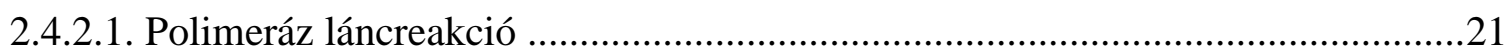

2.4.2.2. Tipizálásra alkalmas PCR alapú technikák ....................................................22

2.4.2.3. Azonosításra alkalmas PCR alapú technikák ...................................................23

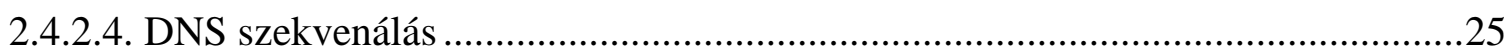

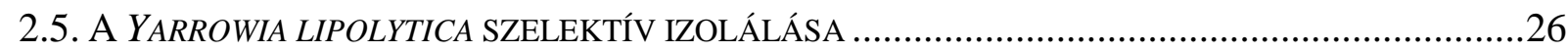

2.6. A YARROWIA LIPOLYTICA FENOTÍPUSOS ELKÜLÖNÍTÉSI LEHETÖSÉGEI A YARROWIA CSOPORT

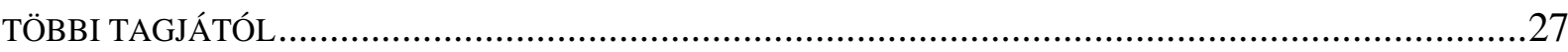

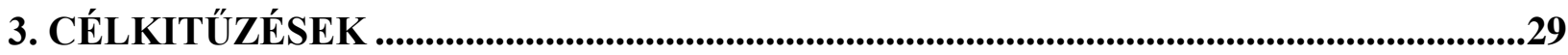

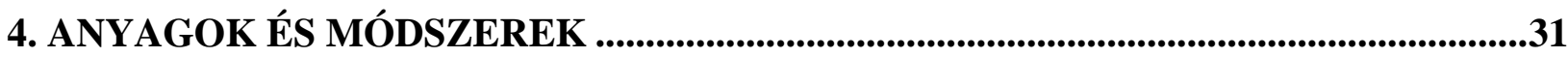

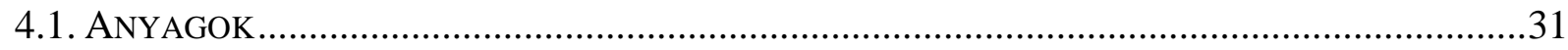

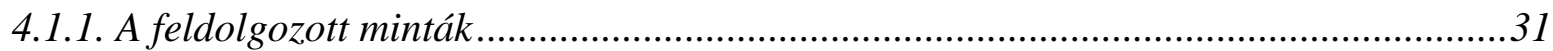

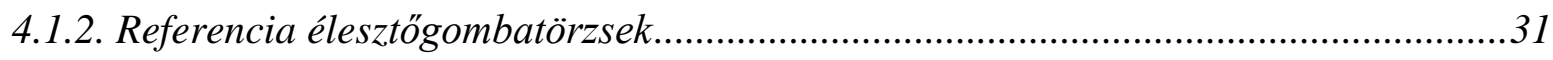

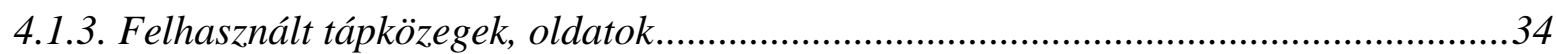

4.1.4. Molekuláris vizsgálatokhoz felhasznált anyagok, oldatok, oligonukleotid primerek..36

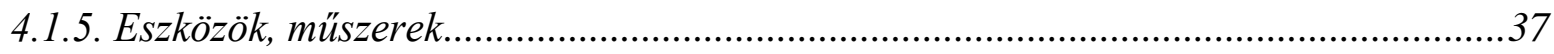

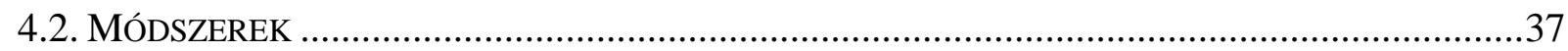

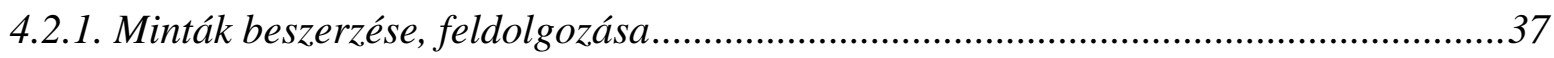

4.2.2. Szelektív módszer keresése Yarrowia csoportba tartozó törzsek izolálásához .............38

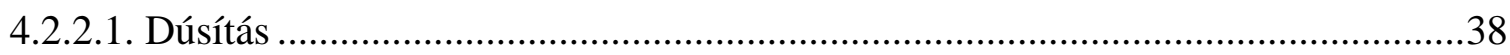

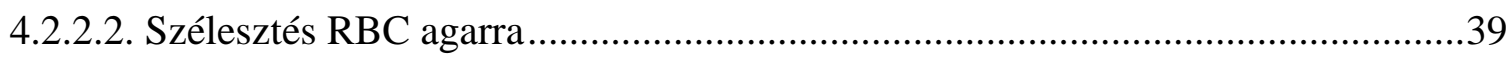

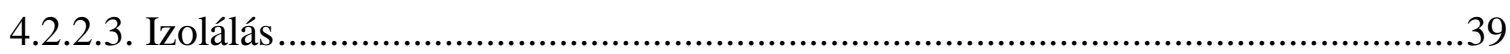

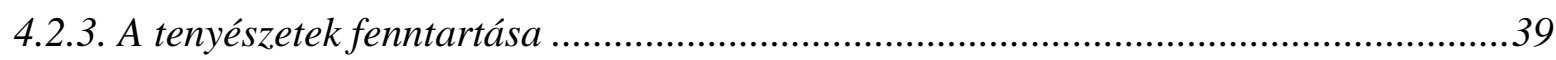

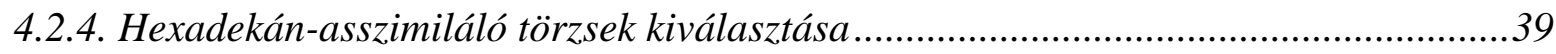


4.2.5. A Yarrowia-dúsító tápleves módosítása a nagyobb hatékonyság érdekében ............. 40

4.2.6. A Yarrowia csoportba tartozó törzsek elkülönítése fiziológiai tesztekkel .................. 40

4.2.7. A Yarrowia csoportba tartozó törzsek csoportosítása MP-PCR módszerrel ............. 42

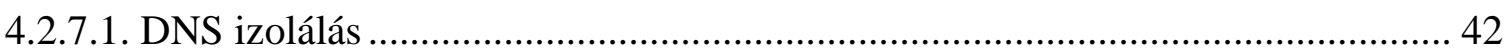

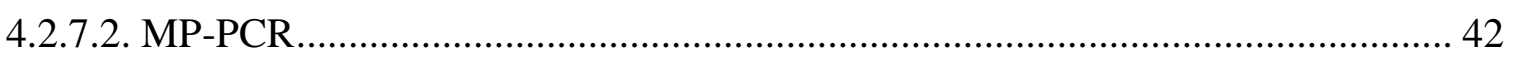

4.2.7.3. Gélelektroforézis és a kapott mintázat értékelése.......................................... 42

4.2.8. A Yarrowia csoport tagjainak fajszintü azonositása molekuláris módszerrel............ 43

4.2.8.1. A 26S rRNS-t kódoló gén D1/D2 régiójának megsokszorozásához használt PCR

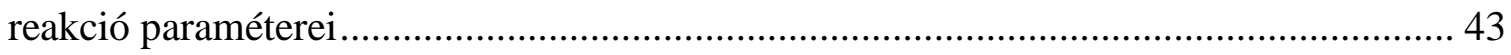

4.2.8.2. Az ITS régióinak megsokszorozásához használt PCR reakció paraméterei ........ 43

4.2.9. A Yarrowia csoport fajainak egymástól való elkülönítésének lehetöségei fiziológiai

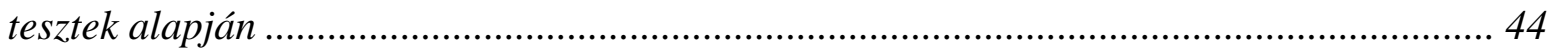
4.2.10. A Yarrowia csoport tagjainak az élelmiszerek romlásához potenciálisan hozzájáruló

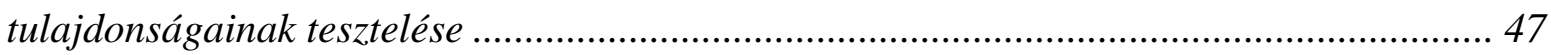

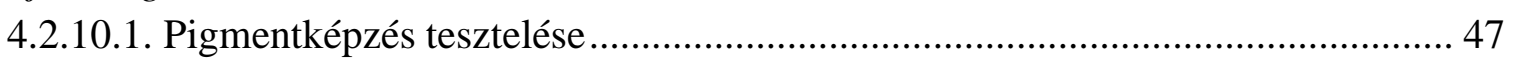

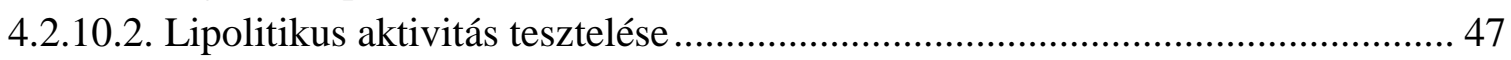

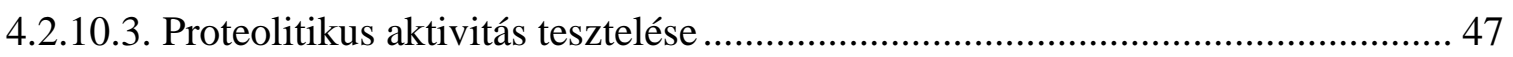

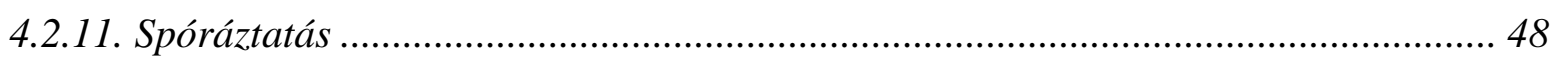

5. EREDMÉNYEK ÉS ÉRTÉKELÉSÜK ............................................................................... 49

5.1. AZ IZOLÁLÁSI MÓDSZER HATÉKONYSÁGA, AZ IZOLÁLT ÉLESZTŐGOMBATÖRZSEK............... 49

5.1.1. A McIlvaine puffer oldatot tartalmazó dúsító tápleves felhasználásával izolált törzsek

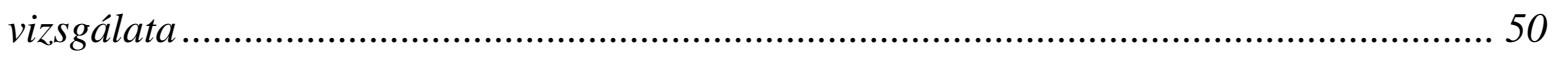

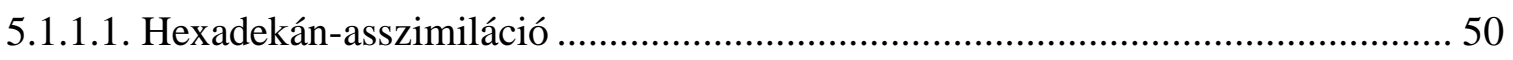

5.1.1.2. A Yarrowia csoportba tartozó törzsek elkülönítése fiziológiai tesztekkel .......... 52

5.1.2. A foszfát puffer oldatot tartalmazó dúsító tápleves felhasználásával izolált törzsek

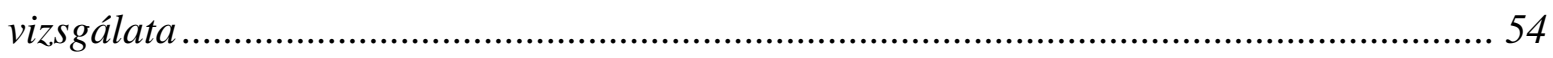

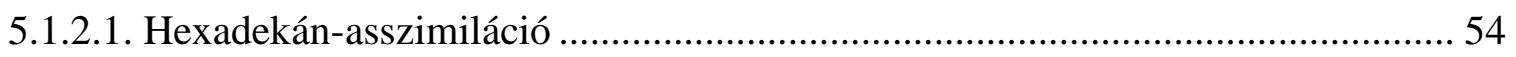

5.1.2.2. A Yarrowia csoportba tartozó törzsek elkülönítése fiziológiai tesztekkel .......... 54

5.1.3. A dúsító táplevesek hatékonyságának összehasonlítása ........................................... 54

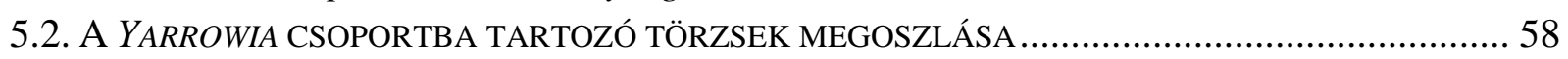

5.3. A YARROWIA CSOPORTBA TARTOZÓ TÖRZSEK CSOPORTOSÍTÁSA MP-PCR MÓDSZERREL .... 61

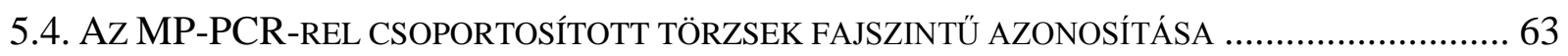

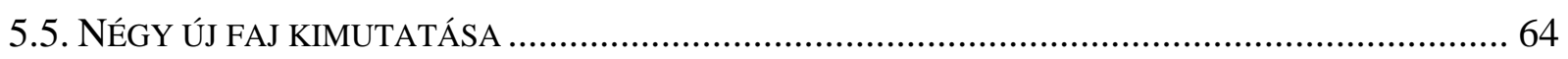

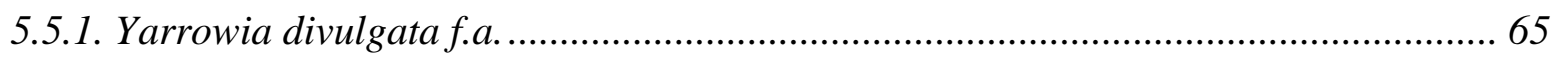

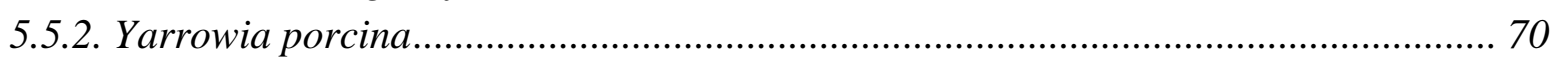

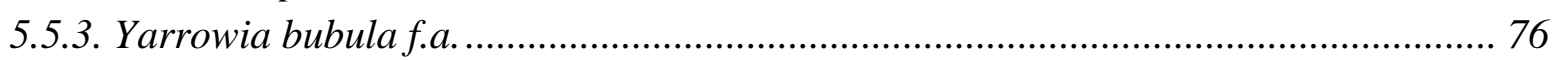

5.6. A YARROWIA CSOPORTBA TARTOZÓ FAJOK MEGOSZLÁSA A VIZSGÁLT ÉLELMISZEREKBEN .. 78

5.7. HATÁROZÓ KULCS A YARROWIA CSOPORT TAGJAINAK EGYMÁSTÓL VALÓ ELKÜLÖNÍTÉSÉHEZ

5.8. A YARROWIA CSOPORT TAGJAINAK AZ ÉLELMISZEREK ROMLÁSÁHOZ ESETLEGESEN

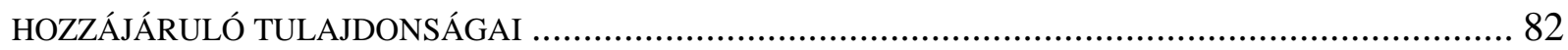

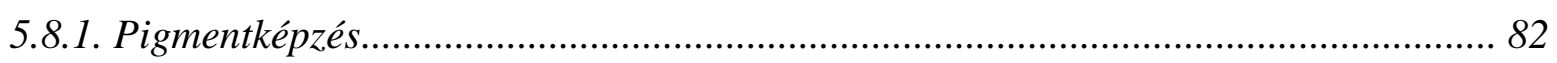

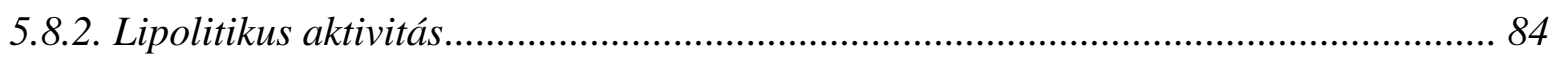

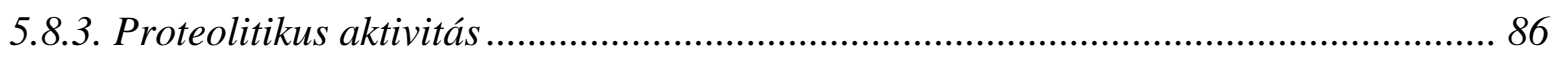


5.9. A YARROWIA CSOPORT TAGJAINAK SPORULÁCIÓJA.

5.10. AZ IZOLÁLT, NEM A YARROWIA CSOPORTBA SOROLT, HEXADEKÁN-ASSZIMILÁLÓ TÖRZSEK FAJSZINTÜ AZONOSÍTÁSA

5.11. HEXADEKÁN-POZITÍV ÉLESZTŐGOMBATÖRZSEK MEGOSZLÁSA A VIZSGÁLT ÉLELMISZEREKBEN

5.12. AZ ÚJONNAN KIDOLGOZOTT MÓDSZERREL IZOLÁLT ÉLESZTŐGOMBATÖRZSEK MEGOSZLÁSA A VIZSGÁLT ÉLELMISZEREKBEN..... .98

5.13. ÚJ TUDOMÁNYOS EREDMÉNYEK 104

6. KÖVETKEZTETÉSEK ÉS JAVASLATOK 105

7. ÖSSZEFOGLALÁS 107

8. SUMMARY 113

9. IRODALOMJEGYZÉK 119

MELLÉKLETEK. 143

M1. FELHASZNÁLT TÁPKÖZEGEK, OLDATOK ÖSSZETÉTELE. 143

M2 ÁBRAJEGYZÉK 154

M3 TÁBLÁZATJEGYZÉK 159

PUBLIKÁCIÓS LISTA 161

KÖSZÖNETNYILVÁNÍTÁS. 163 


\section{RÖVIDÍTÉSEK JEGYZÉKE}

AFLP: amplified fragment lenght polymorphism - felszaporított fragmentek hosszának sokfélesége

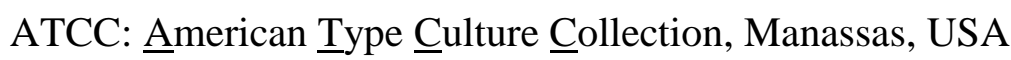

bp: bázispár

Blast: Basic Local Allignment Search Tool - nukleotidszekvenciák adatbázisban található szekvenciákkal való összehasonlítására szolgáló program

C.: Candida

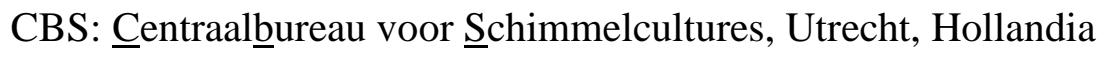

D. hansenii: Debaryomyces hansenii

D1/D2: a 26S rRNS-t kódoló gén élesztőgombák fajszintű azonosításhoz használt egyik régiója

DBB: Diazonium $\underline{B}$ lue $\underline{B}$ - aszkomikóta és bazidiomikóta élesztőgombák elkülönítésére alkalmas teszt

f. a. : forma asexualis - ivartalan alak

ITS: internal trancsribed spacer - riboszóma gének közti átíródó, de nem kódoló DNS szakasz, gombák fajszintű azonosításhoz használt egyik régió

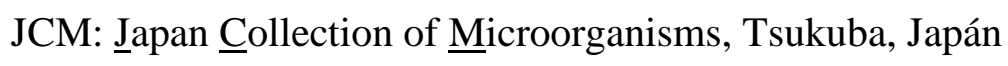

LSU rRNS gén: large șubunit rRNA gene- az rRNS nagy alegységét kódoló DNS szakasz MIMNG: Mezőgazdasági és Ipari Mikroorganizmusok Nemzeti Gyüjteménye, Budapest

MP-PCR: microsatellite-primed polymerase chain reaction - mikroszatellit primerrel végzett polimeráz láncreakció

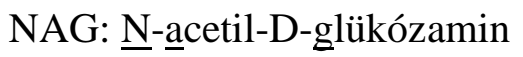

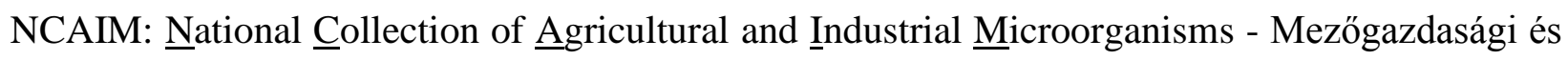
Ipari Mikroorganizmusok Nemzeti Gyüjteménye, Budapest

nom. nud.: nnomen nudum - „,csupasz név”, olyan új taxon név, ami leírás vagy diagnózis, illetve leírásra vagy diagnózisra való hivatkozás nélkül került publikálásra

NRRL: National Center for Agricultural Utilization Research, Peoria, USA

\section{P. roqueforti: Penicillium roqueforti}

PCR: polymerase chain reaction - polimeráz láncreakció

PCR-RFLP: polymerase chain reaction - restriction fragment lenght polymorphism - polimeráz láncreakció - restrikciós fragmenthossz polimorfizmus

RAPD- PCR: random amplified polymorphic DNA- polymerase chain reaction - véletlenszerüen megsokszorozott polimorf DNS polimeráz láncreakció 
rDNS: rRNS-t kódoló gén

rRNS: riboszómális RNS

S. cerevisiae: Saccharomyces cerevisiae

SSU rRNS gén: small subunit rRNA gene - az rRNS kis alegységét kódoló DNS szakasz Y: Yarrowia 
DOI: 10.14267/phd.2015033 


\section{BEVEZETÉS}

A Yarrowia lipolytica az egyik legszéleskörübben tanulmányozott, élelmiszeripari szempontból az egyik legjelentősebb élesztőgomba faj. Számos publikáció tárgyalja természetes előfordulását, pozitív és negatív szerepét különböző élelmiszerekben, elsősorban nyers húsban, tejtermékekben. Számtalan külföldi és hazai vizsgálat eredményét ismertető publikáció alapján az említett élelmiszerekben az egyik leggyakoribb élesztőgombafaj, a joghurtból izolált élesztőgombatörzsek 15\%-át teszi ki, hütött körülmények között tárolt baromfihús és -belsőségek esetében ugyanez az érték 39\%, marhahús esetében pedig egy tanulmány szerint $69 \%$.

Rendkívül erős lipolitikus és proteolitikus aktivitással, pigmenttermelö-képességgel rendelkezik. Számos esetben élelmiszerromlást okozó, vagy legalábbis romláshoz hozzájáruló élesztőgomba fajként számolnak be róla. Ezzel szemben nem hagyhatók figyelmen kívül élelmiszeripari szempontból előnyös tulajdonságai sem. Képes fontos anyagcseretermékek termelésére és azok nagy mennyiségben történő kiválasztására, ami indokolttá teszi az iparban való alkalmazását és a tanulmányozását. Egyik legfontosabb tulajdonsága, erős lipáztermelő képessége számos területen hasznosítható, az élelmiszeriparon kívül például a tisztítószer- és gyógyszeriparban is felhasználató, de akár a környezetvédelemben is fontos szerepet tölthet be. Az élelmiszeriparban a lipáz enzim termeltetésén kívül hasznosítják citromsav, karotinoidok, mannit, eritrit és aromavegyületek előállítására is.

Az utóbbi évtizedben megjelent külföldi közleményekből világossá vált, hogy a korábban hagyományos módszerekkel $Y$. lipolytica-ként azonosított törzsek egy része valójában nem $Y$. lipolytica, számos esetben más fajhoz tartozó élesztőgombákat tévesen e fajként azonosítottak. Az említett fajtól alapvető fenotípusos bélyegek alapján megbízhatóan meg nem különböztethető fajok molekuláris biológiai vizsgálatával megállapítható, hogy a Yarrowia lipolytica egy számos fajt magába foglaló komplex tagja, amely további rokon fajokkal kiegészülve a Yarrowia csoportot alkotja. Munkám kezdetekor a Yarrowia csoport az alábbi fajokat foglalta magába: $Y$. lipolytica, Y. (C.) deformans, Y. (C.) yakushimensis, Candida galli, C. phangngensis, C. oslonensis, C. alimentaria, C. hollandica, C. hispaniensis. A Yarrowia csoportba sorolt élesztőgombák száma azóta, részben munkám eredményeként kilencről tizenháromra emelkedett.

A fentiek alapján feltételezhető, hogy a korábban megjelent, élelmiszerekkel és azok romlásával, vagy ipari alkalmazással összefüggésben említett, hagyományos módszerekkel $Y$. lipolytica-ként azonosított törzsek egy része valójában nem $Y$. lipolytica, hanem a csoport más fajaihoz tartozó élesztőgomba. Így már nem említhetjük pusztán a $Y$. lipolytica-t, mint 
kiemelkedő jelentőségủ élesztőgombát, mert esetenként a csoport többi tagjának ugyanolyan nagy szerepe lehet, legyen az akár pozitív, akár negatív szerep.

A kutatásaim legföbb célja a Yarrowia csoport különbözö élelmiszerekben való faji sokféleségének megismerése volt. A Yarrowia csoportba tartozó törzsek nagy számban való begyüjtéséhez hatékony izolálásra alkalmas módszer kidolgozására volt szükség. Célul tüztem ki, hogy hatékony izolálási módszert dolgozzak ki a potenciálisan romlást okozó Yarrowia komplex csoportba tartozó élesztőgomba törzsek izolálására különböző élelmiszercsoportokból (nyers húsból, nyers tejből és tejtermékekből), majd az izolált törzsek közül fiziológiai tesztek alkalmazásával különítsem el a Yarrowia csoportba tartozókat, és molekuláris módszerrel történő csoportosításukat követően DNS szekvenciájuk alapján azonosítsam a Yarrowia csoportba tartozó fajokat, megvizsgáljam azok fenotípusos elkülönítésének lehetőségeit.

További célom volt a DNS szekvenáláson alapuló módszerrel azonosított Yarrowia csoportba tartozó élesztőgomba törzsek fajspektrumának és az izolálási forrásul szolgáló élelmiszerek körének összehasonlítása és a termék-specifikus elöfordulás vizsgálata, a kísérletek során felmerülő esetleges újabb kérdések, problémák megoldása. 


\section{IRODALMI ÁTTEKINTÉS}

\subsection{A Yarrowia lipolytica és rokon fajai természetes előfordulása és szerepe élelmiszerekben}

A Yarrowia lipolytica erős lipolitikus és proteolitikus aktivitásáról ismert (Ismail et al. 2000; Corbo et al. 2001; Gardini et al. 2006; Patrignani et al. 2011), megfelelő számára a magasabb só-, zsír- és fehérjetartalmú, laktózban gazdag környezet (Fleet 2006), ezzel összhangban elsősorban olyan élelmiszerekben fordul elö, melyekben nagy arányban található zsír és/vagy fehérje, különösen húsban és tejtermékekben (Rohm et al. 1992; Roostita and Fleet 1996; Fröhlich-Wyder 2003).

A Yarrowia lipolytica élelmiszerekben való gyakori és nagy számban való előfordulását lehetővé teszi, hogy viszonylag szélsőséges körülmények között is képes szaporodni. Praphailong és Fleet (1997) vizsgálatából az derül ki, hogy pH 5,0 értéken a Zygosaccharomyces bailii mellett a $Y$. lipolytica a legellenállóbb szorbát és benzoát tartósítószerekkel, utóbbi szaporodik akár $1000 \mathrm{mg} / \mathrm{l}$ szorbát jelenlétében is. Képes szaporodni 0,89 értékü vízaktivitásnál, $12,5 \% \mathrm{NaCl}$ tartalom vagy akár pH 2,0 érték mellett, vagy 50\% szacharóz jelenlétében. Savakkal szembeni ellenállóképessége megközelíti a Zygosaccharomyces bailii-ét, az egyik legellenállóbb élelmiszerromlást okozó élesztőgombáét (Rodriguez és Pais 2000), képes pH 10-10,5 értéken is szaporodni, így alkalitoleránsnak tekinthető (Deák 2006) és képes akár $5{ }^{\circ} \mathrm{C}$-on is szaporodni és dominánssá válni hütve tárolt baromfihúsban (Ismail et al. 2000). Guerzoni és munkatársai (1993) hütött élelmiszereket (halakat, húsokat, zöldségeket, salátákat, töltött tésztákat) vizsgáltak, a legnagyobb számban izolált élesztőgomba a $Y$. lipolytica volt, amit a Debaryomyces hansenii és a Pichia membranifaciens követett. Tanulmányukban azt a következtetést vonták le, hogy az említett élesztőgombák is jelentősen hozzájárulhatnak ezeknek a termékeknek a romlásához. Kobatake és Kurata (1983) hűtve tárolt paradicsom- és makaróni salátákból, kínai galuskából számos más élesztőgomba faj mellet Y. lipolytica törzseket is izolált. Banks és Board (1987) szintén a hütve tárolt élelmiszerekben leggyakrabban elöforduló élesztőgombák között említi a $Y$. lipolytica-t. Fagyasztott csirkehúsból izolált élesztőgombák között 18\%-kal a második leggyakoribb faj és izolálható fagyasztott halból is (Diriye et al. 1993). Besugárzott baromfihús mintákból is nagy számban izolálták (Sinigaglia et al. 1994).

A $Y$. lipolytica-t sok esetben összefüggésbe hozták élelmiszerek érésével és/vagy romlásával. Az 1. ábrán látható összefoglalva az izolálási forrásul szolgáló élelmiszerek köre, valamint a $Y$. lipolytica rájuk kifejtett előnyös vagy hátrányos hatásai (Groenewald et al. 2013). Sajtok és fermentált húskészítmények érleléséhez starter kultúraként való esetleges 
alkalmazásakor döntő fontosságú, hogy az adott élelmiszerre képes legyen kifejteni előnyös hatásait, miközben az esetleges negatív hatásait gátolják.

Groenewald és munkatársai (2013) rendkívül alapos áttekintő közleményükben megállapították, hogy a $Y$. lipolytica anyagcsere-termékeinek tejtermékekben van legnagyobb szerepe, azon belül is sajtokban, amit a fermentált húskészítmények követnek, majd olyan élelmiszerek zárják a sort, melyekből csak alkalomszerúen tudták izolálni, mint például üdítőitalok, bor, must, almabor, gyümölcsök, zöldségek, majonéz, salátaöntetek, saláták, hütött és fagyasztott, feldolgozott élelmiszerek.

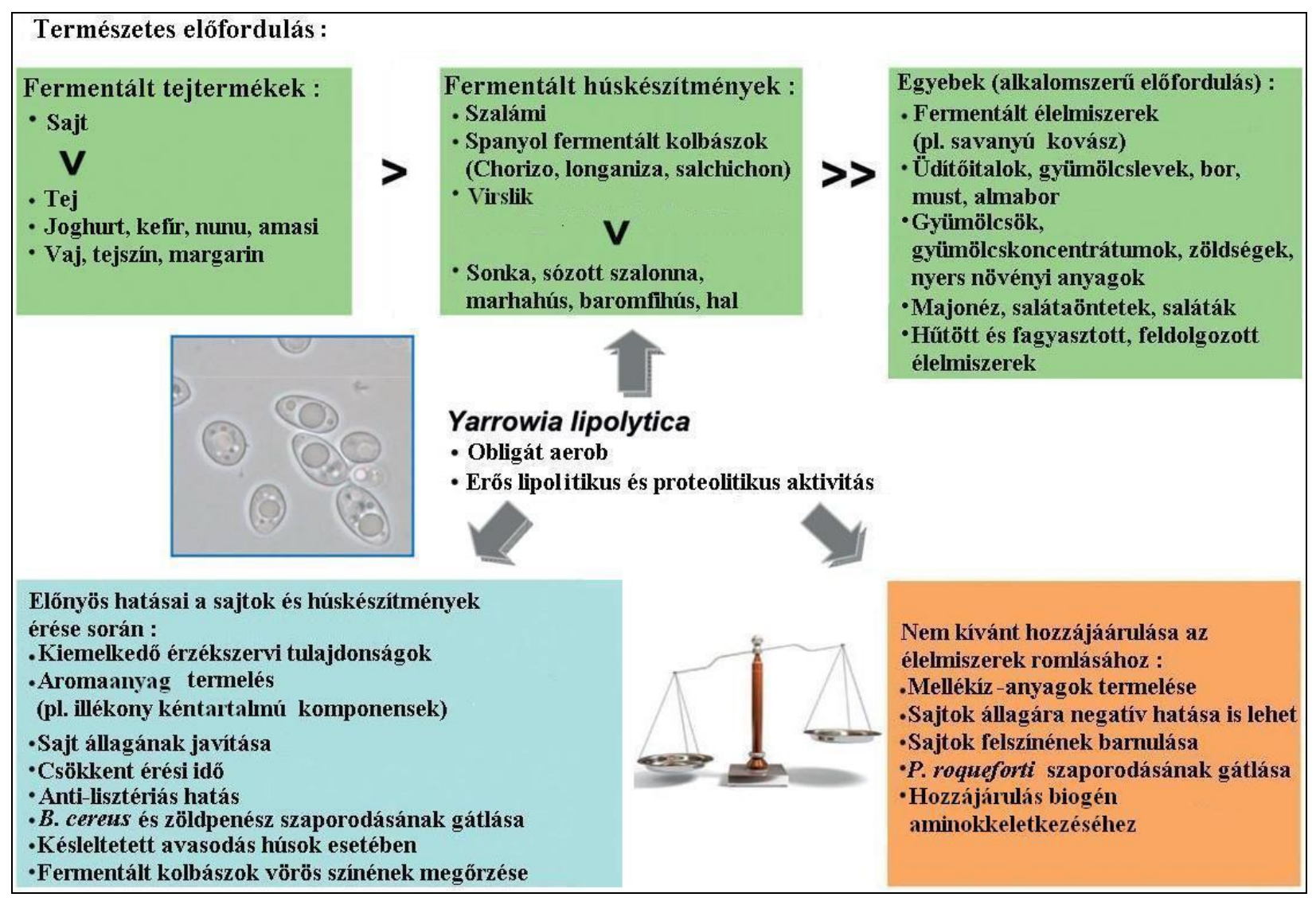

1. ábra. A Y. lipolytica anyagcseréjének hatása természetes előfordulására, az élelmiszerek érésére és romlására. A „,> (vízszintes és függőleges irányban) nagyobb gyakoriságot, legalábbis kimutatásának nagyobb gyakoriságát jelzi. Forrás: Groenewald et al. 2013.

\subsubsection{A Yarrowia csoport tagjainak előfordulása és szerepe tejtermékekben}

Számos publikáció számol be a $Y$. lipolytica előfordulásáról különböző sajtokban. Világszerte végeztek erre vonatkozó vizsgálatokat. Y. lipolytica-t gyakran izolálnak érlelt kérgü lágysajtokból, például a camembertből és kéksajtokból, még akkor is, ha nem alkalmazták 
starterkultúraként (Addis et al. 2001). Számos esetben említik a sajtokból izolált leggyakoribb élesztőgombák között (Roostita és Fleet 1996; Welthagen és Viljoen 1998; Larpin et al. 2006; Monnet et al. 2010). Olyan tulajdonságokkal rendelkezik (magasabb sókoncentráció- és alacsony hőmérséklettürő képesség, laktát és citrát asszimilációjára, valamint extracelluláris lipolitikus és proteolitikus enzimek termelésére való képesség), melyek előnyös helyzetbe juttatják a többi élesztőgombafajjal való versengés során, így nemcsak képes szaporodni tejtermékekben, hanem akár dominánssá is válhat. (Lanciotti et al. 2005).

Welthagen és Viljoen (1998) magyarázata szerint a $Y$. lipolytica sajtokban való előfordulása azzal magyarázható, hogy a sajt vagy az üzem berendezéseiről, a dolgozók testfelszínéről szennyeződik vele, vagy már jelen van a mikroba a gyártáshoz felhasznált tejben. Nem találtak egyértelmü különbséget a $Y$. lipolytica nyers vagy pasztőrözött tejből készült sajtokban való előfordulása között (Groenewald et al. 2013). Egyes szerzők a sajtgyártás során használt sós levet említik a mikroba potenciális forrásaként (Seiler és Busse 1990; Bintsis et al. 2004).

A Y. lipolytica-t kisebb gyakorisággal tudták izolálni nyers tejből, például szarvasmarha, juh és vizibivaly tejéből és egyéb tejtermékekből (Corbo et al. 2001; Chen et al. 2010). Előfordul fermentált tejtermékekben, kefírben, joghurtban (Rohm et al. 1992; Gadaga et al. 2000; LourensHattingh és Viljoen 2002; Fröhlich-Wyder 2003; Viljoen et al. 2003; Bai et al. 2010). Mayoral és munkatársai (2005) szerint a joghurtból izolált élesztőgombatörzsek 15\%-át teszi ki, ezzel joghurtban a harmadik leggyakoribb élesztőgombafaj. Szintén az egyik leggyakoribb élesztőgomba vajban (Lanciotti et al. 1992, Sinigaglia et al. 1994; Lopandic et al. 2006), előfordul tejszínben és margarinban is (Pitt és Hocking 2009).

Lipolitikus és proteolitikus aktivitása miatt a $Y$. lipolytica-t összefüggésbe hozták sajtok érésével, bizonyos esetekben romlásával is. A különbözö tanulmányok eredményei között van némi ellentmondás azzal kapcsolatban, hogy a Y. lipolytica hozzájárul-e a sajtok romlásához és milyen mértékben. A szerzők többsége úgy gondolja, hogy kiemelkedő szerepet játszik ez a mikroorganizmus a sajt romlásában (Westall és Filtenborg 1998; Fröhlich-Wyder 2003; Daryaei et al. 2010; Ramos et al. 2012). Egyes szerzők vizsgálataik során azt tapasztalták, hogy a $Y$. lipolytica sejtszáma a sajtok érlelésének végéhez közeledve emelkedett (Brocklehurst és Lund 1985; Welthagen és Viljoen 1998), más szerzők szerint pedig az összes élesztőgomba, köztük a Y. lipolytica száma is állandó maradt, vagy akár még csökkent is az érési idő előrehaladtával (van den Tempel és Jakobsen 1998; Ferreira és Viljoen 2003). Néhányan arról számoltak be, hogy mellékízt okoz (Bintsis és Robinson 2004), negatívan hat a sajtok állagára (Westall és Filtenborg 1998), fokozza a biogén aminok képződését (Wyder et al. 1999; Gardini et al. 2006; 
Linares et al. 2012) és gátolja a Penicillium roqueforti szaporodását (van den Tempel és Jakobsen 2000). Az ellentmondásokra magyarázatként szolgál, hogy ezekkel a tulajdonságokkal kapcsolatban törzs-specifikus különbségeket figyeltek meg (van den Tempel és Jakobsen 2000).

A Y. lipolytica-t összefüggésbe hozták sajtok felszíni barnulásával is (Carreira et al. 1998; Ross et al. 2000; van den Tempel és Jakobsen 2000). Az általa termelt tirozináz enzim a tirozin oxidálásával okozza a barnulást, mely főleg az érési idő végén jelentkezik, amikor a pH alacsonyabb (Carreira et al. 1998; Ross et al. 2000; Carreira et al. 2001). Akár a sajt egész felszíne megbarnulhat és bár ez a hiba nincs hatással a sajt minőségére, a megjelenése meglehetősen ellenszenves a fogyasztók számára, ami miatt visszautasítják a terméket, ez pedig jelentős gazdasági veszteséget okoz (Carreira et al. 1998). Az elszíneződésért felelős piomelanin pigment a tirozin bomlásából származó homogentizinsav vagy homoprotokatechinsav $Y$. lipolytica sejtek körüli felhalmozódása, majd lúgos környezetben auto-oxidációja és polimerizációja révén keletkezik (Carreira et al. 2001). Néhány előbbieknek ellentmondó megfigyelést is tettek. Van den Tempel és Jakobsen (1998) szerint nem a Y. lipolytica, hanem a Candida famata (Debaryomyces hansenii) felelős a barna pigmentek termelődéséért. Bár a $D$. hansenii valóban képes pigmentek termelésére, azok más úton keletkeznek, mint a $Y$. lipolytica által termelt pigmentek (Carreira et al. 1998). Carreira és munkatársai (2002) Camembert sajttal végzett vizsgálatukkal kapcsolatban arról számolnak be, hogy a pigmentképzés mérsékelhető $Y$. lipolytica és Penicillium candidum együttes alkalmazásával.

Brocklehurst és Lund (1985) vizsgálata szerint a tárolhatósági idő végéhez közeledve túróban megnövekedett a $Y$. lipolytica sejtszáma, mégsem azonosították ezt az élesztőt a láthatóan romlott részből. Néhány szerző (van den Tempel és Jakobsen 2000; Williams és Withers 2007) azt a következtetést vonta le, hogy a romláshoz való hozzájárulás is kifejezett törzs-specifikus különbséget mutat.

A fent említettekkel szemben a $Y$. lipolytica előnyös hatásait sem szabad figyelmen kívül hagyni. Az iparban kevert mikrobapopulációkat alkalmaznak az ízek javítása és a pH csökkentése érdekében, valamint, hogy gátolják a nem kívánt fajok szaporodását és stabilizálják a terméket, vagy elérjék a kívánt érzékszervi tulajdonságokat. Ezek megvalósításában az élesztőgombák is részt vesznek, köztük esetenként a $Y$. lipolytica is pozitív szerepet játszik (Viljoen 2006). Számos szakcikk számol be az élesztőgombák fontos szerepéről a sajt- és más fermentált tejtermékek ízének és állagának kialakításában azok előállítása során, a $Y$. lipolytica-t a leggyakoribbak és legfontosabbak között említik (Fröhlich-Wyder 2003). 
Többen megállapították (Wyder et al. 1999; Fröhlich-Wyder 2003; De Wit et al. 2005; Lanciotti et al. 2005), hogy a $Y$. lipolytica hozzájárul olyan érzékszeri tulajdonságok kialakulásához, mint a sajt aromája, állaga, íze. Az aromatermelés nagyrészt az illékony kéntartalmú komponensek, például a metántiol, dimetilszulfid, dimetilszulfit, vagy metionol által valósul meg, utóbbi mellesleg a borok egyik fó aromakomponense (Martin et al. 2001; Spinnler et al. 2001; López Del Castillo-Lozano et al. 2007; Liu és Crow 2010). Pozitív hatást fejt ki Cheddar, Raclette- és alacsony zsírtartalmú sajtok ízére (Wyder et al. 1999; Ferreira és Viljoen 2003). Sajtelőállítással kapcsolatos kísérletekben az érzékszervi vizsgálatok során a $Y$. lipolyicaval inokulált sajtok kapták a legjobb értékelést (Lanciotti et al. 2005).

A Y. lipolytica alkalmazásának további előnyei közé tartozik az érlelési idő lerövidülése, ami gazdasági előnyökkel jár, ezen kívül valószínüleg hozzájárul a sajtok eltarthatósági idejének meghosszabbodásához is (Ferreira és Viljoen 2003; Fröhlich-Wyder 2003).

Néhány tanulmányban az is felmerült, hogy a Y. lipolytica gátolja a Bacillus cereus, a Listeria és a zöldpenész szaporodását (Addis et al. 2001; Lanciotti et al. 2005; Monnet et al. 2010). Larpin és munkatársai (2006) megállapították, hogy a Y. lipolytica létfontosságú a Livarot sajt ökoszisztémájának egyensúlyához és szintén említették az érzékszervi tulajdonságokra gyakorolt pozitív hatását.

Ezekre az előnyös tulajdonságokra hivatkozva számos kutatócsoport támogatja, hogy sajtok érleléséhez a $Y$. lipolytica-t is alkalmazzák starterkultúraként (van den Tempel és Jakobsen 2000; Addis et al. 2001; Zarowska et al. 2004; Lanciotti et al. 2005). Több szerző is megállapította, hogy a $Y$. lipolytica rendelkezik azokkal a fontos tulajdonságokkal, amik starterként való alkalmazásához szükségesek, mint például a proteolitikus aktivitás, kompatibilitás a tejsavstarter kultúrákkal, és, hogy képes a természetesen előforduló élesztőgombákkal (Debaryomyces hansenii és Saccharomyces cerevisiae) versengeni (Gori et al. 2010). Néhány tanulmányban a $Y$. lipolytica más mikroorganizmusokkal, különösen a $D$. hansenii-vel való szinergista hatásait hangsúlyozták (Freitas et al. 1999; De Wit et al. 2005). Wyder et al (1999) azt tapasztalta, hogy a Y. lipolytica képes csökkenteni a D. hansenii érzékszervi tulajdonságokra kifejtett negatív hatását. Kemény sajtok gyártásakor kiegészítő starterként alkalmazva a $Y$. lipolytica-t és $D$. hansenii-t, azok támogatják a többi starter mikrobát az érlelés során (De Wit et al. 2005). Együttes alkalmazásuk hatékonyságára magyarázatként szolgálhat Addis és munkatársai (2001) megállapítása, mely szerint a $D$. hansenii egyes törzsei fokozzák a $Y$. lipolytica szaporodását.

Wyder és munkatársai (1999) szerint a sajtgyártás során a kiemelkedő aroma elérésének érdekében soha nem szabadna kihagyni a $Y$. lipolytica-t a folyamatból. A fentebb említett 
szerzők ennél óvatosabb kijelentéseket tettek, szerintük bár érdemes a $Y$. lipolytica-t társkultúraként alkalmazni, erős enzimaktivitása, a $P$. roqueforti növekedésének gátlása és az elszíneződéshez való esetleges hozzájárulása miatt a szaporodását nagyon körültekintően szabályozni kell (Cantor et al. 2004). Romano és munkatársai (2006) szerint a sajtgyártásban starterkultúraként való alkalmazása esetleg nehezen kontrollálható lehet kifejezett proteolitikus és lipolitikus aktivitása miatt.

A fentiekböl látható, hogy a sajtelőállítás során mennyire keskeny a határ a Y. lipolytica elönyös hatásai és az alkalmankénti romláshoz való hozzájárulása között. Ráadásul a fogyasztók íz- és illat preferenciái eltérőek lehetnek, így ami egyesek szerint kívánatos, mások romlásnak tekinthetik (Bourdichon et al. 2012).

Több lehetőség is van arra, hogy a kereskedelmi sajtgyártás során kiküszöböljék a $Y$. lipolytica esetleges túlszaporodásából adódó káros hatásokat, a mellékízek és -illatok megjelenését, a $P$. roqueforti szaporodásának gátlását. Megoldást jelenthet például, ha az érlelőkultúrákban egyedüli törzsek helyett kiegyensúlyozott összetételü mikrobaközösségeket alkalmaznak, vagy élő mikroorganizmus helyett $Y$. lipolytica-ból izolált enzimeket, extraktumokat vagy $Y$. lipolytica által termelt aromákat használnak (Groenewald et al. 2013). Mivel némiképp érzékeny a magas $\mathrm{NaCl}$ koncentrációra, szaporodása ezzel korlátozható lehet például kéksajtokban (Romano et al. 2006).

Számos kísérletet végeznek arra vonatkozóan, hogyan lehet bevonni a $Y$. lipolytica-t komplex sajt mikroba-közösségekbe (Martin et al. 2001; Deetae et al. 2009; Delbes-Paus et al. 2012; Irlinger et al. 2012). Lourens-Hattingh és Viljoen (2002) szerint a probiotikus baktériumok szaporodásának támogatása és életben maradása végett a joghurtelőállítás során is érdemes megfontolni a $Y$. lipolytica starterkultúraként való alkalmazását.

\subsubsection{A Yarrowia csoport tagjainak előfordulása és szerepe húsokban és húskészítményekben}

A Y. lipolytica előfordulását a tejhez és tejtermékekhez hasonlóan húsban és halban is gyakran megfigyelték (Deák 2008), főleg darált és szeletelt hús esetében az egyik leggyakrabban izolált élesztőgomba (Fleet 1992). Friss marhahúsból (Liang 1989) és kolbászokból (Viljoen et al. 1993) is gyakran izolálják. Az alacsony hőmérséklethez, magas sókoncentrációhoz és alacsony pH értékhez való alkalmazkodó-képességének köszönhetően fermentált kolbászokban az egyik leggyakoribb élesztőgomba (Romano et al. 2006). 
Egy 1987-es vizsgálat során friss marhahúsból izolált élesztőgombák 69\%-át, valamint sonkából izolált élesztők 62\%-át azonosították Y. lipolytica-ként (Liang 1989). Ezzel szemben egy irodalmi áttekintés (Fung és Liang 1990) szerint különböző húsokból izolált 41 törzs közül egyik sem $Y$. lipolytica.

A Y. lipolytica-t izolálták hütve tárolt vagy besugárzott baromfihúsból is (Sinigaglia et al. 1994; Ismail et al. 2000). Pácolt baromfihúsból izolált élesztőgombák 45,5\%-át, sült baromfihúsból izolált élesztőgombák 54,5\%-át azonosították $Y$. lipolytica-ként, de csirkemájon, -szárnyon és pulykanyakon, pulykakolbászban is a legnagyobb számban mutatták ki (Ismail et al. 2000). Kimutatták spanyol fermentált kolbászokból (Encinas et al. 2000), német kolbászokból, (Samelis és Sofos 2003), bécsi (Viljoen et al. 1993), frankfurti (Drake et al. 1959) és más virslikből, sonkából (Liang 1990), napon szárított hússzeletböl (Wolter et al. 2000); szalámiból (Gardini et al. 2001) és halból (Leme et al. 2011). Abunyewa és munkatársai (2000) vizsgálatai alapján szalámiban a harmadik leggyakoribb élesztőgomba, az izolált élesztők közel 14\%-a tartozott ebbe a fajba. Pastirmából (török préselt hús) a második legnagyobb számban izolált élesztőgomba (12\%) a C. (Y.) deformans volt, $11 \%$-uk C. galli, 10\%-uk C. alimentaria, 5\%-uk $Y$. lipolytica. Ezek az élesztőgombák a termék előállítása során minden mintavételi pontnál megtalálhatók voltak (Ozturk 2015). Nielsen és munkatársai (2008) nyers húsból és szalonnából egyaránt izoláltak $Y$. lipolytica-t és $C$. alimentaria-t.

Akárcsak a sajtok esetében, kolbászok és más húsipari termékek érésével és/vagy romlásával is összefüggésbe hozták a $Y$. lipolytica-t, és szintén megállapították, hogy e két jelenség között keskeny a határ.

A Y. lipolytica húsok romlásához való hozzájárulását néhányan megkérdőjelezik csakúgy, mint sajtok esetében. Groenewald és munkatársai (2013) irodalmi áttekintése alapján egyes vizsgálatok szerint a $Y$. lipolytica sejtszáma szalámiban éles csökkenést mutatott az érési idő végéhez közeledve, Nielsen és munkatársai (2008) szerint az eltarthatósági idő végén nem volt kimutatható a vizsgált húskészítményekben. Viljoen és munkatársai (1993) vizsgálata alapján elsősorban friss húsokban fordul elő, más esetekben inkább romlott húsokból tudták nagyobb számban izolálni (Viljoen et al. 1998).

Néhány szerző szerint kiemelkedő szerepe van a $Y$. lipolytica-nak a húsok romlásában (Ismail et al. 2000; Samelis és Sofos 2003; Deák 2006). Viljoen és munkatársai (1998) szerint annak ellenére, hogy az élesztőgombák csak ritkán közvetlen okai a romlásnak, mégis szilárdan képviseltetik magukat a romlott baromfihúsok mikroba-közösségében. Vizsgálatuk során $Y$. lipolytica-t is detektáltak, a baromfi termékek romlásának előrehaladásával egyre nagyobb 
számban. A Y. lipolytica mellékíz kialakulását és közvetve biogén aminok mennyiségének növekedését is okozza (Wyder et al. 1999; Gardini et al. 2006). Egy esetben az érzékszervi bírálók nem értékelték jónak a $Y$. lipolytica kolbászérlelésben való alkalmazását (Iucci et al. 2007).

Számos élesztőgomba, köztük gyakran a $Y$. lipolytica is jelentősen hozzájárul fermentált húskészítmények ízének kialakulásához, ellensúlyozzák vagy módosítják a kevert baktériumstarterkultúrák tevékenysége által okozott savas pH-t (Viljoen 2006).

A kolbászok fermentációjában és sonkák érlelésében legnagyobb szerepet játszó élesztőgombák között szerepel a $Y$. lipolytica, hozzájárulva az említett termékek ízének és színének kialakulásához (Samelis és Sofos 2003). Selgas és munkatársai (2003) megállapították, hogy a $Y$. lipolytica fokozza az illékony komponensek képződését, ezzel javítva a késztermék ízét és érzékszervi minőségét.

Romano és munkatársai szerint (2006) az élesztőgombák feladata, hogy késleltessék az avasodást, megóvják a nitrozomioglobint az oxidatív bomlástól, ezáltal megőrizzék a fermentált kolbászok tetszetős vörös színét. A Y. lipolytica képes a szabad zsírtartalmat lecsökkenteni (Gardini et al. 2001), a telítetlen szabad zsírsavakat ízkomponensekké metabolizálni vagy oxidálni (Ordoñez et al. 1999). Sőt, az általa termelt lipázok pH 5,5 értéken a telített szabad zsírsavak felszabadulásának kedveznek, ami pozitív hatással lehet az avasodás csökkentésére, ami elsősorban a többszörösen telítetlen szabad zsírsavak miatt következik be (Romano et al. 2006).

Csakúgy, mint sajtok esetében, néhány szerző (Gardini et al. 2001; Romano et al. 2006; Patrignani et al. 2007, 2011) javasolta a $Y$. lipolytica szárazfermentált kolbászok starterkultúrájában való alkalmazását azzal indokolva, hogy szerintük ez az élesztőgomba bizonyítottan hozzájárul a kolbászok kiemelkedő érzékszervi tulajdonságához és általános minőségéhez, sőt valószínüleg az érési idő lerövidüléséhez is. Romano (2006) szerint komoly érdeklődésre adhat okot starterkultúraként való alkalmazása a hagyományos szárazfermentált kolbászok gyártásában, mivel fokozott proteolitikus aktivitása által hozzájárul a fehérjék lebontásához, lipolitikus aktivitása által pedig a lipidek arányát változtatja meg, lerövidítheti az érlelési időt.

A fentiek alapján belátható, hogy a törzsspecifikusságnak milyen nagy szerepe van abban, hogy az adott mikroorganizmus az adott termékek éréséhez vagy romlásához járul-e hozzá és milyen mértékben. 


\subsubsection{A Yarrowia csoport tagjainak előfordulása és szerepe egyéb élelmiszerekben}

A húson, húskészítményeken és tejtermékeken kívül más élelmiszerek széles körében is kimutatták a $Y$. lipolytica-t. Előfordul fermentált élelmiszerekben, például tempeh-ben (indiai eredetü, főtt szójababból készülő, nemes penészes érleléssel előállított élelmiszer), kovászban, savanyú kovászban (Samson et al. 1987; Romano et al. 2006). Izolálták még üdítőitalokból (Stratford 2006), gyümölcskoncentrátumokból (Sancho et al. 2000), majonézből (Buick és Damoglou 1989), valamint hütött és fagyasztott, feldolgozott termékekből (Diriye et al. 1993; Ismail et al. 2000).

A sajttal és hússal összefüggő fent említett példák mellett olyan beszámolók is megjelentek, amik felvetik, hogy a Y. lipolytica hozzájárulhat a vaj, (Lopandic et al. 2006), margarin (Pitt és Hocking 2009), joghurt (Liu és Tsao 2009), majonéz alapú saláták (Buick és Damoglou 1989), halak és tenger gyümölcsei (Fleet 1992; Oh et al. 1998; Deák 2006) romlásához. Akár $500 \mathrm{db} Y$. lipolytica sejt is elegendő ahhoz, hogy nem kívánt mellékízt okozzon margarinban (Pitt és Hocking 2009).

A fent említett tanulmányok során csak néhány esetben alkalmaztak molekuláris módszereket a mikrobák azonosításhoz, így a legtöbb esetben feltételezhető, hogy a Y. lipolyticaként említett törzsek egy része valójában a Yarrowia csoport más fajaihoz tartozik.

\subsubsection{A Yarrowia csoport tagjainak előfordulása élelmiszereken kívül}

A Y. lipolytica széleskörüen elterjedt a természetben. Izolálták törzseit őrölt kukoricából, rost maradványokból, szaruhártya sebből, kőolajtároló tartályból, köpetből, talajból. Elsődleges élőhelye a természetben nem ismert, de gyakran izolálják nagy lipid-tartalmú helyekről, tengeri környezetböl, többek közt nagy sótartalmú vizekből, mint például a Holt-tenger, vagy a NagySóstó. Ezeken kívül izolálták szarvasmarhák és halak ürülékéből, emberek szájüregéből (Kurtzman et al. 2011), kőolajjal szennyezett tengervízből (Palande et al. 2014).

$Y$. deformans-t izoláltak emberröl, körömröl; $C$. hollandica-t szarvasmarha hátáról, $C$. hispaniensis-t cincér lárvából (Kurtzman et al. 2011); Y. divulgata-t mélytengeri vízből és óceáni halakról (Nagy et al. 2013); Y. porcina-t trópusi folyó üledékéből (Nagy et al. 2014), Y. keelungensis-t tenger felszíni rétegéböl (Chang et al. 2013). 


\subsection{A Yarrowia csoport taxonómiája és diverzitása}

A legutóbbi filogenetikai besorolás szerint a Yarrowia nemzetség a Saccharomycetes osztályban, a Saccharomycetales rendben helyezkedik el és a Wickerhamiella testvércsoportja (Kurtzman 2011).

A Yarrowia nemzetségben sokáig a Yarrowia lipolytica volt az egyetlen ismert teleomorf (ivaros) faj, anamorf (aszexuális) változata a Candida nemzetségbe tartozik, neve Candida lipolytica, 1921-ben Hollandiában izolálták lejárt fogyaszthatósági idejü margarinból. Jacobsen, aki tanulmányozta, lipolitikus tevékenysége miatt Torula lipolytica-nak nevezte (nom. nud.), de nem írta le a fajt. A törzs Harrisonhoz került, aki a Mycotorula nemzetségbe sorolta és 1928-ban Mycotorula lipolytica néven írta le. Álhifa képzésére való képessége miatt 1942-ben a Candida nemzetségbe sorolták és néhány korábban leírt fajt is $C$. lipolytica-val megegyezőnek találtak (Lodder és Kreger-van Rij 1952). Ezek a fajok a következők: Monilia cornealis, Proteomyces cornealis, Pseudomonilia deformans, Candida deformans (Lodder és Kreger-van Rij 1952).

Lodder és Kreger-van Rij (1952) szerint Kreger-van Rij és Verona 1949-ben írta le az olajbogyóról izolált Candida olea-t, amit a C. lipolytica-tól különálló fajnak hittek, mivel azt tapasztalták, hogy sejtjei általában rövidebbek, az álhifái eltérő módon fejlődnek, nem képez valódi hifát és a $C$. lipolytica-val ellentétben maláta levesben csak vékony hártyát képez és egyedüli szénforrásként etanolt tartalmazó tápközegben jobban szaporodik. Lodder-t és Kregervan Rij-t (1952) négy újabb lipolitikus törzs izolálása késztette arra, hogy felülvizsgálják az említett két faj közti különbségeket, amelyek többségét vizsgálataik során nem tapasztalták, így arra a megállapításra jutottak, hogy a $C$. olea-t szintén megegyezik a $C$. lipolytica-val.

A C. lipolytica teleomorf alakját Wickerham és munkatársai írták le 1970-ben Endomycopsis lipolytica-ként. Egy évvel később van der Walt és Scott (1971), majd von Arx (1972) rámutattak, hogy az Endomycopsis nemzetségnév érvénytelen, mert csupán szinonimája a Saccharomycopsis-nak. Így a legtöbb Endomycopsis fajt van der Walt és Scott (1971) átsorolták más nemzetségekbe, azonban az Endomycopsis lipolytica-t ekkor még nem. Ezt a fajt Yarrow (1972) vizsgálta tovább és sorolta át a Saccharomycopsis nemzetségbe, így új neve a Saccharomycopsis lipolytica lett. Yamada és munkatársai (1976) megfigyelték a S. lipolytica-nál a Q-9 koenzim jelenlétét, míg az Endomycetaceae és Saccharomycetaceae családok legtöbb tagja Q-6, Q-7 vagy Q-8 koenzim Q-rendszerekkel rendelkezik, ezzel előrevetítették új nemzetségbe sorolását. Néhány évvel később van der Walt és von Arx (1980) felismerték, hogy a S. lipolytica szénhidrát-összetételében is különbözik az említett családok fajaitól, mivel sejtjei galaktózt 
tartalmaznak. Ezen kívül felfigyeltek arra is, hogy a S. lipolytica aszkospórái mind méretüket, mind alakjukat tekintve nagy változatosságot mutatnak, ezzel egyedinek tünnek a többi Saccharomycopsis faj aszkospóráihoz hasonlítva. Az említett eltérésekre hivatkozva bevezettek egy új nemzetséget, a Yarrowia-t, melynek típusfajaként az ide átsorolt S. lipolytica-t jelölték ki, Yarrowia lipolytica névvel. Mivel akkor még nem voltak ismertek közvetlen rokonai, a $Y$. lipolytica egy jól elkülönülő helyet foglalt el az Endomycetales rendben (van der Walt és von Arx 1980).

A Yarrowia (C.) deformans-t, ahogy fentebb említettem, 1942-töl a C. lipolytica-val azonos fajnak tekintették. Van Uden és Buckley (1970) fenotípusos jellemzői alapján még mindig a $C$. lipolytica változatának tekintették, mint $C$. lipolytica var. deformans, amit $\beta$ glükozid-asszimiláló képessége alapján különítettek el a C. lipolytica var. lipolytica-tól. Meyer és munkatársai (1984) morfológiai és fiziológiai tulajdonságok alapján úgy gondolták, hogy a $C$. deformans az akkoriban S. lipolytica-nak nevezett $Y$. lipolytica imperfekt, aszexuális változata. Mivel aszkospórákat találtak a $C$. deformans típustörzsének és frissen izolált $Y$. lipolytica törzsek keverékében, így arra a következtetésre jutottak, hogy a $C$. deformans a $Y$. lipolytica szinonimájaként tekinthető. Így a Yarrowia nemzetség későbbi feldolgozásakor Kurtzman (1998) a C. deformans-t még mindig a Y. lipolytica szinonimájaként említette.

Az 1990-es évektől kezdve elkezdték az élesztőgombákat filogenetikai megközelítés alapján újrarendszerezni (Bigey et al. 2003; Knutsen et al. 2007; Kurtzman és Robnett 1994, 1995, 1998; Suzuki et al. 1999). Ezek a tanulmányok betekintést engedtek a Y. lipolytica és a Yarrowia csoport többi fajának filogenetikai elhelyezkedésébe és lehetővé tették a fajok közti határok megismerését. A SSU rRNS (Suzuki et al. 1999) és a részleges LSU rRNS génszekvenciák (Kurtzman és Robnett 1994, 1995, 1998) összehasonlítása eredményeként arra a megállapításra jutottak, hogy a $Y$. lipolytica távoli rokona a legtöbb ismert aszkuszos élesztőgombának. Kurtzman és Robnett 1995-ben és 1998-ban a Y. lipolytica legközelebbi rokonának az Aciculoconidium aculeatum-ot vélte, de a legfrissebb, 5 gén vizsgálatán alapuló vizsgálat (Kurtzman és Robnett 2013) eredménye egy korábbi, 1994-ben megjelent publikációjukkal van összhangban, mely szerint a Wickerhamiella a Yarrowia nemzetség legközelebbi rokona. Az említett vizsgálatok alapján $Y$. lipolytica-t taxonómiailag akkoriban a Hemiascomycetes osztályba sorolták, azonban néhány tulajdonságban eltér az ebbe a csoportba tartozó fajoktól, mint például az rRNS gének egyedi sejtmagi rendeződése (Fournier et al. 1986). Bigey és munkatársai (2003) különbségeket találtak a $Y$. lipolytica és a $C$. deformans lipáz génjeit kódoló régióinak szekvenciái között, ezáltal elsőként ismerték fel, hogy két különálló 
fajról van szó. Megállapításukat alátámasztották azzal, hogy 14 nukleotid különbséget találtak a 26S rRNS gének D1/D2 régiói között.

2004-ben Péter és munkatársai csirkemellből és csirkemájból származó törzsek alapján leírták a Candida galli-t. Ezek a törzsek fenotípusos tulajdonságaik alapján a Yarrowia lipolytica-ra hasonlítottak, de rRNS génjük kis (18S) és nagy (26S) alegysége alapján egyértelműen új fajnak bizonyultak. A C. galli a genetikai különbségen felül rendelkezik olyan fiziológiai tulajdonsággal is, mely alapján elkülöníthető a Yarrowia lipolytica-tól (Péter et al. 2004).

Knutsen és munkatársai (2007) fontosnak találták, hogy újra megvizsgálják a $Y$. lipolytica-val szinonim fajok típustörzseit és újraértékeljék a nemzetség rendszertanát. Alapos vizsgálatokat folytattak a Yarrowia és közeli rokon Candida fajokon különböző technikákat alkalmazva, mint például PCR-ujjlenyomat elemzése, a D1/D2 és ITS régiók szekvenciaanalízise és párosítási kísérletek, továbbá tanulmányozták a fajok fiziológiáját és morfológiáját. Két korábban leírt fajt, a C. galli-t és (az akkor még Candida yakushimensis-nek nevezett - de latin leírás hiányában nomen invalidum) Yarrowia yakushimensis-t is bevonták a vizsgálataikba, és leírtak három új, Yarrowia csoportba tartozó fajt: a Candida alimentaria-t, Candida hollandica-t és a Candida oslonensis-t. Bebizonyították, hogy a fent említett fajok elkülöníthetők egymástól a LSU rRNS génjeik D1/D2 régióinak, valamint ITS régióinak szekvenciái között található eltérések alapján. Megerősítették Bigey és munkatársai fentebb említett következtetését, hogy a $Y$. lipolytica és a $C$. deformans két külön faj, mivel jelentős különbséget találtak e két faj fent említett szekvenciái között. A legutóbbi rendszertani feldolgozásban a $C$. deformans és a $Y$. lipolytica már külön fajokként szerepelnek (Kurtzman et al. 2011).

Knutsen és munkatársai (2007) fajok közti párosodásra utaló aszkospórákat találtak a $Y$. lipolytica, C. deformans és $C$. galli néhány törzsének keverékében, de a Candida fajokon belül nem találtak komplementer párosodási típusokat. C. deformans törzsek között Groenewald és Smith (2013) figyeltek meg párosodást és aszkospóraképzést, és leírták a C. deformans teleomorf alakját, a Yarrowia deformans-t, a Yarrowia nemzetség második teleomorf faját, valamint a Yarrowia yakushimensis-t.

A $C$. alimentaria, $C$. hollandica és a $C$. oslonensis leírása után egy évvel Limtong és munkatársai (2008) írták le a Candida phangngensis-t, az e faj törzseinek és a $Y$. lipolytica, $C$. deformans és C. galli törzseinek D1/D2 és SSU szekvenciái között talált eltérések alapján.

Kurtzman és munkatársai a fent említetteken kívül a Yarrowia csoport tagjaként említik a C. hispaniensis-t (Kurtzman 2005; Kurtzman et al. 2011). 
Chang és munkatársai (2013) írták le a Yarrowia keelungensis-t, egy tenger felszíni rétegéből izolált törzs alapján, ami nagymértékben képes kőolaj-szénhidrogén bontására.

2013-ban és 2014-ben még három új, Yarrowia nemzetségbe tartozó faj, a $Y$. divulgata, a $Y$. porcina és a Y. bubula leírására került sor (Nagy et al. 2013, 2014).

A C. bentonensis-t néhányan szintén a Yarrowia csoportba sorolták (Kurtzman 2005; Kurtzman et al. 2011) annak ellenére, hogy fiziológiai jellemzői jelentősen különböznek a csoport többi tagjáétól. A Y. lipolytica és rokon fajok ITS és D1/D2 szekvenciáinak filogenetikai analízise azonban nem támasztja alá a C. bentonensis Yarrowia csoportba való tartozását, e faj nincs szoros kapcsolatban a vizsgálatba vont Yarrowia csoportba tartozó fajokkal (Nagy et al. 2013).

A gombák nevezéktanáról szóló amszterdami nyilatkozat a molekuláris adatok hozzáférhetőségére hivatkozva javasolja a pleomorf gombák elnevezési rendszerének megváltoztatását (Hawksworth et al. 2011), amit a növények és gombák nevezéktanának nemzetközi konszenzuson alapuló szabálykönyve, az Algák, Gombák és Növények Nevezéktanának Nemzetközi Kódja (McNeill et al. 2012) elfogadott, így 2013-tól elsősorban filogenetikai csoportosításuk szerint történik a gombák rendszerezése. Ez nagy hatással van a gombák nevezéktanára, azon belül a Yarrowia csoportra is, ahol a Candida fajokat elöbb-utóbb a Yarrowia nemzetségbe sorolják, csakúgy, mint az újonnan leírásra kerülő, teleomorf alakkal nem rendelkező fajokat.

\subsection{A Yarrowia lipolytica ipari alkalmazása}

A Y. lipolytica-nak nem csak az élelmiszeriparban van nagy szerepe. Az alábbi fejezetben szeretném röviden bemutatni, milyen sokoldalú és milyen nagy ipari jelentőséggel bír ez az élesztőgomba.

A Y. lipolytica ipari alkalmazásának úttörője a British Petroleum (BP) volt. 1957-ben kezdett el a kiváló minőségű fehérje, úgynevezett „single cell protein” (SCP), egysejtfehérjeelőállítás területén tevékenykedni annak érdekében, hogy a gyorsan növekvő népesség számára elegendő tápanyagkészletet biztosítson. Az ezt követő években kezdték el a $C$. (= Yarrowia) lipolytica-t és a Candida tropicalis-t e területen alkalmazni. Szardínián építettek egy évi 100.000 tonna termelésére alkalmas üzemet, azonban a termék bizonyított biztonságossága ellenére az olasz hatóságok megtagadták az engedélyeket. E kudarc és a nyersanyagok árának nagymértékü emelkedése miatt a BP úgy döntött, hogy SCP termékeit humán élelmezésre való alkalmazása 
helyett haszonállatok takarmányozására fejleszti tovább, ehhez kapcsolódóan kiemelkedő számú és mértékű biztonsági vizsgálatot végzett (Groenewald et al. 2013).

2009-től a lengyel Skotan SA vállalat termel Európában Y. lipolytica biomasszát takarmányélesztőként való használat céljából (1200 tonna/év) (Rywinska et al. 2013).

Mirbagheri és munkatársai (2012) tanulmányából kiderül, hogy a Y. lipolytica még az általánosan alkalmazott Aspergillus niger-nél is hatékonyabban alkalmazható citromsavtermelésre. Ezen kívül egyéb szerves savak termelésére is kiválóan alkalmas, például izocitromsav, $\alpha$-ketoglutársav, piroszőlősav, borostyánkősav és ecetsav termelésére is (Heretsch et al. 2008; Chatzifragkou et al. 2011; Holz et al. 2011; Kamzolova et al. 2009; Otto et al. 2011; Yuzbashev et al. 2011; Kamzolova et al. 2012; Otto et al. 2012; Zhou et al. 2012; Yu et al. 2012).

A $Y$. lipolytica-t mannit-, eritrit- és arabinit termelésére is alkalmazzák (De Zeeuw és Tynan 1973a, b; Chatzifragkou et al. 2011; Tomaszewska et al. 2012). A Y. lipolytica-val termeltetett eritritet felhasználják élelmiszeradalékként, édesítőszerként, ízfokozóként, nedvesítőszerként, stabilizátorként, sürítőanyagként, kelátképzőként és állományjavítóként (Groenewald et al. 2013).

Mivel a $Y$. lipolytica nagy mennyiségü lipidet képes felhalmozni sejten belül az úgynevezett lipidtestekben, megpróbáltak benne lipofil komponenseket túltermeltetni. A linolénsav a legfőbb $Y$. lipolytica-val termeltetett többszörösen telítetlen zsírsav, de a génsebészet segítségével fejleszthetők olyan rekombináns törzsek, melyek túltermelik például az eikozapentaénsavat (EPA), dokozahexaénsavat, arachidonsavat, konjugált linolénsavat vagy $\gamma$-linolénsavat (Damude et al. 2009a, b; Chuang et al. 2010; Zhang et al. 2012).

A $Y$. lipolytica-t alkalmazzák karotinoidok termeltetésére is, amit élelmiszerek és takarmányok természetes színezőanyagaként és stabilizátorként használnak fel (Bailey et al. 2008; Sharpe et al. 2008).

Szintén használható aromavegyületek, például 3-hydroxy- $\gamma$-dekalakton, 2-feniletil acetát és $\gamma$ dekalakton előállítására, utóbbinak jellegzetes barackíze van (Vandamme és Soetaert 2002; Garcia et al. 2009; Bialecka-Florjanczyk et al. 2012).

A Y. lipolytica alkalmas terápiás és ipari fehérjék és enzimek termelésére is. LIP2 lipáza az exokrin hasnyálmirigy-elégtelenség terápiás anyagaként szolgálhat (Turki et al. 2010). Használják lizoszómális tárolási betegségek kezelésében használható enzimek termelésére (Geysens és Vervecken 2011) és gyógyszerek költséghatékony gyártásában használatos epoxidhidrolázok termelésére is (Botes és Mitra 2006; Botes et al. 2007). 
Felvetődött a $Y$. lipolytica bioremediációban és detoxifikációban való számos felhasználhatósága, mint például szénhidrogén-szennyezett talajok és vizek bioremediációja; 2,4,6-trinitrotoluene (TNT), metil-paration, aflatoxinok vagy brómozott szerves anyagok detoxifikációja, szennyvíz kezelése, fém-detoxifikációja (Bankar et al. 2009; Mann és Rehm 1977; Song et al. 2011; Vatsal et al. 2011; Shinde et al. 2012; Wang et al. 2012). Képes trigliceridek és alifás szénhidrogének lebontására (Jain et al. 2004), ásványolaj-termékekkel és nehézfémekkel szennyezett talajok remediációjára is felhasználható (Strouhal et al. 2003). Alacsony hőmérsékleten hatékonyan metabolizálja a gázolajat (Margesin és Schinner 1997). A $Y$. lipolytica élelmiszerek feldolgozásában és kozmetikai készítményekben is alkalmazott felületaktív anyagok termelésére is alkalmas (Amaral et al. 2006; Trindade et al. 2008). Számos emulgeálószert is termel (Cirigliano és Carman 1985; Amaral et al. 2006; Fontes et al. 2010; Rufino et al. 2011). Lipidjei alkalmasak a kakóvaj-helyettesítésére (Papanikolaou és Aggelis 2011).

A Y. lipolytica az említetteken kívül a bioüzemanyag-előállításban is használható lehet, az általa termelt lipáz felhasználásával biodízel készíthető (Karatay és Donmez 2010; Katre et al. 2012; Tsigie et al. 2012).

Mindezek a példák tanúsítják a $Y$. lipolytica alkalmazhatóságának széles körét, de fontos megjegyezni, hogy a $Y$. lipolytica-ként említett törzsek egy része valószínüleg a Yarrowia csoport más fajaihoz tartozik. A fent említett tanulmányokban felhasznált, Y. lipolytica-ként vizsgált törzsek többsége törzsgyüjteményekből származik, ez azonban nem zárja ki annak a lehetőségét, hogy esetleg előfordul köztük néhány tévesen azonosított törzs is. Sajnos még a legjelentősebb törzsgyüjteményeknél is előfordul, hogy tévesen tartanak vagy tartottak számon egyes törzseket korábbi, hagyományos azonosítás alapján, amire azok molekuláris felülvizsgálata során derült fény. Példaként szolgál erre az American Type Culture Collection (ATCC) munkatársainak, Suh és Zhou 2010-ben megjelent tanulmánya, melyben tizenhárom, mikológiai gyüjteményükben Ogataea polymorpha- és Ogataea thermophila-ként nyilvántartott törzs rRNS génjeit tanulmányozva felismerték, hogy közülük három törzs más rendszertani csoportba tartozik, még csak rokonságban sem állnak az Ogataea nemzetséggel.

A Yarrowia csoport molekuláris módszerrel azonosított többi tagjának ipari alkalmazhatóságáról eddig igen kevés publikáció született.

A C. galli aromatermelő képességéről számoltak be, képes az izoeugenolt vanilliná és vanillinsavvá alakítani (Ashengroph et al. 2011). 
A C. hispaniensis jól szaporodik különféle szubsztrátokon és nagy lipidtároló kapacitást mutat, így ígéretesnek tünik biotechnológiai felhasználás szempontjából, akár önmagában is, vagy génjeinek a Y. lipolytica fejlesztéséhez való felhasználásával (Michely et al. 2013).

A Y. lipolytica élelmiszeriparban való alkalmazásának legalapvetőbb feltétele, hogy egészségre ártalmatlan legyen.

A Y. lipolytica az 1. biológiai biztonsági szintbe tartozik (De Hoog et al. 2010). Ez a csoport olyan mikroorganizmusokat foglal magába, melyekről nem ismert, hogy betegséget okoznának egészséges felnőtt emberekben (Lelieveld et al. 1996). Svájc az egyetlen ország, ahol a $Y$. lipolytica-t a 2 . biológiai biztonsági szintbe sorolták, azzal az indoklással, hogy összefüggésbe hozható néhány opportunista fertőzéssel (Groenewald et al. 2013). Elsősorban súlyosan beteg vagy immunszupresszált betegeket képes megfertőzni, legtöbb esetben centrális véna katéteren keresztül jut a vérkeringésbe (Liu et al. 2013). Fontos különbséget tenni patogenitás és opportunista fertőzés között. Sok mikroorganizmus képes fertőzést okozni, ha hozzáfér a gazda által normál esetben védett szövetekhez. A valódi patogének azonban képesek fertőzést okozni általánosan egészségesnek tekintett egyénekben is (Pariza és Johnson 2001). Így, bár izolálták a Yarrowia lipolytica-t patológiai mintákból (Liu et al. 2013; Groenewald et al. 2013 és a benne található hivatkozások), nem tekintjük patogénnek, mivel csak immunszupresszált egyéneket képes megbetegíteni. 2013-ban Groenewald és munkatársai a rendelkezésre álló szakirodalmat alaposan áttekintették és következtetésként megállapították, hogy a Yarrowia lipolytica takarmányokban és élelmiszerekben való felhasználása, valamint biotechnológiai alkalmazása biztonságos. Haszon- és laboratóriumi állatokon végzett vizsgálatok alapján megállapították, hogy a Yarrowia-eredetű termékek mellékhatások nélkül használhatók.

A Y. lipolytica élelmiszerekben való természetes előfordulása biztonsági szempontból újabb kérdéseket vethetne fel, de fontos hangsúlyozni, hogy az előző fejezetekben ismertetett esetekben az élelmiszerromlás kizárólag az élelmiszer ízére vagy megjelenésére korlátozódott. Egyetlen esetben sem találtak bizonyítékot $Y$. lipolytica-val összefüggő élelmiszermérgezésre vagy egyéb egészségügyi veszélyre. Nem ismertek olyan anyagcseretermékei sem, melyek állatokra vagy emberekre toxikusak lennének (Groenewald et al. 2013), leszámítva a sajtokban és húsokban biogén aminok termelődéséhez való hozzájárulásukat (Gardini et al. 2006), de azok koncentrációja (120 mg/kg-ig) nem hordoz egészségügyi kockázatot (Wyder et al. 1999). Groenewald és munkatársai (2013) szerint az immunszupresszált és katéterezett betegekkel kapcsolatos opportunista fertőzésekhez való esetenkénti hozzájárulása nem súlyosabb, mint más, biztonságosan használt mikroorganizmusoké, mint amilyen például a Saccharomyces cerevisiae. 


\subsection{Az élesztőgombák rendszertani azonosításának módszerei}

Az élesztőgombákat hagyományosan fenotípusos tulajdonságaik alapján azonosítják, mint például számos szén- és nitrogénforrás asszimilációjára való képesség, szaporodás különböző hőmérsékleteken és különböző körülmények között. A The Yeasts - a Taxonomic Study (Kurtzman et al. 2011) ötödik, legfrissebb kiadásában még mindig szerepel az ilyen hagyományos azonosítási módszereken alapuló határozókulcs, és, hogy a $Y$. lipolytica azonosítható ilyen tulajdonságok alapján. Ez azonban nem teljes mértékben igaz, mivel a $Y$. deformans-tól nem minden esetben különíthető el megbízhatóan, sőt, az utóbbi két évben leírt Yarrowia porcina-tól, Yarrowia divulgata-tól és Yarrowia keelungensis-től sem. A Yarrowia csoport fajainak azonosításához megbízható eszköz az ITS és D1/D2 régiók szekvencia analízise (Knutsen et al. 2007). Nemrégiben az ITS régiót univerzális gomba „vonalkód”-ként jelölték ki (Schoch et al. 2012), de élesztőgombák azonosításához a D1/D2 régiók szekvencia analízise elengedhetetlen (Kurtzman et al. 2011).

A fentiek alapján megállapítható, hogy a korábban, hagyományos módszerekkel $Y$. lipolytica-ként azonosított törzsek egy jelentős része nagy valószínüséggel tévesen lett azonosítva. Nielsen és munkatársai (2008) felhívták a figyelmet arra, hogy mivel a Y. lipolytica és $C$. alimentaria egymás mellett előfordulnak húskészítményekben, feltehető, hogy néhány korábban azonosított $Y$. lipolytica valójában talán $C$. alimentaria, vagy a csoport más tagja. Így a $Y$. lipolytica előfordulásáról, élelmiszerekben való szerepéről, ipari jelentőségéről készült beszámolók nem teljesen pontosak, mivel a vizsgált törzsek egy része esetlegesen a csoport más fajait képviselik.

\subsubsection{Morfológiai és fiziológiai tulajdonságokon alapuló hagyományos azonosítás}

Az élesztőgombák hagyományos azonosítása fenotípusos (morfológiai, fiziológiai és biokémiai) tulajdonságokon alapul és számos vizsgálatot foglal magába, ami munka- és időigényes.

Az élesztőgombák számos tulajdonságát vizsgálják az azonosításukhoz, új fajok leírásához. A morfológiai vagy fiziológiai jellemzők megléte vagy hiánya eredetileg az ismeretlen izolátumok azonosítására szolgált. Az élesztők jellemzéséhez és azonosításához használt sztenderd teszteket részletesen ismertetik a monográfiákban (Lodder és Kreger-van Rij 1952; van der Walt 1970; van der Walt és Yarrow 1984; Yarrow 1998; Kurtzman et al. 2011). 
A hagyományos azonosításban fontos szerepe van az ivartalan és ivaros szaporodásnak, a sejtfalszerkezetnek, szeptumok és spórák tulajdonságainak; azoknak a teszteknek, melyek a cukrok erjesztésének és a szén- és nitrogénforrások asszimilációjának vizsgálatára alkalmasak, továbbá, hogy milyen körülmények teszik lehetővé a vizsgált élesztőgomba szaporodását. Az ivaros szaporodás következményeként keletkező spórák száma, alakja, az aszkuszok ellenállósága és a konjugáció létrejötte megkönnyítheti az azonosítást, azonban azok detektálása gyakran különböző tenyészetekből származó komplementer párosodási típusok keresztezését és hosszas inkubációját igényli különböző spóráztató táptalajokon, így a spórák megtalálása rendkívül időigényes és gyakran bizonytalan. Az ivartalan szaporodás jellegzetességei szintén fontosak az azonosításban. A sarjadzás módja (multilaterális, bipoláris, monopoláris), sejtek hasadása, artrokonídiumok és ballisztokonídiumok képzése, a sejtek alakja és mérete, valódi- és álhifa képzése, a telepek jellemzői mind fontos szerepet játszanak a hagyományos azonosításban. Fontos jellemző a különböző szénforrások erjesztésére és szén- és nitrogénforrások asszimilációjára való képesség, szaporodóképesség különböző hőmérsékleteken, vitaminmentes tápközegben, 50\%-os glükóz- vagy 10\%-os NaCl-tartalmú tápközegben; cikloheximid vagy 1\% ecetsav jelenlétében. Az ureáz teszt segítségével a Saccharomycotinák elkülöníthetők a bazidiomikótáktól, az aszkomikóta és bazidiomikóta élesztők megkülönböztetésére a DBB (Diazonium Blue B) teszt szolgál (Deák 2008).

Az ajánlott tesztek száma változó. Ahogy nő a fajok és nemzetségek száma, a megkülönböztetésükhöz szükséges fiziológiai tesztek és figyelembe veendő biokémiai jellemzők száma is növekszik. A legelső taxonómiai monográfiában (Lodder és Kreger-van Rij 1952) még csak hat szénforrás használatát említik a fermentációs és asszimilációs tesztekhez, később ezeknek a száma jelentősen megnőtt, 1984-ben van der Walt és Yarrow már 20 szénforrás felhasználásának tesztelését említi, a legutóbbi monográfia pedig már (Kurtzman et al. 2011) közel száz fenotípusos tesztet említ.

A morfológiai és fiziológiai teszteken alapuló hagyományos azonosításnak több hátránya is van: a tesztek eredményei néha bizonytalanok és az elvégzésük rendkívül idő- és munkaigényes, ugyanazon faj egyes törzsei között a morfológiai tulajdonságok (például a spórák alakja, filamentumok jelenléte) gyakran eltérhet, a fiziológiai tulajdonságokat pedig (például egy szubsztrát felhasználását lehetővé tevő enzim termelődése) gyakran egyetlen gén határozza meg, ami mutáció során megváltozhat. Így az ezeken a teszteken alapuló osztályozásnak komoly korlátai vannak (Deák 2008).

Számos módon próbálták megkönnyíteni az azonosítás folyamatát, például miniatürizált, egyszerüsített módszerekkel, kereskedelemben kapható készletekkel és automatizált 
rendszerekkel. A meghatározás egyszerüsítése és gyorsabbá tétele végett Deák és Beuchat (1987) egy egyszerüsített módszert dolgozott ki az élelmiszerekben gyakran előforduló, romlást okozó élesztőgombák azonosítására. Ezek a biokémiai és fiziológiai tulajdonságon alapuló egyszerüsített tesztek azonban nem nyújtanak elegendő és/vagy megbízható információt az azonosításhoz (Rohm és Lechner 1990, Deák és Beuchat 1993). Napjainkban számos gyárilag elkészített identifikációs gyorsteszt is rendelkezésünkre áll, melyekkel az azonosításhoz szükséges tesztek ideje lényegesen lerövidül, a tesztek száma és az elvégzésükhöz szükséges munka jelentősen csökkenthető. Ebből adódóan e módszerek alkalmazásával a fent említett okok miatt egyébként sem túl megbízható azonosítás így még kevésbé megbízhatóvá válik.

\subsubsection{Molekuláris módszereken alapuló azonosítás}

A megbízható azonosításnak genotípusos tulajdonságokon kell alapulnia, genetikai hasonlóságokat és különbségeket figyelembe véve. Ezt a molekuláris technikák teszik lehetővé, melyekkel azonosíthatók a fajok, de akár fajon belül is elkülöníthetők az egyes törzsek. Alkalmazásuk nagy hatással van az élesztőgombák rendszerezésére, a molekuláris megközelítés lehetővé teszi a rendszertani kategóriák filogenetikai elrendezését (Deák 2008).

A fenotípusos tulajdonságokkal ellentétben a nukleinsav szekvenciákban megnyilvánuló genotípus sokkal stabilabb, mivel a mikroba szaporodása során azt nem befolyásolja annak környezete. Bár a DNS molekulák ki vannak téve mutációknak és szekvenciaátrendeződéseknek, amik a közel rokon fajok, vagy akár még az egy fajhoz tartozó törzsek között is okozhatnak különbségeket (polimorfizmus), a mikroorganizmusok mégis megbízhatóan jellemezhetők DNS vagy RNS szekvenciáik közti különbségek alapján (Deák 2008).

\subsubsection{Polimeráz láncreakció}

A polimeráz láncreakció (PCR) lehetővé teszi specifikus, akár kis mennyiségben jelenlévő DNS szekvenciák exponenciális felszaporítását. Három lépésből álló ciklusok ismétlődésével megy végbe. Az első lépés a denaturálás, amikor magas hőmérsékleten $\left(\sim 95{ }^{\circ} \mathrm{C}\right)$ a DNS két szála elválik egymástól. A második lépés az oligonukleotid primertől függően 40-60 ${ }^{\circ} \mathrm{C}$-on megy végbe, a primer hibridizál az egyszálú DNS szakasszal. Harmadik lépés a lánchosszabbítás, mely polimeráz enzim segítségével megy végbe, ami a reakcióelegyben található dezoxi-ribonukleotid-trifoszfát (dNTP) molekulákat felhasználva végzi a lánchosszabbítást $\sim 2{ }^{\circ} \mathrm{C}$-on. Az e három lépésből álló ciklus 25-35-ször ismétlődik. Egy ciklus 
során a DNS mennyisége megduplázódik. Az utolsó ciklust egy végső lánchosszabbító lépés, majd hütés követi (Deák 1998).

A reakció specifikussága a denaturált, egyszálú DNS-hez hibridizálódó oligonukleotid primer szekvenciájától függ (Saiki et al. 1988). A felszaporított fragmentek detektálásának legegyszerübb módja az agaróz gél-elektroforézissel elkülönített PCR termékek etídiumbromiddal való megfestése, majd UV fénnyel való megvilágítása. Az alap PCR technikának számos változatát dolgozták ki, ezek többsége alkalmazható élesztőgombák azonosítására (Deák 2006).

A rendszertanban és az azonosításban nagy jelentőségü rRNS gének vizsgálatára egyszerüségük és gyorsaságuk miatt jól használhatók a PCR-re alapozott eljárások. Az rRNS gének számos élesztőgombában együtt, sokszor ismétlődő szakaszokban helyezkednek el. Erősen konzervált régiói vizsgálatából többnyire filogenetikai következtetések vonhatók le, a nagyobb variabilitást mutató szakaszok pedig a közeli fajok vagy törzsek elválasztását teszi lehetővé (Deák 1998).

Az rRNS gének vizsgálatán alapuló élesztőgomba-azonosításra a 2.4.2.3. fejezetben ismertetett PCR alapú módszerek alkalmazhatók.

\subsubsection{Tipizálásra alkalmas $P C R$ alapú technikák}

\section{PCR-RAPD}

Találomra alkalmazott rövid primerekkel jellegzetes mintázatot adó reakciótermékeket nyerhetünk. Széles körben elterjedt, mivel alkalmazásához nem szükséges restrikciós hasítás, DNS próba. Számos vizsgálatban előnyösnek bizonyult ez a módszer más molekuláris módszerekkel szemben, azonban hátránya, hogy elsősorban a fajon belüli megkülönböztetést teszi lehetővé és mivel a reakció alacsony hőmérsékleten megy végbe így több véletlenszerü kapcsolódás lehetséges, emiatt az amplifikáció eredménye nehezen reprodukálható (Deák 1998).

\section{AFLP}

Az AFLP technikát szintén használják genetikai diverzitás vizsgálatára. Az eljárás során ismeretlen szekvenciájú restrikciós fragmentumokat sokszorozunk meg. Hasonlít az RFLP-re, a két eljárás között a legfőbb különbség, hogy az RFLP-technika a restrikciós fragmentumhossz különbségeit mutatja, míg az AFLP a restrikciós fragmentumok meglétét vagy hiányát jelzi (Hajósné 1999). 


\subsubsection{Azonosításra alkalmas PCR alapú technikák}

\section{PCR-RFLP}

Az élesztőfajok elkülönítésére PCR-RFLP is alkalmazható. Ehhez konzervatív génszakaszokkal, például rRNS gének, illetve nem kódoló szakaszainak határszekvenciáival komplementer primerekkel PCR-t végünk. A leggyakrabban használt szakaszok az ITS1 és ITS2, ritkábban a D1/D2 szakasz (2. ábra). A PCR termék restrikciós enzimekkel való emésztése után, az így keletkező eltérő hosszúságú fragmentek gélen történő elválasztásával nyerhető tipizálásra alkalmas mintázat. Nagy hátránya a sztenderd módszer és egységes adatbázis hiánya (Deák 1998). További hátránya, hogy kisebb differenciációs kapacitásal rendelkezik, mivel a módszer nem tesz különbséget a közeli fajok között abban az esetben, ha kevés bázispárkülönbség van a vizsgált szekvenciák között és azok nem restrikciós helyre esnek (Teofanova et al. 2012).

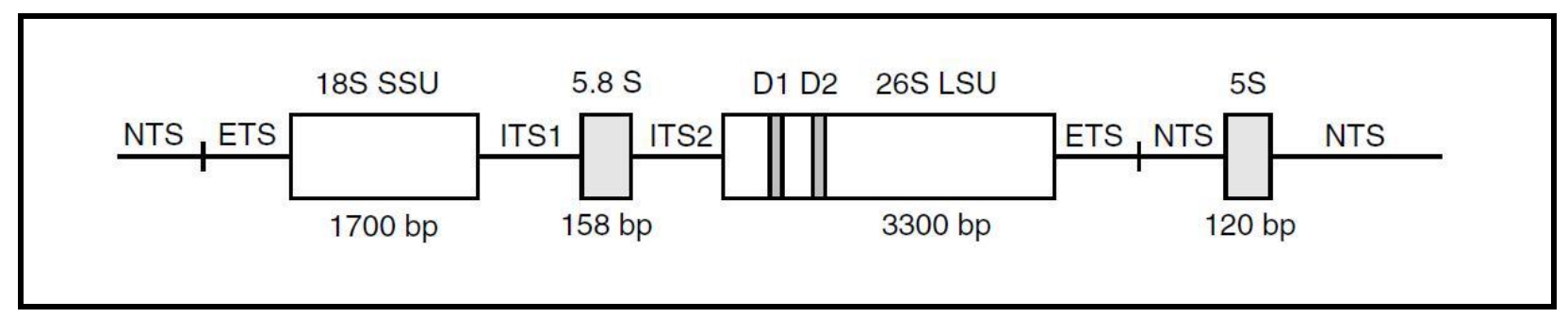

2. ábra. A sejtmagi rDNS szakaszai.

Az rRNS gének (rDNS) valamint az ITS és NTS szakaszok egymáshoz viszonyított elhelyezkedése a riboszómális géncsoportban (Deák 2008).

\section{Mikroszatellit primerrel végzett PCR (MP-PCR)}

Specifikus primerekkel olyan fragmenteket szaporítunk fel, melyeket agaróz gélben futtatva élesztőfajok és törzsek között diagnosztikus különbségeket mutató mintázatokat kapunk, restrikciós hasítás és DNS próbák nélkül is.

Egyszerü ismétlődő szakaszokat, például mini- és mikroszatellit szekvenciákat primerként használva, a PCR termékek közvetlen gélelektroforézisével élesztőgombatörzsek azonosítására alkalmas mintázatot kaphatunk. A módszert számos esetben sikeresen alkalmazták. A módszer egyszerüsége, gyorsasága és sikeres alkalmazásáról a szakirodalomban talált számos beszámoló miatt kísérleteimhez ezt a módszert választottam és az alábbiakban részletesebben bemutatom. A választást indokolja az is, hogy a többi módszerrel összehasonlítva az MP-PCR rendelkezik a legnagyobb diszkriminációs kapacitással (Belaj et al. 2003). 
Mikroszatellitek, egyszerű szekvencia ismétlődések (SSR) elszórtan fordulnak elő eukarióták genomjában. Ezek rövid szekvenciák, melyek véletlenszerüen ismétlődnek a DNSben, elhelyezkedésük az egyes fajokban eltérö. Az MP-PCR egy rendkívül érzékeny PCR-alapú technika, mely során a mikroszatellitek közti DNS régiókat vizsgáljuk. Az MP-PCR során a hibridizáció alacsony hőmérsékleten megy végbe, a kb. 15 bázispár hosszúságú primerek találomra kötődnek a megfelelő DNS szakaszhoz, így specifikus mintázatot adó reakciótermékeket kapunk (Deák 1998). Élesztőgomba törzsek elkülönítéséhez gyakran alkalmaznak olyan ismétlődő bázissorrendű primereket, mint például a (GAC) 5 vagy $(\mathrm{GTG})_{5}$ (Baleiras-Couto et al. 1996a, b; Caruso et al. 2002).

Ezt a technikát széleskörűen alkalmazzák élesztőgomba törzsek egymástól való megkülönböztetésére (Baleiras-Couto et al. 1996a). A PCR alapú tipizáló technikák élesztőgomba azonosításban való alkalmazhatóságát többen tanulmányozták és arra a következtetésre jutottak, hogy ez a PCR ujjlenyomat technika megfelel az alkalmazott oligonukleotid primertől függően a fajok közti vagy fajon belüli megkülönböztetésre (BaleirasCouto et al. 1996a). Baleiras Couto és munkatársai (1996a, b) szerint az MP-PCR, különösen a $(\mathrm{GTG})_{5}$ oligonukleotid primer használatával megbízhatóan alkalmazható akár fajon belüli megkülönböztetésre is.

Az MP-PCR technika során olyan primereket használunk, melyek komplementerek az ismétlődő szakaszokkal, így hozzájuk kötődve a köztük lévő különböző hosszúságú szakaszokat szaporítják fel (Mittal et al. 2009). Ezeket az eltérő hosszúságú szakaszokat agaróz gélelektroforézissel elkülönítve, majd etídium-bromiddal megfestve és UV fénnyel láthatóvá téve elkülöníthetjük egymástól a különböző mikroorganizmusokat.

Baleiras-Couto és munkatársai (1996a) majonéz és salátaöntetek előállítása során izolált élesztőgombatörzseket próbáltak API teszt felhasználásával azonosítani, de nem jártak sikerrel, viszont az MP-PCR $(\mathrm{GAC})_{5}$ és $(\mathrm{GTG})_{5}$ oligonukleotid primerek felhasználásával kiválónak bizonyult. Vizsgálataik során csak ez a módszer tette lehetővé, hogy a Zygosacchromyces nemzetség fajait elkülönítsék egymástól. Mivel ezzel a módszerrel a Z. bailii fajon belül még az egyes típusok is elkülöníthetők voltak egymástól és a romlott élelmiszerekből izolált törzsek megegyeztek a gyártóvonalról izoláltakkal, a szerzők még azt is felvetették, hogy a módszer alkalmas tömegesen előforduló élelmiszerromlás okainak visszakövetésére, sőt alkalmazható ipari környezetben a mikrobiológiai minőségbiztosítás monitorozása részeként, mint gyors azonosítási módszer. Egy másik tanulmányukkal összhangban a (GTG)5 primert valamivel hatékonyabbnak találták a (GAC) 5 primernél (Baleiras-Couto et al. 1996b). 
A (GAC) 5 és (GTG) 5 primereket sikeresen alkalmazták Yarrowia lipolytica törzsek fajon belüli elkülönítésére is (Palande et al. 2014).

Egy közelmúltban megjelent tanulmányban Ramírez-Castrillón és munkatársai (2014) arra hívták fel a figyelmet, hogy az élesztőgomba törzsek MP-PCR alapú csoportosítása nem teljes mértékben megbízható. Az egyes csoportok nem feltétlenül csak azonos fajhoz tartozó törzseket tartalmaznak és azonos fajhoz tartozó törzsek különböző csoportokba is kerülhetnek. $(\mathrm{GTG})_{5}$ és M13 primereket használtak, majd az eredményeket az LSU rRNS gén szekvenálásával nyert eredményekkel összehasonlítva ellentmondásokat tapasztaltak, így azt a következtetést vonták le, hogy a módszerrel számos esetben valószínüleg tévesen azonosítottak törzseket, ezzel alulbecsülve az élesztőgombák diverzitását.

\subsubsection{DNS szekvenálás}

Az élesztőgomba fajok és törzsek egymástól való elkülönítésének legpontosabb módja a felszaporított DNS szekvenálása. Szekvenálás során négy különböző reakcióelegyet állítanak össze, amik négyféle nukleotidon és polimeráz enzimen kívül jelöléssel ellátott didezoxinukleotidot is tartalmaznak. Amikor ezek a DNS szálhoz kapcsolódnak, a szintézis leáll, így különböző méretü DNS darabokat kapunk, melyek a gélben különböző sávokat adnak, ezeket összeolvasva megkapjuk a bázissorrendet (Deák 1998).

Ennek a PCR alapú, automata készülékeket alkalmazó szekvenálásnak és a szekvenciák összehasonlítását lehetővé tevő GenBank adatbázisnak köszönhetően a módszer egyre elterjedtebbé és rutinszerűen alkalmazhatóvá és az elmúlt néhány évtizedben a fajok azonosításának legmegbízhatóbb eszközévé vált. A riboszómális DNS szekvenciák a legfontosabbak az azonosításhoz, rendszerezéshez és filogenetikai tanulmányokhoz használt jellemzők közül (Valente et al. 1999). Az rDNS előnye, hogy minden élő szervezetben jelen van, ráadásul több kópia van belöle és rendelkezik konzervatív és variabilis részekkel is, amik szükségesek egy fajhoz tartozó törzsek és magasabb rendszertani csoportok egymástól való elkülönítéséhez. Leggyakrabban az ITS régiókat vagy a kis riboszómális alegység 18S rDNSének részleges vagy teljes szekvenciáját, vagy a nagy riboszómális alegység kb. 600 nukleotidból álló D1/D2 régióját használják, az élesztőgombák fajszintű azonosításában utóbbinak van nagy szerepe (Lopandic et al. 2006; Deák 2008). Kurtzman és Robnett (1998) gyakorlatilag az összes ismert aszkomikóta élesztőgomba D1/D2 szekvenciáját meghatározta, Fell és munkatársai (2000) pedig a bazidiomikóták ugyanezen szekvenciáit publikálták. 
Az élesztőgombák rendszerezése jelenleg jórészt az rDNS szekvenciák elemzésén alapszik (Kurtzman és Robnett 1998; Fell et al. 2000; Kurtzman és Fell 2006). Az ITS régiót is gyakran használják élesztőgombák azonosítására, de a legtöbb esetben a D1/D2 régió alkalmasabbnak bizonyult erre a célra (Kurtzman and Fell 2006). Schoch és munkatársai az ITS régiót ajánlották univerzális gomba „vonalkód”-ként (2012), közel rokon bazidiomikota élesztőgombák azonosításához. Scorzetti és munkatársai mindkét említett rDNS régió együttes vizsgálatát ajánlják (2002). A Yarrowia csoport fajainak azonosításának megbízható eszköze a D1/D2 és ITS régiók analízise (Knutsen et al. 2007). A D1/D2 régióban fajon belül általában 0-3 nukleotid-különbség fordul elő, 1\%-nál nagyobb eltérés különböző fajokra utal, ITS esetében pedig általában 0-4 nukleotid-különbség (0-1\%) fordul elő egy fajon belül (Kurtzman és Robnett 1998; Daniel et al. 2009). Mivel az ITS szekvenciák gyorsabban változnak, mint a kódoló régiók (Chen et al. 2000), jellemző, hogy az ITS régiók szekvenciái között nagyobb a különbség, mint a D1/D2 régiók szekvenciái között, azonban található a szakirodalomban néhány ellenpélda is. Fonseca és munkatársai (2000) figyelték meg Cryptococcus fajok között ezt a ritka jelenséget. A Yarrowia csoporttal kapcsolatban hasonló esetet dokumentáltak két C. alimentaria (CBS 10149 és CBS 10151) törzs között. D1/D2 régióik között 9 nukleotid különbséget találtak, ITS szekvenciájuk viszont csak egy nukleotidban különbözött, de 100\%-os DNS-DNS reasszociációjuk bebizonyította, hogy egy fajhoz tartoznak (Knutsen et al. 2007). Lachance és munkatársai (2003) aszkuszokat és aszkospórákat figyeltek meg olyan párosodó Clavispora lusitanieae törzsek között, melyek D1/D2 szekvenciái között 32 szubsztitúciót detektáltak. Néhány kivételtől eltekintve az élesztőgombák azonosításához az esetek túlnyomó többségében (különösen aszkomikóták esetében) elegendő a D1/D2 szekvencia meghatározása (Kurtzman és Robnett 1998; Fell et al. 2000).

\subsection{A Yarrowia lipolytica szelektív izolálása}

Különböző élesztőgombák izolálásához használnak specifikus, differenciáló és szelektív tápközegeket, melyek gátló anyagokat, megkülönböztető festékeket vagy kiválasztott szénés/vagy nitrogénforrásokat tartalmaznak. Élelmiszer-eredetű élesztőgombák kimutatására alkalmas tápközegek fejlesztésekor hasonló elveket követnek (Deák 1998).

A Y. lipolytica kimutatásához három különböző módszert találtam a szakirodalomban. Lin és Fung (1985) kísérleteik alapján arra a következtetésre jutottak, hogy a $Y$. lipolytica hatékonyan elkülöníthető más élesztőgombáktól 0,1\% kristályibolyát vagy 0,004\% Malachit zöld festéket tartalmazó YM agaron, mivel ezeken jellegzetes, durván gyürt telepeket képez. Carreira 
és Loureiro (1998) leírt egy a Y. lipolytica kimutatására alkalmas differenciáló táptalajt, ami az említett faj azon egyedi tulajdonságán alapult, hogy képes tirozinból barna pigmenteket képezni.

Ezeknek a módszereknek leírásakor a $Y$. lipolytica volt a csoport egyetlen ismert tagja, és mint azóta kiderült, a fenotípusos tulajdonságokon alapuló azonosítása nem megbízható. A csoport számos tagja nem különíthető el egymástól fenotípusos jellemzőik alapján (köztük a $Y$. lipolytica sem), így az említett módszerek semmiképp sem alkalmazhatók a $Y$. lipolytica elkülönítésére, legfeljebb a csoport tagjainak többi élesztőgombától való megkülönböztetésére. Ráadásul gyakran az élesztőgombák, köztük a Yarrowia csoport tagjai a baktériumokhoz képest olyan kis számban fordulnak elő az élelmiszerekben, hogy izolálásuk elődúsítás nélkül sokszor rendkívül nehézkes. Ezek miatt az említett módszerek hatékonysága megkérdőjelezhető. Még nem ismert olyan módszer, mellyel hatékonyan, nagy számban lehetne a Yarrowia csoport tagjait izolálni.

\subsection{A Yarrowia lipolytica fenotípusos elkülönítési lehetőségei a Yarrowia csoport többi tagjától}

Az aszkomikóták és bazidiomikóták megkülönböztetésének egyik eszköze az ureáz-teszt, ami bazidiomikóták esetében pozitív, aszkomikóták esetében a Taphrinomycotinákat leszámítva negatív. Korábban sokáig kivételnek tekintették a $Y$. lipolytica-t, mivel aszkomikóta, de pozitív ureáz reakciót adott (Kurtzman 1998). Booth és Vishniac (1987) azonban negatív ureáz reakciót tapasztalt a típustörzs vizsgálatakor, amit Péter és Deák (1991) is megerősítettek és számos más $Y$. lipolytica törzsre is kiterjesztettek. Utóbbi szerzők bebizonyították, hogy a $Y$. lipolytica által a Christensen's urea agaron tapasztalt színváltozás fals pozitív eredmény, mivel az nem ureázaktivitás miatt következik be, hanem az agar nem-specifikus lúgosodás miatt urea hozzáadása nélkül is elszíneződik és téves eredményt ad. Néha még napjainkban is tévesen, a csoport többi tagjától való fenotípusos elkülönítési lehetőségként említik a $Y$. lipolytica ureáz-aktivitását (Galán-Sánchez et al. 2014), ez azonban nem helytálló.

A C. galli leírásában (Péter et al. 2004) található információ szerint vitaminmentes táplevesben képes szaporodni, a legutóbbi monográfiában is ez az információ szerepel (Kurtzman et al. 2011), és azóta is a csoport többi tagjától való elkülönítésére alkalmas tulajdonságként említik (Michely et al. 2013; Galán-Sánchez et al. 2014).

Michely és munkatársai (2013) összehasonlító élettani teszteket végeztek a Yarrowia csoport tagjain. Többek között vizsgálták 31 szénforrás asszimilációját (harmincat API ID32 C teszttel és a fruktózt mikrotiter lemezen). Kilenc faj típustörzsét vizsgálták és felhívták rá a 
figyelmet, hogy a fajonként egyetlen törzs vizsgálatával a kapott eredményeik nem biztos, hogy megfelelően reprezentálják a fajok asszimilációs képességeit. Bevezetésükben azt írják, hogy a C. hispaniensis és $C$. oslonensis képesek asszimilálni a galaktózt és a szorbózt, míg a csoport többi tagja nem, vagy csak gyengén, és a $C$. hispaniensis köztük az egyetlen, mely képes a trehalóz asszimilációjára. Ezek az információk azonban nem egyeznek teljes mértékben a monográfiában található adatokkal. Említik a C. galli egyedüli vitaminmentes közegben való szaporodóképességét. Eredményeik néhány esetben ellentmondanak a CBS adatbázisban és a monográfiában található információknak. Ezeket az ellentmondásos tulajdonságokat mikrotiter lemezen is tesztelték, az így kapott eredmények megegyeztek az API teszttel kapott eredményeikkel.

A fentiekből látszik, hogy a csoport tagjainak fiziológiai tulajdonságairól a szakirodalomban található információk esetenként ellentmondásosak, nem reprezentatívak, esetleg tévesek lehetnek, így azok alapján nem lehet a $Y$. lipolytica-t megbízhatóan elkülöníteni a Yarrowia csoport többi tagjától, és azok közül néhányat egymástól sem. 


\section{CÉLKITÜZÉSEK}

A kutatás célja a Yarrowia csoport sokféleségének vizsgálata különböző élelmiszerekben, a Yarrowia csoportba tartozó Yarrowia és Yarrowia-rokon törzsek nagyszámban való begyüjtéséhez hatékony izolálásra alkalmas módszer kidolgozása, az izolált törzsek csoportosítása fenotípusos tulajdonságok alapján, majd a Yarrowia komplexbe tartozó izolátumok elkülönítése fiziológiai tesztekkel és azok molekuláris módszerrel való azonosítása, taxonómiai besorolásuk elvégzése.

Célul tüztem ki, hogy

- hatékony izolálási módszert dolgozzak ki a potenciálisan romlást okozó Yarrowia csoportba tartozó élesztőgomba törzsek izolálására különböző élelmiszerekből (nyers húsból, tejből, tejtermékekből);

- az izolált törzsek közül kiválasszam a hexadekán asszimilációjára képes törzseket;

- majd ezek közül fiziológiai tesztek alkalmazásával különítsem el a Yarrowia csoportba tartozókat;

- a Yarrowia csoportba tartozó fajokat DNS szekvenciájuk alapján tipizáljam és azonosítsam;

- megvizsgáljam a szekvencia összehasonlítással azonosított élesztőgomba fajok fenotípusos elkülönítési lehetőségeit.

- További célom volt a DNS szekvenáláson alapuló módszerrel azonosított Yarrowia komplex csoportba tartozó élesztőgomba törzsek fajspektrumának és az izolálási forrásul szolgáló élelmiszerek körének összehasonlítása és a termék-specifikus előfordulás vizsgálata;

- a kísérletek során felmerülő esetleges újabb kérdések, problémák megoldása.

A kísérletek során felmerült további célok:

- $\quad$ az újonnan kidolgozott izolálási módszer hatékonyságának fokozása;

- a Yarrowia csoport tagjainak élelmiszerek romlásához potenciálisan hozzájáruló képességeinek tesztelése;

- a Yarrowia csoportba tartozó, ismert teleomorf alakkal nem rendelkező fajok aszkosporulációjának tesztelése;

- hexadekán pozitív, de nem a Yarrowia csoportba tartozó élesztőgombák csoportosítása, fajszintű azonosítása. 
DOI: 10.14267/phd.2015033 


\section{ANYAGOK ÉS MÓDSZEREK}

\subsection{Anyagok}

\subsubsection{A feldolgozott minták}

Az alábbi táblázatban foglaltam össze, hogy milyen élelmiszermintát milyen számban dolgoztam fel, és azokból mennyi élesztőgombatörzset izoláltam és vizsgáltam (1. táblázat).

1. táblázat. Felhasznált élelmiszerminták és a belőlük izolált, vizsgált élesztőgombák száma

\begin{tabular}{lcc}
\hline \multicolumn{1}{c}{ Minta } & Mintaszám & Izolátumok száma \\
\hline Darált sertéshús & 32 & 162 \\
Darált marhahús & 26 & 126 \\
Darált marha- és sertéshús keveréke & 2 & 10 \\
Pulyka húspép & 1 & 7 \\
Pulyka darált hús & 1 & 5 \\
Pulyka mellfilé & 1 & - \\
Gyorsfagyasztott pulykahús & 2 & 11 \\
Oldalas & 1 & 1 \\
Nyers tej & 40 & 218 \\
Sajt & 9 & 57 \\
Túró & 18 & 229 \\
\hline Összesen & 133 & 826 \\
\hline
\end{tabular}

\subsubsection{Referencia élesztőgombatörzsek}

A 2. táblázatban a Yarrowia csoportba tartozó vizsgált referenciatörzsek találhatók. 
2. táblázat. A Yarrowia csoportba tartozó vizsgált referenciatörzsek

\begin{tabular}{|c|c|}
\hline Élesztőgombafajok & Törzsek \\
\hline Candida alimentaria & CBS10151 ${ }^{\mathrm{T}}$ \\
\hline \multirow[t]{9}{*}{ Candida galli } & NCAIM Y.00639 \\
\hline & NCAIM Y.00654 \\
\hline & NCAIM Y.01482 \\
\hline & NCAIM Y.01483 \\
\hline & NCAIM Y.01484 \\
\hline & NCAIM Y.01486 \\
\hline & NCAIM Y.01488 \\
\hline & NCAIM Y.01489 \\
\hline & A249/hex4 \\
\hline Candida hollandica & $\mathrm{CBS} 4855^{\mathrm{T}}$ \\
\hline Candida hispaniensis & NRRL4-5580 \\
\hline Candida oslonensis & CBS10146 \\
\hline Candida phangngensis & CBS $10407^{\mathrm{T}}$ \\
\hline \multirow[t]{13}{*}{ Yarrowia deformans } & NCAIM Y.2005 \\
\hline & A248/hex4 \\
\hline & A248/hex 5 \\
\hline & A248/hex6 \\
\hline & A249/hex2 \\
\hline & A249/hex3 \\
\hline & A249/hex6 \\
\hline & A249/hex 7 \\
\hline & A249/hex 9 \\
\hline & A249/hex 10 \\
\hline & A249/hex 12 \\
\hline & A251/hex 2 \\
\hline & A251/hex 5 \\
\hline Yarrowia keelungensis & $\mathrm{CBS} 11062^{\mathrm{T}}$ \\
\hline
\end{tabular}


2. táblázat. A Yarrowia csoportba tartozó vizsgált referenciatörzsek (folytatás)

\begin{tabular}{|c|c|}
\hline Élesztőgombafajok & Törzsek \\
\hline \multirow[t]{22}{*}{ Yarrowia lipolytica } & NCAIM Y.00062 \\
\hline & NCAIM Y.00063 \\
\hline & NCAIM Y.00161 \\
\hline & NCAIM Y.00284 \\
\hline & NCAIM Y.00587 \\
\hline & NCAIM Y.00588 \\
\hline & NCAIM Y.00589 \\
\hline & NCAIM Y.00590 \\
\hline & NCAIM Y.00591 ${ }^{\mathrm{T}}$ \\
\hline & NCAIM Y.00592 \\
\hline & NCAIM Y.00593 \\
\hline & NCAIM Y.00594 \\
\hline & NCAIM Y.00595 \\
\hline & NCAIM Y.00596 \\
\hline & NCAIM Y.00597 \\
\hline & NCAIM Y.00759 \\
\hline & NCAIM Y.00879 \\
\hline & NCAIM Y.01087 \\
\hline & NCAIM Y.01267 \\
\hline & A248/hex3 \\
\hline & A249/hex1 \\
\hline & A249/hex11 \\
\hline \multirow[t]{4}{*}{ Yarrowia yakushimensis } & $\mathrm{JCM} 12782^{\mathrm{T}}$ \\
\hline & NCAIM Y.02049 \\
\hline & NCAIM Y.02050 \\
\hline & NCAIM Y.02052 \\
\hline
\end{tabular}

T: típustörzs;

NCAIM: Mezőgazdasági és Ipari Mikroorganizmusok Nemzeti Gyüjteménye (National

Collection of Agricultural and Industrial Microorganisms), Budapest;

CBS: Centraalbureau voor Schimmelcultures, Utrecht, Hollandia;

NRRL: Culture Collection, National Center for Agricultural Utilization Research, Peoria, IL USA;

JCM: Japan Collection of Microorganisms, Tsukuba, Japán 
A 2. táblázatban szereplö, Yarrowia csoportba tartozó törzseken kívül kontrolként használtam pigmenttermelés és zsírbontás vizsgálatához, valamint glükóz erjesztésének teszteléséhez a Saccharomyces cerevisiae NCAIM Y.00801 ${ }^{\mathrm{T}}$ törzset, ferdeagaros nitrát teszthez pedig az Ogataea histrianica ZIM $2463^{\mathrm{T}}$ törzset.

\subsubsection{Felhasznált tápközegek, oldatok}

Az alábbiakban felsorolt tápközegek és oldatok összetétele az M1 mellékletben található.

\section{Az izolátumok fenntartásához használt ferdeagar}

2\%-os malátakivonat agar

\section{Dúsításhoz, izoláláshoz felhasznált tápközegek}

Glükóz-pepton-élesztőkivonat agar (GPY)

Módosított Yarrowia dúsító tápleves $(\mathrm{pH}=3,5)$

Rose Bengal Chloramphenicol (RBC, MERCK, product no.: $1.00 .467, \mathrm{pH}=7,2$ )

Yarrowia dúsító tápleves $(\mathrm{pH}=3,4-3,6)$

\section{Fiziológiai tesztekhez használt tápközegek}

Cikloheximid rezisztencia vizsgálatához használt tápleves

Custers-féle kalcium-karbonátos táptalaj (glükózból való savképzés vizsgálatára)

Diazonium Blue B reagens

Ecetsavas (1\%) táptalaj (ecetsavtürés vizsgálatához)

Nitrát agar $(\mathrm{pH}=5,9-6)$ 
Glükóz-pepton-élesztőkivonat ferdeagar (GPY)

Keményítő képzésének vizsgálatához használt agar

Lugol-oldat (keményítőképzés vizsgálatához)

Urea Rapid Broth (urea hidrolízis vizsgálatához használt tápleves, pH=6,9)

Vitaminmentes tápleves

„Yeast Carbon Base” (nitrogénforrás asszimilációhoz)

„Yeast Nitrogen Base” (szénforrás asszimilációhoz)

\section{A Yarrowia csoport tagjainak az élelmiszerek romlásához potenciálisan hozzájáruló tulajdonságainak teszteléséhez használt tápközegek}

Fehérjebontás (zselatinfolyósítás) vizsgálatához használt tápközeg

Olívaolajos agar (zsírbontás vizsgálatához) (Gorodkowa agar 5\% olívaolajjal)

Yarrowia lipolytica differenciáló táptalaj (pigment-termelés vizsgálatához, pH=7,2)

\section{Spóráztatáshoz használt ferdeagarok}

Acetát agar (Adam’s-féle élesztőspóráztatáshoz)

Burgonya-dextróz agar (PDA)

Élesztőkivonat-malátakivonat agar (YM)

Élesztőkivonat-szacharóz agar (YES)

Glükóz-pepton-élesztőkivonat agar (GPY)

Módosított glükóz-pepton-élesztőkivonat agar (GPYA) 
Nitrát agar $(\mathrm{pH}=5,9-6)$

Kukoricaliszt agar (CM)

$2 \%$ malátakivonat agar (MEA)

„Restricted Growth” agar (RG)

V8 agar $(\mathrm{pH}=6,8)$

،'Spezieller Nährstoffarmer Agar'” (SNA)

„Yeast-Carbon Base” agar (YCB)

„Yeast-Carbon Base” agar kiegészítve 0.01\% ammónium-szulfáttal (YCBAS)

\subsubsection{Molekuláris vizsgálatokhoz felhasznált anyagok, oldatok, oligonukleotid primerek}

Qiagen Plant mini kit: oszlopok és a kit részeként forgalmazott odatok, enzimek

Dream Taq polimeráz enzim (Thermo Scientific)

Puffer, polimeráz használatához (Thermo Scientific)

Dezoxiribonukleozid-trifoszfátok (Thermo Scientific): dNTP mix: egyenlő arányban (10mM) tartalmazza a négy nukleotidot (dATP, dCTP, dGTP, dTTP)

Primerek (Metabion)

3. táblázat. PCR-hez használt primerek

\begin{tabular}{|l|l|l|}
\hline \multicolumn{1}{|c|}{ Primer } & \multicolumn{1}{c|}{ Szekvencia } & \multicolumn{1}{c|}{ Alkalmazás } \\
\hline$(\text { GAC })_{5}$ & 5'-GACGACGACGACGAC-3' & MP-PCR \\
\hline$(\text { GTG })_{5}$ & 5'-GTG GTG GTG GTG GTG-3' & MP-PCR \\
\hline NL1 & 5'-GCATATCAATAAGCGGAGGAAAAG-3' & D1-D2-PCR \\
\hline NL4 & 5'-CCGTCTTGAAACACGGACC-3' & D1-D2-PCR \\
\hline ITS1 & 5'-TCCGTAGGTGAACCTGCGG-3' & ITS-PCR \\
\hline ITS4 & 5'-TCCTCCGCTTATTGATATGC-3' & ITS-PCR \\
\hline
\end{tabular}


Agaróz (Sigma A9539)

1 X Tris-Bórsav-EDTA (TBE) futtató puffer

Etídium-bromid törzsoldat

DNS molekulaméret sztenderdek

Thermo Scientific Gene Ruler 100 bp SM0321 (fragmentméretek: 3000, 2000, $1500,1200,1000,900,800,700,600,500,400,300,200,100$ bp)

Sigma-Aldrich Marker 2000 bp P9577 (fragmentméretek: 2000, 1500, 1000, 750, $500,300,150,50 \mathrm{bp})$

\subsubsection{Eszközök, müszerek}

Stomacher-készülék (KOPAKI)

Centrifuga (Hermle Z383K)

PCR készülék (Bio-Rad C1000 Thermal Cycler)

Horizontális elektroforézis készülék (SzBKI)

UV-transzilluminátor készülék (Ultra-Lum)

Fényképezőgép (Nikon, Coolpix 995)

\subsection{Módszerek}

\subsubsection{Minták beszerzése, feldolgozása}

Vizsgálataim során különböző nyers húsokat, (föként sertés- és marhahúst, kisebb mennyiségben pulykahúst) nyers tejet, lejárt minőségmegőrzési idejü sajtokat és túrót használtam fel. A húsminták többségét egy minőségellenőrző laboratóriumból szereztem be, néhányat üzletben vásároltam. A nyers tejminták állattartóktól vagy kereskedelemből származtak, a sajtmintákat üzletben vásároltam. A túróminták egy részét egy laboratóriumtól 
kaptam, ahol tárolási kísérleteket végeztek velük, lejárt a minőség-megőrzési idejük, más részüket üzletben vásároltam. Utóbbiakból frissen is és a minőség-megőrzési idő lejárta után is mintát vettem, hogy azokból élesztőgombákat izoláljak. A sajtok esetében kivártam a fogyaszthatósági idő lejártát, miközben hűtőszekrényben tároltam őket. A friss minták feldolgozását lehetőség szerint azonnal, de legfeljebb 24 órán belül elkezdtem.

\subsubsection{Szelektív módszer keresése Yarrowia csoportba tartozó törzsek izolálásához}

\subsubsection{Dúsítás}

Az élesztőgombák sokszor a baktériumokhoz képest kisebb számban találhatók meg az élelmiszerekben. Annak érdekében, hogy a baktériumok szaporodását háttérbe szorítsuk, olyan körülményeket kell biztosítani a dúsítás során, mely az élesztőgombáknak, azon belül is a Yarrowia csoport tagjainak kedvez. Ezért egy olyan Yarrowia dúsító táplevest készítettem, melynek pH értéke 3,6 (ezzel a baktériumok többségének szaporodása gátolható), és olyan specifikus szénforrást (hexadekánt) tartalmaz, amit a Yarrowia csoport tagjain kívül az ismert élesztőgombafajoknak csak kis hányada képes asszimilálni (így a legtöbb élesztőgomba szaporodásához hiányzik a szénforrás), ezáltal elősegítve a Yarrowia csoportba tartozó törzsek dominanciáját a dúsító levesben, lehetővé téve nagy számban történő izolálásukat.

A dúsítás első lépéseként 18 húsminta esetében 10 grammot, a tejminták esetében mintánként $10 \mathrm{ml}$-t inokuláltam $100 \mathrm{ml}$ Yarrowia-dúsító táplevesbe $250 \mathrm{ml}$-es lombikba. 48 húsminta esetében mintánként 10 grammot 2 percig homogenizáltam $90 \mathrm{ml}$ 0,1\%-os peptonvízben Stomacher-készülék segítségével (KOPAKI), majd a homogenizátumból 1 ml-t pipettáztam $5 \mathrm{ml}$ Yarrowia-dúsító táplevesbe $16 \mathrm{~mm}$ átmérőjủ kémcsövekbe. Túró- és sajtminták esetében mintánként 10 grammot 2 percig homogenizáltam $90 \mathrm{ml}$ 0,1\%-os peptonvízben Stomacher-készülék segítségével (KOPAKI), majd a homogenizátumból 10 ml-t pipettáztam 100 $\mathrm{ml}$ Yarrowia-dúsító táplevesbe $250 \mathrm{ml}$-es lombikba. A lombikokat horizontális rázógépben (100 rpm), a kémcsöveket kémcsőforgató készüléken (30 rpm) inkubáltam $25^{\circ} \mathrm{C}$-on hét napig.

A dúsítás második lépéseként hét nap után az első dúsító folyadékból 0,1 ml-t oltottam át azonos összetételü tápleves 5 ml-ébe, 16 mm-es kémcsövekbe, amit kémcsőforgató készüléken (30rpm) inkubáltam $25{ }^{\circ} \mathrm{C}$-on. Újabb hét nap elteltével egy harmadik, az előzővel megegyező dúsító lépést alkalmaztam. 


\subsubsection{Szélesztés RBC agarra}

A három-lépéses, három hétig tartó dúsítást követően peptonvízzel hattagú tizedelő hígítási sort készítettem. $10^{-4}, 10^{-5}$ és $10^{-6}$ hígítási tagokból 0,1 ml-t szélesztettem Rose Bengal Chloramphenicol (RBC) táptalaj felszínére, majd egy hétig $25^{\circ} \mathrm{C}$-on inkubáltam sötétben.

\subsubsection{Izolálás}

Az RBC lemezeken kinőtt, minden egyes eltérő morfológiájú élesztőgomba telepet izoláltam. Ismételt glükóz-pepton-élesztőkivonat (GPY) agar lemezekre történő szélesztéssel, 25 ${ }^{\circ} \mathrm{C}$-on 7 napig inkubálva tiszta tenyészeteket állítottam elő.

\subsubsection{A tenyészetek fenntartása}

A törzsek fenntartása liofilezéssel és $2 \%$-os maláta ferdeagaron történt $4{ }^{\circ} \mathrm{C}$-on. A $2 \%$-os maláta ferdeagaron fenntartott tenyészeteket évente átoltottam.

\subsubsection{Hexadekán-asszimiláló törzsek kiválasztása}

A vizsgálatok előtt egyedüli szénforrásként hexadekánt tartalmazó táplevesbe való inokulálással ellenőriztem, hogy az izolált törzsek valóban képesek-e a hexadekánt asszimilálni. A vizsgálathoz 48 órás tenyészeteket használtam. Steril desztillált vízzel „2+”-es mikrobaszuszpenziót ${ }^{1}$ készítettem, melyből 0,1 ml-t inokuláltam $5 \mathrm{ml}$, 0,5\% hexadekánt tartalmazó „Yeast-Nitrogene-Base” (YNB) táplevesbe, $16 \mathrm{~mm}$-es kémcsőbe, amit kémcsőforgató készüléken (30 rpm) inkubáltam három hétig $25{ }^{\circ} \mathrm{C}$-on. A szaporodást hetente értékeltem, erősségét a lábjegyezetben ${ }^{1}$ leírtaknak megfelelően határoztam meg.

\footnotetext{
${ }^{1}$ A szuszpenzió töménységét vagy a szaporodás mértékét szemmel becsültem meg úgy, hogy a kémcsőkeverővel homogénné tett mikrobaszuszpenziót tartalmazó kémcsöveket Wickerhamkártya (fehér lap, melyen $0,75 \mathrm{~mm}$ vastagságú, egymástól $5 \mathrm{~mm}$ távolságra elhelyezkedő vízszintes fekete vonalak találhatók) elé helyeztem. A szuszpenzió „1+” -es akkor, ha a vonalak egymástól elkülöníthetők, de azok szélei elmosódottak; „2+”, ha elmosódott sávokat látunk; „3+”, ha a vonalak egyáltalán nem láthatók (Kurtzman et al. 2011).
} 


\subsubsection{A Yarrowia-dúsító tápleves módosítása a nagyobb hatékonyság érdekében}

Bár a kellő számú élesztőgomba törzs begyüjtéséhez és a kutatási munkatervben vállalt célok eléréséhez megfelelő a fent említett dúsító tápleves, megpróbáltam még hatékonyabbá tenni az izolálási módszert. A Yarrowia-dúsító tápleves módosításának célja az volt, hogy fokozzam a hexadekán-pozitív élesztőgomba törzsek izolálásának hatékonyságát, kiküszöbölve az első dúsító leves mikrobák által szénforrásként felhasználható citromsav-tartalma miatti hexadekán-negatív törzsek izolálását.

A módosított tápleves elkészítéséhez felhasznált puffer oldat kálium-dihidrogén-foszfátot és foszforsavat tartalmazott, így a korábbival szemben (ami a mikrobák által felhasználható szénforrásként citromsavat tartalmazott) a hexadekánon kívül nem tartalmazott más szénforrást. Emiatt feltételezhető volt, hogy a módosított Yarrowia-dúsító tápleves használatával nagyobb arányban lehet hexadekán-pozitív törzseket izolálni, mint a korábbi Yarrowia-dúsító levessel.

\subsubsection{A Yarrowia csoportba tartozó törzsek elkülönítése fiziológiai tesztekkel}

A hexadekán-asszimilációra képes törzsek közül fiziológiai tesztekkel különítettem el a Yarrowia csoport tagjait. 48 órás tenyészetekkel dolgoztam. Először a nitrátasszimiláló- és glükózerjesztő-képességüket vizsgáltam, előbbit ferde nitrát agarra történő leoltással, utóbbihoz pedig steril desztillált vízzel készített „2+”-es mikrobaszuszpenzióból 0,1 ml-t oltottam 2\% glükóztartalmú táplevesbe, Durham-csövet tartalmazó 16 mm-es kémcsövekbe. Pozitív kontrolként a S. cerevisiae típustörzsét (NCAIM Y.00801 ${ }^{\mathrm{T}}$ ) használtam.

Mindkét teszthez $25{ }^{\circ} \mathrm{C}$-on inkubáltam a kémcsöveket. Előbbit 48 óra után olvastam le, a nitrát asszimilációját a zöld színü agar kékülése jelezte, utóbbit 3 hétig rendszeresen leolvastam, pozitív eredményt a Durham-csőben megjelenő gáz jelzett.

Mivel a Yarrowia csoport ismert tagjai nem képesek sem a glükóz erjesztésére sem a nitrát asszimilációjára, csak azoknál a törzseknél vizsgáltam 30 szénforrás asszimilációját API ID 32C teszt segítségével, melyek mindkét említett tesztre negatív eredményt adtak. A teszt 30 szénforrás (galaktóz, szacharóz, N-acetil-D-glükózamin, DL-laktát, L-arabinóz, cellobióz, raffinóz, maltóz, trehalóz, 2-keto-D-glükonát, metil- $\alpha$-D-glükozid, D-mannit, laktóz, myo-inozit, D-szorbit, D-xilóz, D-ribóz, glicerin, L-ramnóz, palatinóz, eritrit, melibióz, glükuronát, melezitóz, glükonát, levulinát, glükóz, L-szorbóz, glükózamin, eszkulin) asszimilációjának, és $0,1 \%$ cikloheximid-türő képesség vizsgálatát teszi lehetővé. 
A Yarrowia csoport tagjainak fent említett fiziológiai tulajdonságairól összefoglaló táblázatot készítettem a fajleírásokban, a CBS adatbázisban, legújabb kiadású monográfiában (Kurtzman et al. 2011) található, valamint saját adatok alapján (4. táblázat). Hiányzó vagy egymásnak ellentmondó adatok esetében az adott faj adott fiziológiai tulajdonságát magam teszteltem a rendelkezésemre álló összes, adott fajhoz tartozó törzsön, beleértve a típustörzset, a legújabb monográfiában (Kurtzman et al. 2011) leírtak szerint. Az általam izolált hexadekánasszimiláló törzsekkel végzett tesztek eredményeit a táblázat összegző sorában található adatokkal összevetve különítettem el a Yarrowia csoport tagjait.

4. táblázat. A Yarrowia csoport tagjainak nitrát asszimilációjának, glükóz erjesztésének és API ID32C teszttel vizsgálható fiziológiai tulajdonságainak összefoglaló táblázata (nem tartalmazza a kutatás e szakaszában még leíratlan fajokra vonatkozó adatokat)

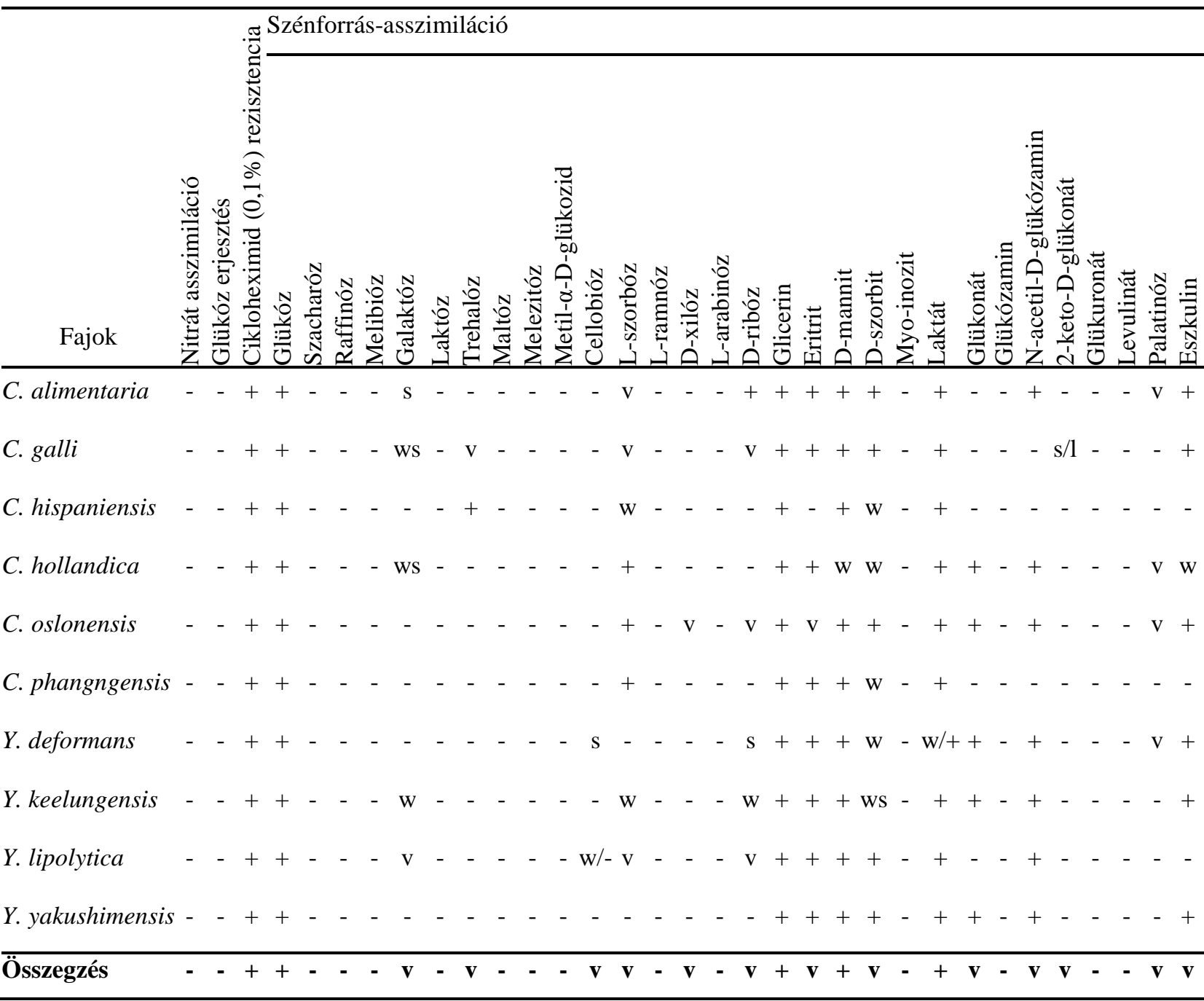

w: gyenge szaporodás; s: lassú szaporodás; 1: késleltetett szaporodás; v: változó 


\subsubsection{A Yarrowia csoportba tartozó törzsek csoportosítása MP-PCR módszerrel}

A fent említett módszer segítségével elkülönített Yarrowia csoportba tartozó élesztőgombákat MP-PCR segítségével kapott mintázatuk alapján csoportokba soroltam.

\subsubsection{DNS izolálás}

A DNS izoláláshoz 48 órás GPY ferdeagar tenyészeteket használtam. A tenyészetekből 20-30 $\mu \mathrm{g}$ sejttömeget steril spatulával PCR eppendorf csövekbe helyeztem, és a Qiagen kit segítségével izoláltam a DNS-t a gyártó utasításait követve.

\subsubsection{MP-PCR}

A PCR reakciókat $22 \mu 1$ reakcióelegyben hajtottam végre, amely 0,4 $\mu 1$ Dream taq DNS polimerázt (Thermo Scientific; $2 \mathrm{U} / \mu \mathrm{l}$ ), $2 \mu \mathrm{l}$ dezoxinukleozid-trifoszfát (dNTP) elegyet (nukleozidonként $2 \mathrm{mM}$ törzsoldatból), $2 \mu \mathrm{l}$ (GAC) 5 primert (10 $\mu \mathrm{M}$; Metabion), $2 \mu$ lízszeres koncentrációjú reakció puffert (Thermo Scientific) és $2 \mu 1$ DNS izolátumot tartalmazott. A DNS sokszorosítását Bio-Rad $\mathrm{C} 1000^{\mathrm{TM}}$ Thermal Cycler típusú PCR készülékkel végeztem a következő paraméterekkel: $95{ }^{\circ} \mathrm{C}$-on 3 percig tartott a bevezető denaturáció, amit 30-szor ismételt $96{ }^{\circ} \mathrm{C}$-on történő, 30 másodpercig tartó denaturáció, 35 másodpercig tartó $59{ }^{\circ} \mathrm{C}$-on történő primer kötődési és $72{ }^{\circ} \mathrm{C}$-on történő 55 másodpercig tartó lánchosszabbítási szakaszból álló ciklus követett. A folyamatot egy $72{ }^{\circ} \mathrm{C}$-on történő 30 másodpercig tartó lánchosszabbítás, majd 30 másodpercig tartó $12{ }^{\circ} \mathrm{C}$-on történő hütés zárta le.

\subsubsection{Gélelektroforézis és a kapott mintázat értékelése}

Az MP-PCR során felszaporított DNS-fragmentek gélelektroforézise etídium-bromidot tartalmazó 1,2\%-os agaróz gélben (Sigma) történt, horizontális futtatókádban (SzBKI), 1x-es TBE pufferben, 8 vagy 14 lépcsős DNS markerrel (Thermo Scientific Gene Ruler 100 bp SM0321 vagy Sigma-Aldrich Marker 2000 bp P9577), 5V/cm feszültséggel. Futtatás után a gélt UV fénnyel megvilágítottam (Ultra-Lum transzilluminátor), és a kapott mintázatokat fényképezőgéppel (Nikon) dokumentáltam. Az így kapott mintázatok alapján csoportosítottam a törzseket. 


\subsubsection{A Yarrowia csoport tagjainak fajszintü azonosítása molekuláris módszerrel}

A törzsek fajszintű azonosítása céljából csoportonként néhány törzsböl a következőkben részletezett módon felszaporítottam a riboszómális RNS nagy alegységét kódoló gén D1/D2 szakaszát, majd azok szekvenciáját meghatároztattam, és a kapott szekvenciákat a GenBank adatbázisban található referencia szekvenciákkal összehasonlítottam a BLAST 2.2.28 program segítségével. Ha a vizsgálat nem adott egyértelmü választ, akkor elvégeztem az ITS régiók szekvenálását és analízisét is.

\subsubsection{A 26S rRNS-t kódoló gén D1/D2 régiójának megsokszorozásához használt PCR reakció paraméterei}

A PCR reakciókat $22 \mu 1$ reakcióelegyben hajtottam végre, amely 0,4 $\mu 1$ Dreamtaq DNS polimerázt ( $2 \mathrm{U} / \mu \mathrm{l}), 2 \mu \mathrm{l}$ dezoxinukleozid-trifoszfát (dNTP) elegyet ( $2 \mathrm{mM}$ nukleozidonként), 1 $1 \mu$ l-t a $10 \mu \mathrm{M}$-os NL1 és NL4 primerekből (Metabion), $2 \mu 1$ tízszeres koncentrációjú reakció puffert (Thermo Scientific) és $2 \mu 1$ DNS izolátumot tartalmazott. A DNS felszaporítását Bio-Rad $\mathrm{C} 1000^{\mathrm{TM}}$ Thermal Cycler típusú PCR készülékkel végeztem a következő paraméterekkel: $95{ }^{\circ} \mathrm{C}$ on 3 percig tartott a bevezető denaturálás, amit 30-szor ismétlődő $95{ }^{\circ} \mathrm{C}$-on történő, 30 másodpercig tartó denaturáció, 35 másodpercig tartó $57{ }^{\circ} \mathrm{C}$-on történő primer kötődési és $72{ }^{\circ} \mathrm{C}$ on történő 45 másodpercig tartó lánchosszabbítási szakaszból álló ciklus követett. A folyamatot egy $72{ }^{\circ} \mathrm{C}$-on történő 60 másodpercig tartó lánchosszabbítás, majd 30 másodpercig tartó $12{ }^{\circ} \mathrm{C}$ on történő hűtés zárta le.

\subsubsection{Az ITS régióinak megsokszorozásához használt PCR reakció paraméterei}

A PCR reakciókat $22 \mu 1$ reakcióelegyben hajtottam végre, amely 0,4 $\mu 1$ Dreamtaq DNS polimerázt ( $2 \mathrm{U} / \mu \mathrm{l}), 2 \mu \mathrm{l}$ dezoxinukleozid-trifoszfát (dNTP) elegyet ( $2 \mathrm{mM}$ nukleozidonként), 1 $1 \mu \mathrm{l}$-t a $10 \mu \mathrm{M}$-os ITS1 és ITS4 primerekből (Metabion), $2 \mu$ l tízszeres koncentrációjú reakció puffert (Thermo Scientific) és $2 \mu 1$ DNS izolátumot tartalmazott. A DNS felszaporítását Bio-Rad $\mathrm{C} 1000^{\mathrm{TM}}$ Thermal Cycler típusú PCR készülékkel végeztem a következő paraméterekkel: $95{ }^{\circ} \mathrm{C}$ on 3 percig tartott a bevezető denaturálás, amit 27-szer ismétlődő $95{ }^{\circ} \mathrm{C}$-on történő, 30 másodpercig tartó denaturáció, 35 másodpercig tartó $59{ }^{\circ} \mathrm{C}$-on történő primer kötődési és $72{ }^{\circ} \mathrm{C}$ on történő 55 másodpercig tartó lánchosszabbítási szakaszból álló ciklus követett. A folyamatot egy $72{ }^{\circ} \mathrm{C}$-on történő 60 másodpercig tartó lánchosszabbítás, majd 30 másodpercig tartó $12{ }^{\circ} \mathrm{C}$ on történő hütés zárta le. 


\subsubsection{A Yarrowia csoport fajainak egymástól való elkülönítésének lehetőségei fiziológiai tesztek alapján}

Ahhoz, hogy megvizsgáljam a Yarrowia csoport fajainak egymástól fiziológiai tesztekkel való elkülönítésének lehetőségeit, először össze kellett gyüjtenem az egyes fajok fiziológiai tulajdonságairól a rendelkezésre álló adatokat. Ehhez felhasználtam a CBS adatbázist (http://www.cbs.knaw.nl/Collections/Biolomics.aspx?Table=CBS\%20strain\%20database), a jelenlegi legfrissebb monográfiát (Kurtzman et al. 2011) és a fajleírásokat. Az így összegyüjtött adatokat összegeztem, ahol ellentmondás volt, vagy nem állt rendelkezésre adat, azokat a fiziológiai teszteket magam is elvégeztem az említett monográfiában leírt módon (Kurtzman et al. 2011), majd táblázatot készítettem az eredményekről (5. táblázat).

Ezeket az adatokat használtam fel a határozókulcs elkészítéséhez.

A dolgozatban említett összes fiziológiai tesztet a monográfiában (Kurtzman et al. 2011) ismertetett módon végeztem el. 
5. táblázat. A Yarrowia csoport fajainak fiziológiai tulajdonságai

\begin{tabular}{|c|c|c|c|c|c|c|c|c|c|c|c|c|c|c|}
\hline Teszt & Fajok & 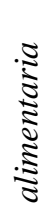 & $\stackrel{\overrightarrow{\tilde{\sigma}}}{\tilde{\sigma}}$ & 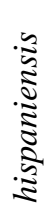 & 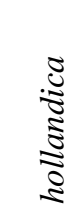 & 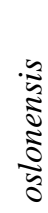 & 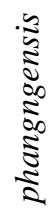 & $\frac{\vec{\Xi}}{\tilde{\Xi}}$ & 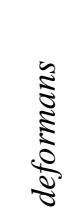 & 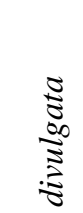 & 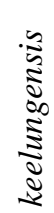 & 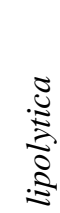 & 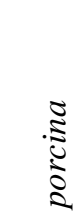 & 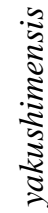 \\
\hline & & & & & & & & & & & & & & \\
\hline & D-UIUKOL & - & - & - & - & - & - & 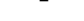 & - & & - & - & - & - \\
\hline & D-Galaktóz & - & - & - & - & - & - & - & - & - & - & - & - & - \\
\hline 幽 & Maltóz & - & - & - & - & - & - & - & - & - & - & - & - & - \\
\hline है & Szacharóz & - & - & - & - & - & - & - & - & - & - & - & - & - \\
\hline 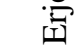 & Trehalóz & - & - & - & - & - & - & - & - & - & - & - & - & - \\
\hline & Laktóz & - & - & - & - & - & - & - & - & - & - & - & - & - \\
\hline & Raffinóz & - & - & - & - & - & - & - & - & - & - & - & - & - \\
\hline & D-Glükóz & + & + & + & + & + & + & + & + & + & + & + & + & + \\
\hline & D-Galaktóz & $\mathrm{v}$ & s/ws & - & + & - & - & s/ws/- & - & - & w & $\mathrm{v}$ & s/ws/- & - \\
\hline & L-Szorbóz & $\mathrm{v}$ & $\mathrm{v}$ & w & + & + & - & s/- & - & $\mathrm{s} / \mathrm{l} / \mathrm{v}$ & w & $\mathrm{v}$ & $\mathrm{v}$ & - \\
\hline & D-Glükózamin & - & - & - & - & - & - & - & - & - & - & - & $\mathrm{v}$ & - \\
\hline & N-Acetyl-D-Glükózamin & + & - & - & + & + & - & + & + & + & + & + & + & - \\
\hline & D-Ribóz & + & $-/ 1$ & - & - & $\mathrm{s}$ & $\mathrm{s}$ & + & $\mathrm{s}$ & + & w & $\mathrm{v}$ & + & - \\
\hline & D-Xilóz & - & - & - & - & $\mathrm{v}$ & - & - & - & - & - & - & - & - \\
\hline & L-Arabinóz & - & - & - & - & - & - & - & - & - & - & - & - & - \\
\hline & D-Arabinóz & - & - & - & - & - & - & - & - & - & - & - & - & - \\
\hline & L-Ramnóz & - & - & - & - & - & - & - & - & - & - & - & - & - \\
\hline & Szacharóz & - & - & - & - & - & - & - & - & - & - & - & - & - \\
\hline & Maltóz & - & - & - & - & - & - & - & - & - & - & - & - & - \\
\hline & $\alpha, \alpha$-Trehalóz & - & $\mathrm{v}$ & + & - & - & - & - & - & - & - & - & - & - \\
\hline$\overline{\bar{z}}$ & Me- $\alpha-D-$ glükozid & - & - & - & - & - & - & - & - & - & - & - & - & - \\
\hline. $\bar{\Xi}$ & Cellobióz & - & - & - & - & $\mathrm{s}$ & - & - & $-/ \mathrm{s}$ & - & - & w/- & w/ws/- & - \\
\hline N & Szalicin & - & $-/ w s$ & - & - & - & - & s/ws/- & $\mathrm{s} / \mathrm{l}$ & $\mathrm{s} / \mathrm{ws} / \mathrm{v}$ & + & w/- & $\mathrm{v}$ & - \\
\hline$\stackrel{\tilde{u}}{\mathfrak{w}}$ & Arbutin & - & $-/ w s$ & - & - & + & - & s/ws/- & $1 / \mathrm{s}$ & $\mathrm{s} / \mathrm{ws} / \mathrm{v}$ & - & - & $\mathrm{v}$ & - \\
\hline 贸 & Melibióz & - & - & - & - & - & - & - & - & - & - & - & - & - \\
\hline (1) & Laktóz & - & - & - & - & - & - & - & - & - & - & - & - & - \\
\hline N & Raffinóz & - & - & - & - & - & - & - & - & - & - & - & - & - \\
\hline & Melezitóz & - & - & - & - & - & - & - & - & - & - & - & - & - \\
\hline & Inulin & - & - & - & - & - & - & - & - & - & - & - & - & - \\
\hline & Keményítő & - & - & - & - & - & - & - & - & - & - & - & - & - \\
\hline & Glicerin & + & + & + & + & + & + & + & + & + & + & + & + & + \\
\hline & Eritrit & + & + & - & + & + & + & + & + & + & + & + & + & + \\
\hline & Ribit & - & $\mathrm{v}$ & - & - & + & - & $+/ \mathrm{s} / 1$ & - & $\mathrm{s} / \mathrm{ws} / \mathrm{v}$ & - & $\mathrm{v}$ & $\mathrm{s} / \mathrm{l} /-$ & - \\
\hline & Xilit & - & -/ws & - & - & - & - & $\mathrm{v}$ & - & - & - & - & s/ws/- & - \\
\hline & L-Arabinit & - & - & - & - & - & - & - & - & - & - & - & - & - \\
\hline & D-Szorbit & - & $+/ \mathrm{s}$ & + & - & + & 1 & $+/ s / w s$ & $\mathrm{~s} / \mathrm{l}$ & $+/ \mathrm{s} / 1$ & + & + & $\mathrm{v}$ & $\mathrm{w}$ \\
\hline & D-Mannit & + & $+/ 1$ & + & $\mathrm{w} /+$ & - & + & $+/ \mathrm{s}$ & + & $+/ \mathrm{s}$ & + & + & + & + \\
\hline & Galacit & - & - & - & - & - & - & - & - & - & - & - & - & - \\
\hline & myo-Inosit & - & - & - & - & - & - & - & - & - & - & - & - & - \\
\hline & D-Glükono-1,5-lakton & + & $+/ \mathrm{s} / 1$ & $\mathrm{~s}$ & + & + & + & + & + & + & + & + & $+/ \mathrm{s}$ & + \\
\hline & 2-Keto-D-glükonát & - & $\mathrm{s} / \mathrm{l} /-$ & - & - & - & - & - & - & - & - & - & - & - \\
\hline & D- Glükonát & + & $-/ 1 /+$ & - & + & + & - & $\mathrm{v}$ & + & + & + & $\mathrm{v}$ & $\mathrm{s} / 1 /-$ & + \\
\hline & D- Glükoronát & - & - & - & - & - & - & - & - & - & - & - & - & - \\
\hline
\end{tabular}


5. táblázat. A Yarrowia csoport fajainak fiziológiai tulajdonságai (folytatás)

\begin{tabular}{|c|c|c|c|c|c|c|c|c|c|c|c|c|c|c|}
\hline Teszte & Fajok & 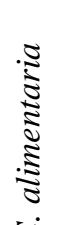 & $\underset{\infty}{\stackrel{\tilde{\Xi}}{0}}$ & 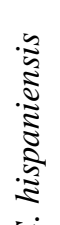 & 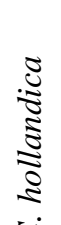 & 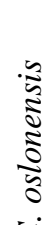 & 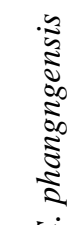 & 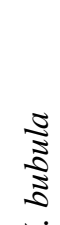 & 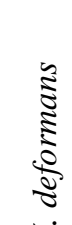 & 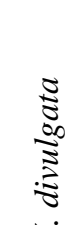 & 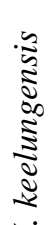 & 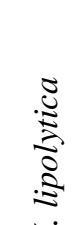 & 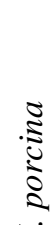 & 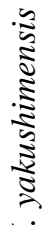 \\
\hline & D-Galakturonát & - & $-/ \mathrm{s} /+$ & - & - & - & - & - & - & - & - & - & - & $\pi$ \\
\hline & DL-Laktát & + & + & + & + & + & + & + & $\mathrm{w} /+$ & + & + & + & + & + \\
\hline 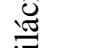 & Szukcinát & + & + & + & + & + & + & + & + & + & $\mathrm{w}$ & + & + & + \\
\hline$\Xi$ & Citrát & + & + & - & + & + & $\mathrm{s}$ & + & + & + & + & + & + & + \\
\hline $\begin{array}{l}N \\
D \\
D\end{array}$ & Szacharát & - & - & - & - & - & - & - & - & - & - & - & - & - \\
\hline $\begin{array}{l}\tilde{1} \\
\dot{y}\end{array}$ & Metanol & - & - & - & - & - & - & - & - & - & - & - & - & - \\
\hline $\mathscr{0}$ & Etanol & + & + & $\mathrm{v}$ & + & + & + & + & + & + & + & + & + & + \\
\hline$\widetilde{\tilde{U}}$ & Propán 1,2 diol & - & $-/ \mathrm{s} /+$ & + & + & $\mathrm{s}$ & $\mathrm{w}$ & $\mathrm{v}$ & $\mathrm{v}$ & $+/ \mathrm{s} / \mathrm{ws}$ & w & - & $\mathrm{v}$ & - \\
\hline N & Bután 2,3 diol & - & $-/ \mathrm{s} / \mathrm{ws}$ & - & - & - & - & s/- & - & $\mathrm{s} / \mathrm{ws} / \mathrm{v}$ & - & - & - & + \\
\hline & Hexadekán & + & + & + & + & + & + & + & + & + & + & + & + & + \\
\hline & Nitrát & - & - & - & - & - & - & - & - & - & - & - & - & - \\
\hline & Nitrit & - & - & - & - & - & - & - & - & - & - & - & - & - \\
\hline$\stackrel{1}{*} 0$ & Etilamin & + & + & + & - & + & + & + & + & + & + & + & + & + \\
\hline ప : : & L-Lizin & + & + & + & + & + & + & + & + & + & + & + & + & + \\
\hline$\overline{\mathbb{D}} \bar{\Xi}$ & Kadaverin & + & + & + & + & + & + & + & + & + & + & + & + & + \\
\hline రD & Kreatin & - & - & - & - & - & - & - & - & - & - & - & - & - \\
\hline 击 & Kreatinin & - & - & - & - & - & - & - & - & - & - & - & - & - \\
\hline & Glükózamin & - & - & - & - & - & - & - & - & - & - & - & - & - \\
\hline & Imidazol & w & - & - & - & - & - & - & - & - & - & - & - & - \\
\hline & $25^{\circ} \mathrm{C}$ & + & + & + & + & + & + & + & + & + & + & + & + & + \\
\hline & $30^{\circ} \mathrm{C}$ & - & + & + & + & + & + & - & + & + & + & + & + & - \\
\hline 䆑: : & $35^{\circ} \mathrm{C}$ & - & - & $\mathrm{v}$ & - & - & + & - & - & - & + & $\mathrm{v}$ & $\mathrm{v}$ & - \\
\hline สู & $37^{\circ} \mathrm{C}$ & - & - & $\mathrm{v}$ & - & - & + & - & - & - & - & $\mathrm{v}$ & - & - \\
\hline 氖 & $40^{\circ} \mathrm{C}$ & - & - & - & - & - & - & - & - & - & - & - & - & - \\
\hline $\bar{D}: \bar{\Xi}$ & $0.01 \%$ Cikloheximid & + & + & + & + & + & + & + & + & + & + & + & + & + \\
\hline 完: & $0.1 \%$ Cikloheximid & + & + & + & + & + & + & + & + & + & + & + & + & + \\
\hline N $: 0$ & $1 \%$ Ecetsav & - & - & - & - & - & - & - & - & - & - & - & - & - \\
\hline & 50\% D-Glükóz & - & - & - & - & - & - & - & - & - & - & - & - & - \\
\hline Kemé1 & nyítőképzés & - & - & - & - & - & - & - & - & - & - & - & - & - \\
\hline Savter & melés & + & $+/ \mathrm{w}$ & - & - & - & - & - & $\mathrm{v}$ & - & + & - & $\mathrm{v}$ & - \\
\hline Urea $h$ & iidrolízis & - & - & - & - & - & - & - & - & - & - & - & - & - \\
\hline Színre & akció DBB -vel & - & - & - & - & - & - & - & - & - & - & - & - & - \\
\hline $\begin{array}{l}\text { Szapo } \\
\text { tápköz }\end{array}$ & $\begin{array}{l}\text { rodás vitaminmentes } \\
\text { egben }\end{array}$ & - & + & - & - & - & - & - & - & - & - & - & - & - \\
\hline $\begin{array}{l}\text { Szapor } \\
\text { glükóz } \\
\text { base tá }\end{array}$ & $\begin{array}{l}\text { rodás } 10 \% \mathrm{NaCl} \text { és } 5 \% \\
\text { atartalmú yeast nitrogen } \\
\text { ápközegben }\end{array}$ & $\mathrm{s}$ & + & - & + & + & $1 /+$ & + & + & + & + & $\mathrm{s} / \mathrm{l} /+$ & + & - \\
\hline $\begin{array}{l}\text { Szapor } \\
\text { glükóz } \\
\text { base tá }\end{array}$ & $\begin{array}{l}\text { rodás } 16 \% \mathrm{NaCl} \text { és } 5 \% \\
\text { atartalmú yeast nitrogen } \\
\text { ápközegben }\end{array}$ & - & - & - & - & - & - & - & - & - & - & - & - & - \\
\hline
\end{tabular}

w: gyenge szaporodás; s: lassú szaporodás; ws: gyenge és lassú szaporodás; l: késleltetett szaporodás; v: változó 


\subsubsection{A Yarrowia csoport tagjainak az élelmiszerek romlásához potenciálisan hozzájáruló tulajdonságainak tesztelése}

A rendelkezésemre álló összes Yarrowia csoportba tartozó törzs szakirodalom által említett romlást okozó képességével összefüggő tulajdonságait vizsgáltam, vagyis pigmentképző-, fehérjebontó- és zsírbontó-képességét. Az általam izolált törzseken kívül a 2. táblázatban felsorolt referencia törzseket, köztük a típustörzseket is, összesen 273 törzset vizsgáltam. A vizsgálatokhoz 48 órás GPY ferdeagar tenyészeteket használtam.

\subsubsection{Pigmentképzés tesztelése}

A pigmenttermelő-képességet tirozintartalmú táptalajon vizsgáltam (Carreira és Loureiro 1998). A 48 órás tenyészetekből az agarlemez felszínére szélesztettem, amit $25^{\circ} \mathrm{C}$-on inkubáltam. Az értékelést 24 óra múlva végeztem, a kinőtt telep körül megjelenő vörösesbarna elszíneződés jelezte a törzs pigmentképző-képességét.

\subsubsection{Lipolitikus aktivitás tesztelése}

A lipolitikus aktivitást 5\% olívaolajjal kiegészített Gorodkowa agarlemezre való szélesztéssel teszteltem. $25{ }^{\circ} \mathrm{C}$-on történő, 10 napos inkubációt követően a lemezeket 1 percre elárasztottam telített réz-szulfát oldattal. A pozitív eredményt a telepek kék elszíneződése jelezte (Marquina et al. 1992).

\subsubsection{Proteolitikus aktivitás tesztelése}

A törzsek fehérjebontó képességét zselatin-hidrolízis tesztelése által mértem fel. A zselatinttartalmú táptalajt tartalmazó kémcsöveket $0,1 \mathrm{ml}, 2+$,'-es mikroba-szuszpenzióval való beoltás után $25^{\circ} \mathrm{C}$-on inkubáltam 3 hétig. A leolvasást hetente végeztem, leolvasás elött 1 órára hütőszekrénybe helyeztem a kémcsöveket. A proteolitikus aktivitást az elfolyósodott, hűtőszekrény hőmérsékletén is folyékony zselatin jelezte (Kurtzman et al. 2011). 


\subsubsection{Spóráztatás}

Az aszkospóraképzés teszteléséhez egy fajba tartozó törzsek 48 órás tenyészeteit oltókaccsal GPY lemezen alaposan összekevertem (egyszerre legfeljebb öt törzset), majd a keverékeket különböző ferdeagarokra oltottam. Az alábbi ferdeagarokat használtam:

- acetát agar,

- kukoricaliszt agar (CMA),

- Spezieller Nährstoffarmer Agar" (SNA),

- burgonya-dextróz agar (PDA),

- $2 \%$ maláta kivonat agar (MEA),

- glükóz-pepton-élesztőkivonat agar (GPY),

- módosított glükóz-pepton-élesztőkivonat agar(GPYA),

- élesztökivonat-malátakivonat agar (YM),

- V8 agar,

- nitrát agar,

- yeast-carbon base (YCB) agar,

- yeast-carbon base agar 0,01\% ammónium-szulfáttal kiegészítve (YCBAS),

- restricted growth $(\mathrm{RG})$ agar és

- élesztőkivonat-szacharóz (YES) agar.

Az említett táptalajok Kurtzman és munkatársai (2011) leírása alapján készültek, vagy összetételük megtalálható az M1 mellékletben. A YES agart penészgombák másodlagos anyagcseretermékeinek vizsgálatához használják (Samson et al. 2004), sporulációs vizsgálatokhoz azért használtam, mert a MIMNG korábbi tapasztalatai alapján lehetővé teszi Yarrowia (Candida) deformans törzsek keverékének aszkospóra képzését.

A tenyészeteket 15 és $25^{\circ} \mathrm{C}$-on inkubáltam három hétig, majd Kurtzman és munkatársai (2011) ajánlásának megfelelően 7 és 21 nap után preparátumokat készítettem és fénymikroszkóppal kerestem aszkuszokat és aszkospórákat. Abban az esetben, ha aszkospórákat találtam, az adott keverékben jelen lévő tenyészetek sporulációját ugyanazon körülmények között, törzsenként is és páronként is teszteltem az összes lehetséges kombinációban. 


\section{EREDMÉNYEK ÉS ÉRTÉKELÉSÜK}

\subsection{Az izolálási módszer hatékonysága, az izolált élesztőgombatörzsek}

Az újonnan kidolgozott kis pH-jú, szénforrásként hexadekánt tartalmazó táplevesben történő dúsításos módszert használva összesen 826 élesztőgomba törzset izoláltam 133 különböző élelmiszermintából.

A 6. táblázatban foglaltam össze, hogy a különböző élelmiszermintákból hány élesztőgombatörzset izoláltam ezzel az új módszerrel, a két különböző dúsító táplevessel.

6. táblázat. A felhasznált élelmiszermintákból az új izolálási módszerrel izolált élesztőgombák száma

\section{Izolátumok forrása}

\section{Izolátumok száma}

\section{1. dúsító táplevessel \\ (118 élelmiszerminta) \\ 2. dúsító táplevessel \\ (15 élelmiszerminta)}

Darált sertéshús

Darált marhahús

Darált marha- és sertéshús keveréke

10

Pulyka húspép

7

Pulyka darált hús

5

Pulyka mellfilé

Gyorsfagyasztott pulykahús

Oldalas

$$
1
$$

Nyers tej

Sajt

Túró

143

86

Összesen

729

97 
Korábban nem állt rendelkezésre olyan izolálási módszer, mellyel hatékonyan lehetne Yarrowia csoportba tartozó élesztőgomba törzseket izolálni.

A háromlépéses dúsítás hatékonynak bizonyult mindkét dúsító tápleves esetében. Az inokulált dúsító folyadékban minden egyes dúsító lépés után egyre kisebb arányban voltak jelen baktériumok, a dúsító folyamat végére a legtöbb esetben azok már egyáltalán nem voltak megtalálhatók a dúsító levesben. A harmadik dúsító lépés után a dúsított szuszpenzióból készített hattagú hígítási sor utolsó három tagjából történt szélesztést követően, a hét napos inkubációs idő leteltével az RBC lemezekről az elvárásoknak megfelelően csak igen kevés esetben nőttek ki baktérium- vagy penészgomba telepek, az izolálható mikrobák többsége élesztőgomba volt, melyek jelentős hányadáról a későbbiekben bebizonyosodott, hogy a Yarrowia csoport tagjai.

A dúsító táplevessel szemben alapvető elvárás volt, hogy annak pH-ja a baktériumok szaporodásának visszaszorítása érdekében azok szaporodási optimumánál jóval alacsonyabb (de a Yarrowia csoport tagjainak szaporodását hátrányosan nem befolyásoló), 3,4-3,6-os értékü legyen, ezért elkészítéséhez pufferoldat alkalmazására volt szükség. A módszer szelektivitásának elméleti alapja az alacsony pH érték mellett az volt, hogy specifikus szénforrásként hexadekánt tartalmaz, ami a nem Yarrowia csoportba tartozó élesztőgombák zömének szaporodását nem teszi lehetővé, mivel a csoport tagjain kívül a legtöbb élesztőgombafaj nem képes a hexadekán asszimilációjára, vagy legalábbis nem ismert ez a képessége.

A dúsító tápleves elkészítéséhez először citromsav és dinátrium-hidrogén-foszfát felhasználásával készített McIlvaine puffer oldatot használtam. Mivel ebben a táplevesben annak citromsavtartalma miatt számos hexadekánt nem asszimiláló törzs is elszaporodott, a módszer hatékonyságának növelése érdekében a McIlvaine puffer helyett egy másik, foszfát $\left(\mathrm{KH}_{2} \mathrm{PO}_{4}\right.$ foszforsav) puffer oldatot próbáltam ki, amely kálium-dihidrogén-foszfátot és foszforsavat tartalmazott. Ez utóbbi dúsító leves így a hexadekánt egyedüli szénforrásként tartalmazza. Utóbbi tápleves teszteléséhez 4 darált sertéshús- és 11 túró mintát használtam fel, de ezek feldolgozásához külön-külön mindkét dúsító levest felhasználtam, hogy azok hatékonyságát össze tudjam hasonlítani.

\subsubsection{A McIlvaine puffer oldatot tartalmazó dúsító tápleves felhasználásával izolált törzsek vizsgálata}

\subsubsection{Hexadekán-asszimiláció}

Az élesztőgomba törzsek izolálása után, minden további vizsgálat előtt szükséges volt ellenőrizni, hogy azok valóban képesek-e asszimilálni a hexadekánt. 
A McIlvain puffer oldattal készült dúsító felhasználásával 620 élesztőgombát izoláltam, közülük 256 hexadekán-pozitív (41\%). Nyers húsból izolált 294 élesztőgomba törzs közül 159 (54\%), tejtermékekből izolált 326 élesztőgomba törzs közül 97 képes hasznosítani a hexadekánt (30\%). A különböző tejtermékekből izolált törzsek hexadekán-asszimilációját külön-külön értékelve eltérés mutatkozik. Túróból izolált 51 törzs közül 19 (37\%), tejböl izolált 218 törzs közül 43 (20\%), sajtból izolált 57 törzs közül pedig 35 törzs hexadekán-pozitív (61\%).

Az alábbi diagramokon (3-5. ábra) mutatom be, hogyan oszlanak meg az izolált törzsek hexadekán-asszimiláló képességük alapján az izolálási forrásul szolgáló élelmiszerekben.

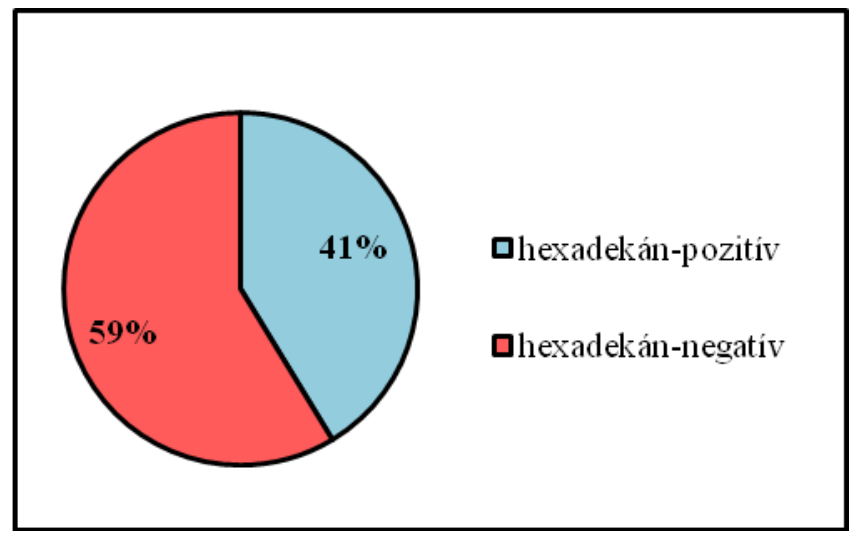

3. ábra. McIlvaine puffert tartalmazó dúsító táplevessel izolált élesztőgomba törzsek megoszlása hexadekán-asszimiláló képességük szerint (620 törzs)

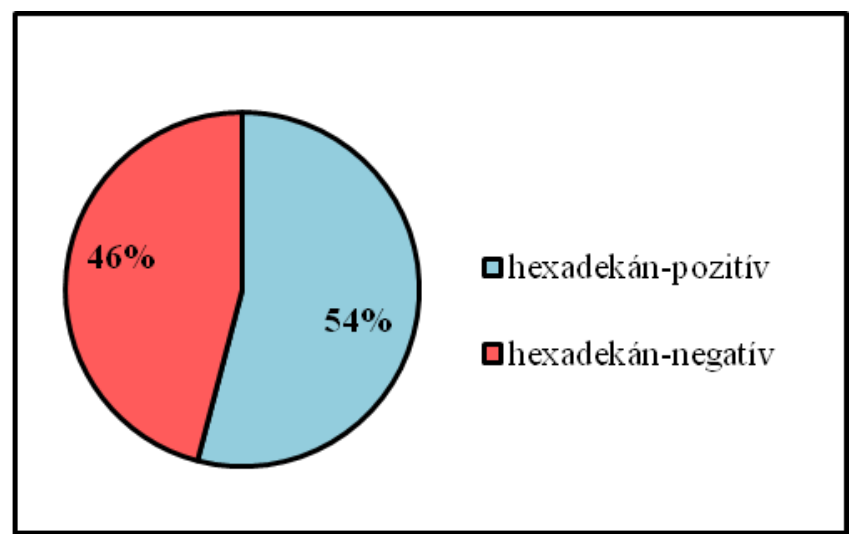

4. ábra. McIlvaine puffert tartalmazó dúsító táplevessel nyers húsból izolált élesztőgomba törzsek megoszlása hexadekán-asszimiláló képességük szerint (294 törzs) 


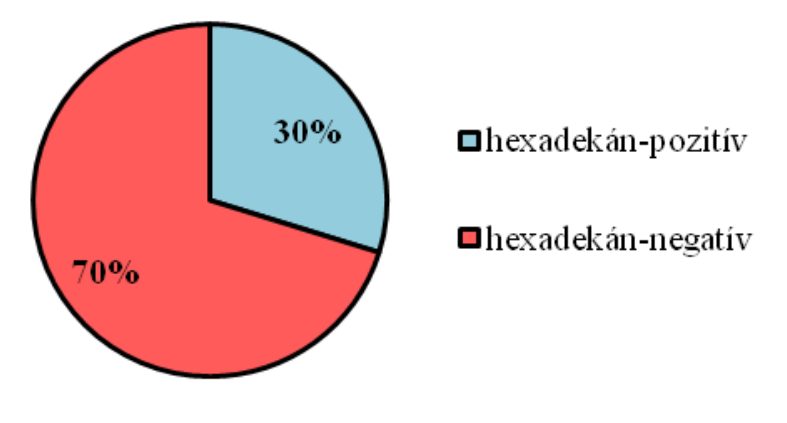

5. ábra. McIlvaine puffert tartalmazó tartalmazó dúsító táplevessel nyers tejből és tejtermékekből izolált összes élesztőgomba törzs megoszlása hexadekán-asszimiláló képességük szerint (326 törzs)

Az említett dúsító tápleves felhasználásával sajtból és nyers húsból lehetett leghatékonyabban hexadekán-asszimiláló élesztőgomba törzseket izolálni.

\subsubsection{A Yarrowia csoportba tartozó törzsek elkülönítése fiziológiai tesztekkel}

A fent említett 256 hexadekán-asszimiláló törzs közül a glükóz erjesztés és nitrát teszt, valamint API ID $32 \mathrm{C}$ tesztekkel vizsgált további fiziológiai jellemzőik alapján kerültek kiválasztásra a Yarrowia csoport tagjai. Százhatvanhárom törzs bizonyult a Yarrowia csoport tagjának, glükóz erjesztés, nitrát-asszimiláció- és a hexadekánon kívül további 30 szénforrásasszimilációs teszt alapján, azokat a 4. táblázat adataival összevetve. A McIlvaine puffert tartalmazó dúsító tápleves felhasználásával izolált hexadekán-asszimiláló törzseknek nagyobb hányada (64\%) a Yarrowia csoportba tartozik (6. ábra).

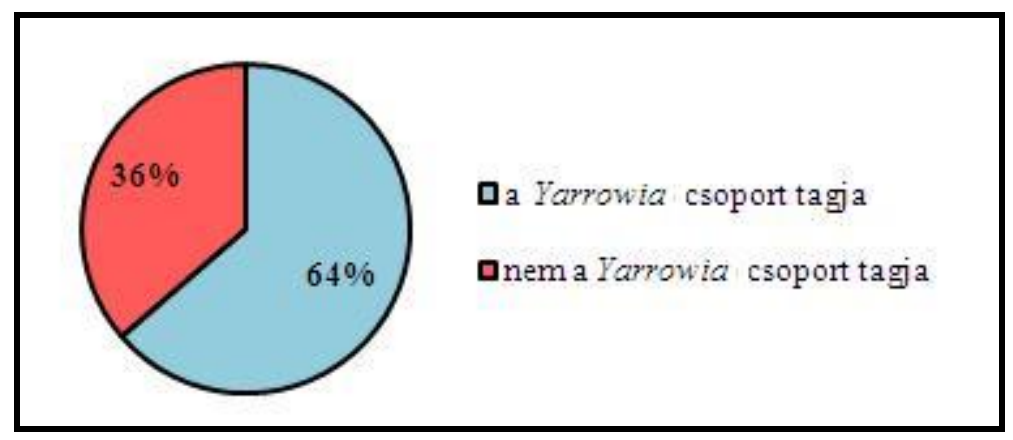

6. ábra. McIlvaine puffert tartalmazó dúsító táplevessel izolált összes hexadekán-pozitív élesztőgomba törzs megoszlása aszerint, hogy a Yarrowia csoportba tartozik-e (256 törzs) 
A 7-8. ábrákon bemutatott értékeket az egyes élelmiszerfajtákból izolált hexadekán-asszimiláló élesztőgomba törzseket figyelembe véve kaptam meg.

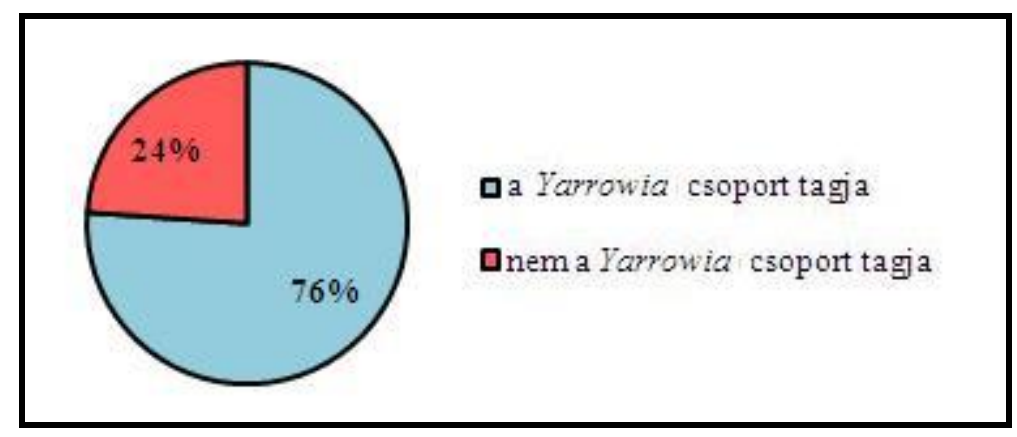

7. ábra. Nyers húsból McIlvaine puffert tartalmazó tartalmazó dúsító táplevessel izolált hexadekán-asszimiláló élesztőgomba törzsek megoszlása aszerint, hogy a Yarrowia csoportba tartoznak-e (159 törzs)

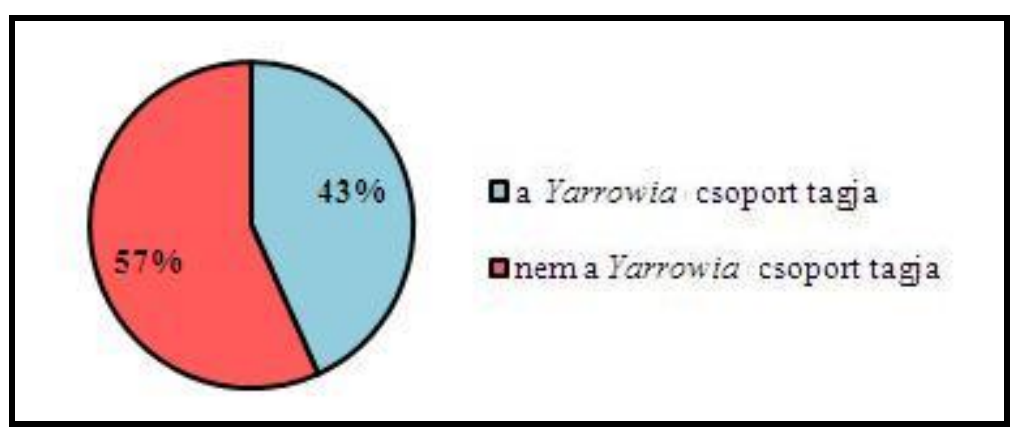

8. ábra. Nyers tejből és tejtermékekből McIlvaine puffert tartalmazó dúsító táplevessel izolált hexadekán- asszimiláló élesztőgomba törzsek megoszlása aszerint, hogy a Yarrowia csoportba tartoznak-e (97 törzs)

Százötvenkilenc nyers húsból izolált hexadekán-asszimiláló élesztőgomba törzs közül 76\% (121 törzs) a Yarrowia csoport tagja, nyers tejből és tejtermékekből izolált 97 hexadekánasszimiláló élesztőgomba törzs közül pedig 43\% (42 törzs). Nyers tejböl izolált 43 hexadekánasszimiláló élesztőgomba törzs közül csak 13 tartozik a Yarrowia csoportba, lejárt fogyaszthatósági idejű túró mintákból izolált 19 hexadekán-asszimiláló élesztőgomba törzs közül 18, sajt esetében 35 törzs közül pedig 11 törzs a Yarrowia csoport tagja.

A fentiek alapján a McIlvaine puffert tartalmazó dúsító táplevessel lejárt fogyaszthatósági idejű túróból és nyers húsból lehetett leghatékonyabban Yarrowia csoportba tartozó élesztőgomba törzseket izolálni.

Szembetűnő, hogy míg a nyers tejből izolált hexadekán-asszimiláló élesztőgomba törzsek 30\%-a tartozott a Yarrowia csoportba, addig ez az arány a lejárt fogyaszthatósági idejü túró mintákból izolált élesztőgomba törzsek esetén elérte a 95\%-ot. 


\subsubsection{A foszfát puffer oldatot tartalmazó dúsító tápleves felhasználásával izolált törzsek vizsgálata}

\subsubsection{Hexadekán-asszimiláció}

A fosztfát puffer oldatot tartalmazó dúsító leves felhaszálásával 4 darált sertéshúsmintából izolált 11 törzs közül 8 bizonyult hexadekán-pozitívnak (73\%), a túróból izolált 86 törzs közül pedig 69 (80\%).

\subsubsection{A Yarrowia csoportba tartozó törzsek elkülönítése fiziológiai tesztekkel}

A fosztfát puffer oldatot tartalmazó dúsító tápleves felhaszálásával izolált 77 hexadekánasszimiláló törzs közül a glükózerjesztés és nitrát teszt, valamint API ID 32 C tesztekkel vizsgált további fiziológiai jellemzőik alapján kerültek kiválasztásra a Yarrowia csoport tagjai. Harmincnégy törzs bizonyult a Yarrowia csoport tagjának, glükóz erjesztés, nitrát-asszimilációés a hexadekánon kívül további 30 szénforrás-asszimilációs teszt alapján, azokat a 4. táblázat adataival összevetve. A foszfát puffert tartalmazó dúsító felhasználásával izolált hexadekánasszimiláló törzsek 44\%-a tartozik a Yarrowia csoportba.

\subsubsection{A dúsító táplevesek hatékonyságának összehasonlítása}

Ahhoz, hogy a két különböző puffer oldattal készített dúsító tápleves hatékonyságát összehasonlítsam, csak azokból a mintákból izolált törzseket vettem figyelembe, amelyekhez párhuzamosan mindkét dúsító táplevest felhasználtam (4 hús- és 11 túróminta, utóbbiak kétszer lettek feldolgozva, először frissen, másodszor pedig a minőség-megőrzési idő lejárta után).

Az említett 15 mintából 206 élesztőgombatörzset izoláltam, közülük 137 hexadekán-pozitív (67\%), közülük 56 törzs a csoport tagja (hexadekán-pozitívak 41\%-a, 11 mintából izolált összes törzs 27\%-a). Ezek megoszlását a 9. ábra mutatja.

Kétszázhat törzs közül 109-et izoláltam a McIlvaine puffert tartalmazó Yarrowia-dúsító táplevessel, közülük 60 hexadekán-pozitív (55\%), ebből 23 a csoport tagja (38\%). A módosított (hexadekánon kívül más szénforrást nem tartalmazó) Yarrowia-dúsító tápleves felhasználásával 97 élesztőgombatörzset izoláltam, ahogy már említettem, közülük 77 volt képes elszaporodni a hexadekán-asszimiláció tesztelésére szolgáló táplevesben (79\%), ami egyedüli szénforrásként hexadekánt tartalmazott, közülük 34 törzs a csoport tagja (44\%). 


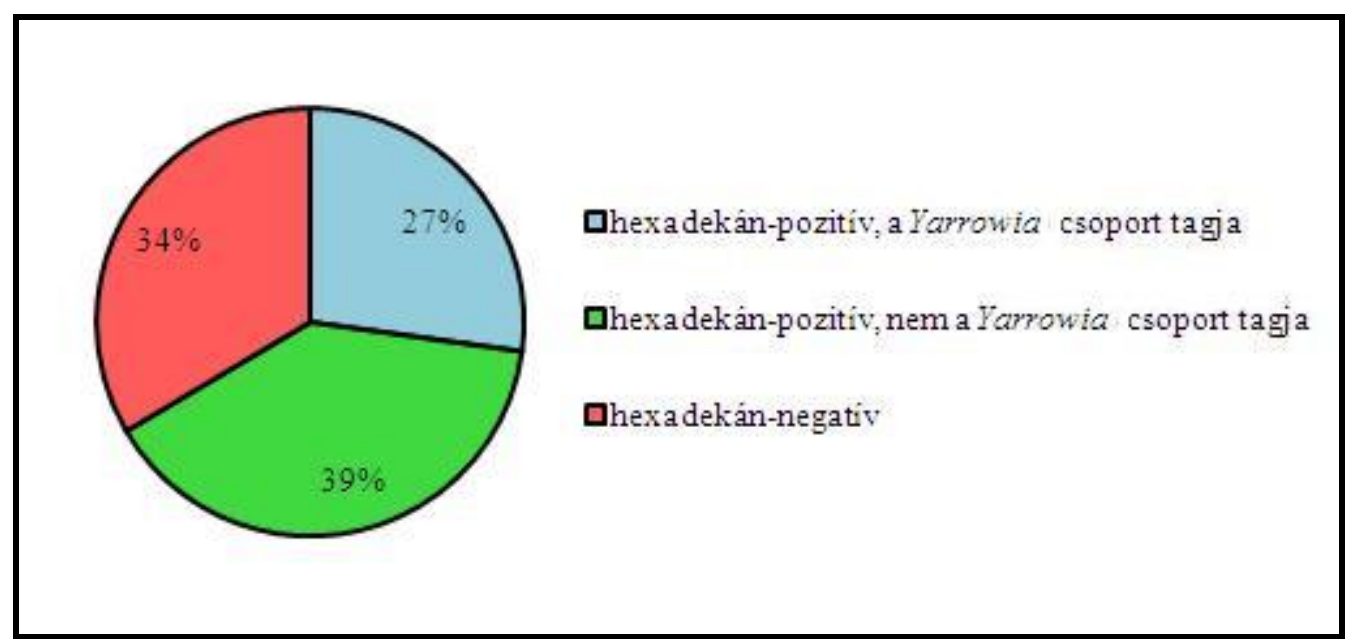

9. ábra. A Yarrowia-dúsító táplevesek összehasonlításához felhasznált mintákból izolált 206 törzs megoszlása

A négy húsmintából izolált 28 törzs közül 17-et az első- (mikrobák által szénforrásként felhasználható citromsavat is tartalmazó), 11-et a módosított dúsítóval izoláltam. Előbbiek közül 13 törzs hexadekán-pozitív (76\%), ebböl 8 törzs a csoport tagja (hexadekán-pozitívak 62\%-a, a négy húsmintából izolált összes törzs 47\%-a); a módosított dúsítóval izoláltak közül 8 törzs hexadekán-pozitív (73\%), ebböl 6 törzs a csoport tagja (hexadekán-pozitívak 75\%-a, a négy húsmintából izolált összes törzs 55\%-a) (7. táblázat).

7. táblázat. A Yarrowia-dúsító táplevesek összehasonlításához felhasznált nyers húsmintákból McIlvaine puffert (1. dúsító) és foszfát puffert (2. dúsító) tartalmazó tápleves felhasználásával izolált törzsek megoszlása

1. dúsító

2. dúsító

Nyers húsból izolált törzsek

17 törzs

11 törzs

Nyers húsból izolált hexadekán-pozitív törzsek

13 törzs $(76 \%)$

8 törzs (73\%)

Nyers húsból izolált hexadekán-pozitív törzsek közül a Yarrowia csoport tagja

8 törzs $(62 \%) \quad 6$ törzs $(75 \%)$

Nyers húsból izolált törzsek közül a

Yarrowia csoport tagja

8 törzs $(47 \%) \quad 6$ törzs $(55 \%)$ 
A 10. és 11. ábrán mutatom be, hogyan oszlanak meg a Yarrowia-dúsító táplevesek összehasonlításához felhasznált nyers húsmintákból az első és a módosított dúsító levessel izolált törzsek.

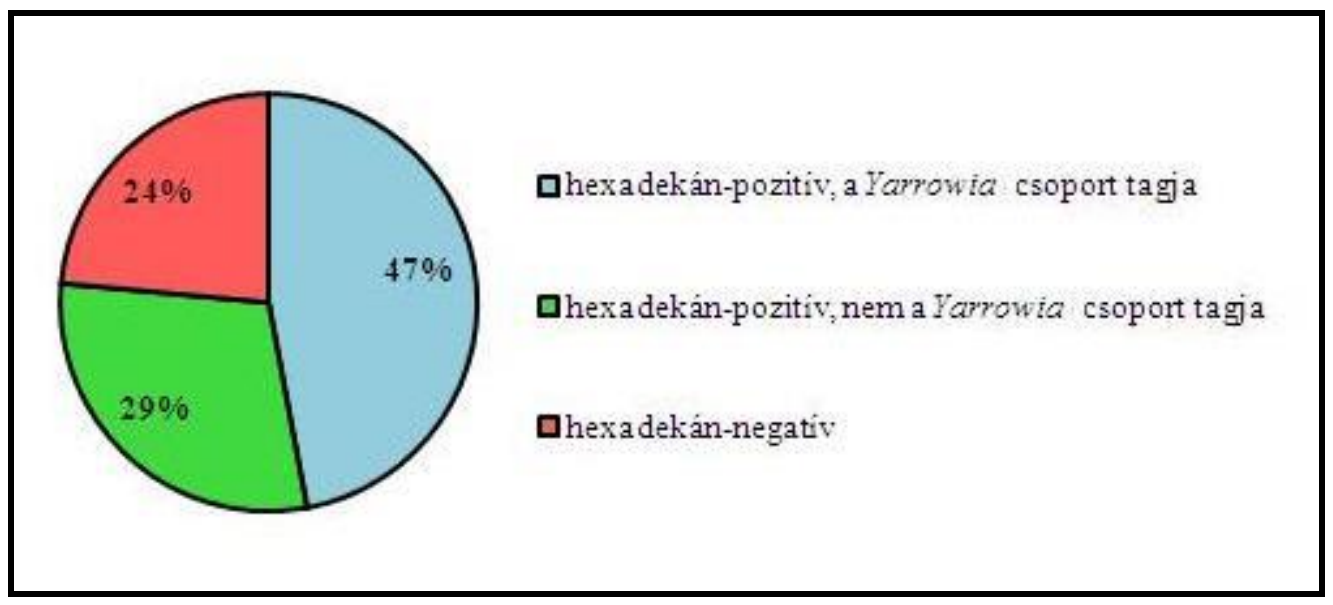

10. ábra. A Yarrowia-dúsító táplevesek összehasonlításához felhasznált nyers húsmintákból McIlvaine puffert tartalmazó dúsító táplevessel izolált 17 törzs megoszlása

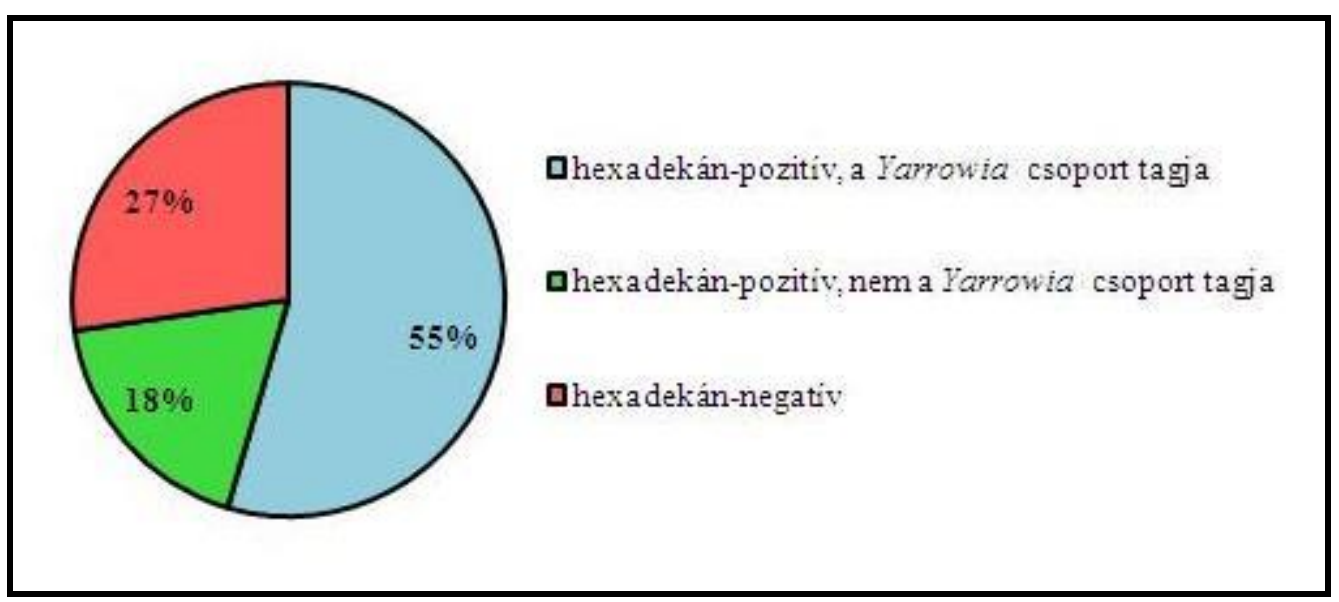

11. ábra. A Yarrowia-dúsító táplevesek összehasonlításához felhasznált nyers húsmintákból foszfát puffert tartalmazó dúsító táplevessel izolált 11 törzs megoszlása

Bár a várttal ellentétben a foszfát puffert tartalmazó dúsító táplevessel kissé kevesebb hexadekán-pozitív törzset lehetett izolálni a vizsgált 4 nyers húsmintából, arányait tekintve hatékonyabb volt ez a módszer a Yarrowia csoport tagjainak izolálása szempontjából, akár a hexadekán-pozitív törzsekhez, akár az adott dúsítóval izolált összes törzshöz viszonyítjuk arányukat. 
A 11 túrómintából izolált 178 törzs közül 92-t a McIlvaine puffert, 86-ot a foszfát puffert tartalmazó dúsítóval izoláltam. Előbbiek közül 47 törzs hexadekán pozitív (51\%), ebből 15 törzs a csoport tagja (hexadekán-pozitívak 32\%-a, összes 16\%-a); utóbbiak közül 69 törzs hexadekánpozitív (80\%), ebböl 28 törzs a csoport tagja (a hexadekán-pozitív törzsek 41\%-a, az összes törzs 33\%-a) (8. táblázat).

8. táblázat. A Yarrowia-dúsító táplevesek összehasonlításához felhasznált túrómintákból McIlvaine puffert (1. dúsító) és foszfát puffert (2. dúsító) tartalmazó tápleves felhasználásával izolált törzsek megoszlása

1. dúsító

2. dúsító

Túróból izolált törzsek

Túróból izolált hexadekán-pozitív törzsek

Túróból izolált hexadekán-pozitív törzsek közül a Yarrowia csoport tagja

Túróból izolált törzsek közül a Yarrowia csoport tagja

\section{2 törzs}

47 törzs (51\%)

15 törzs $(32 \%)$

15 törzs $(16 \%)$

\section{6 törzs}

69 törzs $(80 \%)$

28 törzs (41\%)

28 törzs (33\%)

A 12. és 13. ábrákon mutatom be, hogyan oszlanak meg a túrómintákból izolált törzsek.

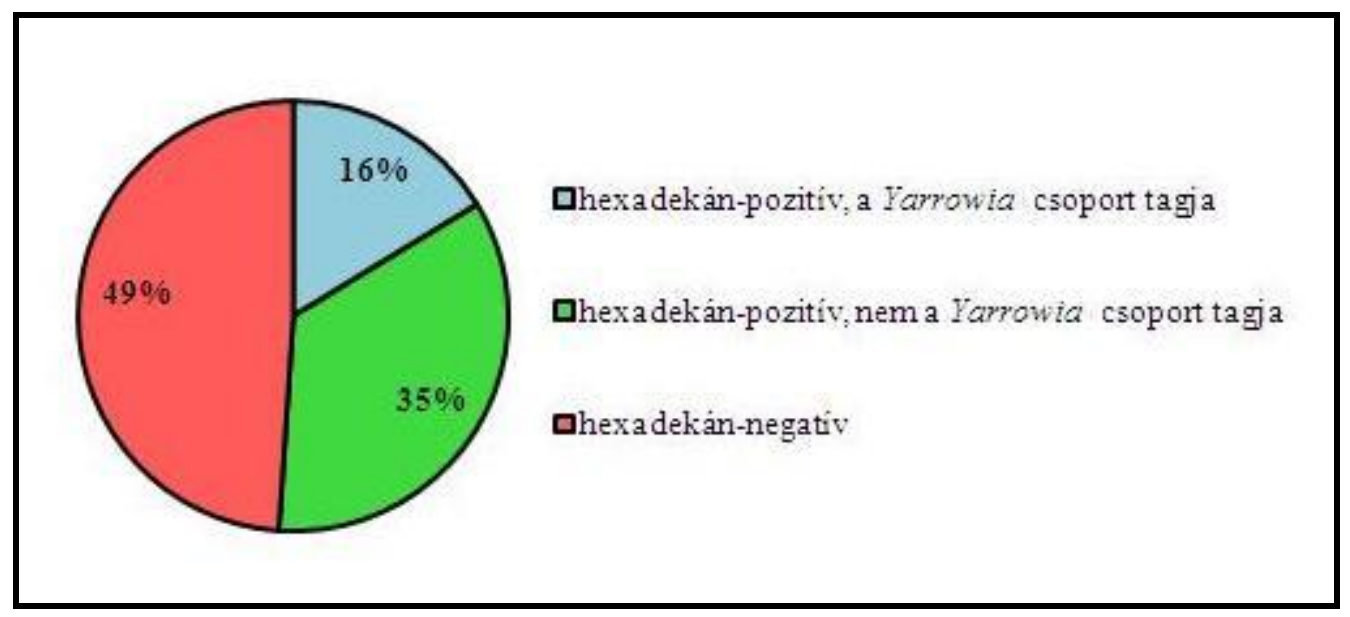

12. ábra. A Yarrowia-dúsító táplevesek összehasonlításához felhasznált túrómintákból McIlvaine puffert tartalmazó dúsító táplevessel izolált 92 élesztőgomba törzs megoszlása 


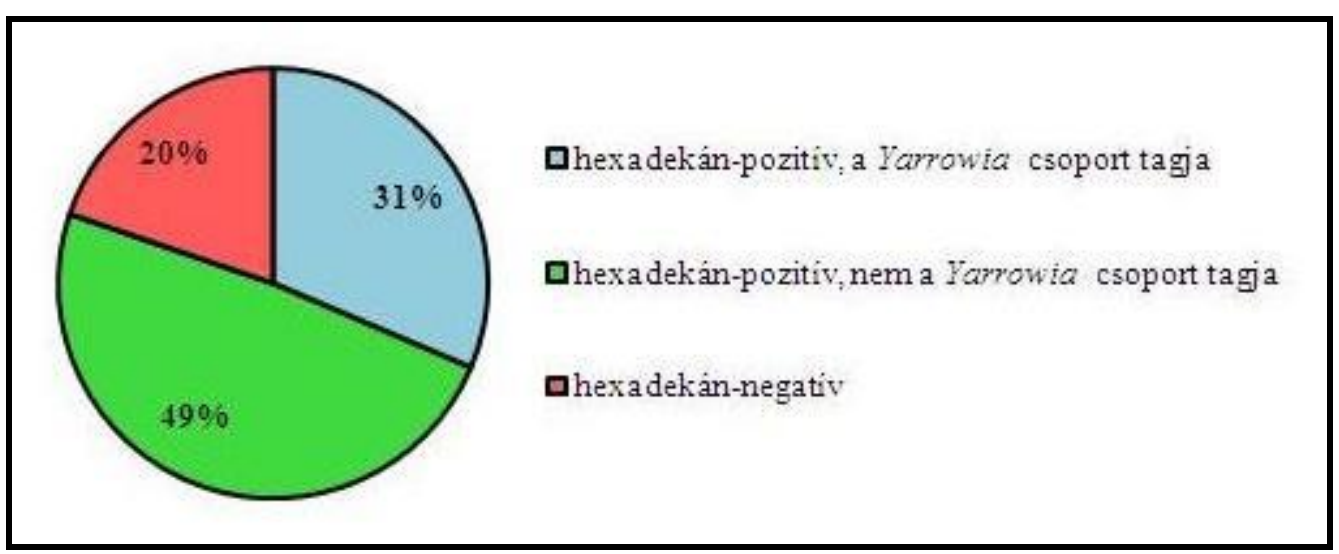

13. ábra. A Yarrowia-dúsító táplevesek összehasonlításához felhasznált túrómintákból foszfát puffert tartalmazó dúsító táplevessel izolált 86 élesztőgomba törzs megoszlása

A kapott eredmények alapján a túrómintákból izolált törzsek esetében már nem csak a Yarrowia csoport tagjainak aránya nagyobb a módosított dúsítóval, hanem az eredeti célnak megfelelően a hexadekán-pozitív törzsek száma is jóval nagyobb.

A kétfajta dúsításos módszerrel összesen 219 Yarrowia csoportba tartozó törzset izoláltam.

Mivel mindkét izolálási módszerrel a Yarrowia csoport tagjain kívül más törzsek is izolálásra kerültek, nem állítható, hogy bármelyik módszer teljes mértékben szelektív, de mindkettő hatékonyan alkalmazható a Yarrowia csoport tagjainak nagy számban történő izolálásához.

\subsection{A Yarrowia csoportba tartozó törzsek megoszlása}

A két dúsító tápleves összehasonlíthatósága érdekében eddig külön részleteztem azoknak a törzseknek a megoszlását, melyeket azokból a mintákból izoláltam, amiknél csak az első dúsítót használtam fel, és azokat, melyeknél mindkét dúsítót kipróbáltam. Az alábbi táblázatban (9. táblázat) az egyes élelmiszerekből izolált összes törzs (első és módosított dúsító felhasználásával izolált törzsek is szerepelnek) számát tüntettem fel, a 14.-19. ábrákon pedig az egyes élelmiszertípusokból izolált összes élesztőgomba törzs megoszlását mutatom be, tekintet nélkül arra, hogy melyik dúsító tápleves felhasználásával izoláltam őket. 
9. táblázat. Egyes élelmiszercsoportokból izolált törzsek száma

HÚS

\begin{tabular}{lccccc} 
& & TÚRÓ & TEJ & SAJT & összesen \\
\hline 1. dúsító & $311(66$ minta $)$ & $143(18$ minta $)$ & $218(40$ minta $)$ & $57(9$ minta $)$ & 729 \\
2. dúsító & $11(4$ minta $)$ & $86(11$ minta $)$ & - & - & 97 \\
\hline összesen & $322(66$ minta $)$ & $229(18$ minta $)$ & $218(40$ minta $)$ & $57(9$ minta $)$ & 826
\end{tabular}

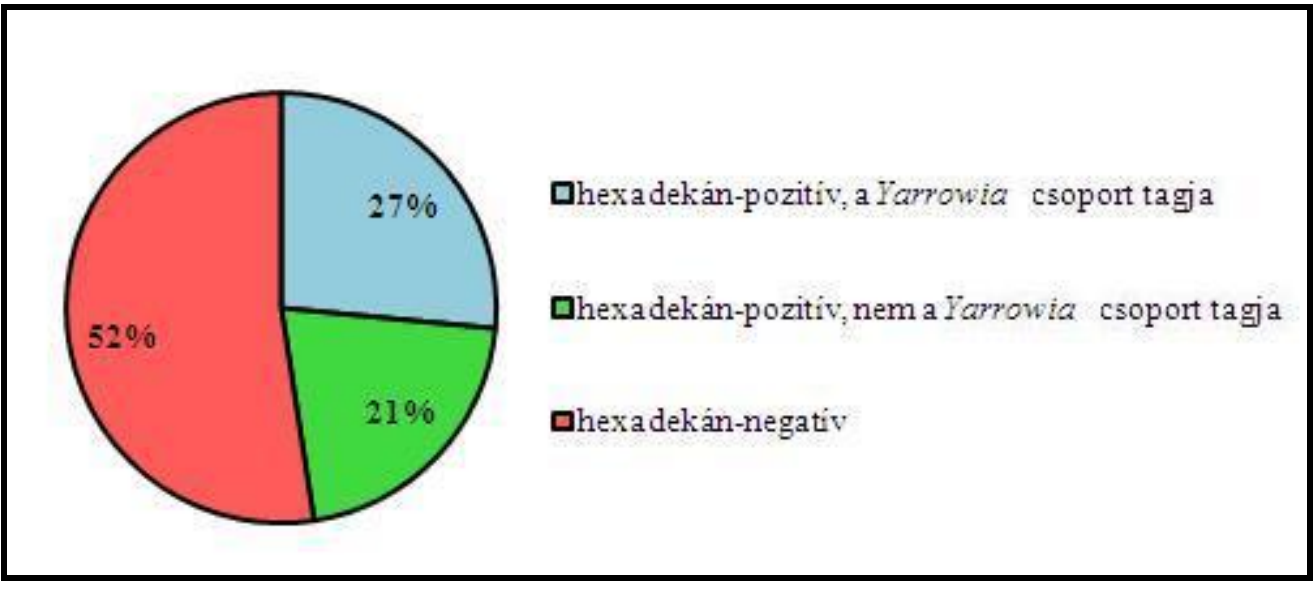

14. ábra. Az összes izolált élesztőgomba törzs megoszlása

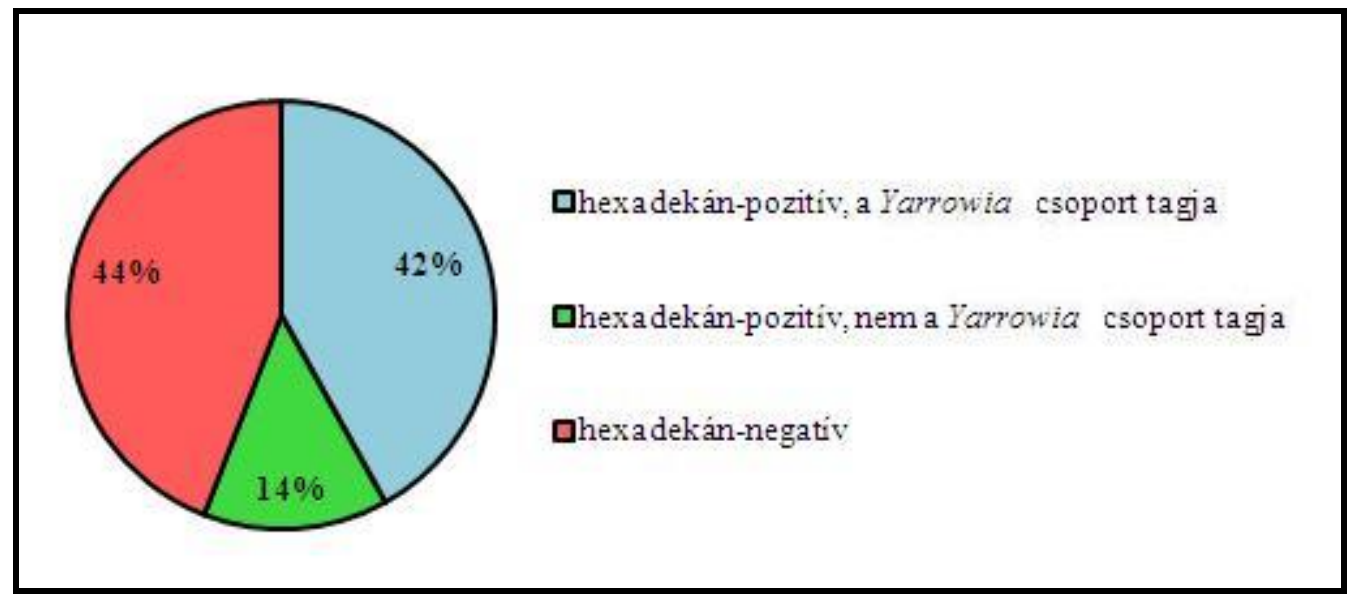

15. ábra. Nyers húsból izolált összes élesztőgomba törzs megoszlása 


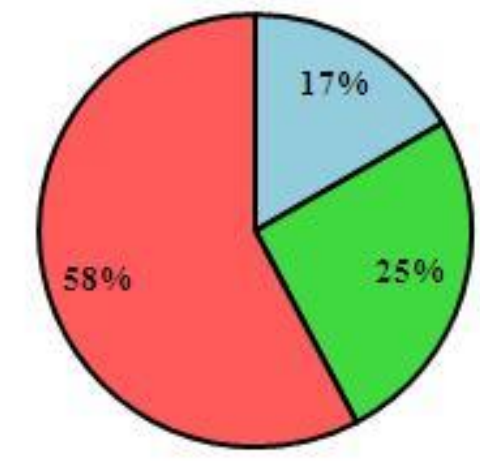

Qhexadekán-pozitiv, a Yarrowia csoport tagja

口hexadekan-pozitiv, nem a Yarrowia csoport tagia

Qhexadekán-negativ

16. ábra. Tejtermékből izolált összes élesztőgomba törzs megoszlása

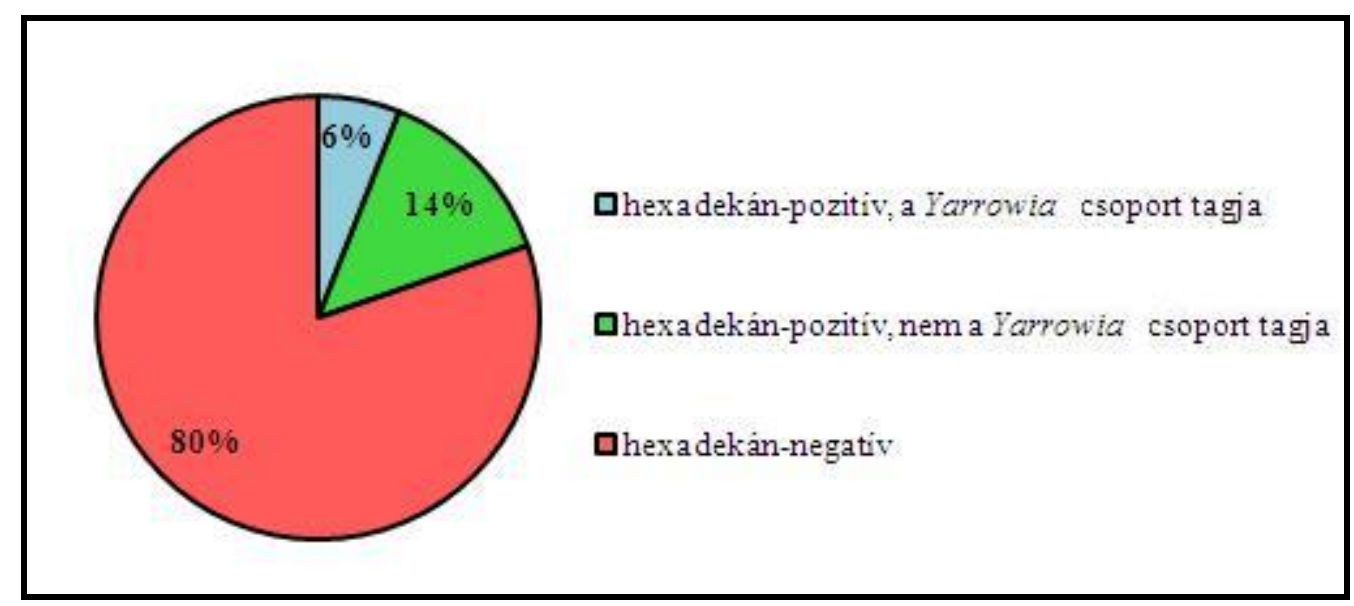

17. ábra. Nyers tejből izolált összes élesztőgomba törzs megoszlása

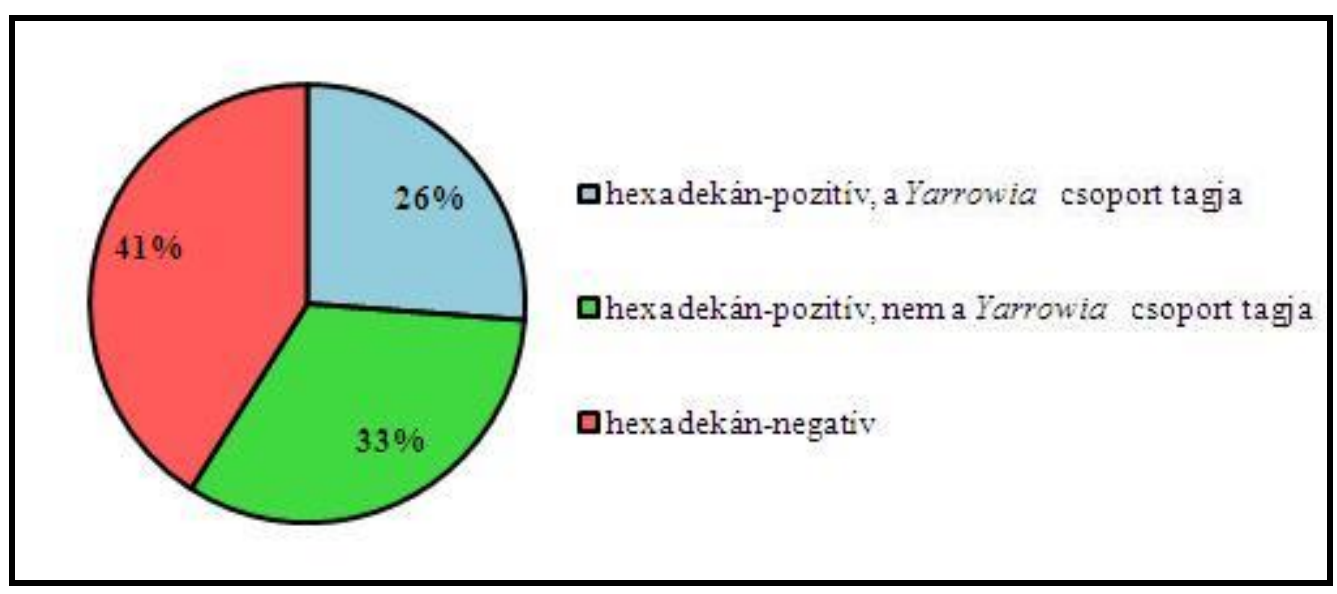

18. ábra. Túróból izolált összes élesztőgomba törzs megoszlása 


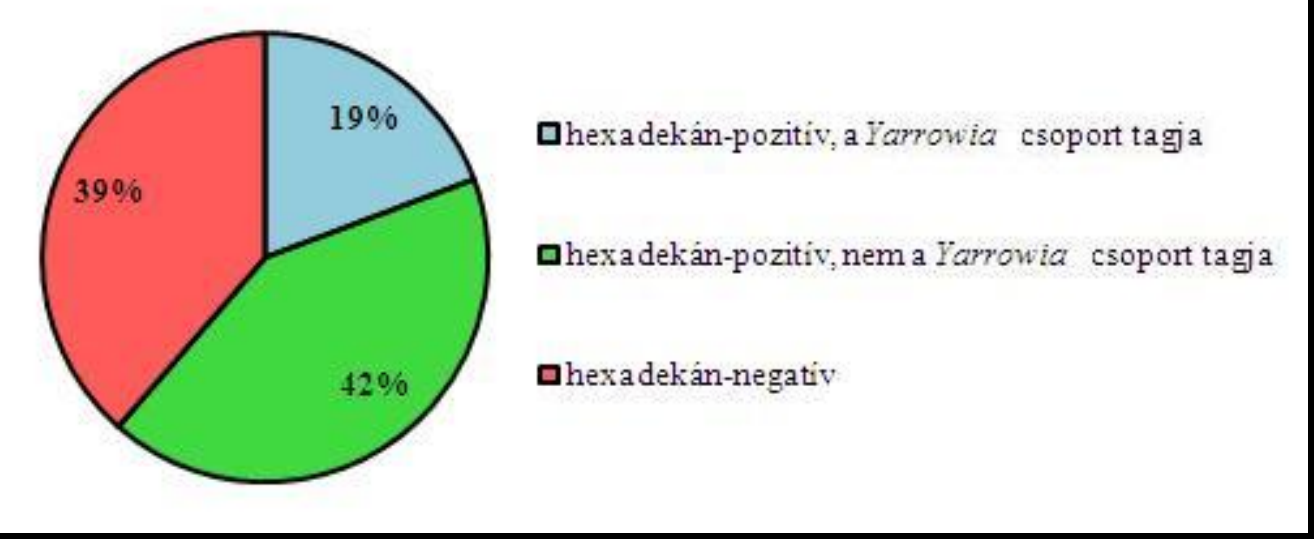

19. ábra. Sajtból izolált összes élesztőgomba törzs megoszlása

\subsection{A Yarrowia csoportba tartozó törzsek csoportosítása MP-PCR módszerrel}

A fiziológiai jellemzőik alapján a Yarrowia csoportba sorolt 219 élesztőgomba törzset 7 csoportba lehetett sorolni (GAC) 5 mikroszatellit primer és a 4.2.7.2. pontban ismertetett PCR paraméterek alkalmazásával elvégzett mikroszatellit-PCR segítségével való felszaporítása után, a megsokszorozott fragmentek agaróz gélelektroforézissel kapott mintázata alapján. A 10. táblázat mutatja, hogy hány törzs tartozott az egyes csoportokba.

10. táblázat. Az egyes csoportokba sorolt törzsek száma

\begin{tabular}{c|c|c|c|c|c|c|c} 
Csoportok sorszáma & I. & II. & III. & IV. & V. & VI. & VII. \\
\hline Törzsek száma & 111 & 43 & 15 & 20 & 6 & 16 & 8
\end{tabular}

Ugyanezzel a módszerrel a Yarrowia csoport típustörzseinek vizsgálatát is elvégeztem, a kapott mintázatokat összehasonlítottam az általam izolált Yarrowia csoportba tartozó élesztőgomba törzsek mintázataival.

A 20. ábrán láthatók a Yarrowia csoport típustörzseinek MP-PCR termékeinek agarózgélelektroforézissel kapott mintázatai, melyek alapján egyértelmüen el lehet különíteni egymástól a Yarrowia csoportba tartozó fajokat.

A 21. ábrán látható mind a hét mikroszatellit csoportból 2-2 törzs és a Yarrowia csoport típustörzseinek mintázatai. Bizonyos izolátumok esetében valószínüsíteni lehetett, hogy mely fajokhoz tartoznak, míg voltak olyan törzsek, melyek az akkor ismert fajoktól eltérő mintázatot mutattak. 


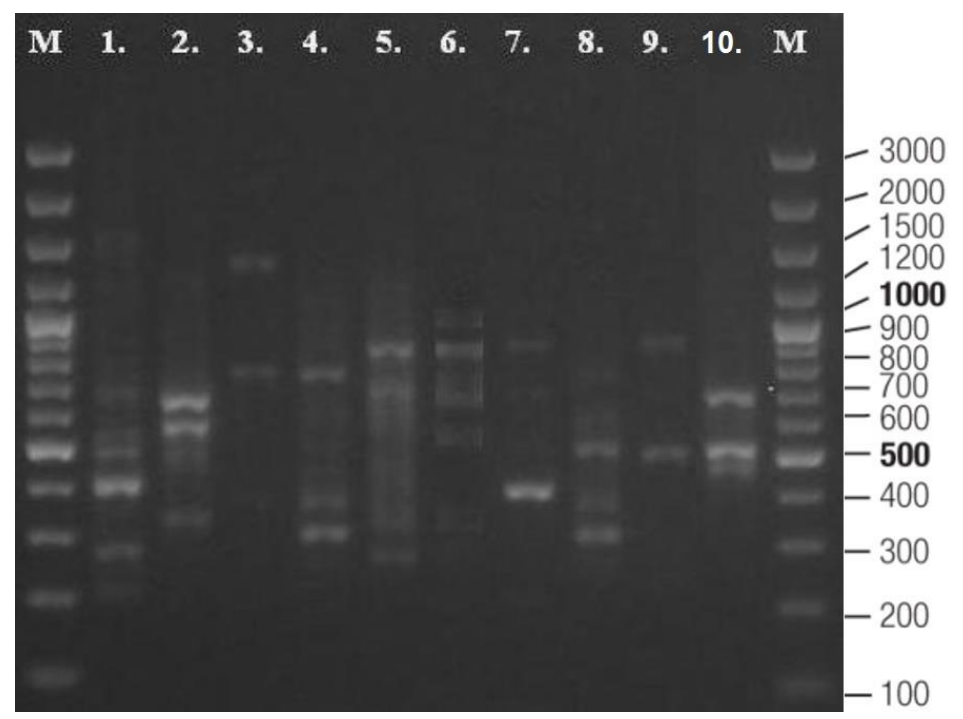

20. ábra. A Yarrowia csoportba tartozó fajok típustörzseiböl (GAC) 5 primer felhasználásával felszaporított DNS fragmentumok gélelektroforézissel nyert mintázata.

M: méretsztenderd, 1. Y. lipolytica NCAIM Y.00591 ${ }^{\mathrm{T}}$, 2. Y. deformans NCAIM Y.02005 ${ }^{\mathrm{T}}$, 3. C. galli NCAIM Y.01482 ${ }^{\mathrm{T}}$, 4. C. alimentaria JCM $10151^{\mathrm{T}}$, 5. C. hispaniensis NRRL4-5580 ${ }^{\mathrm{T}}$, 6. C. hollandica CBS4855 ${ }^{\mathrm{T}}$, 7. C. oslonensis $\mathrm{CBS} 10146^{\mathrm{T}}$, 8. C. phangngensis $\mathrm{CBS} 10407^{\mathrm{T}}$, 9. Y. yakushimensis $\mathrm{JCM} 12782^{\mathrm{T}}$, 10. Y. keelungensis CBS11062 ${ }^{\mathrm{T}}$.

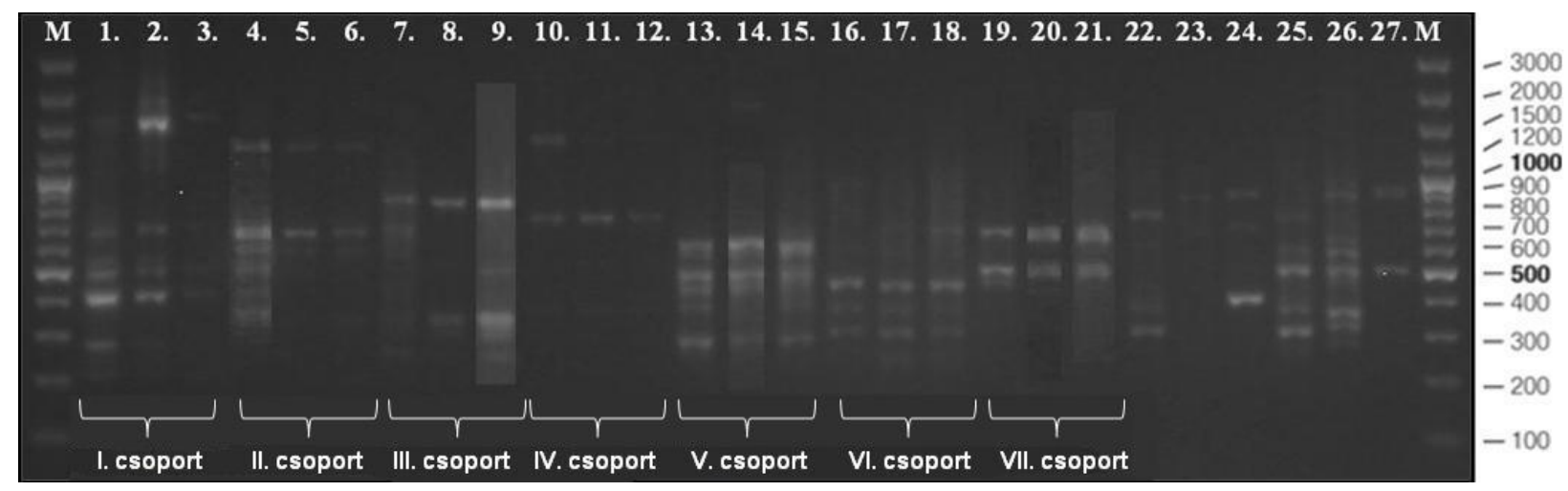

21. ábra. A hét mikroszatellit csoportba tartozó törzsek és a Yarrowia csoport típustörzseiböl (GAC)5 primer felhasználásával felszaporított DNS fragmentumok gélelektroforézissel nyert mintázatai

M: méretsztenderd, 1. Y. lipolytica NCAIM Y.00591 T , 2. I. csoport 148/4, 3. I. csoport 854/4, 4. Y. deformans NCAIM Y.02005 T , 5. II. csoport 440/2, 6. II. csoport 435/1, 7. C. alimentaria JCM 10151 T , 8. III. csoport 440/1, 9. III. csoport 450/5, 10. C. galli NCAIM Y.01482 T, 11. IV. csoport 437/3, 12. IV. csoport 435/4, 13. V. csoport F6-17

T, 14. V. csoport 864/2, 15. V. csoport 862/1, 16. VI. csoport 859/5, 17. VI. csoport 855/1, 18. VI. csoport 863/1, 19. VII. csoport NCAIM Y.01998, 20. VII. csoport 855/3, 21. VII. csoport 863/1, 22. C. hispaniensis NRRL4-5580

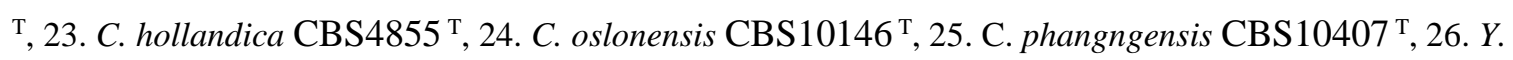
yakushimensis JCM12782 ${ }^{\mathrm{T}}$, 27. Y. keelungensis $\mathrm{CBS} 11062^{\mathrm{T}}$. T: típustörzs. 


\subsection{Az MP-PCR-rel csoportosított törzsek fajszintü azonosítása}

A fajszintủ azonosításhoz és így az egyes fajok arányának meghatározásához mind a hét csoport néhány kiválasztott tagjából felszaporítottam és szekvenáltattam a riboszómális RNS nagy alegységét kódoló gén D1/D2 régióját.

Az izolált Yarrowia csoportba tartozó élesztőgomba törzsek génszekvenciáit a GenBank adatbázisban található szekvenciákkal összehasonlítva az említett hét csoportnak megfelelően összesen 7 fajba lehetett sorolni. Közülük csak négy ( $Y$. lipolytica [I. csoport], $Y$. deformans [II. csoport], C. galli [III. csoport] és C. alimentaria [V. csoport]) volt akkor ismert faj, három új fajt ezt követöen írtunk le Yarrowia divulgata [VII. csoport] (Nagy et al. 2013), Yarrowia porcina [VI. csoport] és Yarrowia bubula [IV. csoport] néven (Nagy et al. 2014). Korábban, a hagyományos, fenotípusos tulajdonságokon alapuló azonosítási módszerekkel ezeknek a törzseknek a többsége $Y$. lipolytica-ként lett volna azonosítva, pedig valójában csak 51\%-uk (111 törzs a 219-ből) tartozik ebbe a fajba. Az e vizsgálat során izolált és Yarrowia csoportba sorolt élesztőgombatörzsek 26\%-a ( $Y$. deformans, Yarrowia divulgata és Yarrowia porcina) valószínűleg tévesen $Y$. lipolytica-ként lett volna azonosítva, mivel attól a sztenderd fenotípusos tesztek alapján nem különíthetők el.

A tejből és tejtermékekből izolált, fiziológiai tulajdonságaik alapján Yarrowia csoportba sorolt törzsek egy kivétellel (a Yarrowia csoport többi tagjától hagyományos módszerekkel is elkülöníthető $C$. alimentaria) mind a $Y$. lipolytica fajhoz tartoztak.

A húsból izolált törzsek nagyobb változatosságot mutattak. A nyers húsból izolált törzsek között a hét csoportnak megfelelően mind a hét fent említett faj képviseltette magát. A Yarrowia csoportba sorolt törzsek többsége $Y$. deformans és csak 21\%-uk $Y$. lipolytica (28 törzs a 135-böl). Kisebb számban volt köztük $C$. galli, $C$. alimentaria és három új faj tagjai (a pontos arányokat az 5.6. fejezetben ismertetem). A húsból izolált, Yarrowia csoportba sorolt törzsek $42 \%$-a ( $Y$. deformans, $Y$. divulgata és $Y$. porcina) hagyományos módszereket alkalmazva valószínüleg hibásan lett volna azonosítva.

A Yarrowia csoport tagjainak azonosítása során azt tapasztaltam, hogy a kiválasztott törzsek szekvenciáinak GenBank adatbázisban található szekvenciákkal való összehasonlítása alapján történt azonosítás eredménye minden esetben megegyezett a törzsek MP-PCR segítségével kapott mintázata alapján történt előzetes azonosítással. Az egy fajhoz tartozó törzsek MP-PCR mintázatai között csak minimális mértékü eltérések fordultak elő és csak ritkán. A különböző fajokhoz tartozó törzsek mintázatai minden esetben különböztek egymástól. 


\subsection{Négy új faj kimutatása}

Az MP-PCR-rel kapott mintázatokat vizsgálva 31 törzs négy olyan mintázatot mutatott, ami eltért a Yarrowia csoportba tartozó akkor ismert fajok típustörzseinek mintázatától. A fajszintủ azonosítás során ezekről bebizonyosodott, hogy négy új fajt képviselnek. A munkám során izolált négy új faj közül három (Y. divulgata, Y. porcina és $Y$. bubula) került leírásra, a negyedik egyelőre nem, mivel csak egy törzset sikerült izolálnom belőle.

Az új fajok leírásához felhasznált törzsek és a Yarrowia csoport akkor ismert fajainak típustörzsei közti különbséget azok rRNS nagy alegységét kódoló gén D1/D2 régióinak és ITS régióinak szekvenciáinak összehasonlításával erősítettük meg. Fenotípusos tulajdonságaik hasonlósága ellenére D1/D2 és ITS szekvenciáik alapján három, a leírt fajoktól és egymástól jól elkölönült csoportot alkottak a Yarrowia csoporton belül.

Az első csoportba az általam izolált törzsek közül 6 törzs tarozik, melyek ITS és D1/D2 szekvenciája megegyezett néhány GenBank-ban található szekvenciával. Ezek közül három a MIMNG birtokában lévő, csirkemájból és csirkemellből korábban izolált törzs szekvenciája volt, egy pedig egy dán szalonna-feldolgozó üzemből izolált törzsé, öt pedig tengeri lelőhelyből származó törzseké volt, utóbbiak sajnos nem voltak elérhetők, így nem lehetett bevonni öket a vizsgálatba. A rendelkezésre álló, fajleíráshoz felhasznált törzsek ITS és D1/D2 szekvenciája teljes mértékben megegyezett, jelezve, hogy azonos fajhoz tartoznak. Szekvenciáikhoz az ismert fajok közül a Yarrowia (Candida) deformans szekvenciái voltak a leghasonlóbbak. A típustörzsek szekvenciáit összehasonlítva, az rRNS nagy alegységét kódoló génjeik D1/D2 régióik közti hasonlóság 97,0\%, ITS régióik szekvenciái közti hasonlóság 93,7\%, ezek alapján egyértelműen megállapítható, hogy az említett törzsek egy jól elkülöníthető, korábban ismeretlen faj tagjai. Ezeket a törzseket Yarrowia divulgata (Nagy et al. 2013) néven írtuk le.

A második csoportba 16 törzs tarozik. A fajleírás idején közülük még csak négy általam izolált törzs állt rendelkezésünkre, ezek ITS és D1/D2 szekvenciái teljes mértékben megegyeztek egymással és egy a MIMNG még leíratlan törzsének szekvenciáival, jelezve, hogy egy faj tagjai. Akár D1/D2, akár ITS szekvenciáikat a Yarrowia csoport akkor ismert fajainak szekvenciáival összehasonlítva minden esetben legalább 9\% különbség tapasztalható, ami alátámasztja, hogy egy új fajt képviselnek. Ezt a fajt az említett öt törzs alapján Yarrowia bubula néven írtuk le (Nagy et al. 2014).

A harmadik csoportba tartozó nyolc törzs közül a fajleíráshoz szükséges vizsgálatok idején hat törzs volt a birtokunkban, amelyek szekvenciái egy brazil folyó üledékéből izolált törzs szekvenciáival mutattak nagy hasonlóságot. Kismértékü eltérés volt az egyes törzsek 
szekvenciái között, többségük 0-3 szubsztitúciót mutatott, akár a D1/D2, akár az ITS régiót vizsgáltuk. Egy törzs szekvenciája mutatott nagyobb eltérést a D1/D2 régióban, ami alapján egy fajhoz való tartozásuk Kurtzman and Robnett (1998) meghatározása szerint valószínütlen, de összeillesztett ITS és D1/D2 szekvenciáik parsimony network analízisével megállapítható, hogy még így is egy fajhoz tartozónak tekinthetők ezek a törzsek. A legközelebbi rokon fajok ( $C$. galli, C. oslonensis és Y. keelungensis) D1/D2 és ITS szekvenciáihoz hasonlítva a típustörzsként kiválasztott törzs szekvenciáit, 4,2-6,9\% különbség tapasztalható, ami alátámasztja, hogy a vizsgált törzsek egy harmadik új fajt képviselnek, amit Yarrowia porcina néven írtunk le (Nagy et al. 2014). Így az ismert és leírt Yarrowia csoportba tartozó fajok száma tízről tizenháromra nött.

A három leírt új fajt az alábbiakban mutatom be részletesebben.

\subsubsection{Yarrowia divulgata f.a.}

A fajleíráshoz használt öt törzs állati eredetű, vagy állatokkal összefüggésbe hozható. A típustörzset (F6-17 ${ }^{\mathrm{T}}$ ) Dániában izolálták egy szalonna feldolgozó üzemben (Nielsen et al. 2008). Az NCAIM Y.01485 és NCAIM Y.01487 törzseket egy korábbi vizsgálat során izolálták az Egyesült Államokban, a Georgia állambeli Griffinben (Ismail et al. 2000). Az NCAIM Y.02062 törzs csirkemellből és az NCAIM Y.02063 darált marhahúsból lett izolálva Magyarországon (11. táblázat).

11. táblázat. A Yarrowia divulgata f.a. leírásához figyelembe vett törzsek. Szaggatott vonallal jelöltem az általam izolált törzset. Forrás: Nagy et al. 2013.

A törzsek gyüjtemény száma Izolálás forrása és éve

F6-17 ${ }^{\mathrm{T}}\left(=\mathrm{CBS} 11013^{\mathrm{T}}=\right.$ CCUG 56725² $\quad$ szalonna feldolgozó üzem, Dánia, 2006

NCAIM Y.01485

csirkemáj, USA, Griffin, 1999

NCAIM Y.01487

csirkemáj, USA,Griffin, 1999

NCAIM Y.02062

csirkemell, Magyarország, Budapest, 2007

NCAIM Y.02063

darált marhahús, Magyarország, Budapest, 2011 
A fajleíráshoz felhasznált öt törzs D1/D2 szekvenciái teljes mértékben megegyeznek, jelezve, hogy egy faj tagjai. A GenBank adatbázisban kivitelezett BLAST keresés során találtunk néhány D1/D2 szekvenciát, (EU596435, EU583484, EU560880, EU360775, EU285507 és EU294124), melyek megegyeznek a vizsgált öt törzsével, ezért nagy valószínűséggel ugyanezen fajhoz tartoznak. Sajnos ezek a tengeri környezetből származó törzsek nem voltak elérhetők, nem tudtuk bevonni őket a vizsgálatainkba. A GenBank adatbázis alapján szekvenciáikhoz az ismert fajok közül a Yarrowia (Candida) deformans szekvenciái voltak a leghasonlóbbak, akár D1/D2, akár ITS szekvenciáikat hasonlítottuk össze. A Y. deformans típustörzsének (CBS 2071 ${ }^{\mathrm{T}}$ ) szekvenciáit az öt törzs szekvenciáival összehasonlítva, az rRNS nagy alegységét kódoló génjeik D1/D2 régióik köztött 3\% különbség van (501 nukleotid hosszúságú fragmentben 13 szubsztitúció és két inszerció található), ITS régióik szekvenciái közti különbség több mint $6 \%$ (304 nukleotid hosszúságú fragmentben 11 szubsztitúció és hét inszerció található). Kurtzman és Robnett (1998) és Daniel és munkatársai (2009) útmutatása szerint ilyen mértékü eltérés alapján egyértelműen megállapítható, hogy az említett törzsek egy jól elkülöníthető, korábban ismeretlen faj tagjai. Az új faj statisztikailag jól alátámasztva (97\% bootstrap) a Yarrowia csoportban, a $Y$. deformans mellett helyezkedik el az összeillesztett ITS és D1/D2 szekvenciáinak maximumparsimony analízise alapján szerkesztett fán (22. ábra).

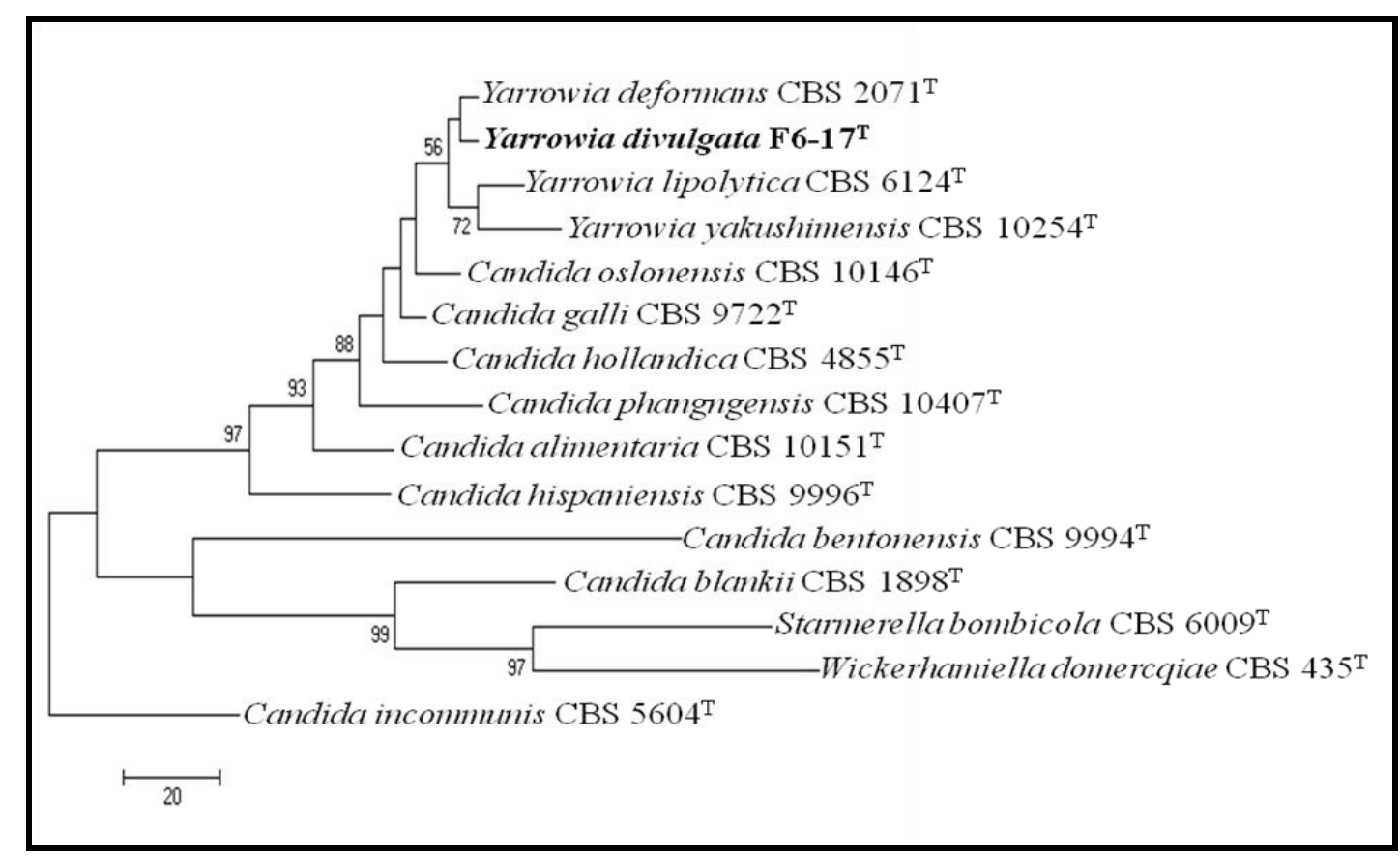

22. ábra. A Yarrowia divulgata f.a. és néhány rokon faj elhelyezkedését bemutató, azok ITS és az LSU rRNS gén D1/D2 régióinak összeillesztett szekvenciáin alapuló maximum-parsimony törzsfa. Lépték: 20 nukleotid szubsztitúció. Forrás: Nagy et al. 2013. 
Korábban a Candida bentonensis-t is a Yarrowia csoport tagjának tekintették (Kurtzman 2005; Kurtzman et al. 2011), bár fiziológiai tulajdonságai jelentősen különböznek a csoport többi tagjáétól. A Y. lipolytica és rokon fajok ITS és D1/D2 szekvenciáinak filogenetikai analízise nem támasztja alá a $C$. bentonensis Yarrowia csoportba való tartozását (21. ábra), nincs szoros rokonsági kapcsolatban a vizsgálatba bevont Yarrowia nemzetséggel és a Yarrowia csoportba tartozó Candida fajokkal. A C. bentonensis és Candida incommunis kivételével a Yarrowia csoporton kívüli referencia törzsek Kurtzman és Robnett (2013) multigén szekvencia analízise alapján lettek kiválasztva.

Az új faj négy törzse (és a később izolált, ugyanezen fajhoz tartozó törzsek is) melegvérü állatokból készült termékekből lett izolálva, csirkemájból, csirkemellből és darált marhahúsból, különböző földrajzi helyeken. A fajleíráshoz vizsgált ötödik törzs pedig szalonnát (szintén melegvérü állatból származó termék) feldolgozó üzemből. Ezt figyelembe véve megjegyzendő, hogy a törzsek nem képesek $35^{\circ} \mathrm{C}$-on vagy annál magasabb hőmérsékleten szaporodni. Ez azt sugallja, hogy ezek a törzsek másodlagos szennyeződés során kerültek a termékekre. Mivel a minták nem közvetlenül a húsfeldolgozó üzemböl származtak, hanem üzletekböl vagy minőségellenőrző laboratóriumból, az üzemek feldolgozó vonalait nem vizsgáltuk. Ezzel szemben a fent említett, az általunk vizsgált törzsek D1/D2 szekvenciáival megegyező szekvenciájú, minden valószínüség szerint konspecifikus törzsek tengeri élőhelyről származnak, mélytengeri vízből és óceáni halakból. Ezek az adatok arra utalnak, hogy a faj világszerte elterjedt és különböző élőhelyeken előfordul. A faj előfordulásáról a jelenleg rendelkezésre állónál több adatra lenne szükség ahhoz, hogy a melegvérü állatokból készült termékekben talált törzsek eredetére fény derüljön.

Az 5 vizsgált törzs közül négy makro- és mikromorfológiája megközelítőleg azonos, az ötödik enyhén eltérő morfológiát mutat. Az NCAIM Y.01487 törzs gyürt, enyhén kiemelkedő telepeket képez 5\%-os malátakivonat agaron (5\% malátakivonat, 2\% agar), míg a többi törzs, köztük a típustörzs $\left(\mathrm{F} 6-17^{\mathrm{T}}\right)$, majdnem teljesen sima, lapos telepeket képez ugyanezen agar felszínén. Csak néhány különbség mutatkozik a törzsek vizsgált fiziológiai jellemzői között, és ezek a különbségek néhány szénforráson (szalicin, arbutin, L-szorbóz, ribit, D-glucit, D-mannit, propán 1,2 diol, bután 2,3 diol) való szaporodóképesség sebességére és a szaporodás intenzitására korlátozódtak. Az új faj nem rendelkezik olyan fenotípusos tulajdonsággal, mellyel egyértelműen meg lehetne különböztetni a $Y$. lipolytica-tól vagy a $Y$. deformans-tól, így fenotípuson alapuló azonosítása nem megbízható. A rendelkezésre álló adatok alapján ez a faj csak az ITS és sejtmagi LSU rRNS gén D1/D2 régiója szekvenciái alapján ismerhető fel. 
Próbálkozásaink ellenére aszkospóraképzést nem tudtunk megfigyelni sem az egyes törzsekben, sem azok kevert tenyészeteiben. Ennek ellenére a növények és gombák nevezéktanának nemzetközi konszenzuson alapuló szabálykönyve, az Algák, Gombák és Növények Nevezéktanának Nemzetközi Kódja (McNeill et al. 2012) alapján az új faj a Yarrowia nemzetségbe sorolandó, de Lachance (2012) ajánlása alapján nevét a forma asexualis (f.a.) megjelöléssel is kiegészítettuik.

\section{A Yarrowia divulgata Nagy, Niss, Dlauchy, Arneborg, Nielsen \& Péter f.a., sp. nov. fajleírása}

MycoBank no.: MB 805642

A faj neve, Yarrowia divulgata (a latin „divulgatus” melléknév jelentése elterjedt), széleskörü földrajzi előfordulásra utal.

Három napon át $25{ }^{\circ} \mathrm{C}$-on inkubált 5\%-os malátakivonat táplevesben komplett vagy inkomplett felkúszó hártyát és üledéket képez. A sejtek alakja gömbölyü, gömbölyded vagy ellipszoid. Gömbölyü vagy gömbölyded alak esetén 2,5-6 $\mu$ m átmérőjüek, az ellipszoid sejtek 2,5-6,5 x 3,5$10 \mu \mathrm{m}$ méretúek. A sejtek egyesével, párokban, rövid láncokban vagy kis csoportokat alkotva fordulnak elő (23. ábra). A három napos $25{ }^{\circ} \mathrm{C}$-on inkubált 5\%-os malátakivonat agarra szélesztett tenyészet állaga vajszerü, felszíne a majdnem simától a gyürtig változhat, lapos vagy enyhén kiemelkedő, krémszínü, matt. A telep szegélye finoman lebenyezett, esetleg fonalas. Hét napon át inkubálva $25{ }^{\circ} \mathrm{C}$-on tárgylemeztenyészetben kukoricaliszt agaron valódi- és álhifát is képez (24. ábra). Aszkospórát nem képez.

Erjesztésre nem képes. Az asszimilált szénforrások a következők: D-glükóz, szalicin (lassú vagy gyenge és lassú és változó), arbutin (lassú vagy gyenge és lassú és változó), L-szorbóz (lassú vagy látens és változó), D-ribóz, etanol, glicerin, eritrit, ribit (lassú vagy gyenge és lassú és változó), D-szorbit (pozitív vagy lassú vagy látens), D-mannit (pozitív vagy lassú), DL-laktát, szukcinát, citrát, D-glükonát, glükono- $\delta$-lakton, N-acetil-D-glükózamin, propán 1,2 diol (pozitív vagy lassú vagy gyenge és lassú), bután 2,3 diol (lassú vagy gyenge és lassú és változó) és hexadekán.

Nem képes asszimilálni a következőket: inulin, szacharóz, raffinóz, melibióz, D-galaktóz, laktóz, $\alpha, \alpha$-trehalóz, maltóz, melezitóz, metil- $\alpha$-D-glükozid, keményítő, cellobióz, L-ramnóz, D-xilóz, L-arabinóz, D-arabinóz, metanol, xilit, galacit, myo-inosit, L-arabinit, 2-keto-D-glükonát, Dglükuronát, D-galakturonát, szacharát és D-glükózamin.

Nitrogénforrásként asszimilálja a következőket: etilamin hidroklorid, L-lizin és kadaverin dihidroklorid; nem asszimilálja a következőket: kálium-nitrát, nátrium-nitrit, kreatin, kreatinin, 
glükózamin és imidazol. Keményítőszerű anyagokat nem képez. Nem szaporodik vitaminmentes tápközegben. Képes $30{ }^{\circ} \mathrm{C}$-on szaporodni, de $35{ }^{\circ} \mathrm{C}$-on nem. Képes $0,1 \%$ cikloheximid vagy $10 \% \mathrm{NaCl}$ jelenlétében szaporodni. $50 \%$ w/w glükóz-élesztőkivonat agaron, $16 \% \mathrm{NaCl}$ vagy $1 \%$ ecetsav jelenlétében nem szaporodik. Urea hidrolízis és Diazonium Blue B színreakció negatív. Kalcium-karbonát tartalmú agaron nem mutatható ki savképzés. A típustörzs F6-17 ${ }^{\mathrm{T}}$ (=CBS $11013^{\mathrm{T}}=$ CCUG $56725^{\mathrm{T}}$ ) Dániában egy szalonna feldolgozó üzemben izolálták és metabolikusan inaktív állapotban van tartósítva.

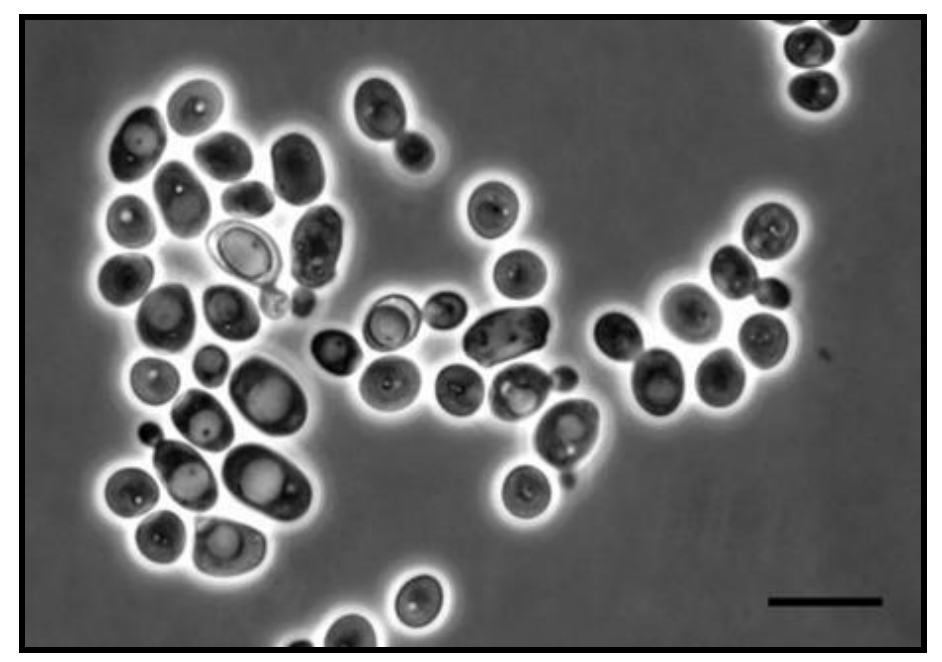

23. ábra. Yarrowia divulgata f.a. F6-17 ${ }^{\mathrm{T}}$ sarjadzó sejtjei 5\%-os malátakivonat agaron szaporítva 7 napig, $25^{\circ} \mathrm{C}$-on, lépték $10 \mu \mathrm{m}$. Fáziskontraszt mikroszkópos felvétel. Forrás: Nagy et al. 2013.

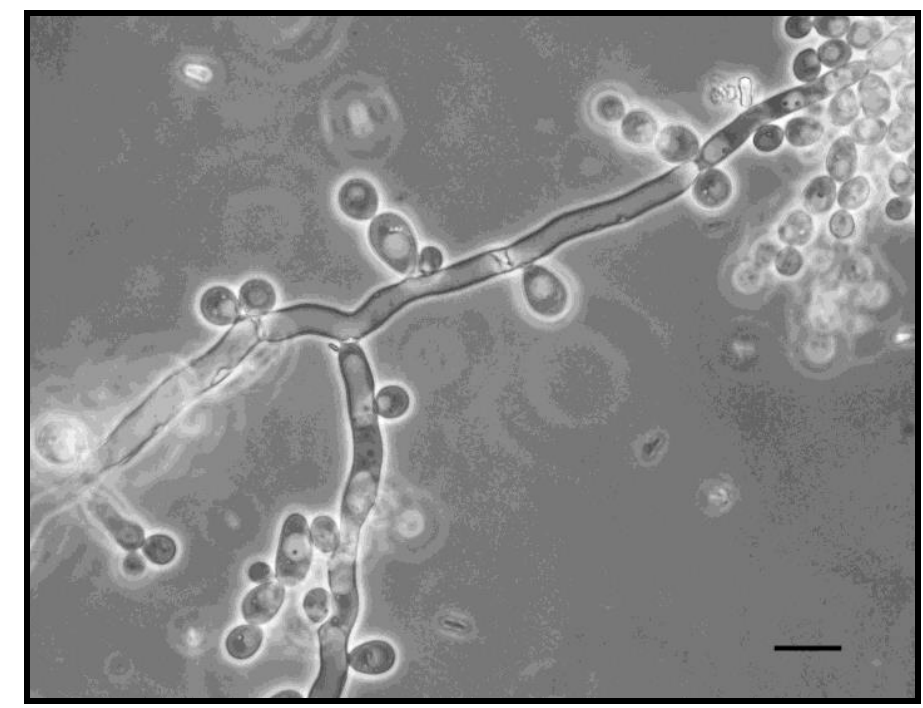

24. ábra. Yarrowia divulgata f.a. F6-17 $17^{\mathrm{T}}$ valódi- és álhifái kukoricaliszt agar tárgylemeztenyészetben 7 nap $25^{\circ} \mathrm{C}$-on történő inkubáció után, lépték $10 \mu \mathrm{m}$. Fáziskontraszt mikroszkópos felvétel. Forrás: Nagy et al. 2013. 


\subsubsection{Yarrowia porcina}

A faj leírása hét törzs alapján történt (NCAIM Y.02073, NCAIM Y.02100 ${ }^{\mathrm{T}}$, NCAIM Y.02101, NCAIM Y.02102, NCAIM Y.02103, NCAIM Y.02104, UFMG-RD131 ${ }^{\mathrm{A}}$ ). DNS szekvenciáik között kismértékü eltérés volt. A törzsek többsége akár a D1/D2, akár az ITS régiót vizsgálva 0-3 szubsztitúciót mutatott. Az NCAIM Y.02104 törzs D1/D2 régiója ennél valamivel nagyobb (5-7 nukleotid) szubsztitúciót mutatott. Az NCAIM Y.02104 törzs ITS fragmentje csak 0-2 nukleotidban különbözik a többi hat törzs ugyenezen szekvenciájától. Ezek alapján hat törzs tekinthető Kurtzman és Robnett (1998), valamint Daniel et al. (2009) szerint D1/D2 szekvenciáik alapján egy fajhoz tartozónak vagy legalább testvérfajoknak, míg a hét törzs ITS szekvenciái közti különbség nem nagyobb a fajon belüli általános értéknél (Daniel et al. 2009). Az rRNS géneket elválasztó ITS régiók (ITS 1 és ITS 2) általában gyorsabban változnak, mint a kódoló régiók (Chen et al. 2000), ezért szokatlan, hogy kisebb a különbség az ITS régió szekvenciái között, mint a D1/D2 régió szekvenciái között. Beszámoltak azonban néhány ennek ellentmondó esetről élesztőgombák esetében, melyeket az irodalmi áttekintésben ismertettem. Ezek alapján elképzelhető volt, hogy a hetedik törzs is ugyanehhez a fajhoz tartozik, de ennek bizonyításához további megerősítő vizsgálatokra volt szükség.

A törzsek (NCAIM Y.02073, NCAIM Y.02100" ${ }^{\mathrm{T}}$, NCAIM Y.02101, NCAIM Y.02102, NCAIM Y.02103, NCAIM Y.02104 és UFMG-RD131 A) egy fajhoz való tartozását bizonyítja összeillesztett ITS és D1/D2 szekvenciáinak parsimony network analízise (25. ábra). 95\%-os kapcsolódási határérték mellett mind a hét törzs része a hálózatnak nem úgy, mint a legközelebbi fajok (C. galli, $C$ oslonensis and $Y$. keelungensis) típustörzsei. A módszert számos élesztőgombafaj, például a Candida apicola, Candida azyma, Candida parazyma (Lachance et al. 2010) és a Metschnikowia agaves és Starmerella bombicola (Lachance et al. 2011) rokonsági fokának vizsgálatához használták, mely eredményeként azt a következtetést vonták le, hogy az összeillesztett ITS és D1/D2 szekvenciák parsimony network analízise élesztőgomba fajok filogenetikai meghatározásának elméleti alapokon nyugvó statisztikai megközelítését biztosítja. 


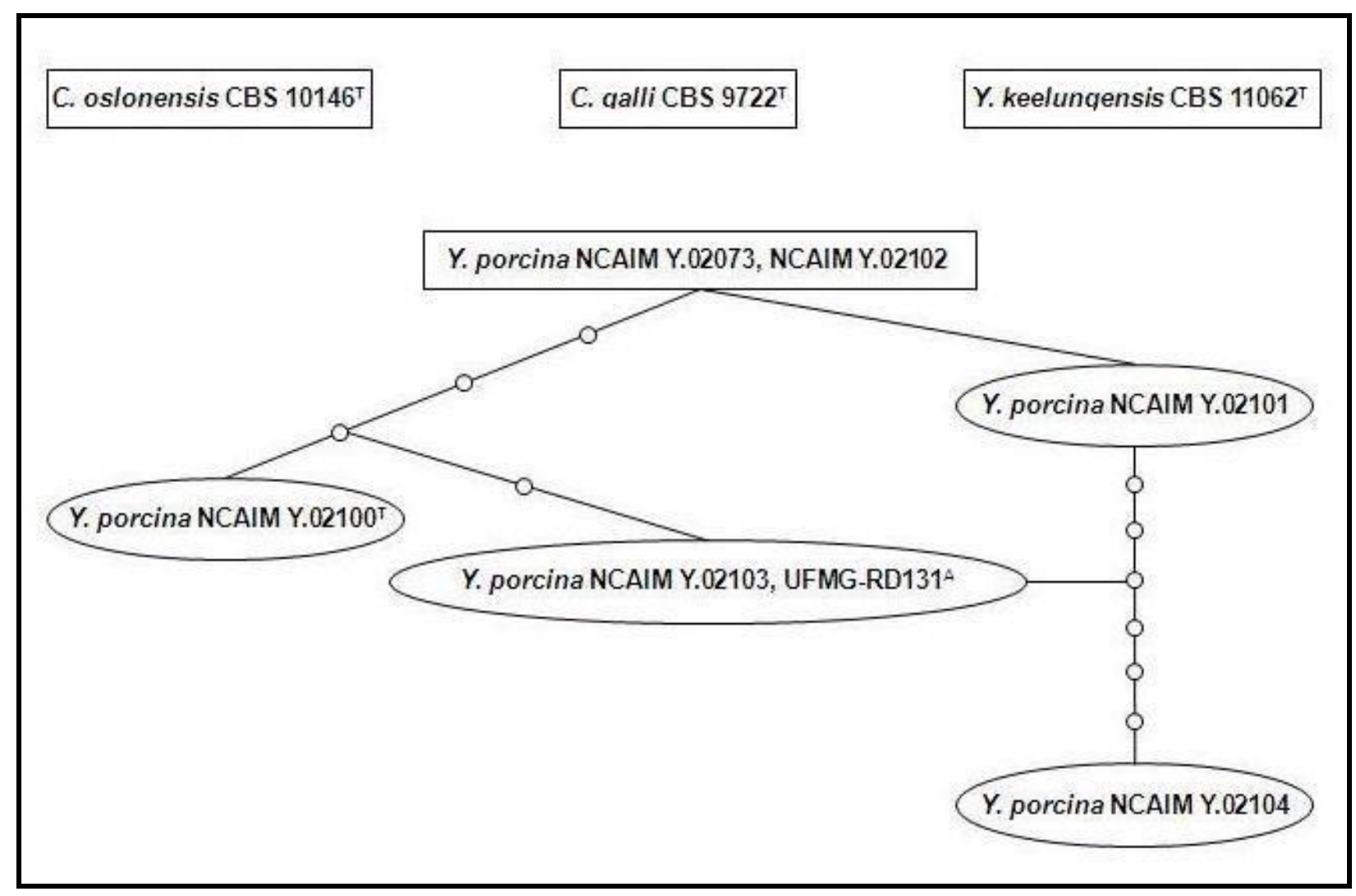

25. ábra. Yarrowia porcina és néhány közeli rokon faj (ITS) és az LSU rRNS gén D1/D2 régióinak összeillesztett szekvenciáin alapuló parsimony network analízisének eredménye. Minden összekötő vonal egy szubsztitúciót jelöl, a kis körök pedig egy-egy hiányzó közbülső szekvenciát. A téglalap az analízis által ősiként azonosított szekvenciákat jelöli. Forrás: Nagy et al. 2014.

Az Yarrowia porcina összeillesztett ITS és D1/D2 szekvenciáinak maximum-parsimony analízise alapján a Yarrowia csoportban helyezkedik el (26. ábra). 


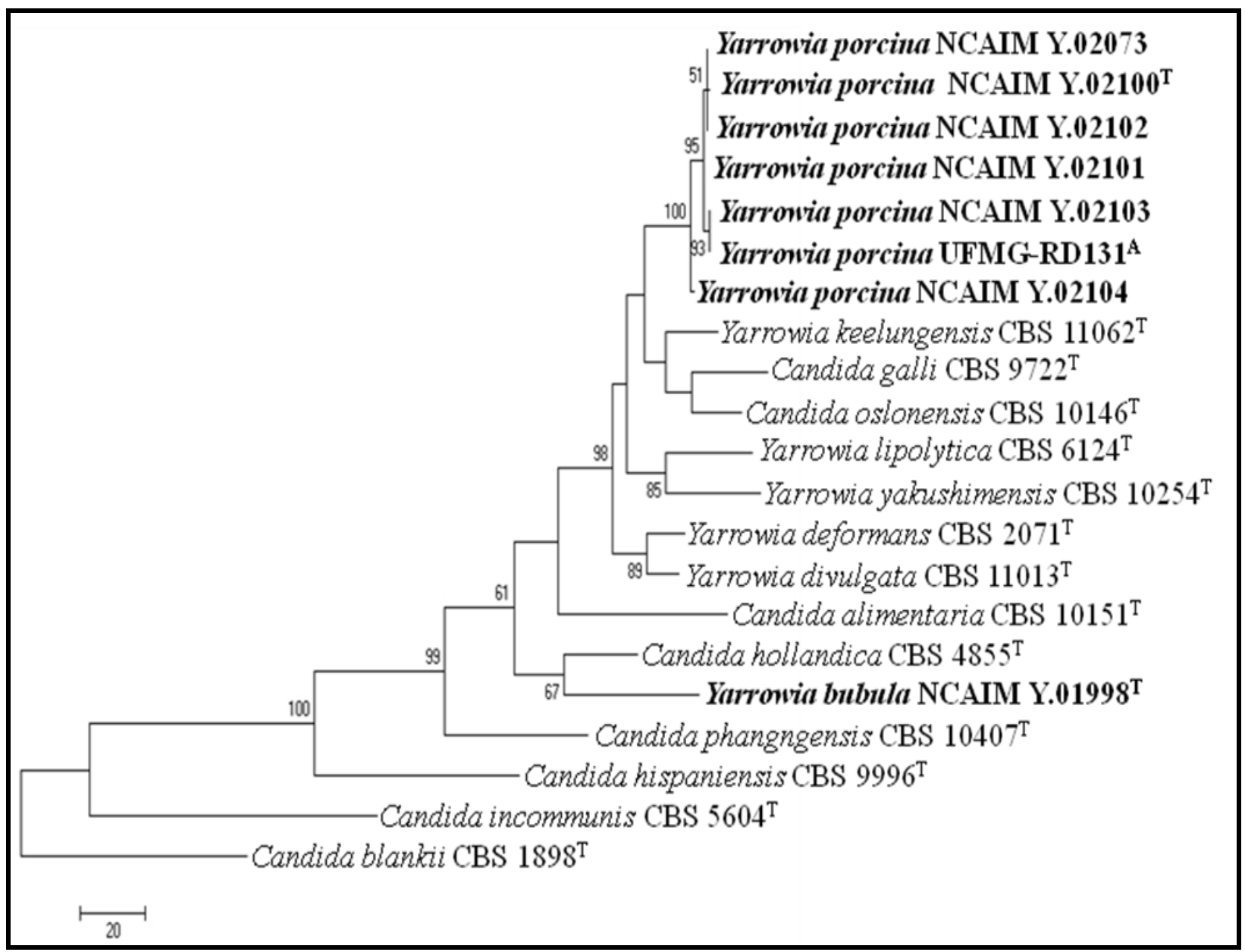

26. ábra. A Yarrowia porcina és Yarrowia bubula, f.a. és rokon fajok elhelyezkedését bemutató, azok (ITS) és az LSU rRNS gén D1/D2 régióinak összeillesztett szekvenciáin alapuló maximum-parsimony törzsfa. Lépték: 20 bázis szubsztitúció. Forrás: Nagy et al. 2014.

A Y.02100 ${ }^{\mathrm{T}}$ törzs és a legközelebbi ismert fajok (C. galli, C. oslonensis and Y. keelungensis) típustörzseinek D1/D2 és ITS szekvenciái közti különbség a szekvenciákat páronként összehasonlítva 4,2 és 6,9\% között változik, ami alátámasztja, hogy a fent említett hét törzs egy genetikailag elkülönült fajt alkot.

A fent említett hét törzs egy fajhoz tartozásának további megerősítéseként szolgálnak (GTG)5 primerrel való sokszorosítással nyert nagyon hasonló genetikai ujjlenyomatok, melyek jelentősen különböztek a $C$. galli és $C$. oslonensis típustörzsekétől (27. ábra). 


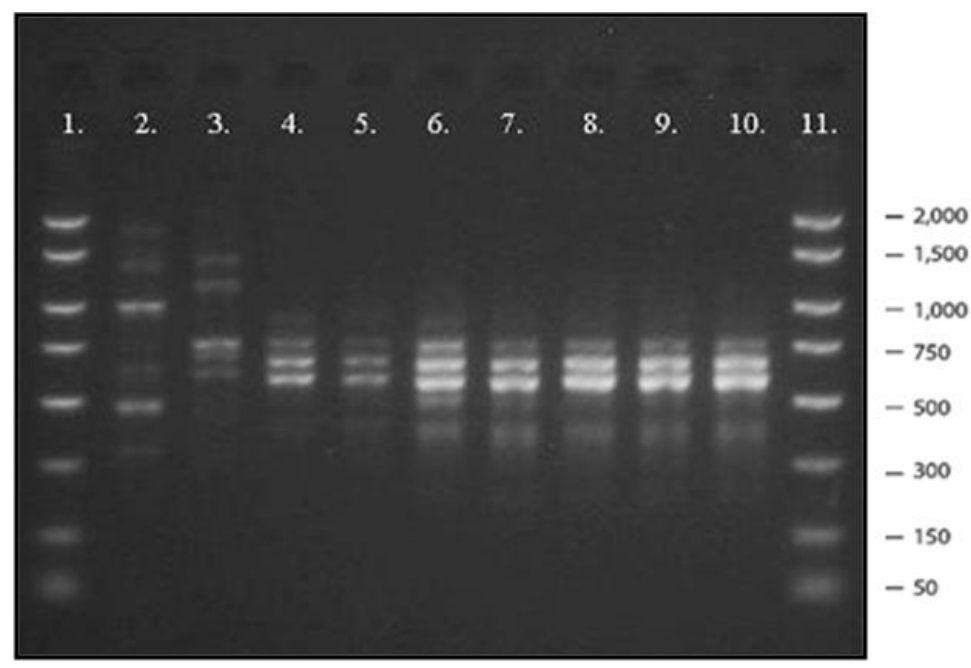

27. ábra. (GTG)5 primerrel való sokszorosítással kapott fragmentek gélelektroforézisével előállított PCR ujjlenyomatok. 1. és 11. molekula méret sztenderd (Sigma P-9577), 2. Candida oslonensis CBS $10146^{\mathrm{T}}$, 3. C. galli CBS 9722 ${ }^{\mathrm{T}}$, 4.-10. Yarrowia porcina; 4. NCAIM Y.02100 ${ }^{\mathrm{T}}$, 5. UFMG-RD131 A, 6. NCAIM Y.02073, 7. NCAIM Y.02101, 8. NCAIM Y.02102, 9. NCAIM Y.02103, 10. NCAIM Y.02104. Forrás: Nagy et al. 2014.

A fajleíráshoz használt törzsek hasonló makro- és mikromorfológiával, fiziológiai jellemzőkkel rendelkeznek. Fenotípusos tulajdonságai alapján a $Y$. porcina nem különíthető el egyértelműen a $Y$. deformans-tól, $Y$. divulgata-tól, Y. keelungensis-től és a $Y$. lipolytica-tól, így a fenotípusos tulajdonságokon alapuló azonosítás nem megbízható. D1/D2 és ITS szekvenciái alapján ismerhető fel.

\section{Yarrowia porcina Nagy, Dlauchy, Medeiros, Péter, \& Rosa, sp. nov. fajleírása}

MycoBank no.: MB 807595

A faj neve, Yarrowia porcina (a latin „porcinus” melléknév sertéshúsból származót jelent) a törzsek többségének, köztuik a típustörzsnek az izolálási forrására (sertéshús) utal.

5\%-os malátakivonat táplevesben 3 nap $25{ }^{\circ} \mathrm{C}$-on történő inkubációt követően üledéket és komplett vagy inkomplett felkúszó hártyát vagy gyürüt és néhány szigetet képez. Aszexuális szaporodása multilaterális sarjadzással megy végbe. A sejtek ellipszoidok, méretük 1,0-5,0 x 2,514,0 $\mu \mathrm{m}$, egyesével, párokban, rövid láncokban vagy kis csoportokat alkotva fordulnak elő. Rövid álhifát és valódi hifát képez (28. ábra). A három napos $25{ }^{\circ} \mathrm{C}$-on inkubált $5 \%$-os malátakivonat agarra szélesztett tenyészet állaga vajszerü, krémszínü, felszíne a simától vagy enyhén érdestől a gyürtig és fonalasig változhat, lapos vagy enyhén kiemelkedő, matt vagy enyhén fénylő. A telep szegélye ép vagy fonalas, esetleg enyhén lebenyes. 


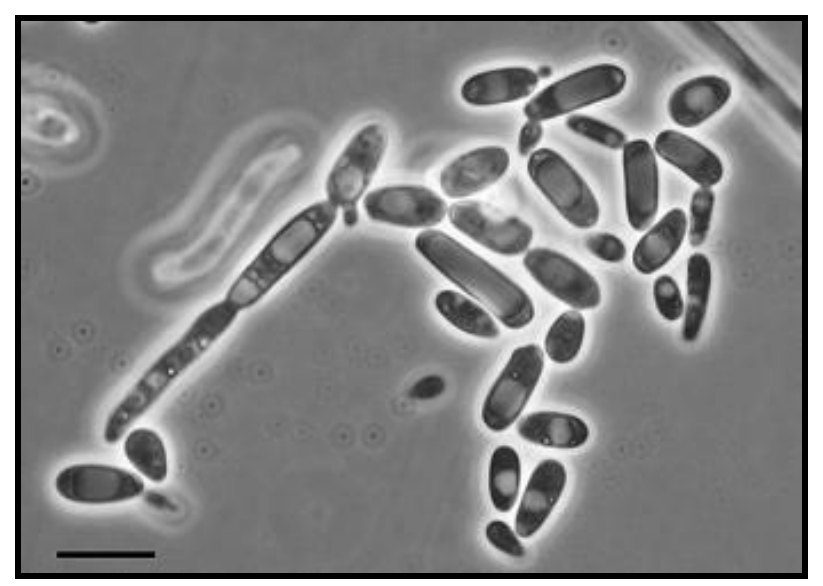

28. ábra. A Yarrowia porcina NCAIM Y.02100 ${ }^{\mathrm{T}}$ sarjadzó sejtjei, 5\% maláta kivonat agaron, 3 nap, $25^{\circ} \mathrm{C}$-on történt inkubáció után, lépték $10 \mu \mathrm{m}$. Fáziskontraszt mikroszkópos felvétel.

Forrás: Nagy et al. 2014.

Hét napon át $25^{\circ} \mathrm{C}$-on inkubálva tárgylemeztenyészetben kukoricaliszt agaron valódi- és álhifát is képez.

A D-glükóz erjesztésére nem képes. Asszimilált szénforrások a következők: D-glükóz, Dgalaktóz (lassú vagy gyenge és lassú és változó), L-szorbóz (változó), D-glükózamin, (változó), N-acetil-D-glükózamin, D-ribóz, cellobióz, szalicin (változó), arbutin (változó), glicerin, eritrit, ribit (lassú vagy látens és változó), xilit (lassú vagy gyenge és lassú és változó), D-glucit (változó), D-mannit, glükono- $\delta$-lakton (pozitív vagy lassú), D-glükonát (lassú vagy látens és változó), DL-laktát, szukcinát, citrát, etanol, propán 1,2 diol (változó), hexadekán.

Nem képes asszimilálni a következőket: D-xilóz, L-arabinóz, D-arabinóz, L-ramnóz, szacharóz,

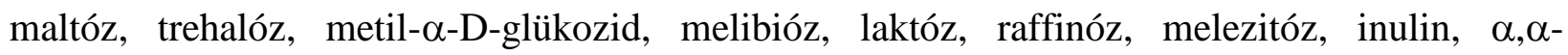
keményítő, L-arabinit, galacit, myo-inosit, 2-keto-D-glükonát, D-glükuronát, D-galakturonát, szaccharát, metanol és bután 2,3 diol.

Nitrogénforrásként asszimilálja a következőket: etilamin hidroklorid, L-lizin és kadaverin dihidroklorid; nem asszimilálja a következőket: kálium-nitrát, nátrium-nitrit, kreatin, kreatinin, glükózamin és imidazol. Keményítőszerü anyagokat nem képez. Mind a hét $Y$. porcina törzs képes $30{ }^{\circ} \mathrm{C}$-on szaporodni, de $35{ }^{\circ} \mathrm{C}$-on csak a Brazíliában izolált törzs (UFMG-RD131 ${ }^{\mathrm{A}}$ ) szaporodik. Képes $0,1 \%$ cikloheximid vagy $10 \%$ NaCl-ot és $5 \%$ glükózt tartalmazó yeast nitrogen base tápközegben szaporodni. Nem szaporodik vitaminmentes vagy $50 \%$ w/w glükózélesztőkivonat agaron, 16\% NaCl-ot vagy 1\% ecetsavat tartalmazó tápközegben.

Urea hidrolízis és Diazonium Blue B színreakció negatív. Kalcium-karbonát tartalmú agaron nem mutatható ki savképzés. 
A faj heterotallikus, aszkospórák a kompatibilis párosodási típusok összekeverése után képződnek. Az egyes törzsek nem képeznek aszkospórákat. Az aszkuszok hifán képződnek, alakjuk gömbölyded, ellipszoid, körte vagy buzogány alakú, faluk feloldódik. Méretük 3,5-6,0 x 9,5-17,0 $\mu \mathrm{m}$. Egy-négy ellipszoid, allantoid (görbült, kolbász alakú) vagy kalap alakú, tokanyagba ágyazott aszkospóra található bennük. A következő párok összekeverése után tapasztalható aszkospóraképzés: UFMG-RD131 ${ }^{\mathrm{A}}$ és NCAIM Y.02100 ${ }^{\mathrm{T}}$; UFMG-RD131 ${ }^{\mathrm{A}}$ és NCAIM Y.02103; UFMG-RD131 ${ }^{\mathrm{A}}$ és NCAIM Y.02104. YES agaron $25^{\circ} \mathrm{C}$-on hét nap inkubáció után kellő számú aszkospóra figyelhető meg (29. ábra).

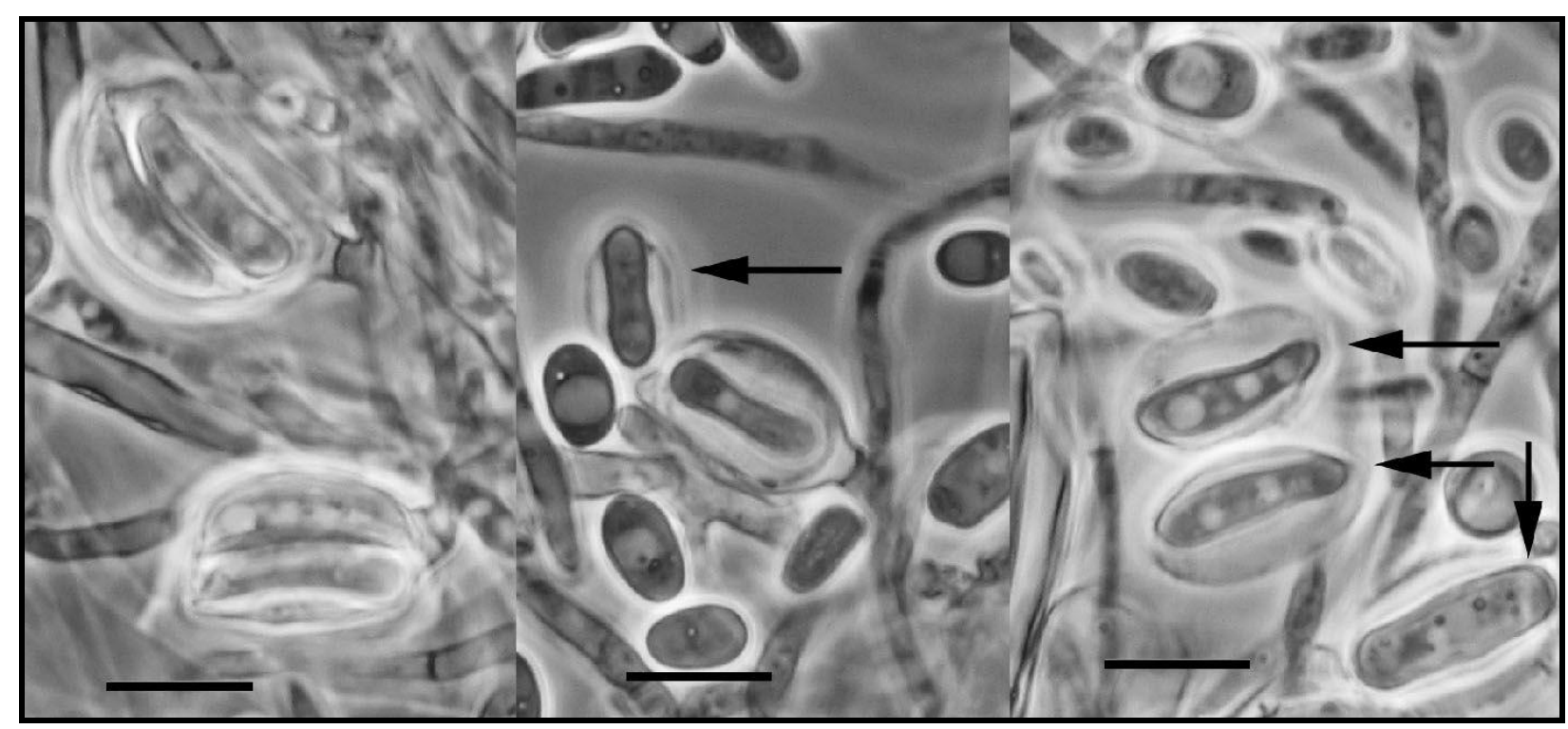

29. ábra. Az NCAIM Y.02100 és UFMG-RD131 ${ }^{\mathrm{A}}$ Yarrowia porcina törzsek aszkosporulációja, YES agaron, $25^{\circ} \mathrm{C}$-on, 7 nap után. Lépték $10 \mu \mathrm{m}$. A kép középső részén és jobb szélén szereplő nyilak a tokanyagba ágyazott, kiszabadult aszkospórákat mutatják. Fáziskontraszt mikroszkópos felvétel. Forrás: Nagy et al. 2014.

A típustörzs NCAIM Y.02100 ${ }^{\mathrm{T}}\left(=\mathrm{CBS} 12935^{\mathrm{T}}=\mathrm{NRRL}\right.$ Y-63669 $\left.{ }^{\mathrm{T}}\right)$ darált sertéshúsból lett izolálva Magyarországon, és metabolikusan inaktív állapotban van tartósítva. Az allotípus törzs UFMG-RD131 ${ }^{\mathrm{A}}$ (=CBS $\left.12932^{\mathrm{A}}\right)$ egy trópusi édesvizü folyó üledékéből származik, Minas Gerais-ból, Brazíliából. 


\subsubsection{Yarrowia bubula f.a.}

A faj leírásához felhasznált négy törzs (NCAIM Y.02105, NCAIM Y.02106, NCAIM Y.02107, NCAIM Y.02110) ITS és D1/D2 szekvenciái teljes mértékben megegyeztek egymással és egy a MIMNG még leíratlan törzsének szekvenciáival (NCAIM Y.01998), jelezve, hogy egy faj tagjai. Akár D1/D2, akár ITS szekvenciáikat a Yarrowia csoport ismert fajainak szekvenciáival összehasonlítva minden esetben legalább 9\% különbség tapasztalható, ami alátámasztja, hogy egy új fajt képviselnek.

A törzsek hasonló makro- és mikromorfológiával, fiziológiai jellemzőkkel rendelkeznek. Nem képesek $30{ }^{\circ} \mathrm{C}$-on szaporodni. A Yarrowia csoport tagjai közül még két faj nem képes ezen a hömérsékleten szaporodni ( $Y$. yakushimensis és $C$. alimentaria). A Y. bubula D-ribóz és N-acetilD-glükózamin asszimiláló képessége alapján különíthető el a $Y$. yakushimensis-től, a $C$. alimentaria-tól pedig D-mannit asszimiláló- és 10\%-os NaCl-ot tartalmazó tápközegben való szaporodóképessége alapján. Tekintettel arra, hogy lehetnek még eddig nem észlelt fajon belüli változatok és le nem írt rokon fajok, a Y. bubula megbízható azonosításához a D1/D2 és ITS szekvenciák vizsgálata ajánlott.

Aszkosporulációt nem figyeltünk meg a $Y$. bubula törzsek kevert tenyészetében a spóráztatáshoz használt fentebb felsorolt tápközegeken $15{ }^{\circ} \mathrm{C}$ vagy $25{ }^{\circ} \mathrm{C}$-on 3 héten át tartó inkubáció során. Annak ellenére, hogy ivaros szaporodás nem volt megfigyelhető, az Algák, Gombák és Növények Nevezéktanának Nemzetközi Kódja (McNeill et al. 2012) alapján az új faj a Yarrowia nemzetségbe sorolandó, de Lachance (2012) ajánlása alapján nevét a forma asexualis (f.a.) megjelöléssel is kiegészítettük. D1/D2 és ITS szekvenciái alapján megbízhatóan felismerhető.

\section{A Yarrowia bubula Nagy, Dlauchy, Péter f.a., sp. nov. fajleírása}

MycoBank no.: MB 807596

A faj neve, Yarrowia bubula (a latin „bubulus” melléknévből ered, aminek jelentése marhahúsból származó) a törzsek többségének, köztük a típustörzs izolálási forrására (marhahús) utal.

5\%-os malátakivonat táplevesben 3 nap $25{ }^{\circ} \mathrm{C}$-on történő inkubációt követően üledéket és komplett vagy inkomplett felkúszó hártyát vagy gyürüt és néhány szigetet képez.

Aszexuális szaporodása multilaterális sarjadzással megy végbe. A sejtek ellipszoidok, méretük 2,0-6,0 x 2,5-14,5 $\mu \mathrm{m}$, egyesével, párokban, rövid láncokban vagy kis csoportokat alkotva fordulnak elő (30. ábra). Rövid álhifát és valódi hifát képez. 


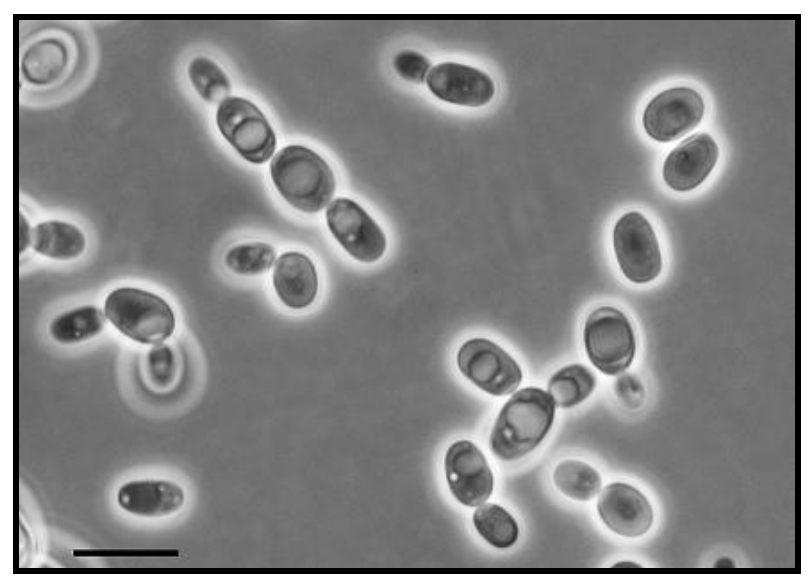

30. ábra. A Yarrowia bubula f.a. NCAIM Y.01998 ${ }^{\mathrm{T}}$ sarjadzó sejtjei, 5\% maláta kivonat agaron,

3 nap, $25^{\circ} \mathrm{C}$-on történt inkubáció után, lépték $10 \mu \mathrm{m}$. Fáziskontraszt mikroszkópos felvétel.

Forrás: Nagy et al. 2014.

A három napos $25{ }^{\circ} \mathrm{C}$-on inkubált 5\%-os malátakivonat agarra szélesztett tenyészet (szélesztés után kinőtt telepek) állaga vajszerü, krémszínü, felszíne a simától az enyhén érdesig változhat, lapos vagy enyhén kiemelkedő, matt vagy enyhén fénylő. A telep szegélye finoman lebenyes, esetleg fonalas. Hét napon át $25^{\circ} \mathrm{C}$-on inkubálva tárgylemeztenyészetben kukoricaliszt agaron valódi- és álhifát is képez. Aszkospórákat nem képez.

A D-glükóz erjesztésére nem képes. Asszimilált szénforrások a következők: D-glükóz, Dgalaktóz (lassú vagy gyenge és lassú és változó), L-szorbóz (lassú vagy változó), N-acetil-Dglükózamin, D-ribóz, szalicin (lassú vagy gyenge és lassú és változó), arbutin (lassú vagy gyenge és lassú és változó), glicerin, eritrit, ribit (pozitív vagy lassú vagy látens), xilit (változó), D-glucit (pozitív vagy lassú vagy gyenge és lassú), D-mannit (pozitív vagy lassú), glükono- $\delta$ lakton, D-glükonát (változó), DL-laktát, szukcinát, citrát, etanol, propán 1,2 diol (változó), hexadekán és bután 2,3 diol (lassú vagy változó).

Nem képes asszimilálni a következőket: D-glükózamin, D-xilóz, L-arabinóz, D-arabinóz, L-

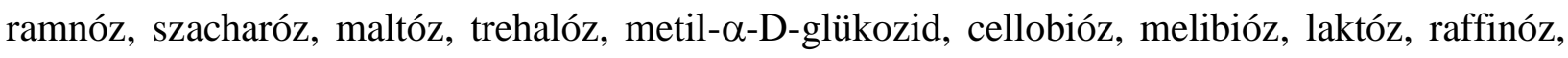
melezitóz, inulin, $\alpha, \alpha$ - keményítő, L-arabinit, galacit, myo-inosit, 2-keto-D-glükonát, Dglükuronát, D-galakturonát, szaccharát, metanol.

Nitrogénforrásként asszimilálja a következőket: etilamin hidroklorid, L-lizin és kadaverin dihidroklorid; nem asszimilálja a következőket: kálium-nitrát, nátrium-nitrit, kreatin, kreatinin, glükózamin és imidazol. Keményítőszerü anyagokat nem képez. Egyik törzs sem képes $30{ }^{\circ} \mathrm{C}$-on szaporodni vagy savat termelni. Képes $0,1 \%$ cikloheximid vagy $10 \% \mathrm{NaCl}$-ot és $5 \%$ glükózt tartalmazó yeast nitrogen base tápközegben szaporodni. Nem szaporodik vitaminmentes vagy $50 \%$ w/w glükóz-élesztőkivonat agaron, 16\% NaCl-ot vagy $1 \%$ ecetsavat tartalmazó 
tápközegben. Urea hidrolízis és Diazonium Blue B színreakció negatív. Kalcium-karbonátot tartalmazó agaron nem mutatható ki savképzés.

A típustörzs NCAIM Y.01998 ${ }^{\mathrm{T}}\left(=\mathrm{CBS} 12934^{\mathrm{T}}=\mathrm{NRRL}\right.$ Y-63668 $\left.{ }^{\mathrm{T}}\right)$ marhahúsból lett izolálva Magyarországon és metabolikusan inaktív állapotban van tartósítva.

D1/D2 és ITS szekvenciáinak vizsgálata alapján egy Yarrowia csoportba tartozó negyedik új fajhoz tartozó törzset is sikerült kimutatni, amihez szeretnénk további törzseket izolálni, hogy több törzs alapján leírhassuk ezt az új fajt is, tizennégyre növelve a Yarrowia csoport ismert fajainak számát.

\subsection{A Yarrowia csoportba tartozó fajok megoszlása a vizsgált élelmiszerekben}

A fiziológiai tesztek alapján Yarrowia csoportba tartozó törzseket MP-PCR felhasználásával sokszorozott DNS fragmentek gélelektroforézisével nyert mintázatuk alapján hét csoportba lehetett sorolni. Mind a hét csoportban képviseltették magukat a nyers húsból izolált törzsek, nyers tejből és tejtermékekből izolált törzseket viszont csak két csoportba lehetett sorolni, utóbbiak esetében az egyik csoportot egyetlen törzs képviselte.

A 31. és 32. ábrán néhány általam izolált törzsből (GAC)5 primer felhasználásával felszaporított DNS fragmentumok gélelektroforézissel nyert mintázata látható, az egyes törzsek mintázatának változatosságát mutatja be. A húsból izolált törzsek nagy változatosságot mutatnak, viszont a tejből és tejtermékből izolált törzsek mintázata egy kivételtől eltekintve megegyezik.

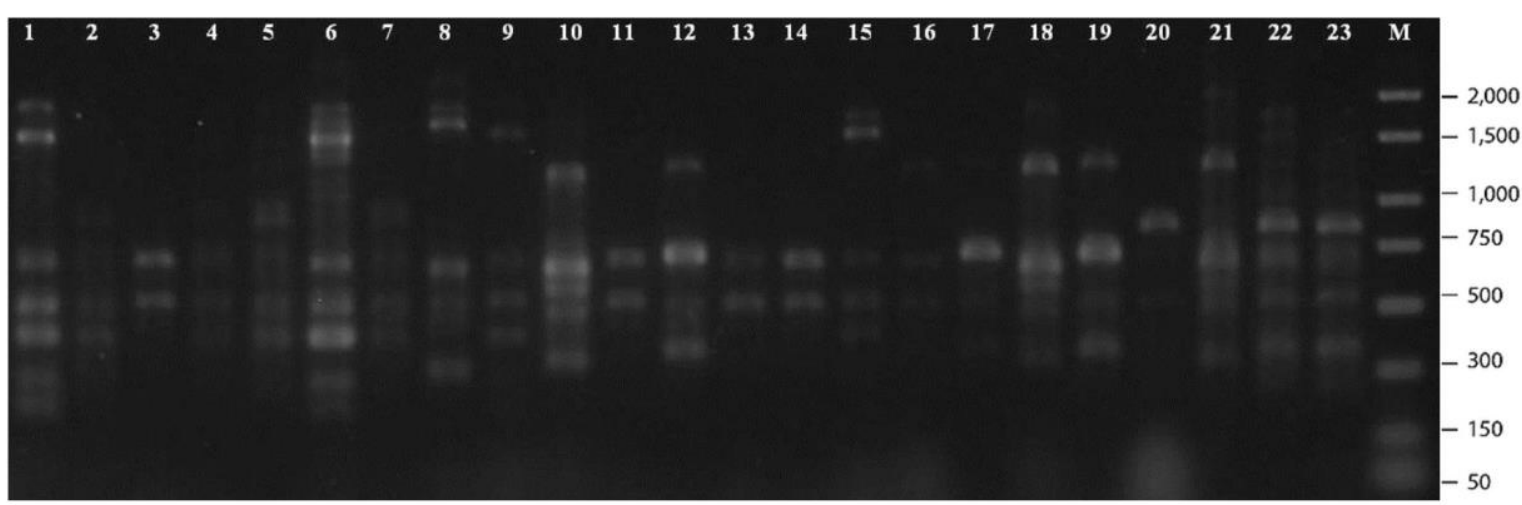

31. ábra. Néhány nyers húsból izolált Yarrowia csoportba tartozó törzsből (GAC) 5 primer felhasználásával felszaporított DNS fragmentumok gélelektroforézissel nyert mintázata.

1., 6., 9., 15., 17. oszlop: Yarrowia lipolytica; 2., 4., 5., 7. oszlop: Yarrowia porcina; 3., 11., 13., 14. oszlop: Yarrowia bubula; 8. oszlop: Yarrowia divulgata; 10., 16., 18., 21. oszlop: Yarrowia deformans; 12., 19. oszlop: Candida galli; 20., 22., 23. oszlop Candida alimentaria; M: molekula méretsztenderd. 


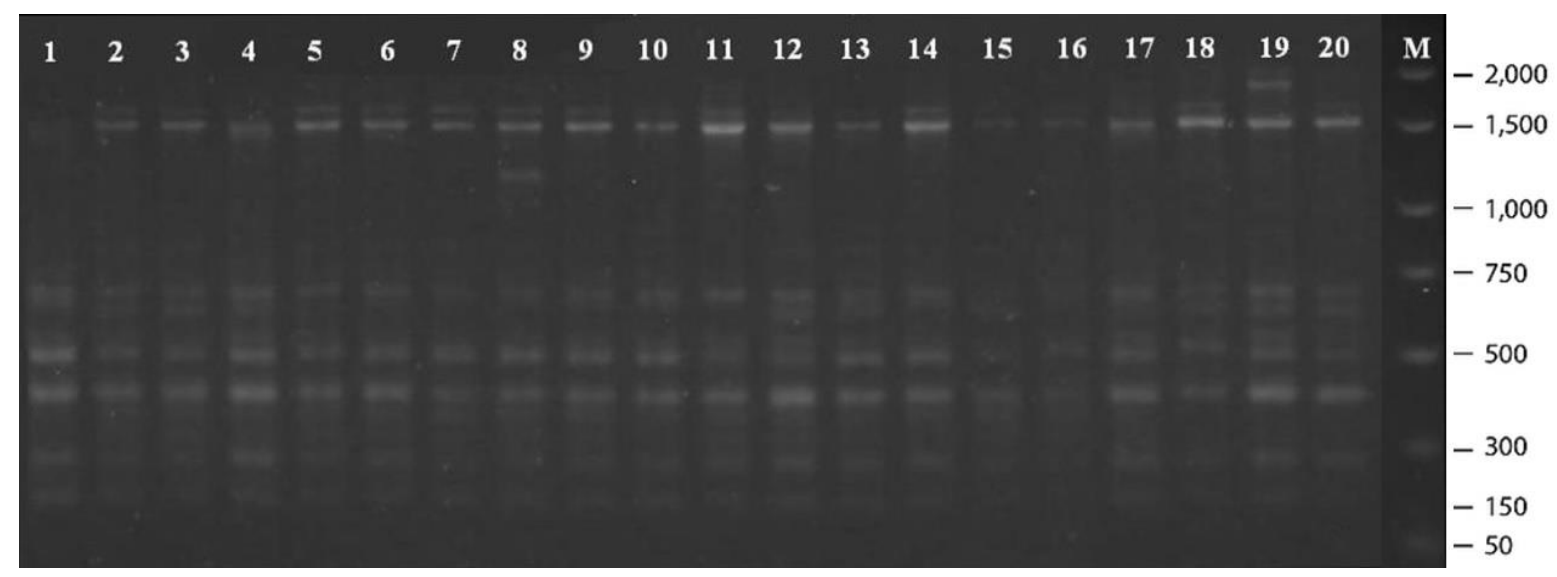

32. ábra. Néhány nyers tejből és tejtermékekből izolált törzsből (GAC) 5 primer felhasználásával felszaporított DNS fragmentumok gélelektroforézissel nyert mintázata.

1.-27. oszlop: Yarrowia lipolytica; M: molekula méret sztenderd.

A nyers húsból izolált Yarrowia csoportba tartozó törzsek 32\%-a Y. deformans (43 törzs), 21\%-a Y. lipolytica (28 törzs), 15\%-a C. galli (20 törzs), 10\%-a C. alimentaria (14 törzs), a maradék 22\% pedig a közelmúltban leírt (Nagy et al. 2013, 2014) három új fajhoz tartozik (12\% Y. bubula, 6\% Y. porcina, 4\% Y. divulgata) (33. ábra).

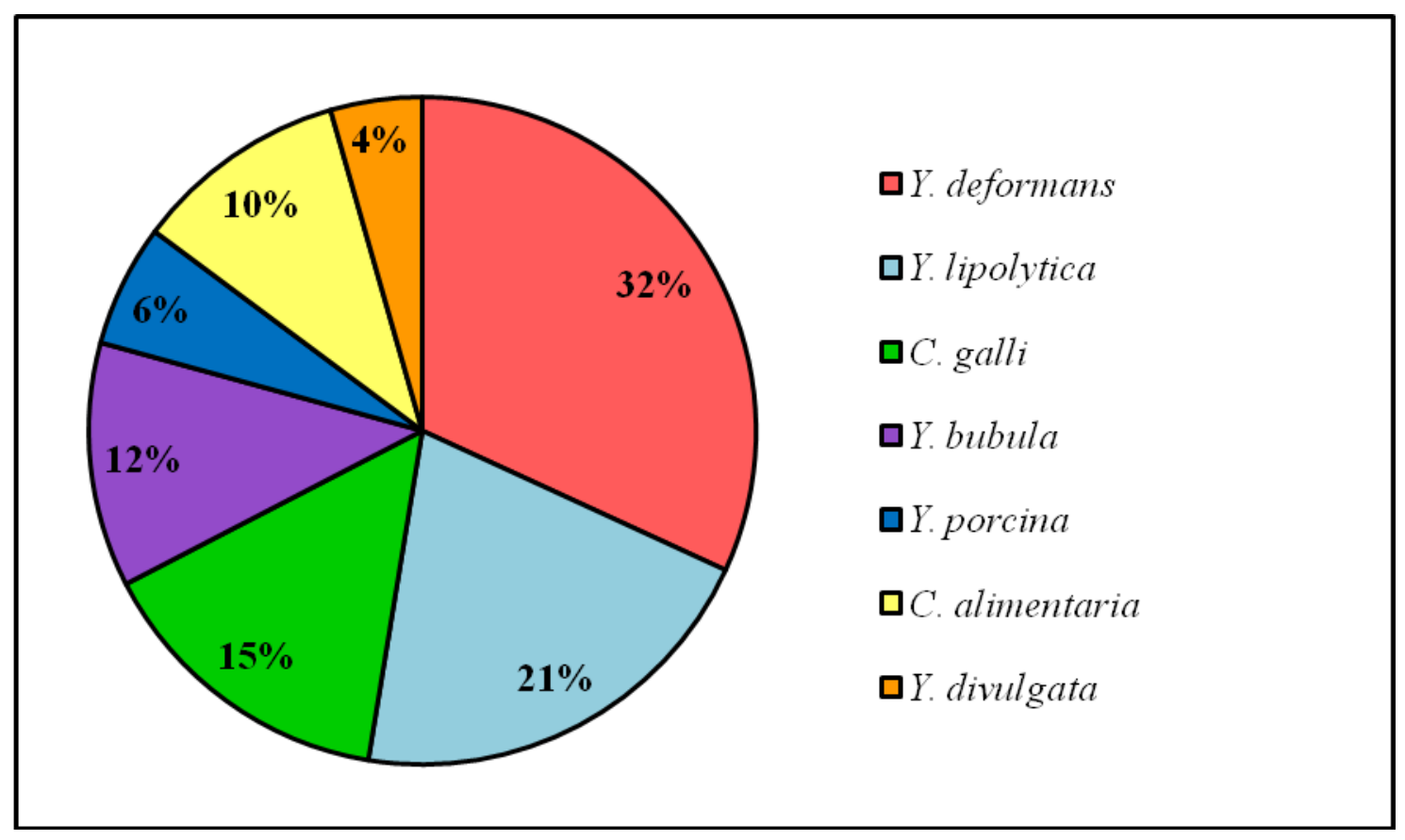

33. ábra. A nyers húsból izolált Yarrowia csoportba tartozó törzsek megoszlása (135 törzs 66 mintából) 
A nyers húsból izolált élesztőgombatörzsek sokféleségével ellentétben a nyers tejből és tejtermékekböl izolált, Yarrowia csoportba tartozó élesztőgombatörzsek csak két csoportot alkotnak, egy törzs kivételével ( $C$. alimentaria) mindegyik a Yarrowia lipolytica fajhoz tartozik (34. ábra).

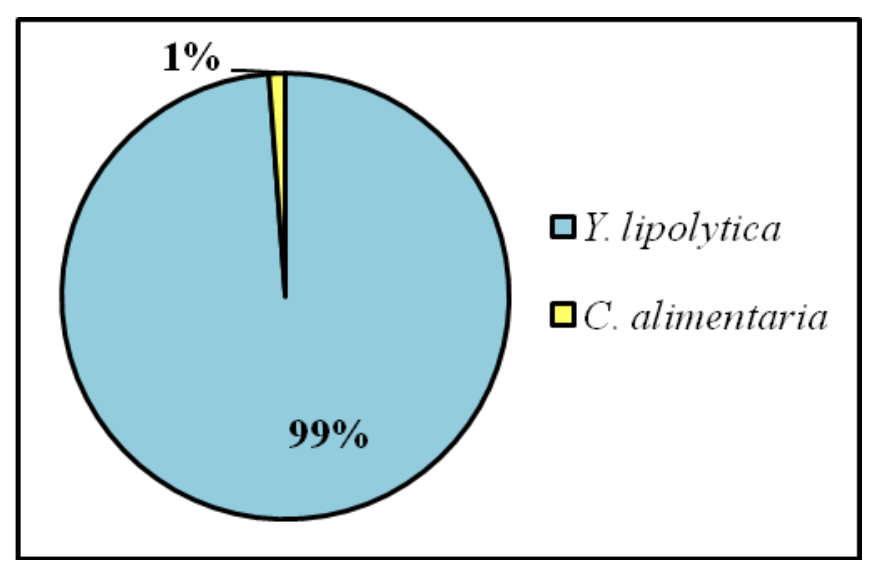

34. ábra. A tejből és tejtermékekből Yarrowia csoporthoz tartozó törzsek megoszlása (84 törzs 67 mintából)

Az összes élelmiszerből izolált Yarrowia csoportba tartozó törzs 51\%-a Y. lipolytica (111 törzs), 19\%-a Y. deformans (43 törzs), 9\%-a C. galli (20 törzs), 7\%-a C. alimentaria (15 törzs), a maradék 14\% pedig a közelmúltban leírt (Nagy et al. 2013, 2014) három új fajhoz tartozik (7\% $Y$. bubula (16 törzs), 4\% Y. porcina (8 törzs), 3\% Y. divulgata (6 törzs)) (35. ábra).

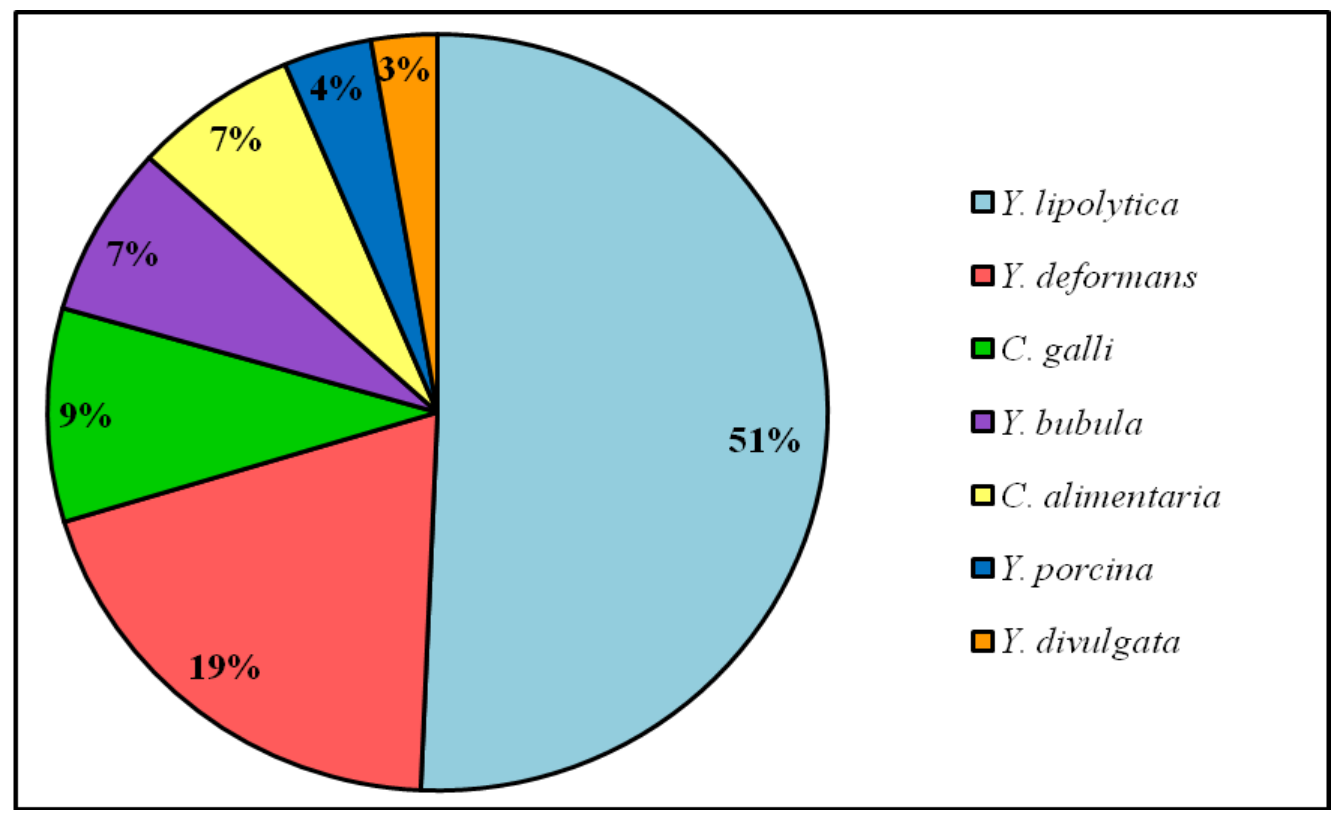

35. ábra. Az összes izolált Yarrowia csoportba tartozó törzs megoszlása (219 törzs 133 mintából) 


\subsection{Határozó kulcs a Yarrowia csoport tagjainak egymástól való elkülönítéséhez}

A Yarrowia csoport tulajdonságainak összehasonlítása után megállapítható, hogy fenotípusos tulajdonságaik alapján nem minden faj különíthető el egymástól. A $Y$. lipolytica, $Y$. keelungensis, $Y$. deformans, $Y$. porcina és $Y$. divulgata egy sztenderd fenotípusos tesztek alapján megkülönböztethetetlen komplex csoportot alkot. Az alábbiakban egy, a korlátozott fenotípusos elkülönítési lehetőségeket tükröző (dichotonikus) határozókulcsot ismertetek. Bár a Yarrowia csoport fajainak egy része a jelenleg rendelkezésre álló adatok alapján fenotípusos bélyegek alapján is elválasztható egymástól, a még fel nem fedett potenciális fajon belüli fenotípusos variabilitás és a csoportba tartozó leíratlan fajok miatt célszerü a Yarrowia csoport fajait D1/D2 és ha szükséges ITS szekvenciáik alapján azonosítani.

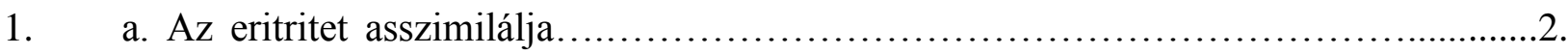

b. Az eritritet nem asszimilálja........................................ hispaniensis

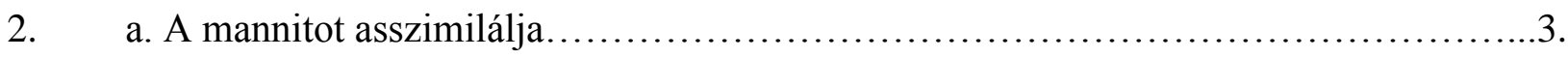

b. A mannitot nem asszimilálja...................................... oslonensis

3. a. Az etilamint képes asszimilálni...................................................

b. Az etilamint nem képes asszimilálni................................... hollandica

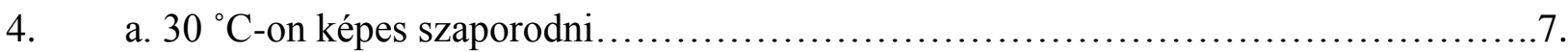

b. $30{ }^{\circ} \mathrm{C}$-on nem képes szaporodni........................................... 5.

5. a. A ribózt és NAG-t asszimilálja................................................

b. A ribózt és NAG-t nem asszimilálja................................. yakushimensis

6. a. A ribitet asszimilálja................................................ bubula

b. A ribitet nem asszimilálja............................................. alimentaria

7. b. Képes vitaminmentes táplevesben szaporodni................................... galli

a. Nem képes vitaminmentes táplevesben szaporodni ..............................

8. a. Az NAG-t nem asszimilálja..................................... phangngensis

b. Az NAG-t asszimilálja............................................ . deformans

Y. divulgata

Y. keelungensis

Y. lipolytica

Y. porcina 


\subsection{A Yarrowia csoport tagjainak az élelmiszerek romlásához esetlegesen hozzájáruló \\ tulajdonságai}

Teszteltem az összes Yarrowia csoportba tartozó törzs szakirodalom által említett, romláshoz potenciálisan hozzájáruló képességét, vagyis pigmentképző-, fehérjebontó- és zsírbontó-képességét. Az általam izolált Yarrowia csoportba tartozó törzseken kívül a típustörzseket és a MIMNG rendelkezésére álló, Yarrowia csoportba tartozó törzseket is vizsgáltam, összesen 273 törzset. Az eredményeket az alábbiakban részletezem.

\subsubsection{Pigmentképzés}

A Carreira és Loureiro (1998) által a Y. lipolytica elkülönítéséhez ajánlott tirozintartalmú táptalajon vizsgált pigmenttermelö-képesség értékelését 24 óra inkubációs idő után végeztem, a kinőtt telepek körül megjelenő barna elszíneződés jelezte a törzs pigmentképző-képességét. A különböző törzsek különböző mértékben voltak képesek pigment-termelésre, de az egy fajhoz tartozó törzsek néhány kivételtől eltekintve többé-kevésbé hasonló mennyiségü pigmentet képeztek.

Negatív kontrolként S. cerevisiae NCAIM Y.00801 ${ }^{\mathrm{T}}$ törzset használtam (36. ábra). A típustörzsek pigmenttermelő-képességét az alábbi ábrákon (37.-49. ábra) mutatom be.

36. ábra. Pigment termelő képesség vizsgálatához negatív kontrolként használt Saccharomyces cerevisiae NCAIM Y.00801 ${ }^{\mathrm{T}}$ törzs

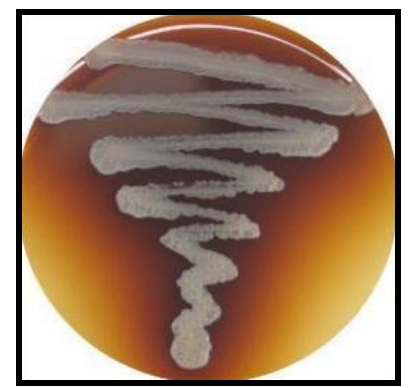

37. ábra. C. alimentaria $\mathrm{CBS} 10151^{\mathrm{T}}$ pigment termelése 


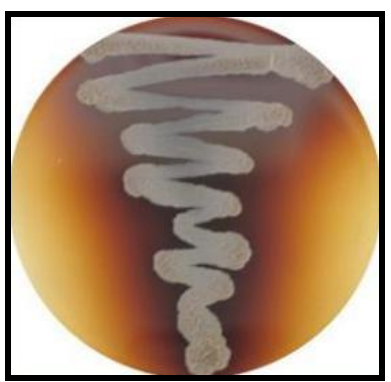

38. ábra.

C. galli

NCAIM Y. $1482^{\mathrm{T}}$

pigment termelése

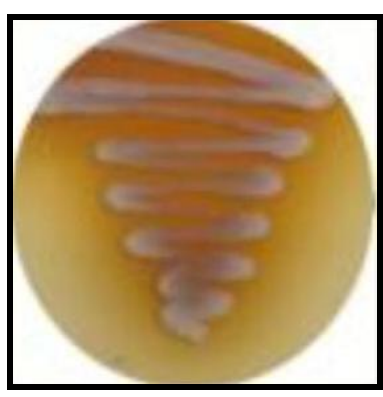

42. ábra.

C. phangngensis

CBS $10407^{\mathrm{T}}$ pigment termelése

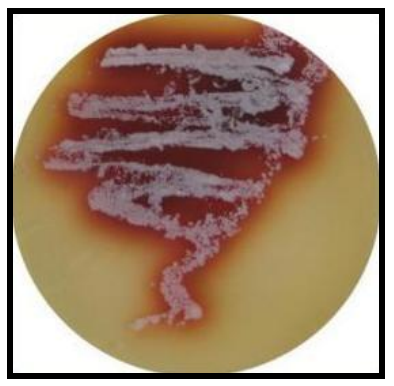

46. ábra.

$Y$. keelungensis

CBS $11062^{\mathrm{T}}$ pigment termelése

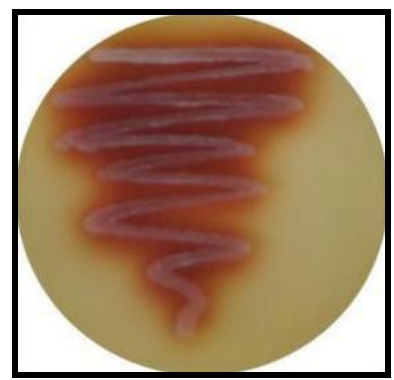

39. ábra.

C. hispaniensis

NRRL4-5580 ${ }^{\mathrm{T}}$

pigment termelése

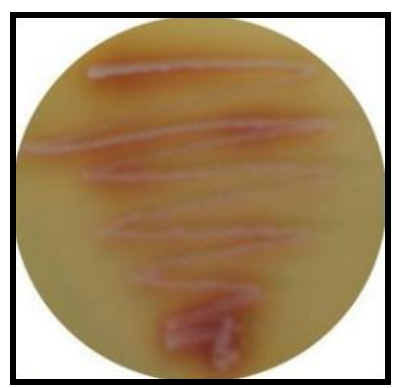

43. ábra.

Y. bubula

NCAIM Y.01998 ${ }^{\mathrm{T}}$

pigment termelése

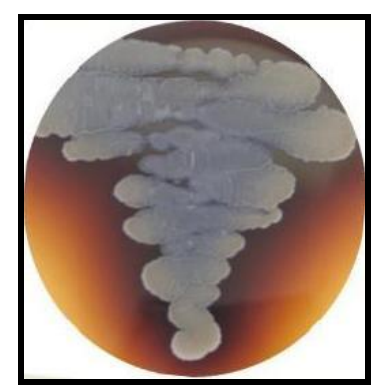

47. ábra.

$Y$. lipolytica

NCAIM Y.0591 ${ }^{\mathrm{T}}$

pigment termelése

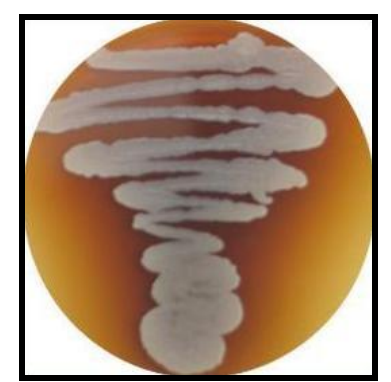

40. ábra.

C. hollandica

CBS $4855^{\mathrm{T}}$ pigment termelése

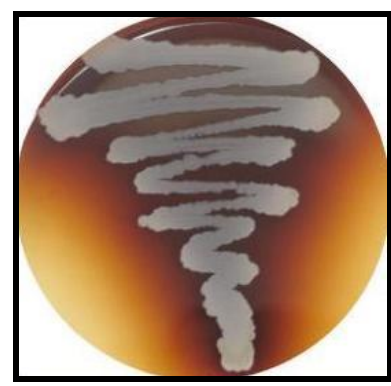

44. ábra.

$Y$. deformans

NCAIM Y.02005

pigment termelése

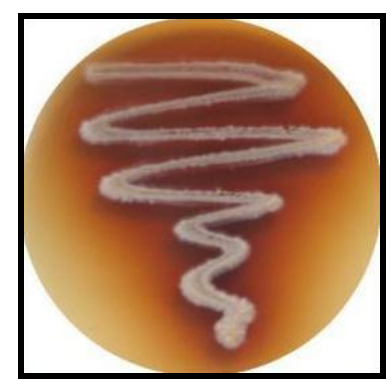

48. ábra.

$Y$. porcina

NCAIM Y.02100 ${ }^{\mathrm{T}}$

pigment termelése

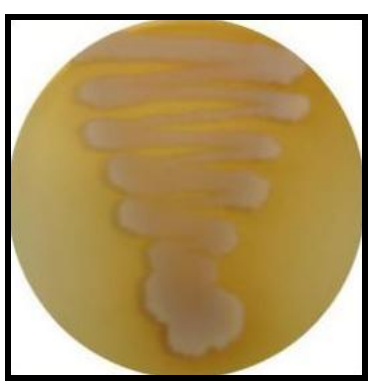

41. ábra.

C. oslonensis

CBS $10146^{\mathrm{T}}$ pigment termelése

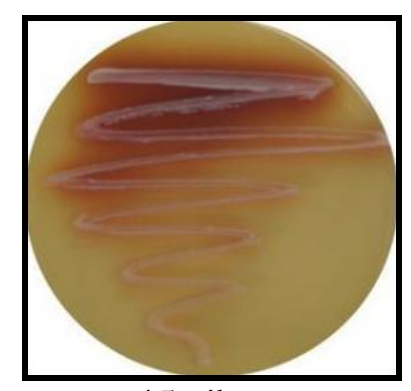

45. ábra.

Y. divulgata

F6- $17^{\mathrm{T}}$ pigment

termelése

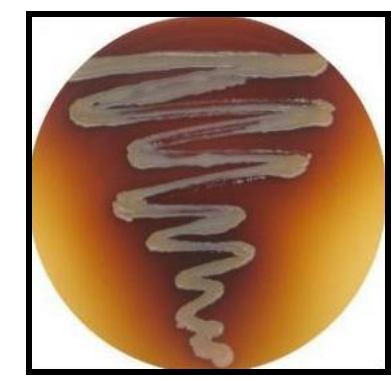

49.ábra.

Y. yakushimensis

JCM $12782^{\mathrm{T}}$ pigment

termelése

A C. oslonensis típustörzse (CBS $10146^{\mathrm{T}}$ ), a faj egyetlen ismert törzse, a C. galli NCAIM Y.01483 törzse és kettő általam izolált $Y$. lipolytica és egy $Y$. deformans törzs nem képes pigment-termelésre tirozintartalmú táptalajon.

A kapott eredmények alátámasztják azt a feltételezést, hogy a táptalaj nem alkalmas a $Y$. lipolytica szelektív izolálására, és a pigment-képzésre nem képes, de a Yarrowia csoportba tartozó néhány törzs miatt a csoport többi élesztőgombától való megkülönböztetésére való alkalmazhatósága is bizonytalan. Az említett néhány törzs kivételével a Yarrowia csoport tagjai tirozintartalmú táptalajon kisebb-nagyobb mértékű elszíneződést képesek okozni, ezáltal potenciálisan jelentős gazdasági veszteséget képesek okozni a sajtgyártás során. 


\subsubsection{Lipolitikus aktivitás}

A lipolitikus aktivitást olívaolajat tartalmazó agarlemezre való szélesztéssel teszteltem. $25{ }^{\circ} \mathrm{C}$-on történő, 10 napos inkubációt követően a lemezeket 1 percre elárasztottam telített rézszulfát oldattal, majd leolvastam az eredményt. Pozitív eredményt, lipolitikus aktivitást a telepek kék elszíneződése jelezte (Marquina et al. 1992).

Negatív kontrolként S. cerevisiae NCAIM Y.00801 ${ }^{\mathrm{T}}$ törzset használtam. Ebben az esetben nemcsak hogy nem volt tapasztalható kék elszíneződés, de a telep annyira gyengén nőtt ki, hogy a képen alig látható (50. ábra)

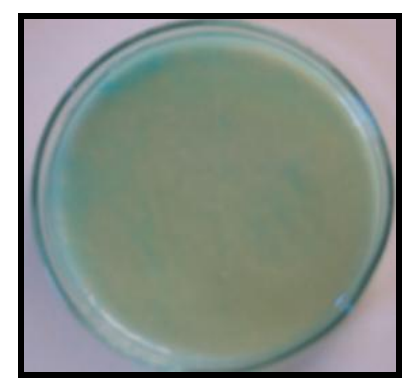

50. ábra. A zsírbontó képesség vizsgálatához negatív kontrolként használt S. cerevisiae NCAIM Y.00801 ${ }^{\mathrm{T}}$ törzs

A Yarrowia csoport fajai típustörzseinek zsírbontó képességét az alábbi ábrákon (51.-63. ábra) mutatom be.

A Y. yakushimensis törzsek közül az NCAIM Y.02049 nagyon gyenge lipolitikus aktivitással rendelkezik, a többi (JCM12782 ${ }^{\mathrm{T}}$, NCAIM Y.02052, NCAIM Y.02050) nem bontja a zsírt.

A többi fajhoz tartozó törzs szinte kivétel nélkül erős lipolitikus aktivitással rendelkezik.

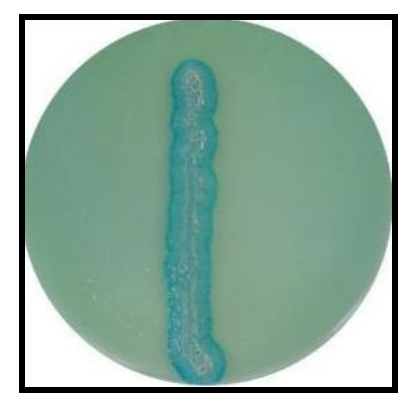

51. ábra. C. alimentaria $\mathrm{CBS} 10151^{\mathrm{T}}$ zsírbontó képességének mértékét jelző kék elszíneződés 


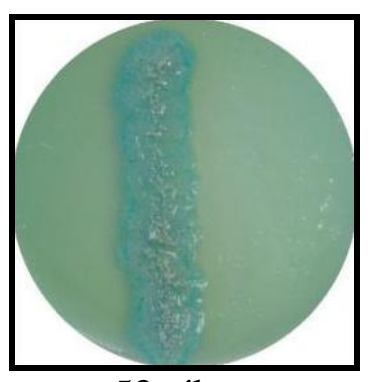

52. ábra.

C. galli

NCAIM Y. 01482 ${ }^{\mathrm{T}} \quad$ NRRL4-5580 ${ }^{\mathrm{T}}$

zsírbontó képességének zsírbontó képességének mértékét jelző kék elszíneződés

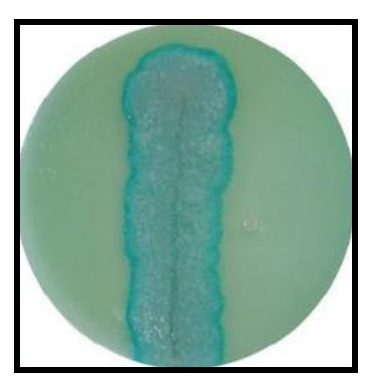

56. ábra.

C. phangngensis CBS $10407^{\mathrm{T}}$

zsírbontó

képességének mértékét jelző kék elszíneződés

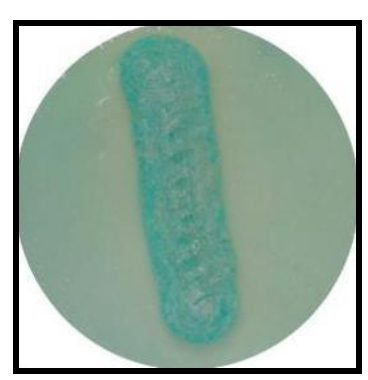

60. ábra.

$Y$. keelungensis CBS $11062^{\mathrm{T}}$ zsírbontó képességének mértékét jelző kék elszíneződés

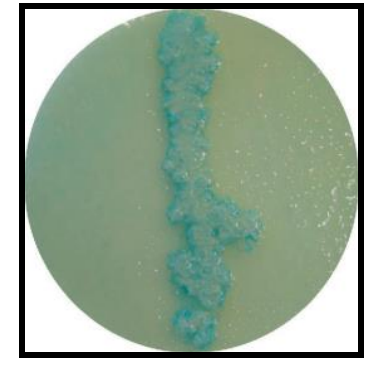

57. ábra.

Y. bubula

NCAIM Y.01998 zsírbontó

képességének mértékét jelző kék elszíneződés

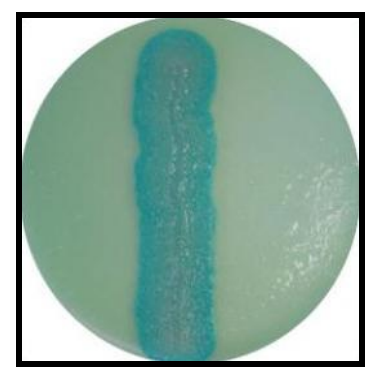

61. ábra.

Y. lipolytica NCAIM Y.00591 ${ }^{\mathrm{T}}$ zsírbontó

képességének mértékét jelző kék elszíneződés

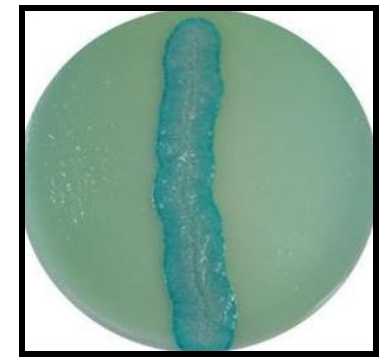

58. ábra.

$Y$. deformans

NCAIM Y.02005 ${ }^{\mathrm{T}}$ zsírbontó képességének mértékét jelző kék elszíneződés

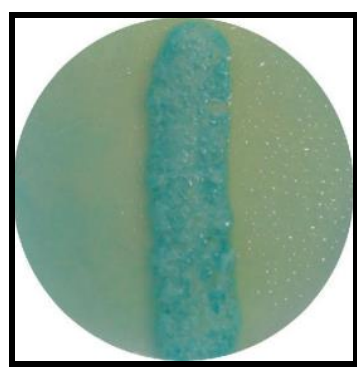

62. ábra.

$Y$. porcina NCAIM Y.02100 zsírbontó képességének mértékét jelző kék elszíneződés

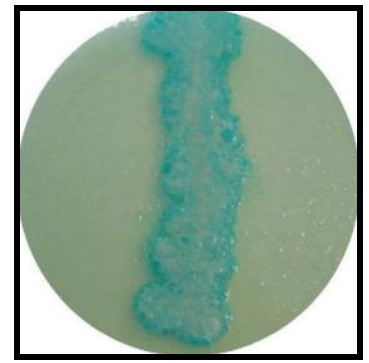

59. ábra.

Y. divulgata F6-17 ${ }^{\mathrm{T}}$ zsírbontó képességének mértékét jelző kék elszíneződés

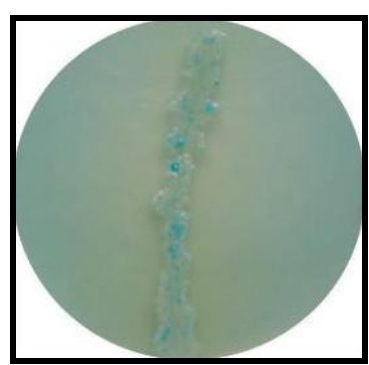

63.ábra.

Y. yakushimensis JCM $12782^{\mathrm{T}}$ zsírbontó képességének mértékét jelző kék elszíneződés 


\subsubsection{Proteolitikus aktivitás}

A törzsek fehérjebontó-képességét zselatin-hidrolízis tesztelése által mértem fel. A zselatint tartalmazó kémcsöveket $0,1 \mathrm{ml}, 2+$,'-es sejtszuszpenzióval történő beoltás után $25{ }^{\circ} \mathrm{C}$ on inkubáltam 3 hétig. A leolvasást hetente végeztem, leolvasás előtt 1 órára hűtőszekrénybe helyeztem a kémcsöveket. A proteolitikus aktivitást az elfolyósodott (hütőszekrényben is folyékony) zselatin jelezte. A 12. táblázatban a Yarrowia csoportba tartozó fajok típustörzseinek fehérjebontó-képességét mutatom be.

12. táblázat. A Yarrowia csoport típustörzseinek fehérjebontó-képessége

\begin{tabular}{|c|c|c|c|c|}
\hline \multirow[b]{2}{*}{ Faj } & \multirow[b]{2}{*}{ Törzs kódja } & \multicolumn{3}{|c|}{ Zselatin-elfolyósítás } \\
\hline & & 7 nap & 14 nap & 21 nap \\
\hline C. alimentaria & CBS $10151 \mathrm{~T}$ & + & & \\
\hline C. galli & NCAIM Y.01482 T & + & & \\
\hline C. hispaniensis & NRRL4-5580 T & - & - & - \\
\hline C. hollandica & CBS4855 T & + & & \\
\hline C. oslonensis & CBS10146 T & + & & \\
\hline C. phangngensis & CBS10407 T & - & - & - \\
\hline Y. bubula & NCAIM Y.01998 T & + & & \\
\hline Y. deformans & NCAIM Y.02005 T & + & & \\
\hline Y. divulgata & F6-17 T & + & & \\
\hline Y. keelungensis & CBS11062 T & - & i.gy. & gy. \\
\hline$Y$. lipolytica & NCAIM Y.0591 T & + & & \\
\hline Y. porcina & NCAIM Y.0859/5 T & gy. & + & \\
\hline Y. yakushimensis & JCM12782 T & + & & \\
\hline
\end{tabular}

T: típustörzs;

NCAIM: Mezőgazdasági és Ipari Mikroorganizmusok Nemzeti Gyűjteménye (National Collection of Agricultural and Industrial Microorganisms), Budapest, Magyarország; CBS: Centraalbureau voor Schimmelcultures, Utrecht, Hollandia;

NRRL: Culture Collection, National Center for Agricultural Utilization Research, Peoria, IL USA;

JCM: Japan Collection of Microorganisms, Tsukuba, Japán 
A $C$. hispaniensis és a $C$. phangngensis típustörzsek nem képesek a zselatin elfolyósítására, a $Y$. keelungensis típustörzse pedig csak lassan bontja azt. A többi fajhoz tartozó legtöbb törzs már egy héten belül teljesen elfolyósította a zselatint, kisebb hányaduk az első leolvasáskor (7. nap) csak részben, majd teljesen csak a második leolvasáskor (14. nap).

A fejezetben ismertetett eredményekből megállapítható, hogy az összes vizsgált Yarrowia csoportba tartozó törzs rendelkezik legalább egy romlást-okozó képességgel, de többségük több módon is veszélyt jelenthet az élelmiszerek minőségére. Ez összhangban van a szakirodalomban említett tapasztalatokkal, mely szerint a Y. lipolytica (és a Yarrowia csoport tagjai) igen fontos szerepet játszanak az élelmiszerek romlásában.

\subsection{A Yarrowia csoport tagjainak sporulációja}

A Yarrowia csoportba tartozó fajok közül sokáig csak egyetlen fajnak, a Y. lipolytica-nak ismerték a teleomorf (ivaros) alakját. 2013-ban számoltak be a C. deformans teleomorf alakjáról, átsorolva a fajt a Yarrowia nemzetségbe (Groenewald és Smith 2013). A három fentebb ismertetett új fajt alkotó törzsek fajon belüli párosodási készségét vizsgálva azt tapasztaltam, hogy a $Y$. porcina fajba tartozó törzsek közül néhány képes egymással párosodni és aszkospórákat képezni, így háromra növekedett a Yarrowia csoport ismert ivaros alakkal rendelkező fajainak száma (29. ábra). A Y. porcina a nemzetség eddigi egyetlen ismert faja, amelynek aszkospórái tokanyagba ágyazódnak (29. és 64. ábra). Ez a tulajdonság az összes élesztőgomba között is igen ritka.

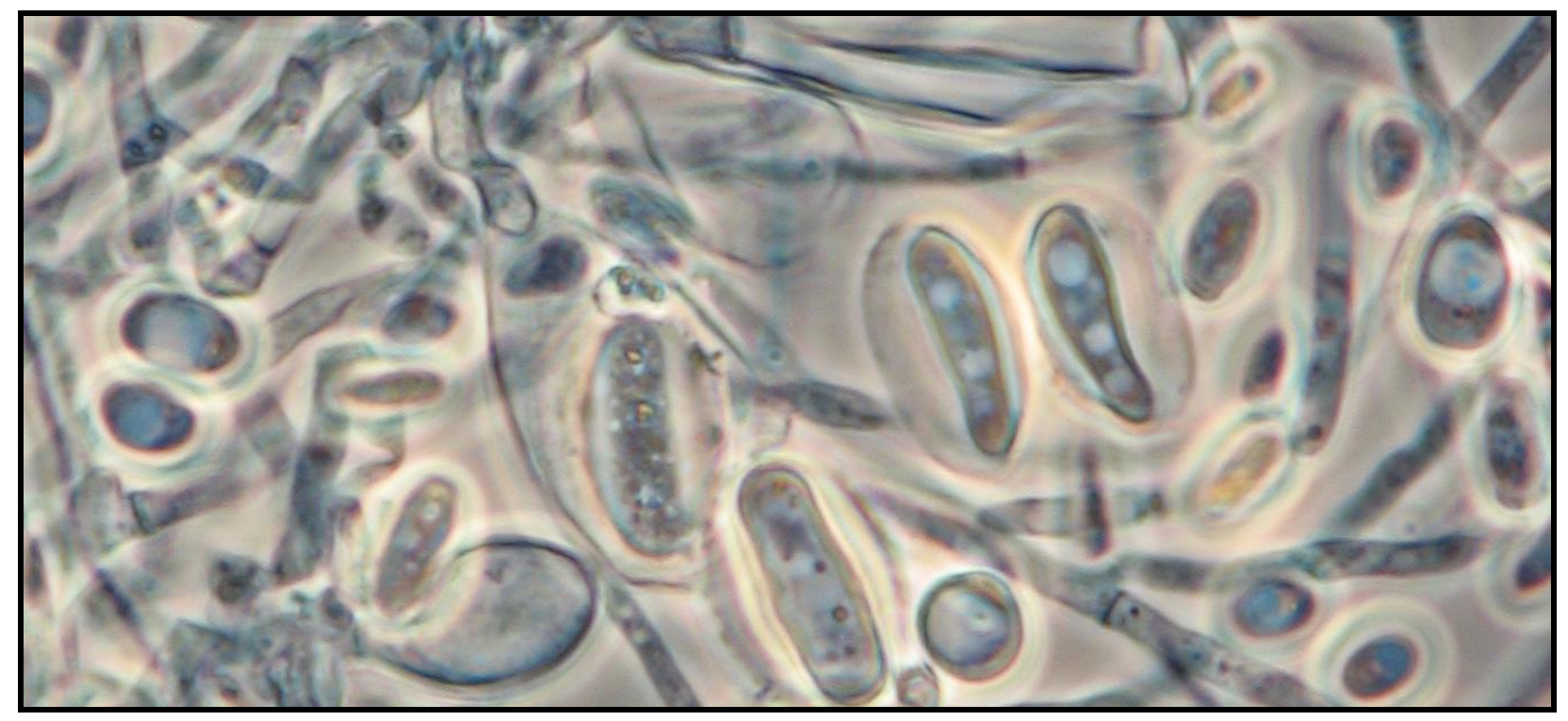

64. ábra. A Y. porcina tokanyagba ágyazott aszkospórái szabadon és aszkuszban. Fáziskontraszt mikroszkópos felvétel. 
A spóráztatáshoz használt kevert tenyészeteket megöriztem, és több mint három hónap elteltével nem csak sporangiumban lévő és kiszabadult spórákat találtam, hanem azok csírázását is sikerült megfigyelnem és lefényképeznem (65. ábra).

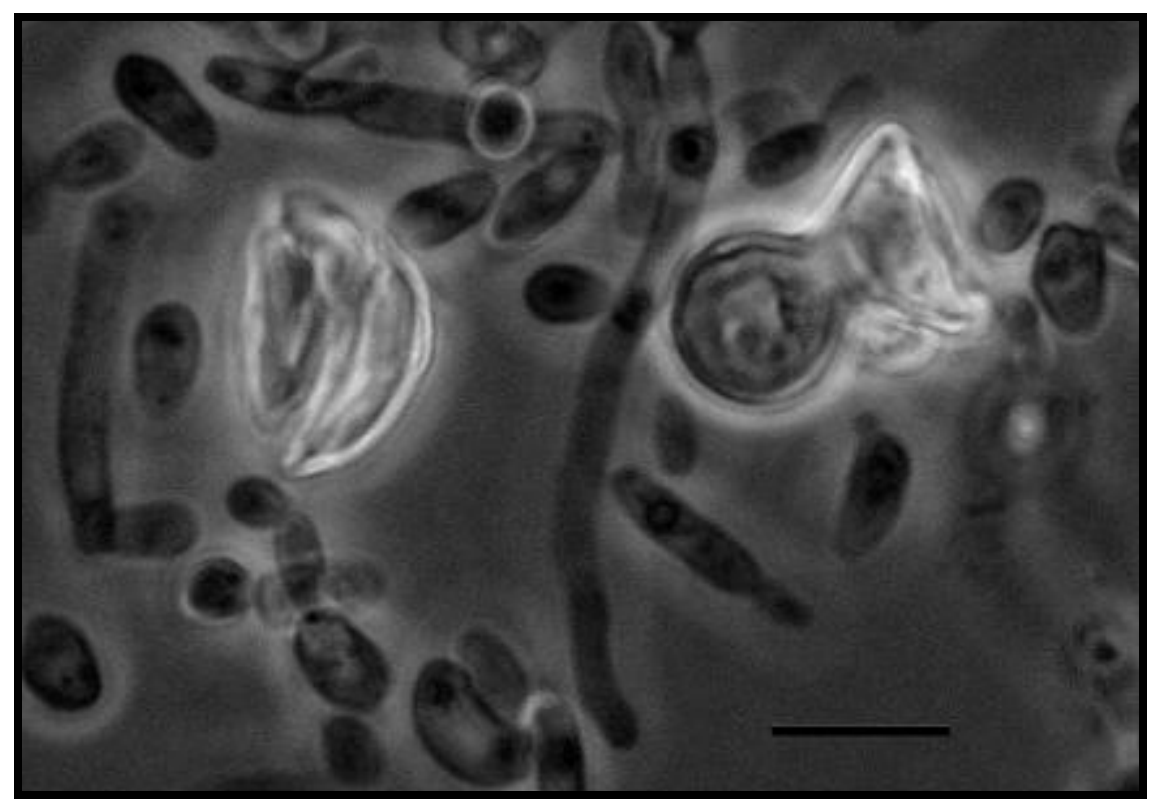

65. ábra. Az NCAIM Y.02100 és UFMG-RD131 ${ }^{\mathrm{A}}$ Yarrowia porcina törzsek csírázó aszkospórja YES agaron, $25^{\circ} \mathrm{C}$-on, 143 nap után. Lépték $10 \mu \mathrm{m}$. Fáziskontraszt mikroszkópos felvétel. Forrás: Nagy et al. 2014.

A Yarrowia csoport korábban ismert fajaihoz tartozó (régebb óta a MIMNG törzsgyüjteményben lévő és az általam újonnan izolált) törzsek fajon belüli párosodási készségét is vizsgáltam, de egyik esetben sem tapasztaltam spóraképződést. 


\subsection{Az izolált, nem a Yarrowia csoportba sorolt, hexadekán-asszimiláló törzsek fajszintü azonosítása}

A leírt élesztőgombafajok csak kis hányadáról ismert, hogy képes a hexadekán asszimilációjára. Emiatt nagyon érdekesnek és értékesnek tartom azt az információt, hogy a vizsgálataim során izolált, nem a Yarrowia csoportba tartozó hexadekán-pozitív törzsek milyen fajokhoz tartoznak. Részben emiatt, részben pedig további új fajokhoz tartozó törzsek felismerésének reményében vizsgáltam azokat az általam izolált hexadekán-pozitív törzseket (175 törzs), melyeket fiziológiai tulajdonságaik alapján nem soroltam a Yarrowia csoportba.

A Yarrowia csoport tagjaival megegyező módon MP-PCR felhasználásával felszaporított DNS fragmentek gélelektroforézisével nyert mintázatuk alapján csoportosítva, majd D1/D2 DNS szekvenciájuk alapján azonosítva őket meghatároztam, hogy milyen arányban oszlanak meg ezek a fajok a vizsgált élelmiszerekben.

A hexadekán-pozitív de a Yarrowia csoportba nem tartozó élesztőgomba törzsek jóval nagyobb diverzitást mutattak az élelmiszerekben, mint a Yarrowia csoport tagjai. Azonosításuk során a legtöbb esetben a Yarrowia csoport tagjaihoz hasonlóan azt tapasztaltam, hogy a kiválasztott törzsek szekvenciáinak a GenBank adatbázisban található szekvenciákkal való összehasonlítása alapján történt azonosítás eredménye megegyezett a törzsek MP-PCR segítségével megsokszorozott DNS fragmentek gélelektroforézissel kapott mintázata alapján történt feltételes azonosítással. Ezeknek a törzseknek a vizsgálata során azonban nem minden esetben tudtam előre megbecsülni a faji hovatartozást a DNS fragmentek gélelektroforézissel kapott mintázata alapján. A Yarrowia csoport tagjainál tapasztaltakkal ellentétben több esetben tapasztaltam, hogy eltérő MP-PCR mintázatot adó törzsek ugyanannak a fajnak a tagjai. Ez összhangban van Ramírez-Castrillón 2014-ben megjelent tanulmányának következtetésével, mely szerint az élesztőgomba törzsek MP-PCR alapú csoportosítása nem teljes mértékben megbízható. Az egyes csoportok nem feltétlenül csak azonos fajhoz tartozó törzseket tartalmaznak és azonos fajhoz tartozó törzsek különböző csoportokba is kerülhetnek. Bár a módszer jól müködött az általam tesztelt Yarrowia csoportba tartozó törzsek esetében, úgy gondolom, hogy ha más élesztőgombákat vizsgálunk az említett módszerrel, csak kellő körültekintéssel szabad következtetéseket levonni, egyértelmü eredményt csak DNS szekvenciájuk vizsgálata alapján kaphatunk. 
A törzsek szekvencia analízise után kiderült, hogy a fiziológiai tesztek alapján egyetlen olyan törzset sem soroltam a Yarrowia csoportba, ami valójában nem tartozik oda, azonban ez fordítva nem igaz. Meglepő módon néhány törzsről kiderült, hogy a megismert fiziológiai tulajdonságaikra alapozott következtetéssel ellentétben mégis a Yarrowia csoport fajaihoz tartoznak (17 törzs).

Néhány törzset a glükózerjesztés tesztelése során a Durham-csőben megjelenő néhány buborék miatt tévesen pozitívnak véltem, emiatt nem soroltam a Yarrowia csoportba. A többi törzs többsége egy vagy néhány asszimilációs tulajdonsága kismértékben eltért a Yarrowia csoport tagjaira jellemző asszimilációs tulajdonságoktól. Kismértékü eltérés alatt azt értem, ha például bizonyos szénforrásokat a Yarrowia csoportba tartozó fajok jellemzően képesek asszimilálni, de a vizsgált törzs csak kismértékben szaporodott el a teszthez használt közegben, így nem lehetett egyértelmüen pozitívnak minősíteni. Néhány esetben előfordult, hogy egy adott szénforrás asszimilációjára a Yarrowia csoport tagjaira jellemzően negatív eredményt vártam, de pozitívat tapasztaltam. Ez okból nem sikerült a Yarrowia csoport tagjaként elkülöníteni azt a törzset, melyről később kiderült, hogy a negyedik új faj tagja, mivel az a Yarrowia csoport tagjaival ellentétben képes a raffinózt asszimilálni.

Ezek alapján arra a következtetésre jutottam, hogy a Yarrowia csoport tagjaira jellemző tulajdonságoktól csak kismértékü eltéréseket mutató törzseket érdemes lett volna nagyobb rugalmassággal, a csoport feltételes tagjaként kezelni.

A Yarrowia csoport tagjain kívül 22 hexadekán-asszimiláló faj képviseltette magát a vizsgált élelmiszerekben.

Többségükről ismert volt ez a képesség. A Clavispora lusitaniae és a Candida sake hexadekán asszimilálsó képessége a szakirodalom szerint változó, a $C$. pararugosa, C. zeylanoides és $C$. saitoana hexadekán-negatív fajokként vannak számon tartva, a C. tropicalis-ról pedig a monográfiában (Kurtzman et al. 2011) nincs erre vonatkozó információ. 


\subsection{Hexadekán-pozitív élesztőgombatörzsek megoszlása a vizsgált élelmiszerekben}

A 66-71. ábrákon azt mutatom be, hogyan oszlanak meg a hexadekán-pozitív törzsek (394 törzs). A 67. és 68. ábra összevetése alapján, nyers hús esetében a hexadekán-pozitív törzsek között jóval nagyobb a Yarrowia csoportba tartozók aránya (81\%) mint a tejtermékekből izoláltak esetében $(41 \%)$.

A 67., 69., 70. és 71. ábrákat összevetve megállapítható, hogy nyers tejben, túróban és sajtban egyaránt a Clavispora lusitaniae faj dominál és a $C$. intermedia a második legnagyobb számban izolált faj. Mindhárom említett termékben előfordul C. parapsilosis, Meyerozyma guilliermondii és $C$. butyri.

Clavispora lusitaniae-t, C. intermedia-t, C. parapsilosis-t és Meyerozyma guilliermondii-t húsokból is izoláltam. 


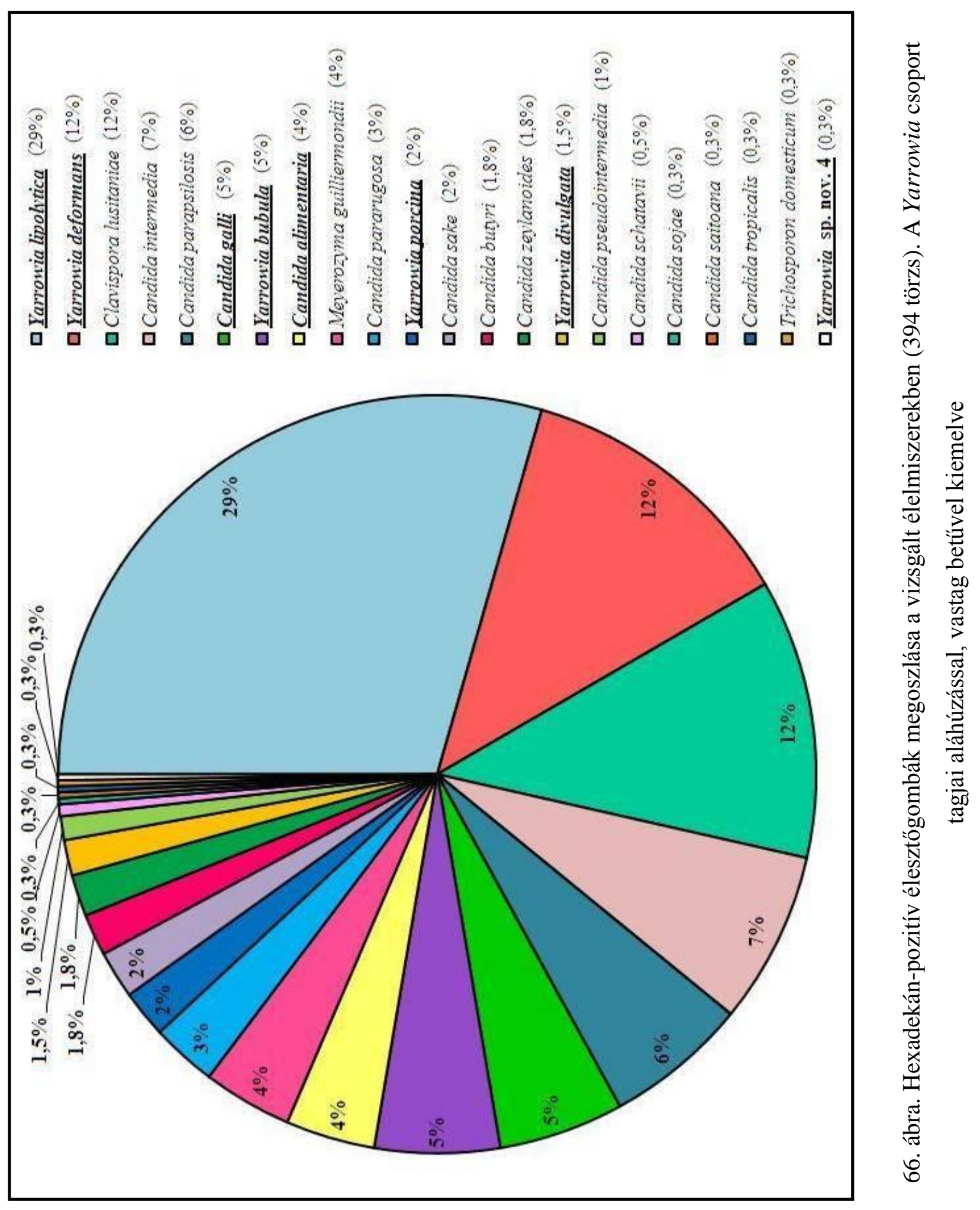



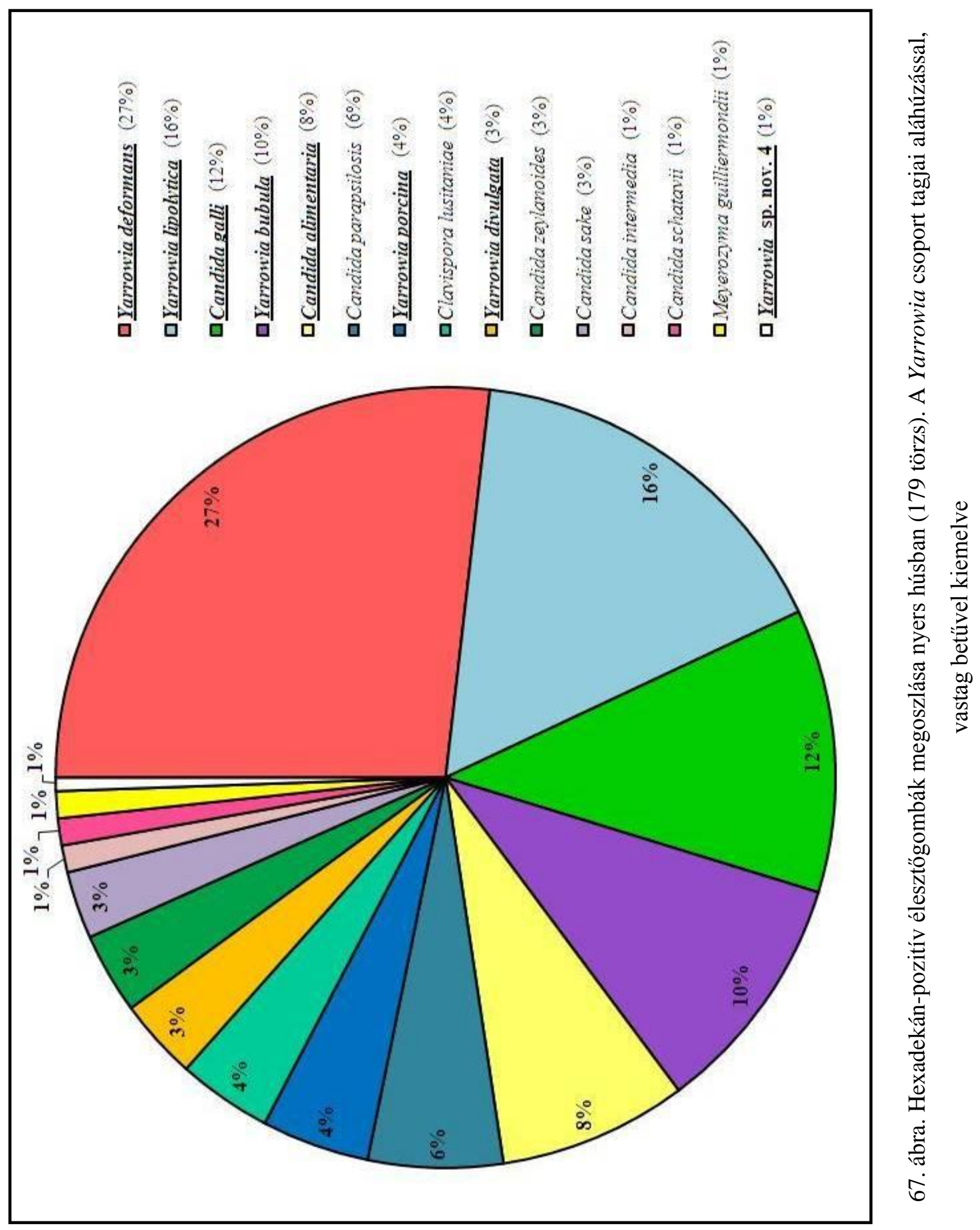

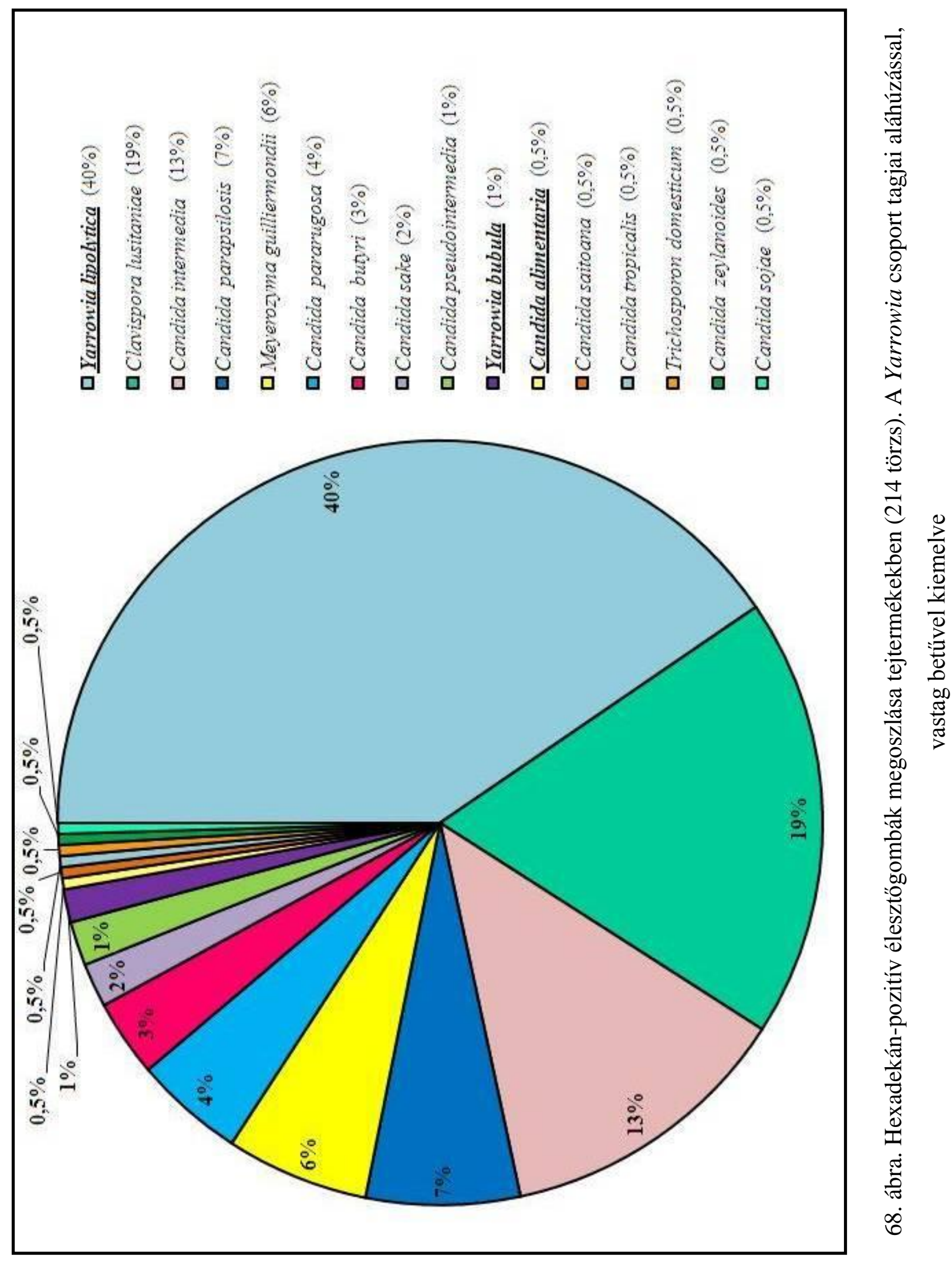


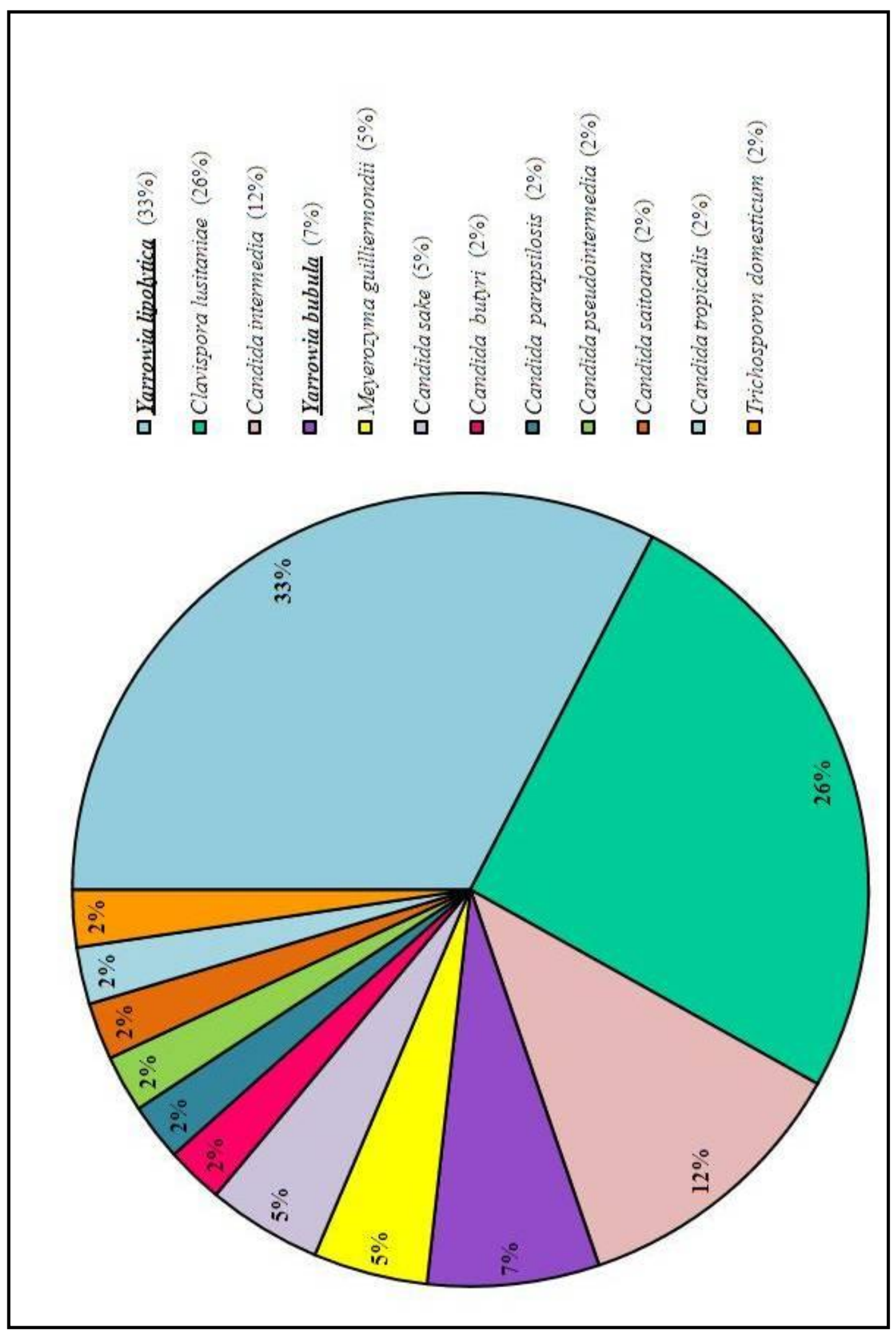

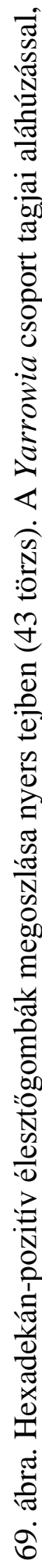




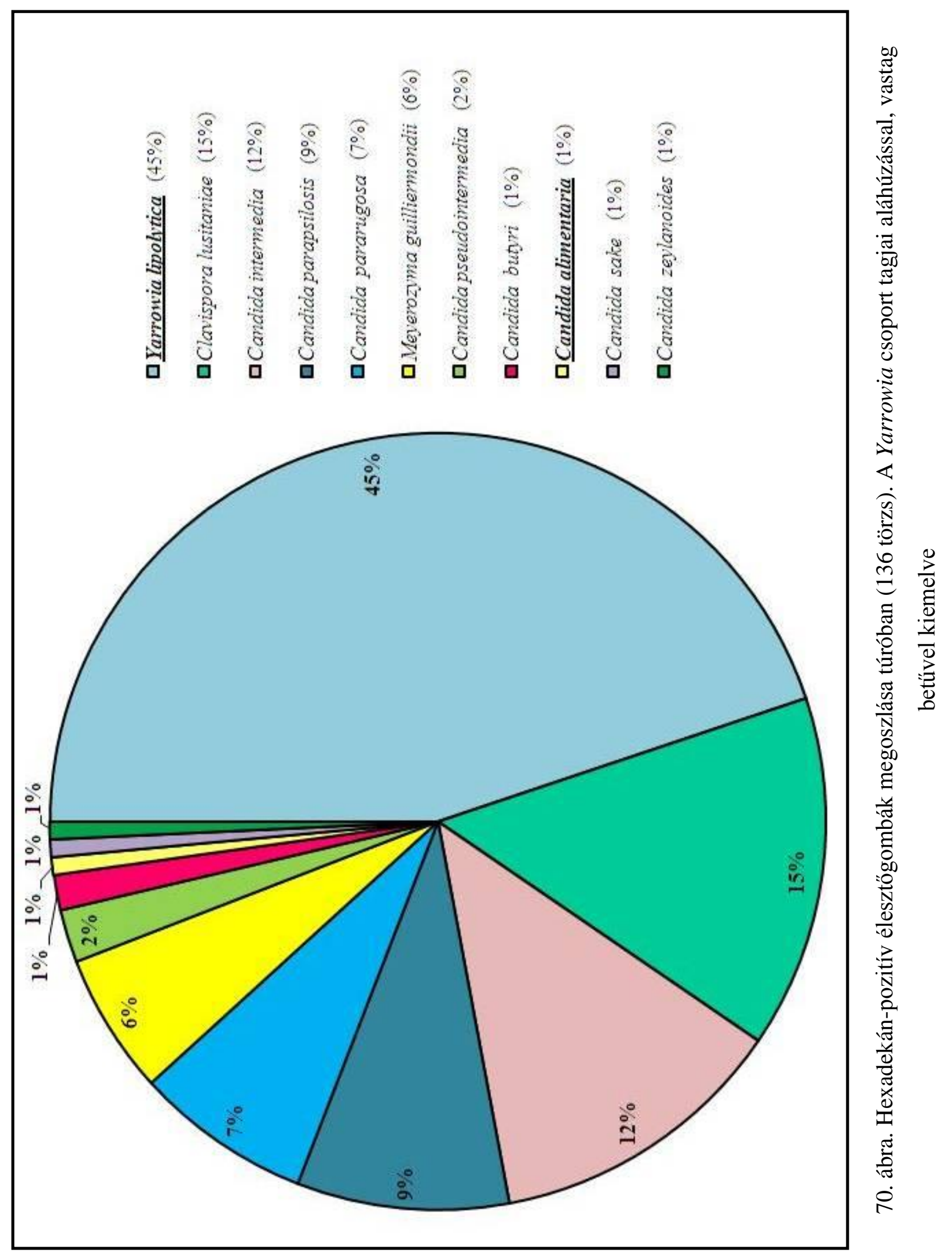



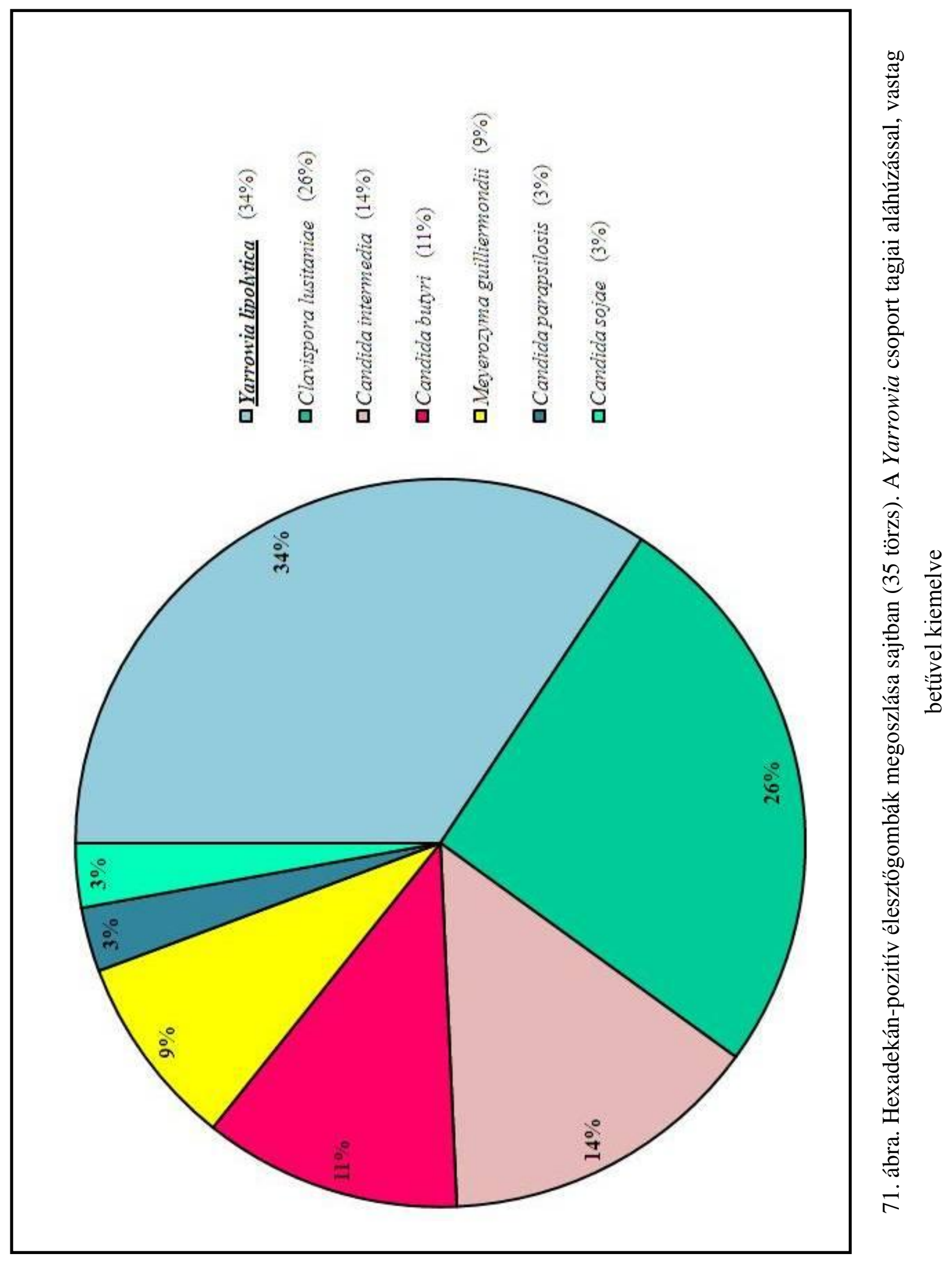
5.12. Az újonnan kidolgozott módszerrel izolált élesztőgombatörzsek megoszlása a vizsgált élelmiszerekben

A 72-77. ábrán azt mutatom be, hogyan oszlanak meg az általam izolált törzsek a vizsgált élelmiszerekben.
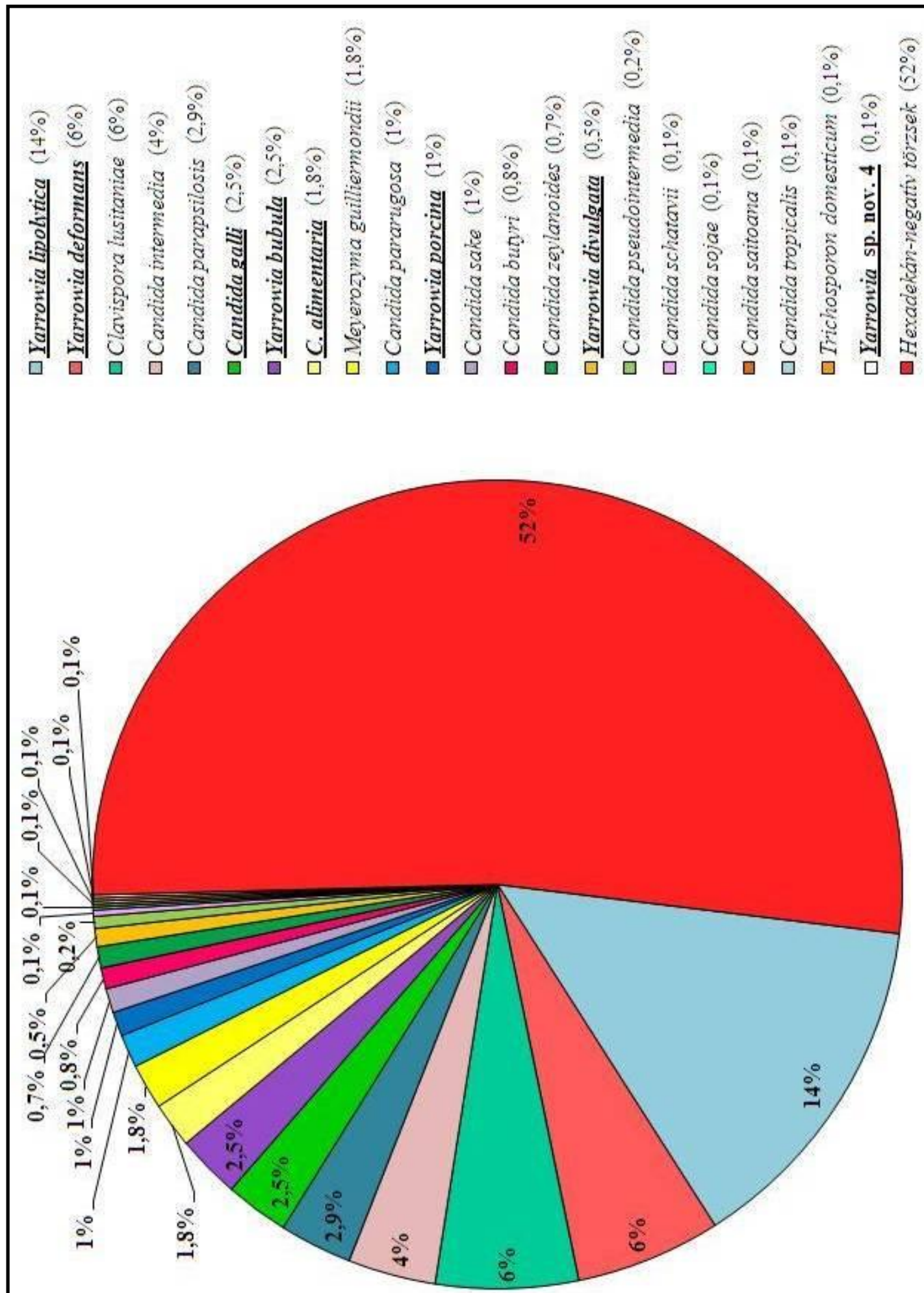

要 


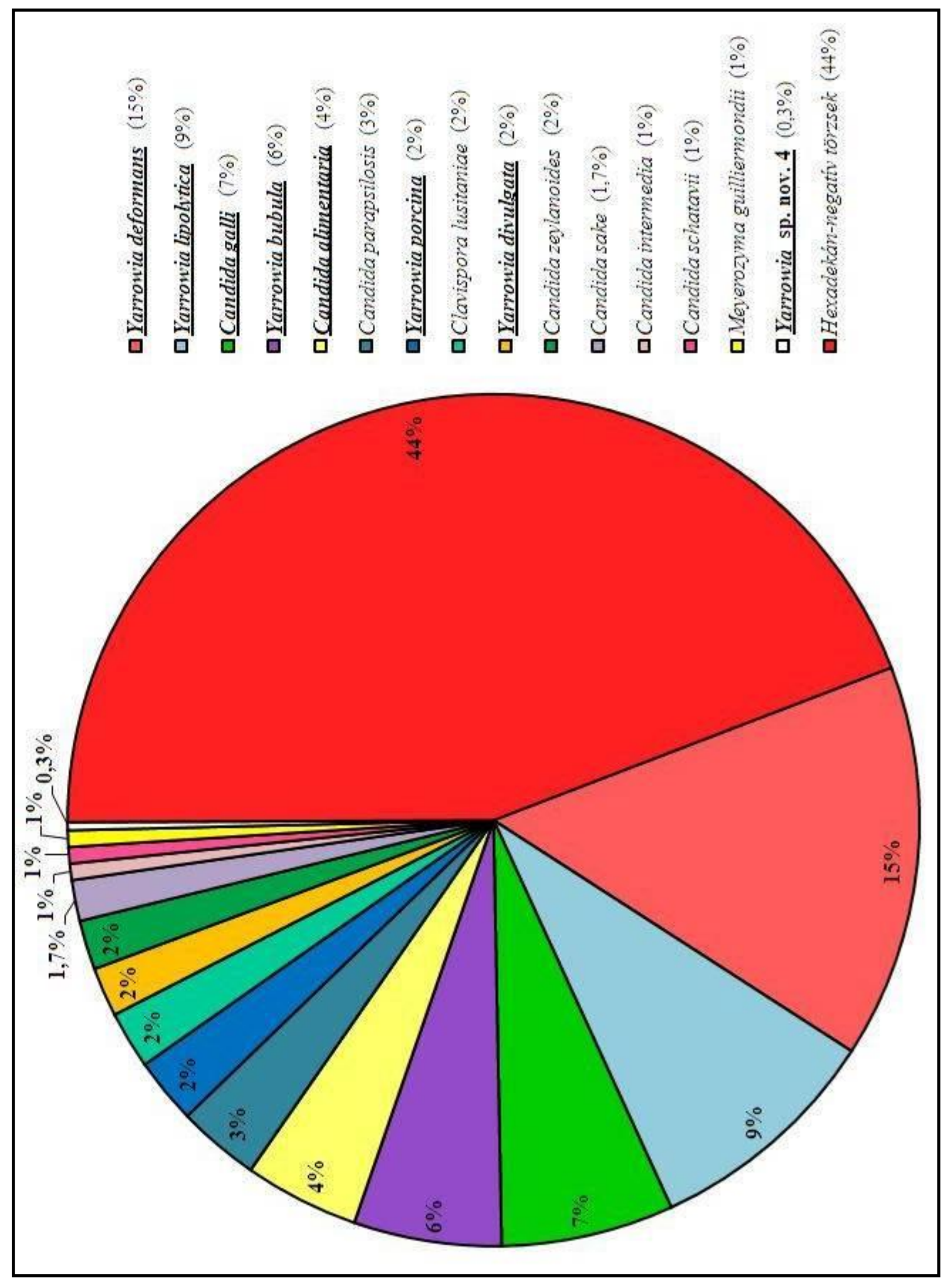

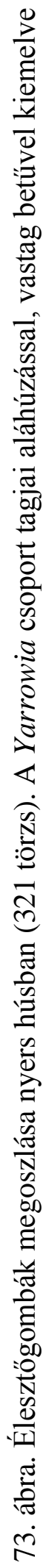



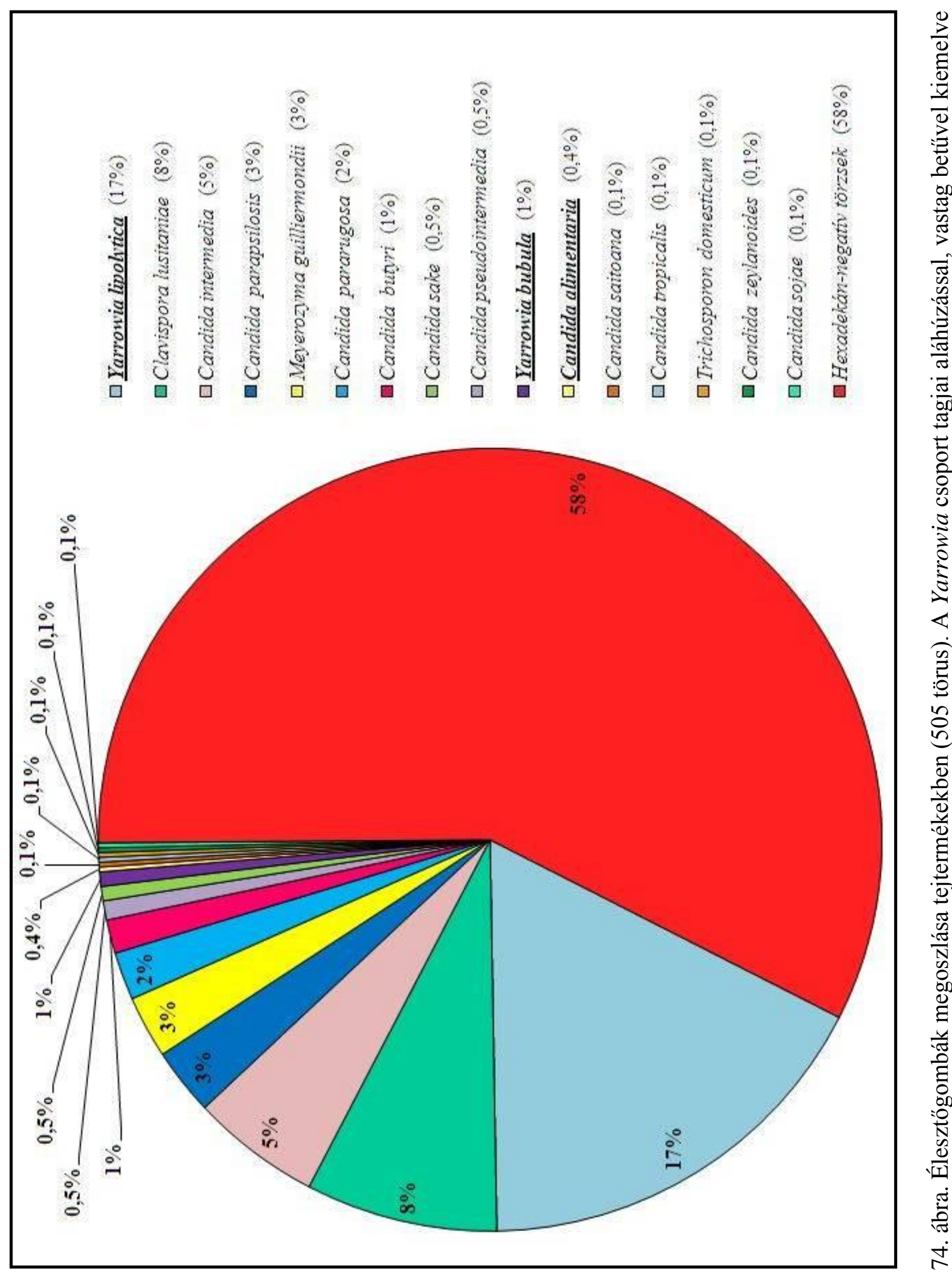


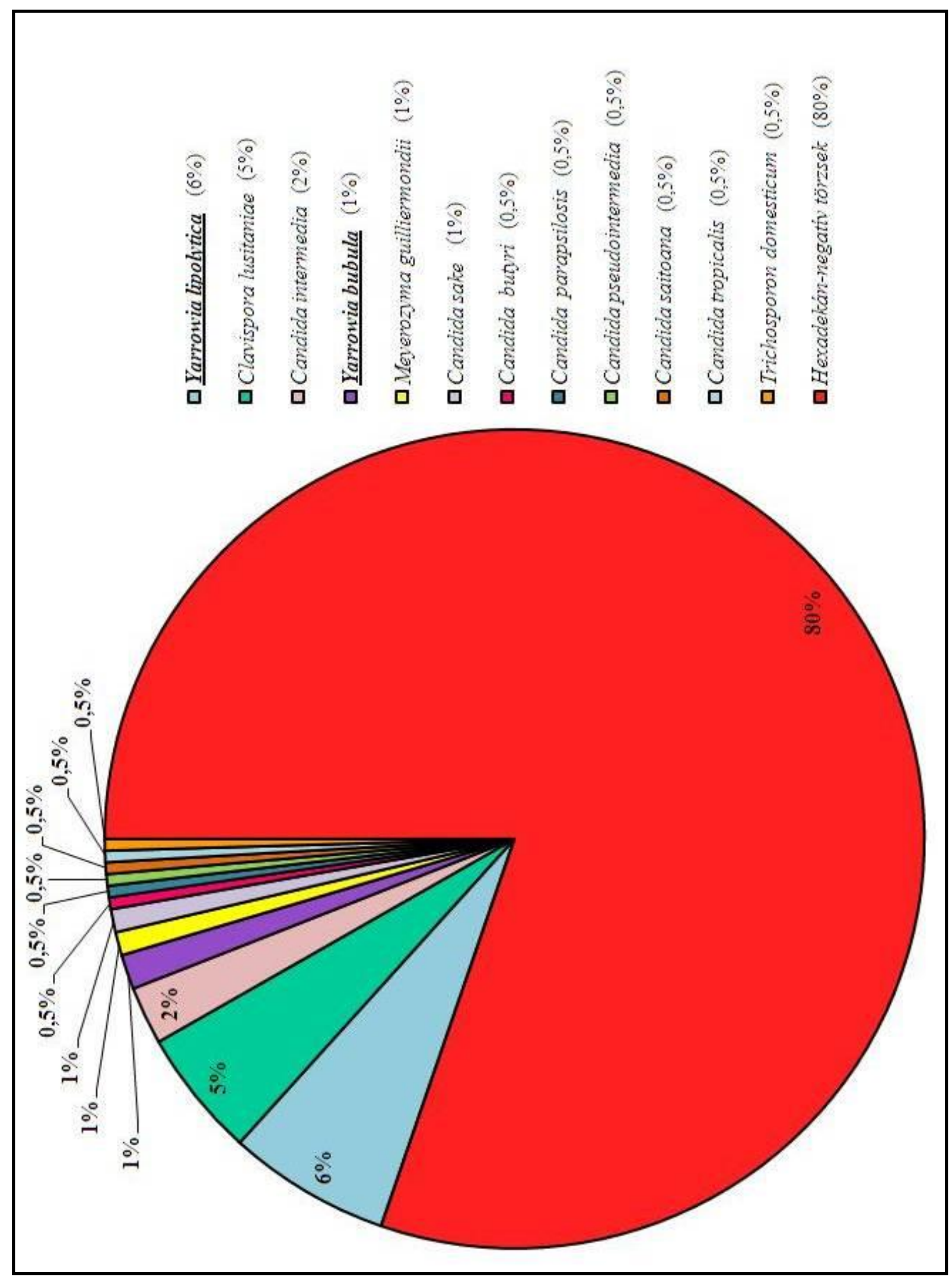

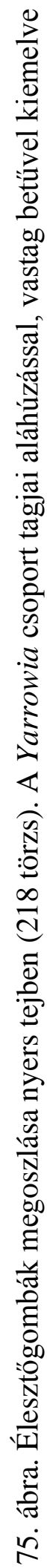




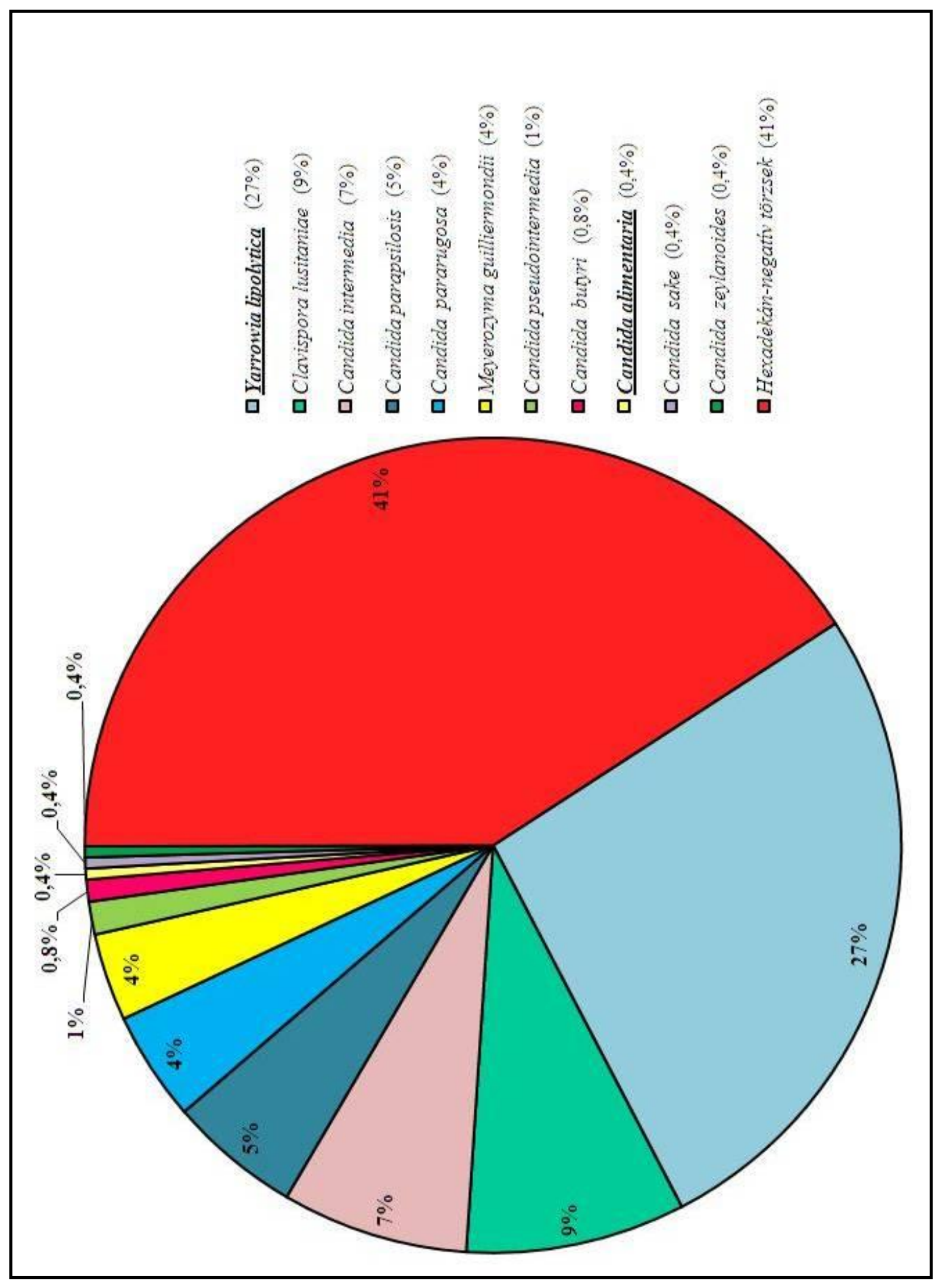

$\stackrel{0}{2}$

严

कृ

त्ञ

党

.

क्ञ⿰彳

5

ठㅇ

3)

ป

$\varangle$

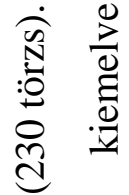

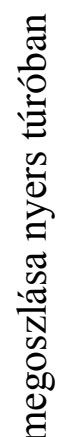

产

్ํㅇ

$=0$

婇

芼

$\stackrel{2}{2}$ 


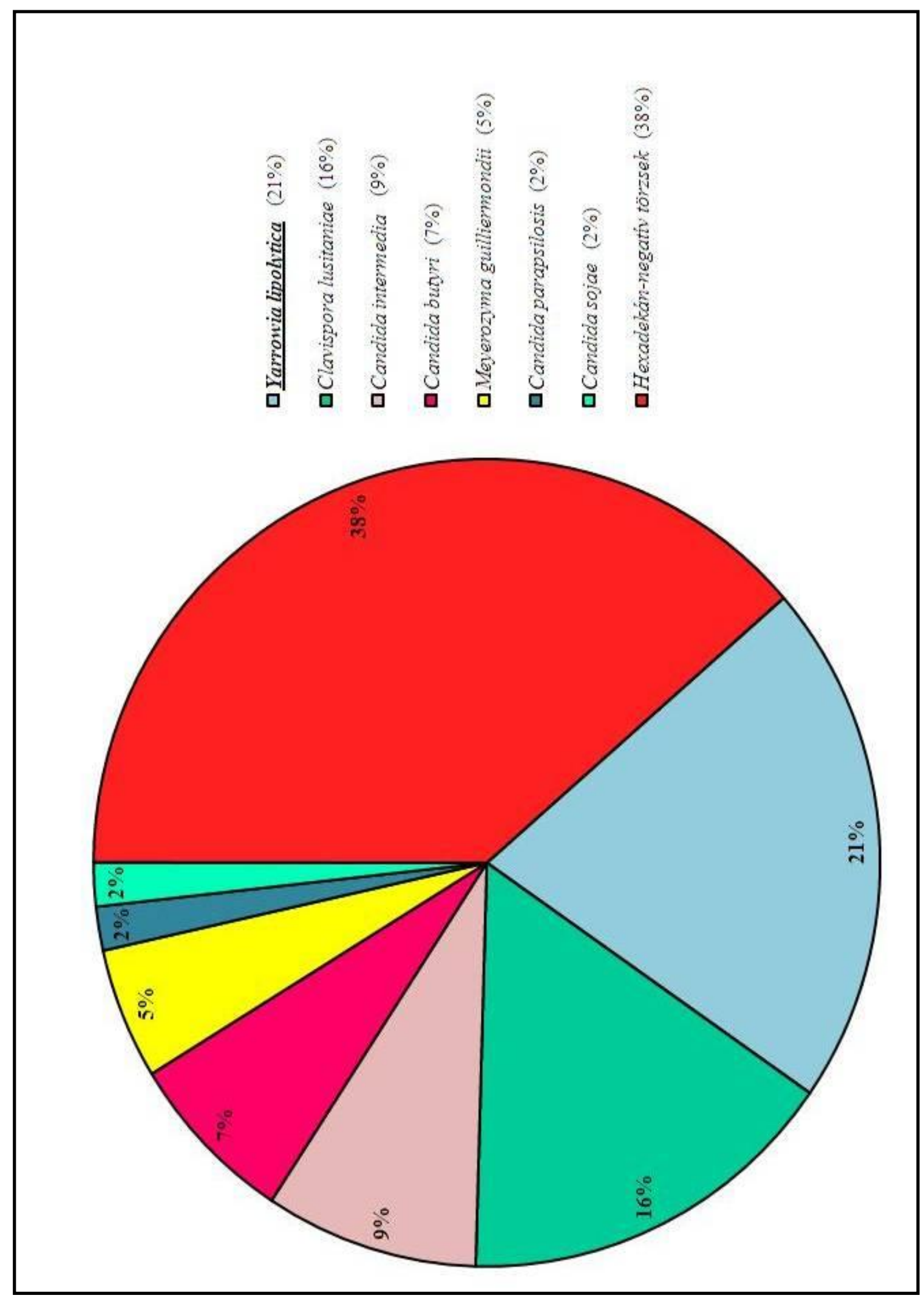

( 


\subsection{3. Új tudományos eredmények}

1. Új, hatékony izolálási módszert dolgoztam ki, mellyel nagy számban lehet Yarrowia csoportba tartozó élesztőgomba törzseket izolálni különböző élelmiszerekből: nyers húsból, nyers tejből, túróból, sajtból, ide értve több korábban leíratlan fajt is.

2. Nyolcszázhuszonhat izolált élesztőgombatörzs közül elkülönítettem a Yarrowia csoport tagjait, majd csoportosítottam őket. Megállapítottam, hogy a mikroszatellit primerrel végzett PCR technikával kapott mintázatok alapján a Yarrowia csoport tagjai kiválóan megkülönböztethetők egymástól. A csoportosítást követően csoportonként néhány törzs rRNS-ét kódoló génje D1/D2 régiójának szekvenáltatását követően fajszinten azonosítottam őket.

3. Felmértem a Yarrowia csoport biodiverzitását a vizsgált élelmiszerekben. A tapasztaltak alapján a Yarrowia lipolytica-n kívül nyers húsokban a Yarrowia csoport számos más tagja is képviselteti magát, ezzel szemben sajtból csak $Y$. lipolytica-t lehetett kimutatni, túróból a Yarrowia lipolytica-n kívül egy C. alimentaria törzset is izoláltam. Nyers tejböl izolált számos $Y$. lipolytica törzs mellett három $Y$. bubula törzset is sikerült kimutatni.

A Yarrowia csoport biodiverzitásán kívül feltérképeztem az egyéb hexadekán-asszimiláló élesztőgombák biológiai sokféleségét is a vizsgált élelmiszerekben.

4. Négy új, leíratlan fajhoz tartozó élesztőgomba törzseket izoláltam, melyek közül hármat új fajként írtunk le: Yarrowia divulgata, Yarrowia porcina és Yarrowia bubula névvel. A negyedik új faj leírásához további törzseket szeretnék izolálni. Aszkuszokat és aszkospórákat találtam a $Y$. porcina komplementer párosodási típusainak keverékében. A Y. porcina a nemzetség eddigi egyetlen ismert faja, amelynek aszkospórái tokanyagba ágyazódnak. A spórák életképességének alátámasztásaként csírázó aszkospórákat sikerült megfigyelnem és dokumentálnom.

5. Határozókulcsot készítettem a Yarrowia csoportba tartozó fajok fenotípusos tulajdonságain alapuló azonosításhoz, mely segítségével az eddig leírt 13 Yarrowia csoportba tartozó faj közül nyolcat el lehet egymástól különíteni.

6. Megvizsgáltam a Yarrowia csoportba tartozó törzsek (273 törzs) élelmiszerromláshoz potenciálisan hozzájáruló tulajdonságait és megállapítottam, hogy az összes vizsgált törzs rendelkezik legalább egy romlást okozó képességgel, de többségük több módon is veszélyt jelenthet az élelmiszerek minőségére lipolitikus és/vagy proteolitikus aktivitása, pigmenttermelő képessége miatt. 


\section{KÖVETKEZTETÉSEK ÉS JAVASLATOK}

A molekuláris módszereknek köszönhetően az utóbbi évtizedekben bebizonyosodott, hogy a mikroorganizmusok hagyományos módszereken alapuló azonosítása nem mindig megbízható. Világossá vált, hogy az élelmiszerekben és más élőhelyeken előforduló élesztőgombák diverzitása alulbecsült. Ezt alátámasztja az utóbbi években számos élelmiszereredetü új faj leírása, valamint az olyan kis számban előforduló fajok felfedezése, melyeket dúsítás nélkül lehetetlen lenne izolálni, nem beszélve arról, hogy korábban számos fajt tévesen azonosítottak, több hasonló fenotípusos tulajdonságú fajt egy fajnak véltek.

Az újonnan kidolgozott izolálási módszer eredményesen alkalmazható a Yarrowia csoportba tartozó élesztőgombák izolálására. A módszer hatékony, de nem teljes mértékben szelektív. Nyers húsban a Yarrowia csoport jelenleg ismert fajainak közel háromnegyede, legalább hét faj előfordul és izolálható az új módszer alkalmazásával. Ezzel szemben sajtból csak Yarrowia lipolytica törzseket izoláltam, túróból egy C. alimentaria törzs kivételével szintén csak Yarrowia lipolytica fajba tartozó törzseket lehetett kimutatni. Nyers tejből izolált számos $Y$. lipolytica törzs mellett három $Y$. bubula törzset is sikerült kimutatni.

A fenotípusos tulajdonságokon alapuló tesztek nagyon fontosak, de a kizárólag e tulajdonságok alapján történő azonosítás megbízhatósága sok esetben megkérdőjelezhető, a pontos azonosításhoz molekuláris biológiai módszerekre van szükség.

A Yarrowia csoportba tartozó törzsek többsége fiziológiai tesztekkel elkülöníthető a nem a csoportba tartozó törzsektől, azonban ezek a tesztek gyakran nem elegendök a különböző fajokhoz tartozó törzsek egymástól való elkülönítésére, erre a célra tapasztalatom szerint a mikroszatellit primerrel végzett PCR technika kíválóan megfelel. Bár a módszer jól múködött a tesztelt Yarrowia csoportba tartozó törzsek esetében, a Yarrowia csoporton kívüli számos törzsön végzett vizsgálat alapján úgy gondolom, hogy nagyobb sokféleséget mutató törzseket vizsgálva az MP-PCR felhasználásával felszaporított DNS fragmentek gélelektroforézisével nyert mintázatok alapján csak kellő körültekintéssel szabad következtetéseket levonni.

A Yarrowia csoport tagjainak fajszintü azonosításához néhány kivételes esettől eltekintve elég az rRNS-t kódoló gén D1/D2 régió szekvenciájának ismerete, csak ritkán van szükség az ITS szakaszok szekvenciájának vizsgálatára.

A Yarrowia lipolytica-ról számos tanulmányban élelmiszerromlást okozó mikroorganizmusként számolnak be, azonban a legtöbb esetben kizárólag hagyományos azonosítást alkalmaztak, így nagyon valószínü, hogy az esetek egy részében a Yarrowia csoport más tagja okozza a romlást. 
Az izolált törzsek fiziológiai tulajdonságainak vizsgálata hozzájárulhat az élelmiszeriparban hasznos vagy hátrányos szerepük felismeréséhez, valamint esetleges ipari vagy biotechnológiai alkalmazhatóságuk megbecsléséhez. Szükségesnek tartom a törzsgyüjteményekben Yarrowia lipolytica-ként számon tartott és különböző ipari területeken hasznosított, vagy a jövőben hasznosítani kívánt törzsek azonosításának molekuláris módszerekkel való megerősítését illetve felülvizsgálatát. 


\section{7. ÖSSZEFOGLALÁS}

A rendkívül erős lipolitikus és proteolitikus aktivitásáról, pigmenttermelő-képességéről ismert Yarrowia lipolytica az egyik legszéleskörübben tanulmányozott és élelmiszeripari szempontból az egyik legjelentősebbnek tartott élesztőgomba. Egyes élelmiszerekben az egyik leggyakrabban és legnagyobb számban előforduló élesztőgomba faj. Számos esetben teszik felelőssé élelmiszerek romlásáért, ezzel szemben rendkívül sok területen hasznosítható akár az élelmiszeriparban, akár a tisztítószer- vagy gyógyszeriparban, nem utolsó sorban környezetvédelemi szempontból is jelentős.

Az utóbbi években világossá vált, hogy nem egy fajról, hanem egy komplex csoportról van szó, melynek tagjait hagyományos módszerekkel sok esetben tévesen Yarrowia lipolytica-ként azonosítják. A Yarrowia csoport a következő fajokat foglalja magába: Y. lipolytica, Y. (C.) deformans, Y. (C.) yakushimensis, Candida galli, C. phangngensis, C. oslonensis, C. alimentaria, C. hollandica, C. hispaniensis, Y. divulgata, Y. keelungensis, Y. porcina, Y. bubula. Közülük a $Y$. lipolytica, $Y$. (C.) deformans, $Y$. divulgata, $Y$. keelungensis és $Y$. porcina nem különböztethetők meg egymástól sztenderd fenotípusos tulajdonságaik alapján. Ezen fajok egy úgynevezett fajkomplexet alkotnak. A fajok egymástól való megbízható elkülönítéséhez és fajszintű azonosításához molekuláris módszerekre van szükség. Ez alapján feltételezhető, hogy sok esetben nem is a $Y$. lipolytica, hanem a csoport valamely más tagja, esetleg tagjai felelősek az élelmiszerek romlásáért.

Vizsgálataim legfőbb célja az volt, hogy megismerjem a Yarrowia csoport biodiverzitását különböző élelmiszerekben (nyers húsokban, nyers tejben, lejárt fogyaszthatósági idejü sajtokban és túróban).

Mindenekelőtt szükséges volt egy olyan módszer kidolgozása, mely alkalmas a csoport tagjainak hatékony izolálására. Ehhez egy olyan dúsító táplevest készítettem, ami elősegíti a Yarrowia csoportba tartozó törzsek dominanciáját a dúsító levesben, lehetővé téve nagy számban történő izolálásukat. A dúsító tápleves $\mathrm{pH}$ értéke 3,6 (így a baktériumok többségének szaporodása gátolható), és olyan specifikus szénforrást (hexadekánt) tartalmaz, amit a Yarrowia csoport tagjain kívül az ismert élesztőgombafajoknak csak kis hányada képes asszimilálni (így a dúsító tápleves az élesztőgombák zömének szaporodását nem teszi lehetővé). Később a hatékonyság fokozása érdekében módosítottam a dúsító tápleves összetételét. A későbbiek során bebizonyosodott, hogy a Yarrowia csoportba tartozó törzsek izolálása szempontjából valóban nagyobb hatékonyságot lehet elérni a módosított dúsító tápleves alkalmazásával. 
$\mathrm{Az}$ újonnan kidolgozott módszerekkel 826 élesztőgombatörzset izoláltam a vizsgált élelmiszerekből.

Az izolálást követően kiválasztottam közülük a Yarrowia csoportba tartozó törzseket. Ennek első lépése az volt, hogy elkülönítettem a hexadekán-asszimilációra képes törzseket a hexadekán-negatívaktól. Erre egy egyedüli szénforrásként hexadekánt tartalmazó tápközeg segítségével került sor. Második lépésként a hexadekán-pozitív törzseket API ID 32C teszttel vizsgálva elkülönítettem azokat a törzseket, melyek fiziológiai tulajdonságaik alapján a Yarrowia csoport tagjai lehetnek. Teszteltem 30 különböző szénforrás, valamint nitrát asszimilációját, glükóz erjesztését és a törzsek cikloheximid jelenlétében való szaporodásának képességét. Ily módon 219 törzset különítettem el a Yarrowia csoport tagjaként.

Ezután a kiválasztott törzsek csoportosítása következett, erre a célra kiválónak bizonyult az MP-PCR módszer, ami segítségével molekuláris ujjlenyomatuk alapján el lehetett különíteni egymástól az egyes fajokat, sőt gélmintázatukat a referenciaként használt típustörzsek mintázataihoz hasonlítva előzetesen meg lehetett állapítani, hogy melyik törzs melyik fajhoz tartozik. Az MP-PCR felhasználásával felszaporított DNS fragmentumok gélelektroforézises elválasztásával kapott mintázatuk alapján hét csoportba soroltam a törzseket. Mind a hét csoportban képviseltették magukat a nyers húsból izolált törzsek, nyers tejből és tejtermékekböl izolált törzsek egy túróból izolált $C$. alimentaria és három nyers tejből izolált $Y$. bubula törzs kivételével egyetlen csoportot alkottak.

A megbízható fajszintű azonosításhoz azonban a riboszómális RNS-t kódoló gén egyes régióinak vizsgálatára volt szükség. A szakirodalommal egybehangzóan legtöbb esetben elegendő volt a 26S rRNS-t kódoló gén D1/D2 régiójának szekvencia-analízise, néhány kivételes esetben azonban szükséges volt az ITS szakaszok vizsgálatát is bevonni az azonosításba. Az említett génszakasz(ok) PCR-rel történő felszaporítása után azok szekvenáltatására került sor, majd a kapott szekvenciákat a GenBank adatbázisának felhasználásával összehasonlítottam a Yarrowia csoport típustörzseinek szekvenciáival. Ily módon sikerült fajszinten azonosítani a kiválasztott törzsek többségét.

Néhány törzs szekvenciájához kellő mértékben hasonlító szekvencia azonban nem volt megtalálható a GenBank-ban, vagy még leíratlan fajhoz tartozott. Ezekről a törzsekről további vizsgálatok alapján bebizonyosodott, hogy korábban ismeretlen új fajok tagjai, azóta közülük három lerására (Yarrowia divulgata, Yarrowia porcina és Yarrowia bubula) került sor, a negyedik új faj leírása még várat magára, mivel eddig csak egy törzs áll rendelkezésre, a leíráshoz több e fajhoz tartozó törzset szeretnék izolálni. 
A fajszintü azonosítást követően meghatároztam a Yarrowia csoport diverzitását a vizsgált élelmiszerekben. Nyers húsból a hét különböző gélmintázatnak megfelelően hét fajt lehetett kimutatni. A Yarrowia csoportba sorolt törzseknek csak 21\%-a Y. lipolytica (28 törzs a 135-ből), a törzsek többsége $Y$. deformans. Kisebb számban volt köztük $C$. galli, C. alimentaria és a fent említett három új faj tagjai. A húsból izolált, Yarrowia csoportba sorolt törzsek $42 \%$-a ( $Y$. deformans, $Y$. divulgata és $Y$. porcina) hagyományos módszereket alkalmazva valószínűleg hibásan lett volna azonosítva. A Yarrowia csoport tagjainak nyers húsokban tapasztalt változatosságával szemben, három nyers tejből izolált $Y$. bubula törzs és egy túróból izolált $C$. alimentaria törzs kivételével a tejtermékekböl csak $Y$. lipolytica volt kimutatható. Az összes Yarrowia csoportba tartozó izolátum megoszlását vizsgálva azt tapasztaltam, hogy csak 51\%-uk Y. lipolytica. Az összes Yarrowia csoportba tartozó izolátum 26\%-a kizárólag hagyományos módszerekkel vizsgálva valószínűleg tévesen $Y$. lipolytica-ként lett volna azonosítva.

Az azonosított Yarrowia csoportba tartozó törzseket vizsgálva megpróbáltam fenotípus alapján történő elkülönítési lehetőségeket találni. Ehhez először össze kellett gyüjtenem az egyes fajok fiziológiai tulajdonságairól a rendelkezésre álló adatokat. Felhasználtam a CBS adatbázist, a jelenlegi legfrissebb monográfiát és a fajleírásokat. Az így összegyüjtött adatokat összegeztem, ahol ellentmondás volt, vagy nem állt rendelkezésre adat, azokat a fiziológiai teszteket magam is elvégeztem, majd táblázatot készítettem az eredményekről. Az így nyert adatok felhasználásával határozókulcsot készítettem, mely segítségével bizonyos fenotípusos tulajdonságokat vizsgálva elkülöníthető egymástól a C. alimentaria, C. galli, C. hispaniensis, C. hollandica, C. oslonensis, C. phangngensis, Y. bubula és a Y. yakushimensis. A többi Yarrowia csoportba tartozó faj ( $Y$. deformans, $Y$. divulgata, $Y$. keelungensis, $Y$. lipolytica és $Y$. porcina) törzsei nem különíthetők el fenotípusos tulajdonságok alapján, úgynevezett fajkomplexet alkotnak. Bár a Yarrowia csoport fajainak egy része a jelenleg rendelkezésre álló adatok alapján fenotípusos bélyegek alapján is elválasztható egymástól, a határozó kulcs önmagában sajnos nem elegendő a fent említett törzsek teljes mértékben megbízható azonosításához, hiszen nem veszi figyelembe a még fel nem ismert esetleges fajon belüli fenotípusos variabilitást és a csoportba tartozó leíratlan fajokat. Emiatt célszerủ a Yarrowia csoport fajait D1/D2, és ha szükséges ITS szekvenciáik alapján azonosítani.

Vizsgáltam a rendelkezésemre álló összes általam izolált Yarrowia csoportba tartozó törzs és referencia törzs (273 törzs) azon tulajdonságait, melyek a szakirodalom szerint potenciálisan hozzájárulnak az élelmiszerek romlásához, vagyis pigmentképző-, fehérjebontó- és zsírbontó-képességét. A pigmenttermelő-képességet tirozintartalmú táptalajon vizsgáltam, a lipolitikus aktivitást 5\% olívaolajjal kiegészített Gorodkowa agarlemezen, a fehérjebontó képességet pedig zselatin-hidrolízis tesztelése által mértem fel. Az ezzel kapcsolatos 
eredményekből megállapítható, hogy az összes eddig vizsgált Yarrowia csoportba tartozó törzs rendelkezik legalább egy élelmiszerromláshoz hozzájáruló képességgel, de többségük több módon is veszélyt jelenthet az élelmiszerek minőségére. Ez összhangban van a szakirodalomban említett tapasztalatokkal, mely szerint a Y. lipolytica (és a Yarrowia csoport tagjai) igen fontos szerepet játszanak az élelmiszerek romlásában.

A Yarrowia csoportba tartozó fajok közül sokáig csak egyetlen fajnak, a Y. lipolytica-nak ismerték a teleomorf (ivaros) alakját. A közelmúltban számoltak be a $C$. deformans teleomorf alakjáról, átsorolva a fajt a Yarrowia nemzetségbe. A Yarrowia csoportba tartozó törzsek fajon belüli párosodási képességét vizsgálva azt tapasztaltam, hogy a $Y$. porcina fajba tartozó néhány törzs képes egymással párosodni és aszkospórákat képezni, így háromra növekedett a Yarrowia csoport ismert ivaros alakkal rendelkező fajainak száma. A Y. porcina a nemzetség eddigi egyetlen ismert faja, amelynek aszkospórái tokanyagba ágyazódnak. Ez a tulajdonság az összes élesztőgomba között is igen ritka. A spóráztatáshoz használt kevert tenyészeteket megőriztem, és több mint három hónap elteltével nem csak sporangiumban lévő és kiszabadult spórákat találtam, hanem azok csírázását is sikerült megfigyelnem és dokumentálnom, ezzel bizonyítva az aszkospórák életképességét.

Mivel a leírt élesztőgombafajok csak kis hányadáról ismert, hogy képes a hexadekán asszimilációjára, kíváncsi voltam, hogy a vizsgálataim során izolált, nem a Yarrowia csoportba tartozó hexadekán-pozitív törzsek milyen fajokhoz tartoznak. Részben emiatt, részben pedig további új fajokhoz tartozó törzsek azonosításának reményében vizsgáltam azokat az általam izolált hexadekán-pozitív törzseket (175 törzs), melyeket fiziológiai tulajdonságaik alapján nem soroltam a Yarrowia csoportba. MP-PCR felhasználásával felszaporított DNS fragmentek gélelektroforézisével nyert mintázatuk alapján csoportosítva, majd szekvenciáik alapján azonosítva őket meghatároztam, hogy milyen arányban oszlanak meg ezek a fajok a vizsgált élelmiszerekben. A hexadekán-pozitív de a Yarrowia csoportba nem tartozó élesztőgomba törzsek jóval nagyobb diverzitást mutattak az élelmiszerekben, mint a csoport tagjai. Azonosításuk során a legtöbb esetben a Yarrowia csoport tagjaihoz hasonlóan azt tapasztaltam, hogy a kiválasztott törzsek szekvenáltatása után, a kapott szekvenciák GenBank adatbázisban található szekvenciákkal való összehasonlítása alapján történt azonosítás eredménye megegyezett a törzsek MP-PCR segítségével kapott fragmentumok gélelektroforézises mintázata alapján történt feltételes csoportosítással. Ezeknek a törzseknek a vizsgálata során azonban nem minden esetben tudtam előre megbecsülni a faji hovatartozást a gélmintázat alapján. A Yarrowia csoport tagjainál tapasztaltakkal ellentétben több esetben tapasztaltam, hogy különböző törzsekből (GAC)5 primer felhasználásával felszaporított DNS fragmentek gélelektroforézissel 
nyert mintázatai különböznek, mégis ugyanannak a fajnak a tagjai. Ez összhangban van Ramírez-Castrillón 2014-ben megjelent tanulmányának következtetésével, mely szerint az élesztőgomba törzsek MP-PCR alapú csoportosítása nem teljes mértékben megbízható. Az egyes csoportok nem feltétlenül csak azonos fajhoz tartozó törzseket tartalmaznak és azonos fajhoz tartozó törzsek különböző csoportokba is kerülhetnek. Bár a módszer jól müködött az általam tesztelt Yarrowia csoportba tartozó törzsek esetében, úgy gondolom, hogy nagyobb sokféleséget mutató törzseket vizsgálva MP-PCR felhasználásával felszaporított DNS fragmentek gélelektroforézisével nyert mintázatuk alapján csak kellö körültekintéssel szabad következtetéseket levonni.

Az összes általam izolált hexadekán-pozitív élesztőgomba törzs fajszintü azonosítása után vizsgáltam az izolálási forrásul szolgáló élelmiszerekben való megoszlásukat, jelentős részük, 49\%-uk a Yarrowia csoportba tartozott. 
DOI: 10.14267/phd.2015033 


\section{SUMMARY}

Yarrowia lipolytica is one of the most extensively studied and one of the most important yeast species in the food industry, known from its remarkably high lipolytic and proteolitic activity, and its ability to produce brown pigments. It is one of the most common yeast species in specific types of food. In many cases $Y$. lipolytica is believed to be responsible for food spoilage, nevertheless this species has been developed as a production host for a large variety of biotechnological applications and can be used in the food-, detergent- and pharmaceutical industry as well as in environmental protection.

In the last twelve years the Yarrowia clade has expanded. Currently, instead of the single species $Y$. lipolytica, it comprises of the following species: Y. lipolytica, $Y$. (C.) deformans, $Y$. (C.) yakushimensis, Candida galli, C. phangngensis, C. oslonensis, C. alimentaria, C. hollandica, C. hispaniensis, Y. divulgata, Y. keelungensis, Y. porcina, Y. bubula. Using conventional methods some members of the genus Yarrowia can easily be misidentified as $Y$. lipolytica. These species are $Y$. (C.) deformans, Y. divulgata, Y. keelungensis and $Y$. porcina. As they cannot be differentiated based on their standard phenotypic characteristics, together with $Y$. lipolytica they form the so-called $Y$. lipolytica species complex. To differentiate and identify these species reliably, molecular methods are needed. Considering this, it is presumable that in some cases not only $Y$. lipolytica but other members of this species complex are responsible for food spoilage.

The primal aim of my investigations was to recognise the diversity of the Yarrowia clade in different kinds of food (raw meat, raw milk, expired cheese and cottage cheese).

First of all working out a new method for the effective isolation of members of the Yarrowia clade was necessary. I prepared an enrichment medium to promote the dominance of strains of the Yarrowia clade over other yeast strains, thus their isolation in a large number was enabled. The $\mathrm{pH}$ of the enrichment medium is 3.6 (thus the growth of most of the bacteria is inhibited), and it containes a specific carbon source (hexadecane), which can be assimilated only by a small proportion of the known yeast species including the species of the Yarrowia clade (thus this medium does not support the growth of most of the yeast species outside the Yarrowia clade). To enhance the efficiency of the enrichment medium I modified its ingredients. Isolation of strains of the Yarrowia clade by using this modified medium proved to be more efficient actually.

Eight hundred twenty-six yeast strains were isolated by using this newly developed method. After the isolation, members of the Yarrowia clade were selected. First, hexadecane 
assimilating yeast strains were separated from the hexadecane-negative ones by using a medium containing hexadecane as a sole carbon source. Based on their physiological characteristics possible members of the Yarrowia clade were then separated by examining the hexadecanepositive strains by using API ID 32C tests. Two hundred and nineteen strains were separated in this way, as members of the Yarrowia clade.

These selected strains were then assigned to groups. For that microsatellite-primed-PCR method proved to be effective, because strains of different species could be successfully discriminated based on their DNA fingerprints, even their identity could be assessed by compairing their fingerprints to the fingerprints of the type strains of the Yarrowia clade. Strains were assigned to seven groups based on their fingerprints obtained from the gel electrophoretic separation of their DNA fragments amplified by using microsatellite-primed PCR. Strains isolated from raw meat were present in all the seven groups, however, strains from raw milk and milk products formed only one group with only few exception.

To confirm the identity of the strains sequencing of the D1/D2 domain of the LSU rRNA gene was necessary. Selected members of each group were identified by amplifying and sequencing the D1/D2 region of the ribosomal RNA's large subunit coding gene which proved to be sufficient in most of the cases, but in some extraordinary cases examination of the ITS regions were also needed for the reliable identification. PCR amplification of the above mentioned gene regions was followed by sequencing, then sequence similarity searches were performed against the GenBank sequence database. Sequences of the strains isolated by me were compared to the sequences of the type strains of the Yarrowia clade. Thus identification of the majority of the strains at species level was successful.

However, the search in the GenBank database did not reveal sufficiently close match to the sequences of some strains or in some other cases the closest matches were sequences of unrecognised species. Further examination of these strains revealed that they were members of unrecognised species. Since then three of them had been described (Yarrowia divulgata, Yarrowia porcina and Yarrowia bubula) and a fourth one will be described in the future, because at the moment I have only one strain of this species and for the description I would like to isolate some more strains belonging to this new species.

Following the identification at species level, diversity of the Yarrowia clade had been assessed in the examined foods. Seven species had been revealed from meat, corresponding to the seven different fingerprints obtained after gelelectrophoretic separation of the DNA amplified by using microsatellite-primed-PCR. Only $21 \%$ of the strains ( 28 of the 135 strains) proved to be $Y$. lipolytica, the majority of the strains were $Y$. deformans. In a smaller proportion 
C. galli, C. alimentaria, and strains of the above mentioned three new spesies also occured in meat. Fourty-two percent of the strains isolated from meat and assigned as members of the Yarrowia clade ( $Y$. deformans, $Y$. divulgata and $Y$. porcina) probably would have been misidentified by using conventional methods, as Y. lipolytica

Contrary to such adiversity of Yarrowia and Yarrowia related species in raw meat, besides the three $Y$. bubula strains from milk and one C. alimentaria strain from cottage cheese, only $Y$. lipolytica were detected in milk and milk products. Fifty-one percent of all the strains belonging to the Yarrowia clade proved to be Y. lipolytica. By using only conventional methods $56 \%$ of all the isolates belonging to the Yarrowia clade probably would have been misidentified as $Y$. lipolytica.

The possibilities of differentiating the strains based on their phenotypic characteristics were examined. First all the available data on the phisiological characteristics of the species of the Yarrowia clade had to be collected. Data were obtained from the CBS database, the newest monography and the descriptions of the species, then they were integrated. In case of contradictions or lacking data the particular characteristics were tested by myself, then a summarizing table of these data was constructed. Using these datas a taxonomic key to the species was compiled. Using this taxonomic key, C. alimentaria, C. galli, C. hispaniensis, C. hollandica, C. oslonensis, C. phangngensis, $Y$. bubula, and $Y$. yakushimensis can be discriminated based on some of their physiological characteristics. Strains of other species of the Yarrowia clade ( $Y$. deformans, Y. divulgata, Y. keelungensis, Y. lipolytica and Y. porcina) cannot be differentiated based on their phenotypic characteristics, thus they form a so-called speciescomplex. Although some species of the Yarrowia clade can be differentiated based on the available data of their phenotypic characteristics, unfortunately the taxonomic key in itself is not enough to identify the above mentioned strains infallibly, since it does not consider yet unnoticed potentional variations within species or undescribed species. Thus reliable identification of the species of the Yarrowia clade has to be based on their D1/D2 and if neccessary on their ITS sequences.

Potential spoilage causing characteristics of all the strains belonging to the Yarrowia clade and also the strains used as reference (273 strains) were tested, namely their lipolytic and proteolytic activity and their ability to produce brown pigments. Pigment production was tested on a media containing tyrosine, lipolytic activity was tested on Gorodkowa agar supplemented with $5 \%$ olive oil, and proteolytic activity was assessed by gelatin liquefaction. Based on the results it can be stated, that each tested strain of the Yarrowia clade owns at least one of the potential spoilage-causing characteristics, moreover most of them mean multiple risk to the food 
quality. It corresponds to the information found in the literature, that $Y$. lipolytica (and other members of the Yarrowia clade) play a prominent role in food spoilage.

For a long time $Y$. lipolytica was the only species of the Yarrowia clade with known teleomorphic state. Recently, teleomorphic state of $C$. deformans was found, thus this species was transferred to the Yarrowia genus. Examining the intra-species mating ability between strains of the Yarrowia clade, mating and ascosporulation had been observed in the mixture of some $Y$. porcina strains, thus this species emerged as the third teleomorphic species of the Yarrowia clade. $Y$. porcina is the only species of the genus with ascospores embedded in capsular material. This feature is quite rare even among the entire yeast domain. The culture used for ascosporulation was preserved, and after more than three months not only asci and ascospores could be found but also budding of the ascospores was observed and documented proving the viability of the ascospores.

Since hexadecane assimilation is a quite rare feature, only a small proportion of yeast species is known of being capable of assimilating it, I was curious, what species the hexadecane-positive isolates outside the Yarrowia clade belonged. This and the hope of finding new species prompted me to examine these hexadecane assimilating strains that were not assigned to the Yarrowia clade (175 strains) based on their physiological characteristics. Following their grouping based on their fingerprints obtained from the gelelectrophoretic separation of their DNA fragments amplified by using microsatellite-primed PCR, and their identification based on their above mentioned sequences, their diversity was determined in the examined foods. These strains showed much greater diversity in food, than the members of the Yarrowia clade. During their identification I experienced the same thing as in the case of the strains of the Yarrowia clade, namely, that the sequence-based identification was congruent with the preliminary grouping based on microsatellite-primed-PCR fingerprint analysis. However, due to the absence of reliable reference strains, their identity could not be assessed in advance in each case based on their DNA fingerprints. Unlike in the case of strains of the Yarrowia clade, in some cases conspecific strains showed different fingerprints of DNA fragments amplified by using (GAC) 5 primer and separated with gel electrophoresis. It corresponds to the conclusion of the study of RamírezCastrillón (2014), which says clustering yeast strains based on microsatellite-primed PCR is not fully reliable. Some groups can contain strains belonging to different species, and conspecific strains can be assigned to different groups. Although this method was successful in case of the strains of the Yarrowia clade, only cautious inferences should be drawn when studying strains showing greater diversity. 
Following species level identification of all the isolated hexadecane-assimilating yeast strains, their distribution was studied in the examined foods, a remarkable proportion, $49 \%$ belonged to the Yarrowia clade. 
DOI: 10.14267/phd.2015033 


\section{IRODALOMJEGYZÉK}

Abunyewa A.A.O., Laing E., Hugo A., Viljoen B.C. (2000). The population change of yeasts in commercial salami. Food Microbiology, 17:429-438. p. DOI: http://dx.doi.org/10.1006/fmic.1999.0333

Addis E., Fleet G.H., Cox J.M., Kolak D., Leung T. (2001): The growth, properties and interactions of yeasts and bacteria associated with the maturation of Camembert and blueveined cheeses. International Journal of Food Microbiology, 69:25-36. p. DOI: http://dx.doi.org/10.1016/S0168-1605(01)00569-4

Amaral P.F., Lehocky M., Barros-Timmons A.M., Rocha-Leão M. H. M. (2006): Cell surface characterization of Yarrowia lipolytica IMUFRJ 50682. Yeast, 23:867-877. p. DOI: http://dx.doi.org/10.1002/yea.1405

Ashengroph M., Nahvi I., Zarkesh-Esfahani H., Momenbeik F. (2011): Candida galli strain PGO6: a novel isolated yeast strain capable of transformation of isoeugenol into vanillin and vanillic acid. Current Microbiology, 62:990-998. p. DOI: http://dx.doi.org/10.1007/s00284-010-9815-y

Bai M., Qing M., Guo Z., Zhang Y., Chen X., Bao Q., Zhang H., Sun T. (2010): Occurrence and dominance of yeast species in naturally fermented milk from the Tibetan Plateau of China. Canadian Journal of Microbiology, 56:707-714. p. DOI: http://dx.doi.org/10.1139/W10$\underline{056}$

Bailey R.B., Madden K.T., Trueheart J., et al. (2008). Production of carotenoids in oleaginous yeast and fungi. International Patent Application WO 2008/042338 A2.

Baleiras Couto M.M., Hartog B.J., Huis in’t Veld J.H.J., Hofstra H., Van der Vossen J.M.B.M. (1996a): Identification of spoilage yeasts in a food-production chain by microsatellite polymerase chain reaction fingerprinting. Food Microbioogy, 13:59-67. p. DOI: http://dx.doi.org/10.1006/fmic.1996.0008

Baleiras Couto M.M., Eijsma B., Hofstra H., Huis in’t Veld J.H.J., van der Vossen J.M.B.M. (1996b): Evaluation of molecular typing techniques to assign genetic diversity among strains of Saccharomyces cerevisiae. Applied and Environmental Microbiology, 62 (1):4146. $\mathrm{p}$. 
Bankar A.V., Kumar A.R., Zinjarde S.S. (2009): Environmental and industrial applications of Yarrowia lipolytica. Applied Microbiology and Biotechnology, 84:847-865. p. DOI: http://dx.doi.org/10.1007/s00253-009-2156-8

Banks J.G., Board R.G. (1987): Some factors influencing the recovery of yeasts and moulds from chilled foods. International Journal of Food Microbiology, 4:197-206. p. DOI: http://dx.doi.org/10.1016/0168-1605(87)90037-7

Belaj A., Satovic Z., Cipriani G., Baldoni L., Testolin R., Rallo L., Trujillo I. (2003): Comparative study of the discriminating capacity of RAPD, AFLP and SSR markers and of their effectiveness in establishing genetic relationships in olive. Theoretical and applied genetics, 107:736-744 p. DOI: http://dx.doi.org/10.1007/s00122-003-1301-5

Bialecka-Florjanczyk E., Krzyczkowska J., Stolarzewicz I., Kapturowska A. (2012): Synthesis of 2-phenylethyl acetate in the presence of Yarrowia lipolytica KKP 379 biomass. Journal of Molecular Catalysis B-Enzymatic, 74:241-245. p. DOI: http://dx.doi.org/10.1016/j.molcatb.2011.10.010

Bigey F., Tuery K., Bougard D., Nicaud J., Moulin G. (2003): Identification of a triacylglycerol lipase gene family in Candida deformans: molecular cloning and functional expression. Yeast, 20:233-248. p. DOI: http://dx.doi.org/10.1002/yea.958

Bintsis T., Robinson R.K. (2004): A study of the effects of adjunct cultures on the aroma compounds of Feta-type cheese. Food Chemistry, 88:435-441. p. DOI: http://dx.doi.org/10.1016/j.foodchem.2004.01.057

Booth J.L., Vishniac H.S. (1987): Urease testing and yeast taxonomy. Canadian Journal of Microbiology, 33 (5):396-404. p. DOI: http://dx.doi.org/10.1139/m87-069

Botes A.L., Mitra R.K. (2006): Epoxide hydrolases: a biocatalytic technology platform for the production of chiral pharmaceutical intermediates. The Pharmaceutical Technology Journal, 21:86-89. p.

Botes AL, Labuscagne M, Roth R, et al. (2007). Recombinant yeasts for synthesizing epoxide hydrolases. International Patent Application WO 2007/010403 A2. 
Bourdichon F., Casaregola S., Farrokh C., Frisvad J.C., Gerds M.L., Hammes W.P., Harnett J., Huys G., Laulund S., Ouwehand A., Powell I.B., Prajapati J.B., Set Y., Schure E.T., Boven A.V., Vankerckhoven V., Zgoda A., Tuijtelaars S., Hansen E.B. (2012): Food fermentations: microorganisms with technological beneficial use. International Journal of Food Microbiology, 154:87-97. p. http://dx.doi.org/10.1016/j.ijfoodmicro.2011.12.030

Brocklehurst T.F., Lund B.M. (1985): Microbiological changes in cottage cheese varieties during storage at $7^{\circ}$ C. Food Microbiology, 2:207-233. p. DOI: http://dx.doi.org/10.1016/0740$\underline{0020(85) 90036-X}$

Buick R.K., Damoglou A.P. (1989): Effect of modified atmosphere packaging on the microbial development and visible shelf life of a mayonnaise-based vegetable salad. Journal of the Science of Food and Agriculture, 46:339-347. p. DOI: http://dx.doi.org/10.1002/jsfa.2740460312

Cantor M.D., van den Tempel T., Hansen T.K., Ardö Y. (2004): Blue cheese. 175-195. p. In: Fox P.F., McSweeney P.L.H., Cogan T.M., Guinee T.P. (Szerk.) Cheese: chemistry, physics and microbiology, Vol 2: major cheese groups. London: Elsevier Academic Press, 450 p. ISBN: 978-0-12-263653-0

Carreira A., Loureiro V. (1998): A differential medium to detect Yarrowia lipolytica within 24 hours. Journal of Food Mycology, 1:3-12. p.

Carreira A., Paloma L., Loureiro V. (1998): Pigment producing yeasts involved in the brown surface discoloration of ewes' cheese. International Journal of Food Microbiology, 41:223-230. p. DOI: http://dx.doi.org/10.1016/S0168-1605(98)00054-3

Carreira A., Ferreira L., Loureiro V. (2001): Brown Pigments Produced by Yarrowia lipolytica Result from Extracellular Accumulation of Homogentisic Acid. Applied and Environmental Microbiology, 67 (8):3463-3468. p. $\quad$ DOI: http://dx.doi.org/10.1128/AEM.67.8.3463-3468.2001

Carreira A., Dillinger K., Eliskases-Lechner F., Loureio V., Ginzinger W., Rohm H. (2002): Influence of selected factors on browning of Camembert cheese. The Journal of Dairy Research 69 (2):281-292. p. DOI: http://dx.doi.org/10.1017/S0022029902005393 
Caruso M., Capece A., Salzano G., Romano P. (2002): Typing of Saccharomyces cerevisiae and Kloeckera apiculata strains from Aglianico wine. Letters in Applied Microbiology, 34:323328. p. DOI: http://dx.doi.org/10.1046/j.1472-765X.2002.01090.x

Chang C.-F., Chen C-C., Lee C.-F., Liu S.-M. (2013): Identifying and characterizing Yarrowia keelungensis sp. nov., an oil-degrading yeast isolated from the sea surface microlayer. Antonie van Leeuwenhoek, 104 (6):1117-1123. p. DOI: http://dx.doi.org/10.1007/s10482$\underline{013-0033-\mathrm{Z}}$

Chatzifragkou A., Makri A., Belka A., Bellou S., Mavrou M., Mastoridou M., Mystrioti P., Onjaro G., Aggelis G., Papanikolaou S. (2011): Biotechnological conversions of biodiesel derived waste glycerol by yeast and fungal species. Energy, 36:1097-1108. p. DOI: http://dx.doi.org/10.1016/j.energy.2010.11.040

Chen Y.-C., Eisner J.D., Kattar M.M., Rassoulian-Barrett S.L., LaFe K., Yarfitz S.L., Limaye A.P., Cookson B.T. (2000): Identification of medically important yeasts using PCR based detection of DNA sequence polymorphisms in the internal transcribed spacer 2 region of the rRNA genes. Journal of Clinical Microbiology, 38:2302-2310. p.

Chen L.-S., Ma Y., Maubois J.-L., Chen L.-J., Liu Q.-H., Guo J.-P. (2010): Identification of yeasts from raw milk and selection for some specific antioxidant properties. International Journal of Dairy Technology, 63:47-54. p. DOI: http://dx.doi.org/10.1111/j.1471$\underline{0307.2009 .00548 . x}$

Chuang L.T., Chen D.C., Nicaud J.M., Madzak C., Chen Y.-H., Huang Y.-S. (2010): Coexpression of heterologous desaturase genes in Yarrowia lipolytica. New Biotechnology, 27:277-282. p. DOI: http://dx.doi.org/10.1016/j.nbt.2010.02.006

Cirigliano M.C., Carman G.M. (1985): Purification and characterization of liposan, a bioemulsifier from Candida lipolytica. Applied and Environmental Microbiology, 50:846850. p.

Corbo M.R., Lanciotti R., Albenzio M., Sinigaglia M. (2001): Occurrence and characterization of yeasts isolated from milks and dairy products of Apulia region. International Journal of Food Microbiology, 69:147-152. p. DOI: http://dx.doi.org/10.1016/S0168-1605(01)00585$\underline{2}$ 
Damude HG, Gillies PJ, Macool DJ, et al. (2009a). High arachidonic acid producing strains of Yarrowia lipolytica. United States Patent 7,588,931.

Damude HG, Macool DJ, Picataggio SK, et al. (2009b). Docosahexaenoic acid producing strains of Yarrowia lipolytica. United States Patent 7,550,286 B2.

Daniel H.M., Vrancken G., Takrama J.F., Camu N., De Vos P., De Vuyst L. (2009): Yeast diversity of Ghanaian cocoa bean heap fermentations. FEMS Yeast Research, 9(5): 774783 p. DOI: http://dx.doi.org/10.1111/j.1567-1364.2009.00520.x

Daryaei H., Coventry J., Versteeg C., Sherkat F. (2010): Combined pH and high hydrostatic pressure effects on Lactococcus starter cultures and Candida spoilage yeasts in a fermented milk test system during cold storage. Food Microbiology, 27:1051-1056. p. DOI: http://dx.doi.org/10.1016/j.fm.2010.07.007

De Hoog G.S., Guarro J., Gené J., Figueras M.J. (2010): Atlas of Clinical Fungi. Második kiadás. Utrecht: ASM Press, CBS, 1126 p. ISBN: 9070351439

De Wit M., Osthoff G., Viljoen B.C., Hugo A. (2005): A comparative study of lipolysis and proteolysis in Cheddar cheese and yeast-inoculated Cheddar cheeses during ripening. Enzyme and Microbial Technology, 37:606-616. p. DOI: http://dx.doi.org/10.1016/j.enzmictec.2005.03.028

De Zeeuw JR, Tynan E.J. (1973a). Fermentation process for the production of D-mannitol. United States Patent 3,736,229.

De Zeeuw JR, Tynan E.J. (1973b). Fermentation process for the production of erythritol. United States Patent 3,756,917.

Deák T. and Beuchat L.R. (1987): Identification of foodborne yeasts. International Journal of Food Protection, 50:243-264. p.

Deák, T. and Beuchat, L. R. (1993) Comparison of the SIM, API 20C, and ID 32C Systems for Identification of Yeasts Isolated from Fruit Juice Concentrates and Beverages. Journal of Food Protection, 56:585-592. p.

Deák T. (1998): Az élesztők általános jellemzése. 33-60 p. In: Élesztőgombák. Budapest: Mezőgazdasági Szaktudás Kiadó. 243 p. ISBN: 9789633562536 
Deák T. (2006): Candida and related genera. 334-353 p. In: Blackburn C. (Szerk.): Food spoilage microorganisms. Cambridge: Woodhead Publishing Limited. 712 p. ISBN: 9781855739666

Deák T. (2008): Handbook of food spoilage yeasts. Második kiadás. Boca Raton: CRC Press. 325 p. ISBN: $978142004493-5$

Deetae P., Mounier J., Bonnarme P., Spinnler H.E., Irlinger F., Helinck S. (2009): Effects of Proteus vulgaris growth on the establishment of a cheese microbial communityand on the production of volatile aroma compounds in a model cheese. Journal of Applied Microbiology, 107:1404-1413. p. DOI: http://dx.doi.org/10.1111/j.1365$\underline{2672.2009 .04315 . x}$

Delbes-Paus C., Pochet S., Helinck S., Veisseire P., Bord C., Lebecque A., Coton M., Desmasures N., Coton E., Irlinger F., Montel M.-C. (2012): Impact of Gram negative bacteria in interaction with a complex microbial consortium on biogenic amine content and sensory characteristics of an uncooked pressed cheese. Food Microbiology, 30:74-82. p. DOI: $\underline{\text { http://dx.doi.org/10.1016/j.fm.2011.12.008 }}$

Diriye E.U., Scorzeiti G., Martini A. (1993): Methods for the separation of yeast cells from surfaces of processed, frozen foods. International Journal of Food Microbiology, 19:2737. p. DOI: http://dx.doi.org/10.1016/0168-1605(93)90121-V

Drake S.D., Evans J.B., Niven C.F. (1959): The identity of yeasts in the surface flora of packaged frankfurters. Journal of Food Science, 24 (3):243-246. p. DOI: 10.1111/j.1365$\underline{2621.1959 . t b 17268 . x}$

Encinas J.P., López-Diáz T.M., García-López M.L., Otero A., Moreno B. (2000): Yeast populations on Spanish fermented sausages. Meat Science, 54:203-208. p. DOI: http://dx.doi.org/10.1016/S0309-1740(99)00080-7

Fell J.W., Boekhout T., Fonseca A., Scorzetti G., Statzell-Tallman A. (2000): Biodiversity and systematics of basidiomycetous yeasts as determined by large-subunit rDNA D1/D2 domain sequence analysis. International Journal of Systematic and Evolutional Microbiology, 50:1351-1371. p. DOI: http://dx.doi.org/10.1099/00207713-50-3-1351 
Ferreira A.D., Viljoen B.C. (2003): Yeasts as adjunct starters in matured Cheddar cheese. International Journal of Food Microbiology, 86:131-140. p. DOI: http://dx.doi.org/10.1016/S0168-1605(03)00252-6

Fleet G.H. (1992): Spoilage yeasts. Critical Reviews in Biotechnology, 12:1-44. p. DOI: http://dx.doi.org/10.3109/07388559209069186

Fleet G. H. (2006): Saccharomyces and related genera. 306-335. p. In: Blackburn C. de W. (Szerk.): Food spoilage microorganisms. Cambridge: Woodhead Publishing Limited, 712 p. ISBN: 9781855739666

Fonseca Á., Scorzetti G., Fell J.W. (2000): Diversity in the yeast Cryptococcus albidus and related species as revealed by ribosomal DNA sequence analysis. Canadian Journal of Microbiology, 46:7-27. p. DOI: http://dx.doi.org/10.1139/w99-108

Fontes G.C., Amaral P.F., Nele M., Coelho M.A. (2010): Factorial design to optimize biosurfactant production by Yarrowia lipolytica. Journal of Biomedicine and Biotechnology, Article number: 821306, 2010:1-8 p. DOI: http://dx.doi.org/10.1155/2010/821306

Fournier P., Gaillardin C., Persuy M.A., Klootwijk J., Heerikhuizen H. (1986): Heterogeneity in the ribosomal family of the yeast Yarrowia lipolytica: genomic organization and segregation studies. Gene, 42:273-82. p. DOI: http://dx.doi.org/10.1016/0378$\underline{1119(86) 90231-3}$

Freitas A.C., Pintado A.E., Pintado M.E., Malcata F.X. (1999): Role of dominant microflora of Picante cheese on proteolysis and lipolysis. International Dairy Journal, 9:593-603. p. DOI: http://dx.doi.org/10.1016/S0958-6946(99)00129-6

Fröhlich-Wyder M.-T.. (2003). Yeasts in dairy products. 209-237. p. In: Boekhout T., Robert V. (Szerk.) Yeasts in food: beneficial and detrimental aspects. Boca Raton: CRC Press, 512 p. ISBN: 9781855737068

Fung D.Y., Liang C. (1990): Critical review of isolation, detection, and identification of yeasts from meat products. Critical Reviews in Food Science and Nutrition, 29:341-379. p. DOI: http://dx.doi.org/10.1080/10408399009527532 
Gadaga T.H., Mutukumira A.N., Narvhus J.A. (2000): Enumeration and identification of yeasts isolated from Zimbabwean traditional fermented milk. International Dairy Journal, 10:459-466. p. DOI: http://dx.doi.org/10.1016/S0958-6946(00)00070-4

Galán-Sánchez F., Garcia-Agudo L., Garcia-Martos P., Rodrigues-Iglesias M. (2014): Candida galli as a Cause of Tinea Unguium - Molecular Characterization of a Rare Clinical Fungal Entity. Mycopathologia, 178:303-330. p. DOI: http://dx.doi.org/10.1007/s11046-014-9789$\underline{6}$

Garcia E.E., Aguedo M., Gomes N., Choquet A., Belo I., Teixeira J.A., Belin J.M., Waché Y. (2009): Production of 3-hydroxy- $\gamma$-decalactone, the precursor of two decenolides with flavouring properties, by the yeast Yarrowia lipolytica. Journal of Molecular Catalysis BEnzymatic, 57:22-26. p. DOI: http://dx.doi.org/10.1016/j.molcatb.2008.06.010

Gardini F., Suzzi G., Lombardi A., Galgano F., Crudele M.A., Andrighetto C., Schirone M., Tofalo R. (2001): A survey of yeasts in traditional sausages of southern Italy. FEMS Yeast Research., 1:161-167. p. DOI: http://dx.doi.org/10.1016/S1567-1356(01)00024-1

Gardini F., Tofalo R., Belletti N., Iucci L., Suzzi G., Torriani S., Guerzoni M.E., Lanciotti R. (2006): Characterization of yeasts involved in the ripening of Pecorino Crotonese cheese. Food Microbiology, 23:641-648. p. DOI: http://dx.doi.org/10.1016/j.fm.2005.12.005

Geysens SCJ, Vervecken W. (2011). Yeast strains producing mammalian-like complex Nglycans. International Patent Application WO 2011/061629 A2.

Gori K., Cantor M.D., Jakobsen M., Jespersen L. (2010): Production of bread, cheese and meat. 3-27. p. In: Esser K. (Szerk.) The mycota, Industrial applications X. Berlin Heidelberg: Springer-Verlag, 508 p. ISBN: 978-3642074813

Groenewald M., Smith M.T., (2013): The teleomorph state of Candida deformans Langeron \& Guerra and description of Yarrowia yakushimensis comb. nov. Antonie van Leeuwenhoek, 103 (5):1023-1028. p. DOI: http://dx.doi.org/10.1007/s10482-013-9882-8

Groenewald M., Boekhout T., Neuvéglise C., Gaillardin C., van Dijck P.W.M., Wyss M. (2013): Yarrowia lipolytica: Safety assessment of an oleaginous yeast with a great industrial potential. Critical Reviews in Microbiology, 40 (3):187-206. p. DOI: http://dx.doi.org/10.3109/1040841X.2013.770386 
Guerzoni M.E., Lancotti R., Marchetti R. (1993): Survey of the physiological properties of the most frequent yeasts associated with commercial chilled foods. International Journal of Food Microbiology, 17:329-341. p. DOI: http://dx.doi.org/10.1016/0168-1605(93)90203-S

Hajósné Novák M. (1999): Genetikai variabilitás a növénynemesítésben: Molekuláris diagnosztika. Budapest: Mezőgazda Kiadó. 117 p. ISBN: 9789639121669

Hawksworth D.L., Crous P.W., Redhead A.S., Reynolds D.R., Samson R.A., Seifert K.A., Taylor J.W., Wingfield M.J. és 80 aláíró (2011): The Amsterdam Declaration on fungal nomenclature. Mycotaxon, 116:491-500. p. DOI: http://dx.doi.org/10.5248/116.491

Heretsch P., Thomas F., Aurich A., Krautscheid H., Sicker D., Giannis A. (2008): Syntheses with a chiral building block from the citric acid cycle: $(2 \mathrm{R}, 3 \mathrm{~S})$-isocitric acid by fermentation of sunflower oil. Angewandte Chemie-International Edition In English, 47:1958-1960. p. DOI: http://dx.doi.org/10.1002/anie.200705000

Holz M., Otto C., Kretzschmar A., Yovkova V., Aurich A., Pötter M., Marx A., Barth G. (2011): Overexpression of alphaketoglutarate dehydrogenase in Yarrowia lipolytica and its effect on production of organic acids. Applied Microbiology and Biotechnology, 89:1519-1526. p. DOI: $\underline{\text { http://dx.doi.org/10.1007/s00253-010-2957-9 }}$

Irlinger F., Yung S.A., Sarthou A.S., Delbés-Paus C., Montel M.C., Coton E., Coton M., Helinck S. (2012): Ecological and aromatic impact of two Gram-negative bacteria (Psychrobacter celer and Hafnia alvei) inoculated as part of the whole microbial community of an experimental smear soft cheese. International Journal of Food Microbiology, 153:332-338. p. DOI: http://dx.doi.org/10.1016/j.ijfoodmicro.2011.11.022

Ismail S.A.S., Deák T., Abd-Rahman H.A., Yassien M.A., Beuchat L.R. (2000): Presence and changes in populations of yeasts on raw and processed poultry products stored at refrigeration temperature. International Journal of Food Microbiology, 62:113-121. p. DOI: http://dx.doi.org/10.1016/S0168-1605(00)00414-1

Iucci L., Patrignani F., Belletti N., Ndagijimana M., Guerzoni M.E., Gardini F., Lanciotti R. (2007): Role of surface-inoculated Debaryomyces hansenii and Yarrowia lipolytica strains in dried fermented sausage manufacture. Part 2: evaluation of their effects on sensory quality and biogenic amine content. Meat Science, 75:669-675. p. DOI: http://dx.doi.org/10.1016/j.meatsci.2006.09.016 
Jain M.R., Zinjarde S.S., Deobagkar D.D., Deobagkar D.N. (2004): 2,4,6-Trinitrotoluene transformation by a tropical marine yeast, Yarrowia lipolytica NCIM 3589. Marine Pollution Bulletin, 49:783-788. p. DOI: http://dx.doi.org/10.1016/j.marpolbul.2004.06.007

Kamzolova S.V., Yusupova A.I., Vinokurova N.G., Fedotcheva N.I., Kondrashova M.N., Finogenova T.V., Morgunov I.G. (2009): Chemically assisted microbial production of succinic acid by the yeast Yarrowia lipolytica grown on ethanol. Applied Microbiology and Biotechnology, 83:1027-1034. p. DOI: http://dx.doi.org/10.1007/s00253-009-1948-1

Kamzolova S.V., Chiglintseva M.N., Lunina J.N., Morgunov I.G. (2012): $\alpha$-Ketoglutaric acid production by Yarrowia lipolytica and its regulation. Applied Microbiology and Biotechnology, 96:783-791. p. DOI: http://dx.doi.org/10.1007/s00253-012-4222-x

Karatay S.E., Donmez G. (2010): Improving the lipid accumulation properties of the yeast cells for biodiesel production using molasses. Bioresource Technology, 101:7988-7990. p. DOI: http://dx.doi.org/10.1016/j.biortech.2010.05.054

Katre G.K., Joshi C.J., Khot M.K., Zinjarde S., RaviKumar A. (2012): Evaluation of single cell oil (SCO) from a tropical marine yeast Yarrowia lipolytica NCIM 3589 as a potential feedstock for biodiesel. AMB Express, 2 (36):1-14. p. DOI: http://dx.doi.org/10.1186/2191$\underline{0855-2-36}$

Knutsen A.K., Robert V., Poot A., Epping W., Figge M., Holst-Jensen A., Skaar I., Smith M.Th. (2007): Polyphasic re-examination of Yarrowia lipolytica strains and the description of three novel Candida species: Candida oslonensis sp. nov., Candida alimentaria sp. nov. and Candida hollandica sp. nov. International Journal of Systematic and Evolutionary Microbiology, 57:2426-2435. p. DOI: http://dx.doi.org/10.1099/ijs.0.65200-0

Kobatake M., Kurata H. (1983): Determination of yeasts isolated from chilled household foods and raw seafoods. Food hygiene and safety science, 24:525-531. p.

Kurtzman C.P. (1998): Yarrowia van der Walt \& von Arx. 420-421. p. In: Kurtzman C.P., Fell J.W. (Szerk.) The yeasts, a taxonomic study. Negyedik kiadás. Amsterdam: Elsevier, 1076 p. ISBN: 9780444813121

Kurtzman C.P. (2005): New species and a new combination in the Hyphopichia and Yarrowia yeast clades. Antonie van Leeuwenhoek, International Journal of General and Molecular Microbiology, 88 (2):121-130. p. DOI: http://dx.doi.org/10.1007/s10482-005-2495-0 
Kurtzman C.P., Fell J.W. (2006): Yeast systematics and phylogeny-implications of molecular identification methods for studies in ecology. 11-30. p. In: Rosa C.A., Péter G. (Szerk.) Biodiversity and Ecophysiology of Yeasts. Berlin: Springer, 579 p. ISBN: 9783540309857

Kurtzman C.P., Fell, J.W., Boekhout T. (2011): The Yeasts, a Taxonomic Study. Ötödik kiadás. Amsterdam: Elsevier, 2080 p. ISBN: 9780444521491

Kurtzman C.P., Robnett C.J. (1994): Orders and families of ascosporogenous yeasts and yeastlike taxa compared from ribosomal RNA sequence similarities. 249-258. p. In: Hawksworth D.L. (Szerk.) Ascomycete systematics: problems and perspectives in the nineties. New York: Plenum Press, 453. p. ISBN: 9781475792904

Kurtzman C.P., Robnett C.J. (1995): Molecular relationships among hyphal ascomycetous yeasts and yeastlike taxa. Canadian Journal of Botany, 73:S824-830. p. DOI: http://dx.doi.org/10.1139/b95-328

Kurtzman C.P., Robnett C.J. (1998): Identification and phylogeny of ascomycetous yeasts from analysis of nuclear large subunit (26S) ribosomal DNA partial sequences. Antonie van Leeuwenhoek, 73:331-371. p. DOI: http://dx.doi.org/10.1023/A:1001761008817

Kurtzman C.P., Robnett C.J. (2013): Relationships Among Genera of the Saccharomycotyna (Ascomycota) from multigene phylogenetic analysis of type species. FEMS Yeast Research, 13:23-33. p. DOI: http://dx.doi.org/10.1111/1567-1364.12006

Lachance M.A., Daniel H.M., Meyer W., Prasad G.S., Gautam S.P., Boundy-Mills K. (2003): The D1/D2 domain of the large subunit rDNA of the yeast species Clavispora lusitaniae is unusually polymorphic. FEMS Yeast Research, 4:253-258 p.

Lachance M.A., Wijayanayaka T.M., Bundus J.D., Wijayanayaka D.N. (2011) Ribosomal DNA sequence polymorphism and the delineation of two ascosporic yeast species: Metschnikowia agaves and Starmerella bombicola. FEMS Yeast Research, 11:324-333. p.

Lanciotti R., Massa S., Guerzoni M.E., Di Fabio G. (1992): Light butter: natural microbial population and potential growth of Listeria monocytogenes and Yersinia enterocolitica. Letters in Applied Microbiology, 15:256-258. p. DOI: http://dx.doi.org/10.1111/j.1472765X.1992.tb00777.x 
Lanciotti R., Vannini L., Chaves Lopez C., Gobbetti M., Guerzoni M.E. (2005): Evaluation of the ability of Yarrowia lipolytica to impart strain-dependent characteristics to cheese when used as a ripening adjunct. International Journal of Dairy Technology, 58:89-99. p. DOI: http://dx.doi.org/10.1111/j.1471-0307.2005.00197.x

Larpin S., Mondoloni C., Goerges S., Vernoux J.-P., Guéguen M., Desmasures N. (2006): Geotrichum candidum dominates in yeast population dynamics in Livarot, a French redsmear cheese. FEMS Yeast Research, 6:1243-1253. p. DOI: http://dx.DOI.org/10.1111/j.1567-1364.2006.00127.x

Lelieveld H.L., Boon B., Bennett A., Brunius G., Cantley M., Chmiel A., Collins C.H., Crooy P., Doblhoff-Dier O., Economidis I., Elmqvist A., Frontali-Botti C., Havenaar R., Haymerlé H., Kappeli O., Leaver G., Lex M., Lund S., Mahler L., Marris R., Martinez J.L., Mosgaard Ch., Normand-Plessier C., Romantschuk M., Rudan F., Wagner K., Werner R.G. (1996): Safe biotechnology. 7. Classification of microorganisms on the basis of hazard. Applied Microbioly and Biotechnology, 45:723-729. p.

Leme F.C., de Barros Negreiros M.M., Koga F.A., de Moraes Gimenes Bosco S., Bagagli E., Haddad V. Jr. (2011): Evaluation of pathogenic fungi occurrence in traumatogenic structures of freshwater fish. Revista Da Sociedade Brasileira De Medicina Tropical, 44:182-185. p. DOI: http://dx.doi.org/10.1590/S0037-86822011005000007

Liang C. (1989): Rapid presumptive identification of yeasts in meat products, diplomamunka, Kansas State University, 24. p.

Limtong S., Youngmanitchai W., Kawasaki H., Seki T. (2008): Candida phangngensis sp. nov., an anamorphic yeast species in the Yarrowia clade, isolated from water in mangrove forests in Phang-Nga Province, Thailand. International Journal of Systematic and Evolutionary Microbiology, 58:515-519. p. DOI: http://dx.doi.org/10.1099/ijs.0.65506-0

Lin C.C.S., Fung D.Y.C. (1985): Effect of Dyes on the Growth of Food Yeasts. Journal of food science, 50 (1):241-244. p. DOI: http://dx.doi.org/10.1111/j.1365-2621.1985.tb13319.x

Linares D.M., Del Río B., Ladero V., Martínez N., Fernández M., Martín M.C., Álvarez M.A. (2012): Factors influencing biogenic amines accumulation in dairy products. Frontiers in Microbiology, 3 (180):1-10 p. DOI: http://dx.doi.org/10.3389/fmicb.2012.00180 
Liu S.Q., Tsao M. (2009): Enhancement of survival of probiotic and nonprobiotic lactic acid bacteria by yeasts in fermented milk under nonrefrigerated conditions. International $\begin{array}{lllll}\text { Journal of } & \text { Food }\end{array}$ http://dx.doi.org/10.1016/j.ijfoodmicro.2009.07.017

Liu S.-Q., Crow V.L. (2010): Production of dairy-based, natural sulphur flavor Cconcentrate by yeast fermentation. Food Biotechnology, 24 (1):62-77. p. DOI: http://dx.doi.org/10.1080/08905430903562724

Liu W.-C., Chan M.-C., Lin T.-Y., Hsu C.-H., Chiu S.-K. (2013): Candida lipolytica candidemia as a rare infectious complication of acute pancreatitis: A case report and literature review. Journal of Microbiology, Immunology and Infection, 46:393-396. p. DOI: http://dx.doi.org/10.1016/j.jmii.2013.04.007

Lodder J., Kreger-van Rij N.J.W. (1952): Characteristics and methods used in the classification. 6-35 p. In: Lodder, Kreger-van Rij N.J.W. (szerk.) The yeasts, a taxonomic study. Elsö kiadás. New York: Interscience, 713 p.

Lopandic K., Zelger S., Bánszky L.K., Eliskases-Lechner F., Prillinger H. (2006): Identification of yeasts associated with milk products using traditional and molecular techniques. Food Microbiology, 23:341-350. p. DOI: http://dx.doi.org/10.1016/j.fm.2005.05.001

López Del Castillo-Lozano M., Delile A., Spinnler H.E., Bonnarme P., Landaud S. (2007): Comparison of volatile sulphur compound production by cheese-ripening yeasts from methionine and methionine-cysteine mixtures. Applied Microbiology Biotechnology, 75:1447-1454. p. DOI: http://dx.doi.org/10.1007/s00253-007-0971-3

Lourens-Hattingh A., Viljoen B.C. (2002): Survival of dairy-associated yeasts in yoghurt and yoghurt-related products. Food Microbiology, 19:597-604. p. DOI: http://dx.doi.org/10.1006/fmic.2002.0515

Mann R., Rehm H.J. (1977): Degradation of aflatoxin B1 by various microorganisms. Zeitschrift Fur Lebensmittel-Untersuchung Und-Forschung, 163:39-43. p. DOI: http://dx.doi.org/10.1007/BF01123555

Margesin R., Schinner F. (1997): Effect of temperature on oil degradation by a psychrotrophic yeast in liquid culture and in soil. FEMS Microbiology Ecology, 24:243-249. p. DOI: http://dx.doi.org/10.1016/s0168-6496(97)00062-7 
Marquina D., Peres C., Caldas F.V., Marques J.F., Peinado J.M., Spencer-Martins I. (1992): Characterization of the yeast population in olive brines. Applied Microbiology, 14 (7):279283. p. DOI: http://dx.doi.org/10.1111/j.1472-765X.1992.tb00705.x

Martin N., Berger C., Le Du C., Spinnler H.E. (2001): Aroma compound production in cheese curd by coculturing with selected yeast and bacteria. Journal of Dairy Science, 84:21252135. p. DOI: http://dx.doi.org/10.3168/jds.S0022-0302(01)74657-7

Mayoral M.B., Martín R., Sanz A., Hernández P.E., González I., García T. (2005): Detection of Kluyveromyces marxianus and other spoilage yeasts in yoghurt using a PCR-culture technique. International Journal of Food Microbiology, 105:27-34. p. DOI: http://dx.doi.org/10.1016/j.ijfoodmicro.2005.06.006

McNeill, J., Barrie, F. R., Buck, W. R., Demoulin, V., Greuter, W., Hawksworth, D. L., Herendeen, P. S., Knapp, S., Marhold, K. et al. (2012): International Code of Nomenclature for algae, fungi, and plants (Melbourne Code). Koeltz Scientific Books. http://www.iapt-taxon.org/nomen/main.php ISBN: 9783874294256

Meyer S.A, Ahearn D.G, Yarrow D. (1984): Candida Berkhout. 585-849 p. In: Kreger-van Rij N.J.W. (Szerk.) The yeasts, a taxonomic study. Amsterdam: The Netherlands: Elsevier, harmadik kiadás. 1082 p. ISBN: 0444804218

Michely S., Gaillardin C., Nicaud J.-M., Neuvéglise C. (2013): Comparative Physiology of Oleaginous Species from the Yarrowia Clade. PLoS ONE, 8 (5):7. Article number: e63356 DOI: http://dx.doi.org/10.1371/journal.pone.0063356

Mirbagheri M., Nahvi I., Emtiazi G., Mafakher L., Darvishi F. (2012): Taxonomic Characterization and Potential Biotechnological Applications of Yarrowia lipolytica Isolated From Meat and Meat Products. Jundishapur Journal of Microbiology, 5(1):346351. p. DOI: http://dx.doi.org/10.5812/kowsar.20083645.2433

Mittal N., Dubey A.K. (2009): Microsatellite markers-A new practice of DNA based markers in molecular genetics. Pharmacognosy Reviews, 3:235-246. p.

Monnet C., Bleicher A., Neuhaus K., Sarthou A.S., Leclercq-Perlat M.-N., Irlinger F. (2010): Assessment of the antilisterial activity of microfloras from the surface of smear-ripened cheeses. Food Microbiology, 27:302-310. p. DOI: http://dx.doi.org/10.1016/j.fm.2009.11.009 
Nagy E., Niss M., Dlauchy D., Arneborg N., Nielsen D.S., Péter G. (2013): Yarrowia divulgata f.a., sp. nov., a yeast species from animal-related and marine sources. International Journal of Systematic and Evolutional Microbiology, 63:4818-4823. p. DOI: http://dx.doi.org/10.1099/ijs.0.057208-0

Nagy E., Dlauchy D., Medeiros A.O., Péter G., Rosa C.A. (2014): Yarrowia porcina sp. nov. and Yarrowia bubula f.a. sp. nov., two yeast species from meat and river sediment. Antonie van Leeuwenhoek, 105 (4):697-707. p. DOI: http://dx.doi.org/10.1007/s10482-014-0125-4

Nielsen D.S., Jacobsen T., Jespersen L., Koch A.G., Arneborg N. (2008): Occurrence and growth of yeasts in processed meat products: implications for potential spoilage. Meat Science, 80:919-926. p. DOI: http://dx.doi.org/10.1016/j.meatsci.2008.04.011

Oh E.-G., Park M.-Y., Chang D.-S. (1998): Proteolytic yeasts isolated from mackerel (Scomber japonicus). Korean Journal of Fisheries and Aquatic Sciences, 31:471-476. p.

Ordóñez J.A., Ordóñez E.M., Hierro J.M., de la Hoz B.L. (1999): Changes in the components of dry-fermented sausages during ripening. Critical Reviews in Food Science and Nutrition, 39 (4):329-367. p. DOI: http://dx.doi.org/:10.1080/10408699991279204

Otto C., Yovkova V., Barth G. (2011): Overproduction and secretion of $\alpha$-ketoglutaric acid by microorganisms. Applied Microbiology and Biotechnology, 92:689-695. p. DOI: http://dx.doi.org/10.1007/s00253-011-3597-4

Otto C., Yovkova V., Aurich A., Mauersberger S., Barth G. (2012): Variation of the by-product spectrum during $\alpha$-ketoglutaric acid production from raw glycerol by overexpression of fumarase and pyruvate carboxylase genes in Yarrowia lipolytica. Applied Microbiology and Biotechnology, 95:905-917. p. DOI: http://dx.doi.org/10.1007/s00253-012-4085-1

Ozturk I. (2015): Presence, changes and technological properties of yeast species during processing of pastirma, a Turkish dry cured meat product. Food Control, 50:76-84. p. DOI: http://dx.doi.org/10.1016/j.foodcont.2014.08.039

Palande A.S., Kulkarni S.V., León-Ramirez C., Campos-Góngora E., Ruiz-Herrera J., Deshpande M.V. (2014): Dimorphism and hydrocarbon metabolism in Yarrowia lipolytica var. indica. Archives of microbiology, $196 \quad$ (8):545-556. p. DOI: http://dx.doi.org/10.1007/s00203-014-0990-2 
Papanikolaou S., Aggelis G. (2011): Lipids of oleaginous yeasts. Part II: technology and potential applications. European Journal of Lipid Science and Technology, 113:1052-1073. p. DOI: http://dx.doi.org/10.1002/ejlt.201100015

Pariza M.W., Johnson E.A. (2001): Evaluating the safety of microbial enzyme preparations used in food processing: update for a new century. Regulatory Toxicology and Pharmacology, 33:173-186. p. DOI: http://dx.doi.org/10.1006/rtph.2001.1466

Patrignani F., Iucci L., Vallicelli M., Guerzoni M.E., Gardini F., Lanciotti R. (2007): Role of surface-inoculated Debaryomyces hansenii and Yarrowia lipolytica strains in dried fermented sausage manufacture. Part 1: evaluation of their effects on microbial evolution, lipolytic and proteolytic patterns. Meat Science, 75:676-686. p. DOI: http://dx.doi.org/10.1016/j.meatsci.2006.09.017

Patrignani F., Vannini L., Gardini F., Guerzoni M.E., Lanciotti R. (2011): Variability of the lipolytic activity and volatile molecules production by a strain of Yarrowia lipolytica in pork fat and its dependence on environmental conditions. Meat Science, 89:21-26. p. DOI: http://dx.doi.org/10.1016/j.meatsci.2011.03.015

Péter G., Deák T. (1991): On the false positive urease activity of Yarrowia lipolytica. Antonie van Leeuwenhoek, 60 (1):55-59. p. DOI: http://dx.doi.org/10.1007/BF00580442

Péter G., Dlauchy D., Vasdinyei R., Tornai-Lehoczki J., Deák T. (2004): Candida galli sp. nov., a new yeast from poultry. Antonie van Leeuwenhoek International Journal of General and Molecular Microbiology, 86:105-110. p. http://dx.doi.org/10.1023/B:ANTO.0000036117.03847.bd

Pitt J.I., Hocking A.D. (2009): Fresh and perishable foods. 383-400. p. In: Pitt J. I., Hocking A.D. (Szerk.) Fungi and food spoilage. Harmadik kiadás. London: Springer, 536 p. ISBN: 9780387922065

Praphailong W., Fleet G.H. (1997): The effect of pH, sodium chloride, sucrose, sorbate and benzoate on the growth of food spoilage yeasts. Food Microbiology, 14:459-468. p. DOI: http://dx.doi.org/10.1006/fmic.1997.0106

Ramírez-Castrillón M., Mendes S.D.C., Inostroza-Ponta M., Valente P. (2014): (GTG)5 MSPPCR Fingerprinting as a Technique for Discrimination of Wine Associated Yeasts? PLoS ONE 9 (8): e105870. DOI: http://dx.doi.org/doi:10.1371/journal.pone.0105870 
Ramos O., Santos A.C., Leao M.V., Pereira J.O., Silva S.I., Fernandes J.C., Franco M.I., Pintado M.E., Malcata F.X. (2012): Antimicrobial activity of edible coatings prepared from whey protein isolate and formulated with various antimicrobial agents. International Dairy Journal, 25:132-141. p. DOI: http://dx.doi.org/10.1016/j.idairyj.2012.02.008

Rodrigues G., Pais C. (2000): The influence of acetic and other weak carboxylic acids on growth and cellular death of the yeast Yarrowia lipolytica. Food Technology and Biotechnology, 38:27-32. p.

Rohm H., Lechner F. (1990): Evaluation and reliability of a simplified method for the identification of foodborne yeasts. Applied and Environmental Microbiology, 56:12901295.

Rohm H., Eliskases-Lechner F., Bräuer M. (1992): Diversity of yeasts in selected dairy products. Journal of Applied Bacteriology, 72:370-376. p. DOI: http://dx.doi.org/10.1111/j.1365$\underline{\text { 2672.1992.tb01848.x }}$

Romano P., Capece A., Jespersen L. (2006): Taxonomic and Ecological Diversity of Food and Beverage Yeasts. 13-54. p. In: Querol A., Fleet G. (szerk.) The Yeast Handbook Volume 2, Yeasts in Food and Beverages. Berlin Heidelberg: Springer-Verlag, 448 p. ISBN: 9783540283881

Roostita R., Fleet G.H. (1996): The occurrence and growth of yeasts in Camembert and blueveined cheeses. International Journal of Food Microbiology, 28:393-404. p. DOI: http://dx.doi.org/10.1016/0168-1605(95)00018-6

Ross H.M., Harden T.J., Nichol A.W., Deeth H.C. (2000): Isolation and investigation of microorganisms causing brown defects in mould ripened cheeses. Australian Journal of Dairy Technology, 55:5-8. p.

Rufino R.D., Luna J.M., Sarubbo L.A.,Rodrigues L.R.M., Teixeira J.A.C., Campos-Takaki G.M. (2011): Antimicrobial and antiadhesive potential of a biosurfactant Rufisan produced by Candida lipolytica UCP 0988. Colloids and Surfaces B-Biointerfaces, 84:1-5. p. DOI: http://dx.doi.org/10.1016/j.colsurfb.2010.10.045 
Rywinska A., Juszczyk P., Wojtatowicz M., Robak M., Lazar Z., Tomaszewska L., Rymowicz W. (2013): Glycerol as a promising substrate for Yarrowia lipolytica biotechnological applications. Biomass Bioenergy, 48:148-166. p. DOI: http://dx.doi.org/10.1016/j.biombioe.2012.11.021

Saiki R.K., Gelfand D.H., Stoffel S., Schaf S.J., Higuchi R., Hoprn G.T., Mullis K.B., Erlich H.A. (1988): Primer-directed enzymatic amplification of DNA with a thermostable DNA polymerase. Science, 239:487-491. p. DOI: http://dx.doi.org/10.1126/science.2448875

Samelis J., Sofos J.N. (2003): Yeasts in meat and meat products. 239-266. p. In: Boekhout T, Robert V. (Szerk.) Yeasts in Food. Boca Raton: CRC Press, 488 p. ISBN: 9781855737068

Samson R.A., van Kooij J.A., de Boer E. (1987): Microbiological quality of commercial tempeh in the Netherlands. Journal of Food Protection, 50:92-94. p.

Samson R.A., Hoekstra E.S., Frisvad J.C. (2004): Introduction to food- and airborne fungi, 7. kiadás. Utrecht: ASM Press, CBS, 389 p. ISBN: 9789070351526

Sancho T., Giménez-Jurado G., Malfeito-Ferreira M., Loureiro V. (2000): Zymological indicators: a new concept applied to the detection of potential spoilage yeast species associated with fruit pulps and concentrates. Food Microbiology, 17:613-624. p. DOI: http://dx.doi.org/10.1006/fmic.2000.0360

Schoch C.L., Seifert K.A., Huhndorf S., Robert V., Spouge J.L., Levesque C.A., Chen W., and Fungal Barcoding Consortium (2012): Nuclear ribosomal internal transcribed spacer (ITS) region as a universal DNA barcode marker for Fungi. Proceedings of the National Academy of Sciences, 1-6. p. DOI: http://dx.doi.org/10.1073/pnas.1117018109

Scorzetti G., Fell J.W., Fonseca A., Statzell-Tallman A. (2002): Systematics of basidiomycetous yeasts: a comparison of large subunit D1/D2 and internal transcribed spacer rDNA regions. FEMS Yeast Research, 2:495-517. p.

Selgas M.D., Ros J., Garcia M.L. (2003): Effect of selected yeast strains on the sensory properties of dry fermented sausages. European Food Research and Technology, 217:475480. p. DOI: http://dx.doi.org/10.1007/s00217-003-0778-0

Seiler H., Busse M. (1990): The yeasts of cheese brines. International Journal of Food Microbiology, 11:289-303. p.

Sharpe PL, Ye RW, Zhu QQ. (2008). Carotenoid production in a recombinant oleaginous yeast. International Patent Application WO 2008/073367 A1. 
Shinde N.R., Bankar A.V., Kumar A.R., Zinjarde S.S. (2012). Removal of Ni (II) ions from aqueous solutions by biosorption onto two strains of Yarrowia lipolytica. Journal of Environmental Management, 102:115-124. p. http://dx.doi.org/10.1016/j.jenvman.2012.02.026

Sinigaglia M., Lanciotti R., Guerzoni M.E. (1994): Biochemical and physiological characteristics of Yarrowia lipolytica strains in relation to isolation source. Canadian Journal of Microbiology, 40:54-59. p. DOI: http://dx.doi.org/10.1139/m94-008

Song H., Zhou L., Zhang L., Gao B., Wei D., Shen Y., Wang R., Madzak C., Jiang Z. (2011): Construction of a whole-cell catalyst displaying a fungal lipase for effective treatment of oily wastewaters. Journal of Molecular Catalysis B-Enzymatic, 71:166-170. p. DOI: http://dx.doi.org/10.1016/j.molcatb.2011.04.015

Spinnler H.E., Berger C., Lapadatescu C., Bonnarme P. (2001): Production of sulfur compounds by several yeasts of technological interest for cheese ripening. International Dairy Journal, 11:245-252. p. DOI: http://dx.doi.org/10.1016/S0958-6946(01)00054-1

Stratford M. (2006): Food and beverage spoilage yeasts. 335-380. p. In: Querol A., Fleet G.H., (Szerk.) The yeast handbook: yeasts in food and beverages. Berlin: Springer-Verlag, 448 p. DOI: http://dx.doi.org/10.1016/S0958-6946(01)00054-1

Strouhal M., Kizek R., Vacek J., Trnkova L., Nemec M. (2003): Electrochemical study of heavy metals and metallothionein in yeast Yarrowia lipolytica. Bioelectrochemistry, 60:29-36. p. DOI: http://dx.doi.org/10.1016/S1567-5394(03)00043-4

Suh S.-O., Zhou J.J. (2010): Methylotrophic yeasts near Ogataea (Hansenula) polymorpha: a proposal of Ogataea angusta comb.nov. and Candida parapolymorpha sp. nov. FEMS Yeast Research, 10:631-638. p. DOI: http://dx.doi.org/10.1111/j.1567-1364.2010.00634.x

Suzuki M., Suh S.-O., Sugita T., Nakase T. (1999): A phylogenetic study on galactosecontaining Candida species based on 18S ribosomal DNA sequences. The Journal of General and Applied Microbiology, 45:229-238. p.

Teofanova D., Hristov P., Yoveva A., Radoslavov G. (2012): Issues Associated with Genetic Diversity Studies of the Liver Fluke, Fasciola Heptica (Platyhelminthes, Digenea, Fasciolidae). 252-274. p. In: Caliskan M. (szerk.) Genetic diversity in microorganisms. Rijeka: InTech, 370 p. ISBN 9789535100645 
Tomaszewska L., Rywinska A., Gladkowski W. (2012): Production of erythritol and mannitol by Yarrowia lipolytica yeast in media containing glycerol. Journal of Industrial Microbiology and Biotechnology, 39:1333-1343. p. DOI: http://dx.doi.org/10.1007/s10295-012-1145-6

Trindade J.R., Freire M.G., Amaral P.F.F., Coelho M.A.Z., Coutinho J.A.P., Marrucho I.M. (2008): Aging mechanisms of oil-in-water emulsions based on a bioemulsifier produced by Yarrowia lipolytica. Colloids and Surface A-Physicochemical and Engineering Aspects, 324:149-154. p. DOI: http://dx.doi.org/10.1016/j.colsurfa.2008.04.009

Tsigie Y.A., Huynh L.H., Ahmed I.N., Ju Y.H. (2012): Maximizing biodiesel production from Yarrowia lipolytica Po1g biomass using subcritical water pretreatment. Bioresource Technology, 111:201-207. p. DOI: http://dx.doi.org/10.1016/j.biortech.2012.02.052

Turki S., Mrabet G., Jabloun Z., Destain J., Thonart P., Kallel H. (2010). A highly stable Yarrowia lipolytica lipase formulation for the treatment of pancreatic exocrine insufficiency. Biotechnology and Applied Biochemistry, 57:139-149. p. DOI: http://dx.doi.org/10.1042/BA20100272

Valente P., Ramos J.P., Leoncini O. (1999): Sequencing as a tool in yeast molecular taxonomy. Canadian Journal of Microbiology, 45:949-958. p. DOI: http://dx.doi.org/10.1139/w99$\underline{094}$

van den Tempel T., Jakobsen M. (1998): Yeasts associated with Danablu. International Dairy Journal, 8:25-31. p. DOI: http://dx.doi.org/10.1016/S0958-6946(98)00013-2

van den Tempel T., Jakobsen M. (2000): The technological characteristics of Debaryomyces hansenii and Yarrowia lipolytica and their potential as starter cultures for production of Danablu. International Dairy Journal, 10:263-270. p. DOI: http://dx.doi.org/10.1016/S0958-6946(00)00053-4

van der Walt J.P. (1970): Criteria and methods used in classification. In: Lodder J. (Szerk.) The yeasts, a taxonomyc study. Második kiadás. Amsterdam: North-Holland Publishing Company, 1385 p. ISBN: 0720440548

van der Walt J.P., Scott D.B. (1971): The yeast genus Saccharomycopsis Schiönning. Mycopathologia et Mycologia Applicata, 2604 (43):279-288. p.

van der Walt J.P., von Arx J.A. (1980): The yeast genus Yarrowia gen. nov. Antonie van Leeuwenhoek 46:517-521. p. 
van der Walt J.P., Yarrow D. (1984): Methods for the isolation, maintenance, classification and identification of yeasts. In: Kreger-van Rij N.J.W. (Szerk.) The yeasts, a taxonomyc study. Amsterdam: The Netherlands: Elsevier, harmadik kiadás. 1082 p. ISBN: 0444804218

van Uden N., Buckley H.R. (1970): Candida Berkhout. In: Lodder J. (Szerk.) The yeasts, a taxonomyc study. Second edition. Amsterdam: North-Holland Publishing Company, 8931087 p. ISBN: 9780720440546

Vandamme E.J., Soetaert W. (2002): Bioflavours and fragrances via fermentation and biocatalysis. Journal of Chemical Technology and Biotechnology, 77:1323-1332. p. DOI: http://dx.doi.org/10.1002/jctb.722

Vatsal A., Zinjarde S.S., Kumar A.R. (2011): Growth of a tropical marine yeast Yarrowia lipolytica NCIM 3589 on bromoalkanes: relevance of cell size and cell surface properties. Yeast, 28:721-732. p. DOI: http://dx.doi.org/10.1002/yea.1901

Viljoen B.C., Dykes G.A., Callis M., von Holy A. (1993): Yeasts associated with Vienna sausage packaging. International Journal of Food Microbiology, 18:53-62. p. DOI: http://dx.doi.org/10.1016/0168-1605(93)90007-4

Viljoen B.C., Geornaras I., Lamprecht A., von Holy A. (1998): Yeast populations associated with processed poultry. Food microbiology, 15:113-117. p. DOI: http://dx.doi.org/10.1006/fmic.1997.0137

Viljoen B.C., Lourens-Hattingh A., Ikalafeng B., Péter G. (2003): Temperature abuse initiating yeast growth in yoghurt. Food Research International, 36:193-197. p. DOI: http://dx.doi.org/10.1016/S0963-9969(02)00138-2

Viljoen B.C. (2006): Yeast Ecological Interactions. Yeast-Yeast, Yeast-Bacteria, Yeast-Fungi Interactions and Yeasts as Biocontrol Agents. 83-110. p. In: Amparo Q., Fleet G. (Szerk.) Yeasts in food and beverages. Berlin Heidelberg: Springer-Verlag, 453 p. ISBN: 9783540283980

von Arx J.A. (1972): On Endomyces, Endomycopsis and related yeast-like fungi. Antonie van Leeuwenhoek, 38:289-309 p.

Wang X.X., Chi Z., Ru S.G., Chi Z.M. (2012): Genetic surface-display of methyl parathion hydrolase on Yarrowia lipolytica for removal of methyl parathion in water. Biodegradation, 23:763-774. p. DOI: http://dx.doi.org/10.1007/s10532-012-9551-z 
Welthagen J.J., Viljoen B.C. (1998): Yeast profile in Gouda cheese during processing and ripening. International Journal of Food Microbiology, 41:185-194. p. DOI: http://dx.doi.org/10.1016/S0168-1605(98)00042-7

Westall S., Filtenborg O. (1998): Spoilage yeasts of decorated soft cheese packed in modified atmosphere. Food Microbiology, 15:243-249. p. http://dx.doi.org/10.1006/fmic.1997.0162

Wickerham L.J., Kurtzman C.P., Herman A.I. (1970): Sexual reproduction in Candida lipolytica. Science, 167:11-41.p.

Williams A.G., Withers S.E. (2007): Tyrosine metabolism in pigment-forming Yarrowia lipolytica strains isolated from English and European speciality mould-ripened cheese exhibiting a brown discolouration defect. International Journal of Dairy Technology 60:165-174. p. DOI: http://dx.doi.org/10.1111/j.1471-0307.2007.00334.x

Wolter H., Laing E., Viljoen B.C. (2000): Isolation and identification of yeasts associated with intermediate moisture meats. Food Technology and Biotechnology, 38:69-75. p.

Wyder M.-T., Bachmann H.-P., Puhan Z. (1999): Role of selected yeasts in cheese ripening: an evaluation in foil wrapped raclette cheese. Lebensmittel-Wissenschaft und Technology, 32:333-343. p. DOI: http://dx.doi.org/10.1006/fstl.1999.0555

Yamada Y., Nojiri M. Matsuyama M., Kondo K. (1976): Coenzyme Q system in the classification of the ascosporogenous yeast genera Debaryomyces, Saccharomyces, Kluyveromyces, and Endomycopsis. Journal of General and Applied Microbiology, 22:325-337. p. DOI: http://dx.doi.org/10.2323/jgam.22.325

Yarrow D. (1972): Four new combinations in Yeasts. Antonie van Leeuwenhoek, 38: 357-360. p.

Yarrow D. (1998): Methods for the isolation, maintenance and identification of yeasts. Kurtzman C. P., Fell J.W. (Szerk.) The yeasts, a taxonomyc study. Negyedik kiadás, 1055 p. ISBN: 9780444813121

Yu Z., Du G., Zhou J., Chen J. (2012): Enhanced a-ketoglutaric acid production in Yarrowia lipolytica WSH-Z06 by an improved integrated fed-batch strategy. Bioresource Technology, 114:597-602. p. DOI: http://dx.doi.org/10.1016/j.biortech.2012.03.021 
Yuzbashev T.V., Yuzbasheva E.Y., Laptev I.A., Sobolevskaya T.I., Vybornaya T.V., Larina A.S., Gvilava I.T., Antonova S.V., Sineoky S.P. (2011): Is it possible to produce succinic acid at a low pH? Bioengineered Bugs, 2:115-119. p. DOI: http://dx.doi.org/10.4161/bbug.2.2.14433

Zarowska B., Wojtatowicz M., Polomska X., Juszczyk P. Chrzanowska J. (2004): Factors affecting killer activity of some yeast species occurring in Rokpol cheese. Folia Microbiologica, 49:713-717. p. DOI: http://dx.doi.org/10.1007/BF02931554

Zhang B., Rong C., Chen H., Song Y., Zhang H., Chen W. (2012): De novo synthesis of trans10, cis-12 conjugated linoleic acid in oleaginous yeast Yarrowia lipolytica. Microbial Cell Factories, 11:51. p. DOI: http://dx.doi.org/10.1186/1475-2859-11-51

Zhou J., Yin X., Madzak C., Du G., Chen J. (2012): Enhanced $\alpha$-ketoglutarate production in Yarrowia lipolytica WSH-Z06 by alteration of the acetyl-CoA metabolism. Journal of Biotechnology, 161:257-264. p. DOI: http://dx.doi.org/10.1016/j.jbiotec.2012.05.025

$\underline{\text { Internet }}$

CBS adatbázis:

http://www.cbs.knaw.nl/Collections/Biolomics.aspx?Table=CBS\%20strain\%20database. 2014. 10. 01. 
DOI: 10.14267/phd.2015033 


\section{MELLÉKLETEK}

\section{M1. FELHASZNÁLT TÁPKÖZEGEK, OLDATOK ÖSSZETÉTELE}

\section{Az izolátumok fenntartásához használt ferdeagar}

2\%-os Malátakivonat agar (1 1 l)

$\begin{array}{ll}\text { Malátakivonat } & 20 \mathrm{~g} \\ \text { Agar } & 25 \mathrm{~g}\end{array}$

Dúsításhoz, izoláláshoz felhasznált tápközegek

Glükóz-pepton-élesztőkivonat agar (GPY, $\mathrm{pH}=7 ; 1$ l)

$\begin{array}{lc}\text { Glükóz } & 20 \mathrm{~g} \\ \text { Pepton } & 10 \mathrm{~g} \\ \text { Éleszetőkivonat } & 5 \mathrm{~g} \\ \text { Agar } & 20 \mathrm{~g}\end{array}$

Módosított Yarrowia dúsító leves (pH=3,5; 1 1)
Kálium-dihidrogén-foszfát
$34 \mathrm{~g}$
Yeast Nitrogen Base (Sigma, product no.:Y1250) 6,7 g
Foszforsav
3,5 pH eléréséig
Hexadekán
$5 \mathrm{ml}$ 
Rose Bengal Chloramphenicol (RBC, product no.: 1.00.467, $\mathrm{pH}=7,2 ; 1$ )

$$
\text { RBC portáptalaj (MERCK) 32,2 g }
$$

Yarrowia dúsító leves $(\mathrm{pH}=3,4-3,6 ; 1$ 1)

Yeast Carbon Base (Formedium, product no.: CYN0601) 6,7 g

Dinátrium-hidrogén-foszfát

Citromsav

Hexadekán
$9,142 \mathrm{~g}$

$13,026 \mathrm{~g}$

$5 \mathrm{ml}$

\section{Fiziológiai tesztekhez használt tápközegek}

Yeast Carbon Base (nitrogénforrás asszimilációhoz, 1 1)

Yeast Carbon Base (Formedium, product no.: CYN0601) 11,7 g
Agar
$20 \mathrm{~g}$

Cikloheximid rezisztencia vizsgálatához használt tápleves (1 1 l)

Yeast Nitrogen Base (Sigma, product no.:Y1250) $6,7 \mathrm{~g}$

Glükóz $5 \mathrm{~g}$

Cikloheximid $\quad 0,01$ és $0,1 \mathrm{w} / \mathrm{v}$ végkoncentrációig 
Custers-féle $\mathrm{CaCO}_{3}$ táptalaj (glïkózból való savképzés vizsgálatára, 1 l)

Glükóz

Kalcium-karbonát

Élesztőkivonat

Agar
$50 \mathrm{~g}$

$5 \mathrm{~g}$

$5 \mathrm{~g}$

$20 \mathrm{~g}$

Diazonium Blue B reagens $(15 \mathrm{ml})$

Diazonium Blue B só $\quad 15 \mathrm{mg}$

Tris-(hidroximetil)-aminometán puffer (0,25 M, pH=7) $15 \mathrm{ml}$

Ecetsavas (1\%) táptalaj (ecetsavtürés vizsgálatához, 100 ml)

Glükóz

Tripton

Élesztőkivonat

Agar

Jégecet
$10 \mathrm{~g}$

$1 \mathrm{~g}$

$1 \mathrm{~g}$

$2 \mathrm{~g}$

$1 \mathrm{ml}$ 
Nitrát agar $(\mathrm{pH}=6 ; 11)$

Yeast Carbon Base (Formedium, product no.: CYN0601) 1,6 g
Kálium-nitrát
$1,4 \mathrm{~g}$

Brómtimolkék (1,2\%-os alkoholos oldat) $10 \mathrm{ml}$
Agar
$20 \mathrm{~g}$

Glükóz-pepton-élesztőkivonat ferdeagar (GPY, 1 1)

$\begin{array}{lc}\text { Glükóz } & 20 \mathrm{~g} \\ \text { Pepton } & 10 \mathrm{~g} \\ \text { Éleszetőkivonat } & 5 \mathrm{~g} \\ \text { Agar } & 20 \mathrm{~g}\end{array}$

Keményítő képzésének vizsgálatához használt agar (1 l)

Glükóz $10 \mathrm{~g}$

Yeast Nitrogen Base (Sigma, product no.:Y1250) 6,7 g

Agar $\quad 15 \mathrm{~g}$

Keményítő képzésének vizsgálatához használt Lugol oldat (300 ml)

Jód

$1 \mathrm{~g}$

Kálium-jodát

$2 \mathrm{~g}$ 
Szénhidráterjesztő leves (7 ml-enként adagolva, bele Durham-cső; 11 1)

Tripton

Élesztőkivonat

Szénhidrát

Brómtimolkék indikátor (1,2\%-os etanolos oldatból) $10 \mathrm{ml}$
$5 \mathrm{~g}$

$5 \mathrm{~g}$

$20 \mathrm{~g}$

Yeast Nitrogen Base (szénforrás asszimilációhoz, 1 l)

Yeast Nitrogen Base (Sigma, product no.:Y1250) $6,7 \mathrm{~g}$

0,5 g glükózzal egyenértékü szénforrás

Urea bontás vizsgálatához használt tápleves $(\mathrm{pH}=6,8 ; 11)$

$\begin{array}{lc}\text { Élesztőkivonat } & 0,1 \mathrm{~g} \\ \text { Kálium-dihidrogén-foszfát } & 9,1 \mathrm{~g} \\ \text { Dinátrium-hidrogénfoszfát } & 9,5 \mathrm{~g} \\ \text { Fenolvörös } & 0,01 \mathrm{~g} \\ \text { Urea } & 20 \mathrm{~g}\end{array}$

Vitaminmentes tápleves (1 1 )

Vitamin-free Yeast Base (Difco, product no.: 621530) 16,7 g 
A Yarrowia csoport tagjainak élelmiszerek romlásához potenciálisan hozzáájáruló tulajdonságainak teszteléséhez használt tápközegek

Fehérjebontás (zselatinfolyósítás) vizsgálatához használt tápleves ( $\left.\begin{array}{ll}1 & 1\end{array}\right)$

$\begin{array}{ll}\text { Zselatin } & 100 \mathrm{~g} \\ \text { Glükóz } & 5 \mathrm{~g}\end{array}$

Yeast Nitrogen Base (Sigma, product no.:Y1250) 6,7 g

Olívaolajos agar (zsírbontás vizsgálatához, 1 1) (Gorodkowa agar 5\% olívaolajjal)

$\begin{array}{lc}\text { Glükóz } & 1 \mathrm{~g} \\ \text { Nátrium-klorid } & 5 \mathrm{~g} \\ \text { Pepton } & 10 \mathrm{~g} \\ \text { Agar } & 20 \mathrm{~g} \\ \text { Olívaolaj } & 50 \mathrm{ml}\end{array}$

Yarrowia lipolytica differenciáló táptalaj (pigmenttermelés vizsgálatához, $\mathrm{pH}=7,2 ; 1$ )

$\begin{array}{ll}\text { Pepton } & 5 \mathrm{~g} \\ \text { Élesztőkivonat } & 5 \mathrm{~g} \\ \text { L-tirozin } & 1,819 \mathrm{~g} \\ \mathrm{MnSO}_{4} \cdot 5 \mathrm{H}_{2} \mathrm{O} & 0,151 \mathrm{~g} \\ \text { Tejsav } & 4,504 \mathrm{~g} \\ \text { Agar } & 25 \mathrm{~g}\end{array}$


Spóráztatáshoz használt ferdeagarok

Acetát agar (Adams-féle élesztőspóráztatáshoz; 1 1)

Nátrium-acetát

Glükóz

Agar

Burgonya-dextróz agar (PDA; 11 1)

Burgonyakivonat

$300 \mathrm{~g}$

Glükóz

$20 \mathrm{~g}$

Agar

$15 \mathrm{~g}$
$14 \mathrm{~g}$

$0,4 \mathrm{~g}$

$20 \mathrm{~g}$

Élesztőkivonat-malátakivonat agar (YM; 11 )

Élesztőkivonat

Malátakivonat

Pepton

Glükóz

Agar

$\begin{array}{lc}\text { Élesztőkivonat } & 3 \mathrm{~g} \\ \text { Malátakivonat } & 3 \mathrm{~g} \\ \text { Pepton } & 5 \mathrm{~g} \\ \text { Glükóz } & 10 \mathrm{~g} \\ \text { Agar } & 20 \mathrm{~g}\end{array}$


Élesztőkivonat-szacharóz agar (YES; 1 l)

Élesztőkivonat

$20 \mathrm{~g}$

Szacharóz

$150 \mathrm{~g}$

$\mathrm{MgSO}_{4} * 7 \mathrm{H}_{2} \mathrm{O}$

$0,5 \mathrm{~g}$

Agar

$20 \mathrm{~g}$

Glükóz-pepton-élesztőkivonat agar (GPY；1 1)

Glükóz

Pepton

Élesztőkivonat

Agar
$20 \mathrm{~g}$

$10 \mathrm{~g}$

$5 \mathrm{~g}$

$20 \mathrm{~g}$

Módosított glükóz-pepton-élesztőkivonat agar (GPYA; 1 1)

Glükóz

Pepton

Élesztőkivonat

Agar
$10 \mathrm{~g}$

$10 \mathrm{~g}$

$3 \mathrm{~g}$

$20 \mathrm{~g}$ 
Nitrát agar $(\mathrm{pH}=6 ; 11)$

Yeast Carbon Base (Formedium, product no.: CYN0601) 1,6 g

Kálium-nitrát $\quad 1,4 \mathrm{~g}$

Brómtimolkék (1,2\%-os alkoholos oldat) $10 \mathrm{ml}$

Agar

$20 \mathrm{~g}$

Kukoricaliszt agar (CM; 11$)$

Kukoricaliszt

Agar

$2 \%$ malátakivonat agar $(\mathrm{MEA} ; 11)$

Malátakivonat

Agar

$20 \mathrm{~g}$

„Restricted Growth” agar (RG; 1 1)

Élesztőkivonat

$0,2 \mathrm{~g}$

Pepton

Glükóz

Agar

$20 \mathrm{~g}$ 
V8 agar $(\mathrm{pH}=6,8 ; 700 \mathrm{ml})$

Élesztőkivonat

Desztillált víz

V8 lé

Agar
$5 \mathrm{~g}$

$350 \mathrm{ml}$

$350 \mathrm{ml}$

$14 \mathrm{~g}$

“Spezieller Nährstoffarmer Agar'” (SNA; 1 1)

$\begin{array}{lc}\mathrm{KH}_{2} \mathrm{PO}_{4} & 1 \mathrm{~g} \\ \mathrm{KNO}_{3} & 1 \mathrm{~g} \\ \mathrm{MgSO}_{4} \cdot 7 \mathrm{H}_{2} \mathrm{O} & 0,5 \mathrm{~g} \\ \mathrm{KCl} & 0,5 \mathrm{~g}\end{array}$

Glükóz

$0,2 \mathrm{~g}$

Szacharóz

$0,2 \mathrm{~g}$

Agar

$20 \mathrm{~g}$

„Yeast-Carbon Base” agar (YCB; 1 1)

Yeast Carbon Base (Formedium, product no.: CYN0601)

$6,7 \mathrm{~g}$

Agar

$20 \mathrm{~g}$ 
„Yeast-Carbon Base” agar kiegészítve $0.01 \%$ ammónium-szulfáttal (YCBAS; 1 l)

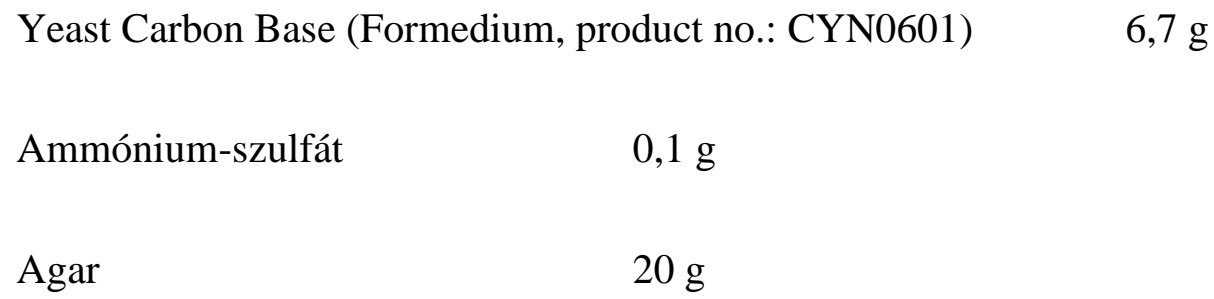

\section{Molekuláris vizsgálatokhoz felhasznált oldatok}

Agaróz gél (125 ml)

Agaróz $\quad 1,8 \mathrm{~g}$

10 X Tris-Bórsav-EDTA (TBE) puffer (1 1 l)

Tris base $108 \mathrm{~g}$
Bórsav $55 \mathrm{~g}$
EDTA (0,5 M-os, pH=8,5 törzsoldatból) $7,44 \mathrm{~g}$

Etídium-bromid törzsoldat $(1 \mathrm{ml})$

Etídium-bromid

$10,0 \mathrm{mg}$ 


\section{M2 ÁBRAJEGYZÉK}

1. ábra. A $Y$. lipolytica anyagcseréjének hatása természetes előfordulására, az élelmiszerek érésére és romlására. A ,>” (vízszintes és függőleges irányban) nagyobb gyakoriságot, legalábbis kimutatásának nagyobb gyakoriságát jelzi. Forrás: Groenewald et al. 2013.

2. ábra. A sejtmagi rDNS szakaszai. Az rRNS gének (rDNS) valamint az ITS és NTS szakaszok egymáshoz viszonyított elhelyezkedése a riboszómális géncsoportban (Deák 2008).

3. ábra. McIlvaine puffert tartalmazó dúsító táplevessel izolált élesztőgomba törzsek megoszlása hexadekán-asszimiláló képességük szerint (620 törzs)

4. ábra. Mcllvaine puffert tartalmazó dúsító táplevessel nyers húsból izolált élesztőgomba törzsek megoszlása hexadekán-asszimiláló képességük szerint (294 törzs)

5. ábra. McIlvaine puffert tartalmazó tartalmazó dúsító táplevessel nyers tejből és tejtermékekből izolált összes élesztőgomba törzs megoszlása hexadekán-asszimiláló képességük szerint (326 törzs)

6. ábra. McIlvaine puffert tartalmazó dúsító táplevessel izolált összes hexadekán-pozitív élesztőgomba törzs megoszlása aszerint, hogy a Yarrowia csoportba tartozik-e (256 törzs)

7. ábra. Nyers húsból McIlvaine puffert tartalmazó tartalmazó dúsító táplevessel izolált hexadekán-asszimiláló élesztőgomba törzsek megoszlása aszerint, hogy a Yarrowia csoportba tartoznak-e (159 törzs)

8. ábra. Nyers tejből és tejtermékekből McIlvaine puffert tartalmazó dúsító táplevessel izolált hexadekán- asszimiláló élesztőgomba törzsek megoszlása aszerint, hogy a Yarrowia csoportba tartoznak-e (97 törzs)

9. ábra. A Yarrowia-dúsító táplevesek összehasonlításához felhasznált mintákból izolált 206 törzs megoszlása

10. ábra. A Yarrowia-dúsító táplevesek összehasonlításához felhasznált nyers húsmintákból McIlvaine puffert tartalmazó dúsító táplevessel izolált 17 törzs megoszlása

11. ábra. A Yarrowia-dúsító táplevesek összehasonlításához felhasznált nyers húsmintákból foszfát puffert tartalmazó dúsító táplevessel izolált 11 törzs megoszlása

12. ábra. A Yarrowia-dúsító táplevesek összehasonlításához felhasznált túrómintákból McIlvaine puffert tartalmazó dúsító táplevessel izolált 92 élesztőgomba törzs megoszlása 
13. ábra. A Yarrowia-dúsító táplevesek összehasonlításához felhasznált túrómintákból foszfát puffert tartalmazó dúsító táplevessel izolált 86 élesztőgomba törzs megoszlása

14. ábra. Az összes izolált élesztőgomba törzs megoszlása

15. ábra. Nyers húsból izolált összes élesztőgomba törzs megoszlása

16. ábra. Tejtermékből izolált összes élesztőgomba törzs megoszlása

17. ábra. Nyers tejből izolált összes élesztőgomba törzs megoszlása

18. ábra. Túróból izolált összes élesztőgomba törzs megoszlása

19. ábra. Sajtból izolált összes élesztőgomba törzs megoszlása

20. ábra. A Yarrowia csoportba tartozó fajok típustörzseiből (GAC)5 primer felhasználásával felszaporított DNS fragmentumok gélelektroforézissel nyert mintázata.

21. ábra. A hét mikroszatellit csoportba tartozó törzsek és a Yarrowia csoport típustörzseiből $(\mathrm{GAC})_{5}$ primer felhasználásával felszaporított DNS fragmentumok gélelektroforézissel nyert mintázatai.

22. ábra. A Yarrowia divulgata f.a. és néhány rokon faj elhelyezkedését bemutató, azok ITS és az LSU rRNS gén D1/D2 régióinak összeillesztett szekvenciáin alapuló maximum-parsimony törzsfa. Lépték: 20 nukleotid szubsztitúció. Forrás: Nagy et al. 2013.

23. ábra. Yarrowia divulgata f.a. F6-17 ${ }^{\mathrm{T}}$ sarjadzó sejtjei 5\%-os malátakivonat agaron szaporítva 7 napig, $25{ }^{\circ} \mathrm{C}$-on, lépték $10 \mu \mathrm{m}$. Fáziskontraszt mikroszkópos felvétel. Forrás: Nagy et al. 2013.

24. ábra. Yarrowia divulgata f.a. $\mathrm{F} 6-17^{\mathrm{T}}$ valódi- és álhifái kukoricaliszt agar tárgylemeztenyészetben 7 nap $25^{\circ} \mathrm{C}$-on történő inkubáció után, lépték $10 \mu \mathrm{m}$. Fáziskontraszt mikroszkópos felvétel. Forrás: Nagy et al. 2013.

25. ábra. Yarrowia porcina és néhány közeli rokon faj (ITS) és az LSU rRNS gén D1/D2 régióinak összeillesztett szekvenciáin alapuló parsimony network analízisének eredménye. Minden összekötő vonal egy szubsztitúciót jelöl, a kis körök pedig egy-egy hiányzó közbülső szekvenciát. A téglalap az analízis által ősiként azonosított szekvenciákat jelöli. Forrás: Nagy et al. 2014.

26. ábra. A Yarrowia porcina és Yarrowia bubula, f.a. és rokon fajok elhelyezkedését bemutató, azok (ITS) és az LSU rRNS gén D1/D2 régióinak összeillesztett szekvenciáin alapuló maximum-parsimony törzsfa. Lépték: 20 bázis szubsztitúció. Forrás: Nagy et al. 2014. 
27. ábra. $(\mathrm{GTG})_{5}$ primerrel való sokszorosítással kapott fragmentek gélelektroforézisével előállított PCR ujjlenyomatok.

28. ábra. A Yarrowia porcina NCAIM Y. $02100^{\mathrm{T}}$ sarjadzó sejtjei, 5\% maláta kivonat agaron, 3 nap, $25{ }^{\circ} \mathrm{C}$-on történt inkubáció után, lépték $10 \mu \mathrm{m}$. Fáziskontraszt mikroszkópos felvétel. Forrás: Nagy et al. 2014.

29. ábra. Az NCAIM Y.02100 ${ }^{\mathrm{T}}$ és UFMG-RD131 ${ }^{\mathrm{A}}$ Yarrowia porcina törzsek aszkosporulációja, YES agaron, $25^{\circ} \mathrm{C}$-on, 7 nap után. Lépték $10 \mu \mathrm{m}$. A kép középső részén és jobb szélén szereplő nyilak a tokanyagba ágyazott, kiszabadult aszkospórákat mutatják. Fáziskontraszt mikroszkópos felvétel. Forrás: Nagy et al. 2014.

30. ábra. A Yarrowia bubula f.a. NCAIM Y.01998 ${ }^{\mathrm{T}}$ sarjadzó sejtjei, $5 \%$ maláta kivonat agaron, 3 nap, $25{ }^{\circ} \mathrm{C}$-on történt inkubáció után, lépték $10 \mu \mathrm{m}$. Fáziskontraszt mikroszkópos felvétel. Forrás: Nagy et al. 2014.

31. ábra. Néhány nyers húsból izolált Yarrowia csoportba tartozó törzsből (GAC)5 primer felhasználásával felszaporított DNS fragmentumok gélelektroforézissel nyert mintázata.

32. ábra. Néhány nyers tejből és tejtermékekből izolált törzsből (GAC)5 primer felhasználásával felszaporított DNS fragmentumok gélelektroforézissel nyert mintázata.

33. ábra. A nyers húsból izolált Yarrowia csoportba tartozó törzsek megoszlása (135 törzs 66 mintából)

34. ábra. A tejből és tejtermékekből Yarrowia csoporthoz tartozó törzsek megoszlása (84 törzs 67 mintából)

35. ábra. Az összes izolált Yarrowia csoportba tartozó törzs megoszlása (219 törzs 133 mintából)

36. ábra. Pigment termelő képesség vizsgálatához negatív kontrolként használt Saccharomyces cerevisiae NCAIM Y.00801 ${ }^{\mathrm{T}}$ törzs

37. ábra. C. alimentaria $\mathrm{CBS} 10151^{\mathrm{T}}$ pigment termelése

38. ábra. C. galli NCAIM Y. $1482^{\mathrm{T}}$ pigment termelése

39. ábra. C. hispaniensis NRRL4-5580 ${ }^{\mathrm{T}}$ pigment termelése

40. ábra. $C$. hollandica $\mathrm{CBS} 4855^{\mathrm{T}}$ pigment termelése

41. ábra. C. oslonensis CBS $10146^{\mathrm{T}}$ pigment termelése

42. ábra. $C$. phangngensis $\mathrm{CBS} 10407^{\mathrm{T}}$ pigment termelése 
43. ábra. Y. bubula NCAIM Y. $01998^{\mathrm{T}}$ pigment termelése

44. ábra. $Y$. deformans NCAIM Y.02005 ${ }^{\mathrm{T}}$ pigment termelése

45. ábra. $Y$. divulgata $\mathrm{F} 6-17^{\mathrm{T}}$ pigment termelése

46. ábra. Y. keelungensis $\mathrm{CBS} 11062^{\mathrm{T}}$ pigment termelése

47. ábra. Y. lipolytica NCAIM Y.0591 ${ }^{\mathrm{T}}$ pigment termelése

48. ábra. $Y$. porcina NCAIM Y $.02100^{\mathrm{T}}$ pigment termelése

49.ábra. Y. yakushimensis JCM $12782^{\mathrm{T}}$ pigment termelése

50. ábra. A zsírbontó képesség vizsgálatához negatív kontrolként használt S. cerevisiae NCAIM Y.00801 ${ }^{\mathrm{T}}$ törzs

51. ábra. C. alimentaria $\mathrm{CBS} 10151^{\mathrm{T}}$ zsírbontó képességének mértékét jelző kék elszíneződés

52. ábra. C. galli NCAIM Y. $01482^{\mathrm{T}}$ zsírbontó képességének mértékét jelző kék elszíneződés

53. ábra. C. hispaniensis NRRL4-5580 ${ }^{\mathrm{T}}$ zsírbontó képességének mértékét jelző kék elszíneződés

54. ábra. $C$. hollandica $\mathrm{CBS} 4855^{\mathrm{T}}$ zsírbontó képességének mértékét jelző kék elszíneződés

55. ábra. C. oslonensis CBS $10146^{\mathrm{T}}$ zsírbontó képességének mértékét jelző kék elszíneződés

56. ábra. $C$. phangngensis $\mathrm{CBS} 10407^{\mathrm{T}}$ zsírbontó képességének mértékét jelző kék elszíneződés

57. ábra. Y. bubula NCAIM Y.01998 ${ }^{\mathrm{T}}$ zsírbontó képességének mértékét jelző kék elszíneződés

58. ábra. Y. deformans NCAIM Y.02005 ${ }^{\mathrm{T}}$ zsírbontó képességének mértékét jelző kék elszíneződés

59. ábra. $Y$. divulgata $\mathrm{F} 6-17^{\mathrm{T}}$ zsírbontó képességének mértékét jelző kék elszíneződés

60. ábra. Y. keelungensis CBS $11062^{\mathrm{T}}$ zsírbontó képességének mértékét jelző kék elszíneződés

61. ábra. $Y$. lipolytica NCAIM Y.00591 ${ }^{\mathrm{T}}$ zsírbontó képességének mértékét jelző kék elszíneződés

62. ábra. Y. porcina NCAIM Y $.02100^{\mathrm{T}}$ zsírbontó képességének mértékét jelző kék elszíneződés 63.ábra. $Y$. yakushimensis JCM $12782^{\mathrm{T}}$ zsírbontó képességének mértékét jelző kék elszíneződés 64. ábra. A Y. porcina tokanyagba ágyazott aszkospórái szabadon és aszkuszban. Fáziskontraszt mikroszkópos felvétel. 
65. ábra. Az NCAIM Y.02100 ${ }^{\mathrm{T}}$ és UFMG-RD131 ${ }^{\mathrm{A}}$ Yarrowia porcina törzsek csírázó aszkospórja YES agaron, $25^{\circ} \mathrm{C}$-on, 143 nap után. Lépték $10 \mu \mathrm{m}$. Fáziskontraszt mikroszkópos felvétel. Forrás: Nagy et al. 2014.

66. ábra. Hexadekán-pozitív élesztőgombák megoszlása a vizsgált élelmiszerekben (394 törzs).

67. ábra. Hexadekán-pozitív élesztőgombák megoszlása nyers húsban (179 törzs).

68. ábra. Hexadekán-pozitív élesztőgombák megoszlása tejtermékekben (214 törzs).

69. ábra. Hexadekán-pozitív élesztőgombák megoszlása nyers tejben (43 törzs).

70. ábra. Hexadekán-pozitív élesztőgombák megoszlása túróban (136 törzs).

71. ábra. Hexadekán-pozitív élesztőgombák megoszlása sajtban (35 törzs).

72. ábra. Élesztőgombák megoszlása a vizsgált élelmiszerekben (826 törzs).

73. ábra. Élesztőgombák megoszlása nyers húsban (321 törzs).

74. ábra. Élesztőgombák megoszlása tejtermékekben (505 törus).

75. ábra. Élesztőgombák megoszlása nyers tejben (218 törzs).

76. ábra. Élesztőgombák megoszlása nyers túróban (230 törzs).

77. ábra. Élesztőgombák megoszlása nyers sajtban (57 törzs). 


\section{M3 TÁBLÁZATJEGYZÉK}

1. táblázat. Felhasznált élelmiszerminták és a belőlük izolált, vizsgált élesztőgombák száma

2. táblázat. A Yarrowia csoportba tartozó vizsgált referenciatörzsek

3. táblázat. PCR-hez használt primerek

4. táblázat. A Yarrowia csoport tagjainak nitrát asszimilációjának, glükóz erjesztésének és API ID32C teszttel vizsgálható fiziológiai tulajdonságainak összefoglaló táblázata (nem tartalmazza a kutatás e szakaszában még leíratlan fajokra vonatkozó adatokat)

5. táblázat. A Yarrowia csoport fajainak fiziológiai tulajdonságai

6. táblázat. A felhasznált élelmiszermintákból az új izolálási módszerrel izolált élesztőgombák száma

7. táblázat. A Yarrowia-dúsító táplevesek összehasonlításához felhasznált nyers húsmintákból McIlvaine puffert (1. dúsító) és foszfát puffert (2. dúsító) tartalmazó tápleves felhasználásával izolált törzsek megoszlása

8. táblázat. A Yarrowia-dúsító táplevesek összehasonlításához felhasznált túrómintákból McIlvaine puffert (1. dúsító) és foszfát puffert (2. dúsító) tartalmazó tápleves felhasználásával izolált törzsek megoszlása

9. táblázat. Egyes élelmiszercsoportokból izolált törzsek száma

10. táblázat. Az egyes csoportokba sorolt törzsek száma

11. táblázat. A Yarrowia divulgata f.a. leírásához figyelembe vett törzsek. Hullámos vonallal jelöltem az általam izolált törzset. Forrás: Nagy et al. 2013.

12. táblázat. A Yarrowia csoport típustörzseinek fehérjebontó-képessége 
DOI: 10.14267/phd.2015033 


\section{PUBLIKÁCIÓS LISTA}

\section{Szakcikk nemzetközi, impakt faktorral rendelkező folyóiratban}

Nagy E., Niss M., Dlauchy D., Arneborg N., Nielsen D.S., Péter G. (2013): Yarrowia divulgata f.a., sp. nov., a yeast species from animal-related and marine sources. International Journal of Systematic and Evolutional Microbiology, 63:4818-4823. p. DOI: http://dx.doi.org/10.1099/ijs.0.057208-0 $\underline{\mathbf{I F = 2 , 7 9 8 ~ ( 2 0 1 3 )}}$

Nagy E., Dlauchy D., Medeiros A.O., Péter G., Rosa C.A. (2014): Yarrowia porcina sp. nov. and Yarrowia bubula f.a. sp. nov., two yeast species from meat and river sediment. Antonie van Leeuwenhoek, 105 (4):697-707. p. DOI: http://dx.doi.org/10.1007/s10482-014-0125-4 $\underline{\mathrm{IF}=1,806(2014)}$

Nagy E.Sz. (2014): Isolation and diversity of food spoilage Yarrowia yeast strains from meat. $\begin{array}{llllll}\text { Acta } & \text { alimentaria, } & \text { (Suppl), } & \text { 101-106. } & \text { D. }\end{array}$ http://dx.doi.org/10.1556/AAlim.43.2014.Suppl.15 $\underline{\text { IF=0,274 (2014) }}$

\section{Szakcikk nemzetközi folyóiratban}

Nagy E.Sz. (2014): Differentiation of food spoilage yeast strains of the Yarrowia group by microsatellite polymerase chain reaction fingerprinting. Journal of Universal Sciences Online, 1(1): 6-11. p. DOI: http://dx.doi.org/10.17202/JUSO.2014.1.6

\section{Magyar nyelvü összefoglaló}

Nagy E., Péter G. (2012): Élelmiszerromlást okozó Yarrowia lipolytica komplex csoport törzseinek szelektív izolálása. Mikológiai Közlemények Clusiana Vol.51. No.1. V. Magyar Mikológiai Konferencia, május 24-26, 2012, Budapest, Magyarország. Abstr. pp. 154.

Nagy E. (2013): Yarrowia törzsek izolálása húsokról és rendszertani azonosításuk. II. Interdisciplinary Doctoral Conference, május 15-17, 2013, Pécs, Magyarország. Abstr. pp. 254. 


\section{$\underline{\text { Nemzetközi konferencia összefoglaló }}$}

Nagy E., Tornai-Lehoczki J., Péter G. (2012): The occurrence of the food spoilage yeast Yarrowia lipolytica and related yeast species in meat and raw milk in Hungary. $5^{\text {th }}$ Croatian Congress of Microbiology with International Participation, September 26-30, 2012, Primosten, Croatia. Abstr. pp. 90.

Nagy E., Tornai-Lehoczki J., Péter G., Dlauchy D. (2013): Food spoilage potential of the members of Yarrowia clade. Microbial Spoilers In Food, July 1-3, 2013, Quimper, France. Abstr. pp. 26.

Tornai-Lehoczki J., Péter G., Dlauchy D., Schvéder E., Sebő J. Nagy E. (2013): Diversity of filamentous fungi on various kinds of tea leaves and brewed tea drinks. Microbial Spoilers In Food, July 1-3, 2013, Quimper, France. Abstr. pp. 37.

Nagy E.Sz. (2013): Isolation, identification and diversity of food spoilage Yarrowia yeast strains from different foods. Food Science Conference, November 7-8, 2013, Budapest, Hungary. Abstr. pp. 53.

\section{Hazai konferencia teljes anyag}

Nagy E.Sz. (2013): Yarrowia törzsek izolálása húsokról és rendszertani azonosításuk. II. Interdisciplinary Doctoral Conference, May 15-17, 2013, Pécs, Hungary. Conference book pp. 427-434. 


\section{KÖSZÖNETNYILVÁNÍTÁS}

Ezúton is szeretném hálásan megköszönni Dr. Péter Gábornak, témavezetőmnek, hogy a kísérleteim elvégzéséhez, a doktori képzés követelményeinek teljesítéséhez, szakmai fejlődésemhez minden feltételt biztosított, útmutatásával, tanácsaival terelgette munkámat. Tiszteletreméltó tudásáért, emberségéért felnézek rá, kísérleteim során akár csak két szóval is nagy motivációt tudott adni. Az élesztőgombák iránti lelkesedése tovább fokozta az én lelkesedésemet is, így mindig örömmel kezdhettem egy-egy újabb ötlet megvalósításába.

Köszönettel tartozok Dr. Dlauchy Dénesnek a molekuláris biológiai kísérletekben nyújtott segítségéért, és, hogy tanácsaival, kifogyhatatlan ötleteivel segített a felmerülő problémák megoldásában, humorával könnyebbé tette az akadályok leküzdését.

Köszönetemet szeretném kifejezni Lehoczkiné Dr. Tornai Juditnak, aki szintén hozzájárult a képzés sikeres teljesítéséhez, sokat köszönhetek neki nem csak szakmai téren, hanem az élet más területein is. Köszönöm az évek során nyújtott támogatását, segítségét.

Hálás vagyok Kárpáti Erikának és Bétéri Gyuláné Katalinnak, akik technikai segítségükkel hozzájárultak a kísérleteim elvégzéséhez.

Nagyon hálás vagyok a Mezőgazdasági és Ipari Mikroorganizmusok Nemzeti Gyüjteménye dolgozóinak tanácsaikért, biztatásukért, türelmükért, és, hogy gondolkodás nélkül segítséget nyújtottak, bármiről is volt szó. Széppé tették a náluk töltött éveket, mindig hálával és szeretettel fogok rájuk gondolni.

Köszönettel tartozom a Sör- és Szeszipari Tanszéknek, elsősorban Hegyesné Dr. Vecseri Beáta Dékán Asszonynak és Dr. Nguyen Duc Quang Professzor Úrnak, amiért hozzájárultak, hogy alkalmanként a képzés lejárta utáni időszakban is átmehessek a Törzsgyüjteményhez, ezzel lehetővé téve kutatásom teljes lezárulását.

Köszönet Szöllősi Attilának és doktorandusz társaimnak, akik ötleteikkel, véleményükkel segítettek a dolgozat elkészítésében. 